Environmental Restoration Division ORNL Environmental Restoration Program

\title{
Groundwater Quality Monitoring Well Installation for Waste Area Grouping at Oak Ridge National Laboratory, Oak Ridge, Tennessee
}

\author{
J. A. Mortimore \\ T. A. Lee
}

Date Issued-September 1994

\section{Prepared for}

U.S. Department of Energy

Office of Environmental Restoration and Waste Management under budget and reporting code EW 20

Environmental Restoration and Waste Management Programs

Oak Ridge National Laboratory

Oak Ridge, Tennessee 37831-6285

managed by

MARTIN MARIETTA ENERGY SYSTEMS, INC.

for the

U.S. DEPARTMENT OF ENERGY

under contract DE-AC05-84OR21400 


\section{Author Affiliations}

J. A. Mortimore is staff project manager with the Environmental Restoration Program, Oak Ridge National Laboratory, Martin Marietta Energy Systems, Incorporated. T. A. Lee is a hydrogeologist with Ogden Environmental and Energy Services Co., Inc. (formally ERC Environmental and Energy Services Company). 


\section{DISCLAIMER}

This report was prepared as an account of work sponsored by an agency of the United States Government. Neither the United States Government nor any agency thereof, nor any of their employees, make any warranty, express or implied, or assumes any legal liability or responsibility for the accuracy, completeness, or usefulness of any information, apparatus, product, or process disclosed, or represents that its use would not infringe privately owned rights. Reference herein to any specific commercial product, process, or service by trade name, trademark, manufacturer, or otherwise does not necessarily constitute or imply its endorsement, recommendation, or favoring by the United States Government or any agency thereof. The views and opinions of authors expressed herein do not necessarily state or reflect those of the United States Government or any agency thereof. 


\section{DISCLAIMER}

Portions of this document may be illegible in electronic image products. Images are produced from the best available original document. 


\section{CONTENTS}

EXECUTIVE SUMMARY $\ldots \ldots \ldots \ldots \ldots \ldots \ldots \ldots \ldots \ldots \ldots \ldots \ldots$

1. INTRODUCTION $\ldots \ldots \ldots \ldots \ldots \ldots \ldots \ldots \ldots \ldots \ldots \ldots \ldots \ldots \ldots \ldots$

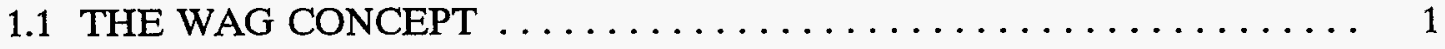

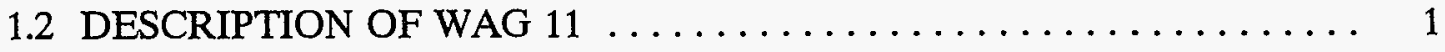

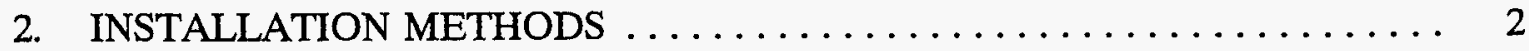

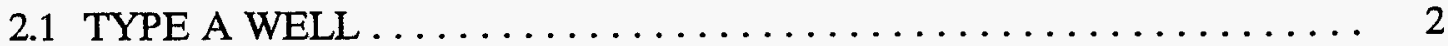

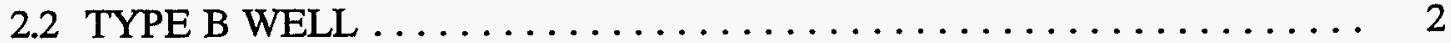

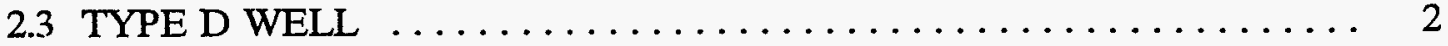

3. ENVIRONMENTAL, HEALTH, AND SAFETY REQUIREMENTS $\ldots \ldots \ldots$

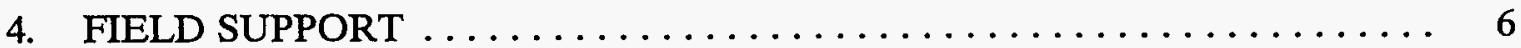

5. DRILLING RECORDS $\ldots \ldots \ldots \ldots \ldots \ldots \ldots \ldots \ldots \ldots \ldots \ldots$

6. WELL DEVELOPMENT $\ldots \ldots \ldots \ldots \ldots \ldots \ldots \ldots \ldots \ldots \ldots \ldots$

7. SAMPLING DURING INSTALLATION $\ldots \ldots \ldots \ldots \ldots \ldots \ldots$

8. SPECIAL NOTES ON INSTALLATION AND DEVELOPMENT $\ldots \ldots \ldots \ldots 10$

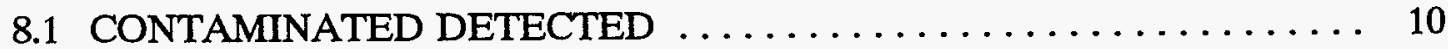

8.2 DEVIATIONS FROM THE SPECIFICATIONS $\ldots \ldots \ldots \ldots \ldots \ldots \ldots . \ldots$

8.3 HYDRAULIC FLUID SPILLS $\ldots \ldots \ldots \ldots \ldots \ldots \ldots \ldots \ldots \ldots \ldots \ldots \ldots$

REFERENCES $\ldots \ldots \ldots \ldots \ldots \ldots \ldots \ldots \ldots \ldots \ldots \ldots \ldots \ldots \ldots \ldots \ldots$

Appendix A-Data Packages $\ldots \ldots \ldots \ldots \ldots \ldots \ldots \ldots \ldots \ldots \ldots \ldots \ldots \ldots \ldots \ldots \ldots$

Appendix B-Operating Instructions for Handling Water and Cuttings from Well Drilling and Development of Groundwater Quality

Monitoring Wells 



\section{EXECUTIVE SUMMARY}

This report documents the drilling and installation of 18 groundwater quality monitoring (GQM) wells on the perimeter of Waste Area Grouping (WAG) 11. WAG 11 (White Wing Scrap Yard) is located on the west end of East Fork Ridge between White Wing Road and the Oak Ridge Turnpike. The scrap yard is approximately 25 acres in size. The wells at WAG 11 were drilled and developed between January 1990 and October 1990 . These wells were installed to characterize and assess the WAG in accordance with applicable Department of Energy, state, and Environmental Protection Agency regulatory requirements.

Well design and placement were performed by Martin Marietta Energy Systems, Inc. (Energy Systems) geologic staff and their subcontractors. The wells were drilled, installed, and developed by the subcontractor (Geotek Engineering, Inc.) under contract with Energy Systems. The contract was administered by the Energy Systems Engineering Division for the Environmental Restoration (ER) Program. Hydrogeologic support was provided by an environmental subcontractor [ERC Environmental and Energy Services, Inc. (ERCE)] under contract with Energy Systems. (As of January 1, 1992, ERCE started operating under the name of Ogden Environmental and Energy Services Co., Inc.) This contract was administered by ER Division staff. Radiation protection and industrial hygiene support for the drilling program were provided by Energy Systems staff or their subcontractors.

The wells at WAG 11 were drilled with auger or air rotary rigs. Depending on the hydrogeologic conditions present at each proposed well location, one of four basic installation methods was utilized. Detailed procedures for well construction were specified by the Engineering Division to ensure that the wells would provide water samples representative of the aquifer. To ensure conformance with the specifications, Energy Systems Construction Engineering and ERCE provided continuous oversight of field activities.

The purpose of the well installation program was to install GQM wells for groundwater characterization at WAG 11. Data packages produced during installation activities by the ERCE hydrogeologists are an important product of the program. These packages document the well drilling, installation, and development activities and provide valuable data for well sampling and WAG characterization. The forms contained in the packages include predrilling and postdrilling checklists, drilling and construction logs, development and hydraulic conductivity records, and quality control-related documents. 


\section{INTRODUCTION}

The purpose of this report is to document the drilling and installation of the groundwater quality monitoring (GQM) wells on the perimeter of Waste Area Grouping (WAG) 11. Installation of GQM wells was required at Oak Ridge National Laboratory (ORNL) for regulatory compliance. Data obtained from these wells will be used to characterize and assess groundwater quality at the perimeter of each WAG in accordance with applicable Department of Energy, state, and Environmental Protection Agency regulatory requirements. The wells in WAG 11 were drilled and developed from January 1990 to October 1990.

\subsection{THE WAG CONCEPT}

At ORNL, the solid waste management units (SWMUs) include solid waste storage areas (SWSAs), pipelines, spill sites, buildings, ponds, and experimental test sites that are considered to be potential sources of contamination. The SWMUs are further grouped into WAGs, the boundaries of which are defined by watersheds that contain contaminants derived from similar assemblages of operating facilities and SWMUs. Basically, the wells are located on or near these boundaries to determine whether contaminants have been released from the WAGs.

\subsection{DESCRIPTION OF WAG 11}

WAG 11 (White Wing Scrap Yard) is located on the west end of East Fork Ridge between White Wing Road and the Oak Ridge Turnpike [Fig. 1, map pocket (MMES map \#C3E20004A123, Rev. 0)]. The scrap yard is approximately 25 acres in size.

This area was first used in the early 1950 s for aboveground storage of contaminated material from the Oak Ridge National Laboratory (ORNL), the Oak Ridge Gaseous Diffusion Plant (ORGDP), and the Oak Ridge Y-12 Plant. Information about the exact dates during which material was stored in this area and the amounts of material contributed by the respective plants is limited. The material consisted largely of contaminated steel tanks, trucks, earth-moving equipment, and large pieces of steel, stainless steel, and aluminum, as well as reactor vessels used in Building 3019 of ORNL.

Efforts were made from 1966 to 1971 to remove the contaminated material and clean up the site. These efforts included the survey of material to identify the amount of contamination present in order to dispose of the material properly. Approximately $6000 \mathrm{yd}^{3}$ of contaminated soil that gave radiation readings ranging from 1 to $50 \mathrm{mR} / \mathrm{hr}$ was removed during cleanup operations from an area south of the access road.

A radiological survey conducted on June 5, 1971, led to the conclusion that the entire area of White Wing Scrap Yard (WAG 11) was still extensively contaminated and that there was a problem with subsurface conditions. Eleven groundwater quality monitoring wells were installed along the perimeter of WAG 11 (Fig. 1, map pocket). 


\section{INSTALLATION METHODS}

Four basic types of well construction were used during the GQM installation program at ORNL. Schematic diagrams of these four well types are shown on Fig. 2. Three of the four types (A, B, and C) were used at WAG 11. These types are described in Sects. 2.1 through 2.3. The specific details of each well installation are included in the monitoring well narratives (Appendix A). The specifications for drilling and well installation were provided in Construction Specifications for Monitoring Wells Installation Construction Project, K-4491G-G1. ${ }^{1}$ The proposed well design criteria for the WAG 11 wells can be found in the report Preliminary Geohydrologic Site Characterization and Proposed Water Quality Well Locations for WAG 11, ORNL/RAP/Sub/87-SB189/1. ${ }^{2}$ Actual completion data for WAG 11 are listed in Table 1.

\subsection{TYPE A WELL}

The type A well boring is drilled to total depth with solid-stem augers. On completion, the boring is bailed with a steel bailer to remove drill cuttings. The well is completed with 2in.-diam stainless steel screen, casing, and a silt trap. Stainless steel centralizers are positioned at the top of the screen and every $20 \mathrm{ft}$ along the casing. A sandpack is poured into the annular space from total depth to $1 \mathrm{ft}$ above the screen. Pelleted bentonite is poured into the annular space to create a 2 -ft seal above the sandpack. The top of the bentonite seal is measured with a stainless steel weighted tape. The annular space above the bentonite seal is then grouted to the surface through a tremie pipe.

\subsection{TYPE B WELL}

The first step in drilling the type B well is to auger a boring from the surface to a depth of $4 \mathrm{ft}$. A steel diverter casing is installed, and the annulus is grouted to the surface. The boring is then deepened with a tricone air rotary bit to a minimum depth of $10 \mathrm{ft}$ total and $2 \mathrm{ft}$ into bedrock. Next, a steel surface casing is installed and grouted into place. The air rotary method is used to drill the boring to the required depth. The well is completed with 4-in.-diam stainless steel screen and casing. A sandpack, a bentonite seal, and grout are installed in the annular space by the same procedures as used for the type A well.

\subsection{TYPE D WELL}

A type $D$ well is a type $A$ well with a diverter casing. If the auger encounters refusal before reaching total depth on a type $A$ well, the boring is reamed with a larger auger to refusal, and a steel diverter casing is installed. The annulus is grouted up to surface level. The boring is deepened with a tricone air rotary bit to total depth, and the well is completed with 2-in.-diam stainless steel screen and casing. A sandpack, a bentonite seal, and grout are installed in the annular space by the same procedures as those used for the type A well. 


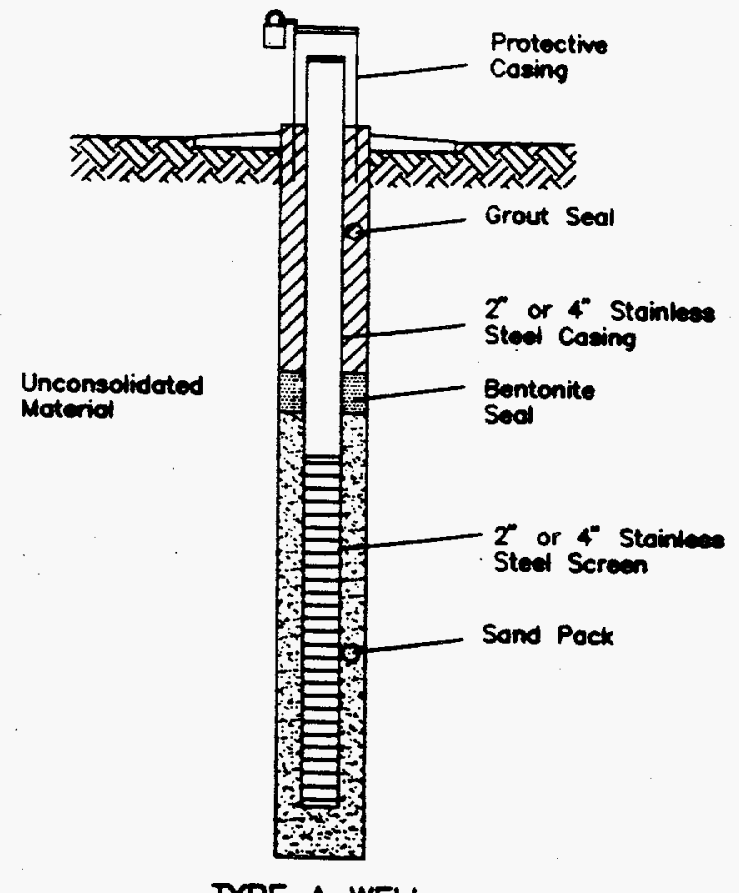

TYPE A WELL

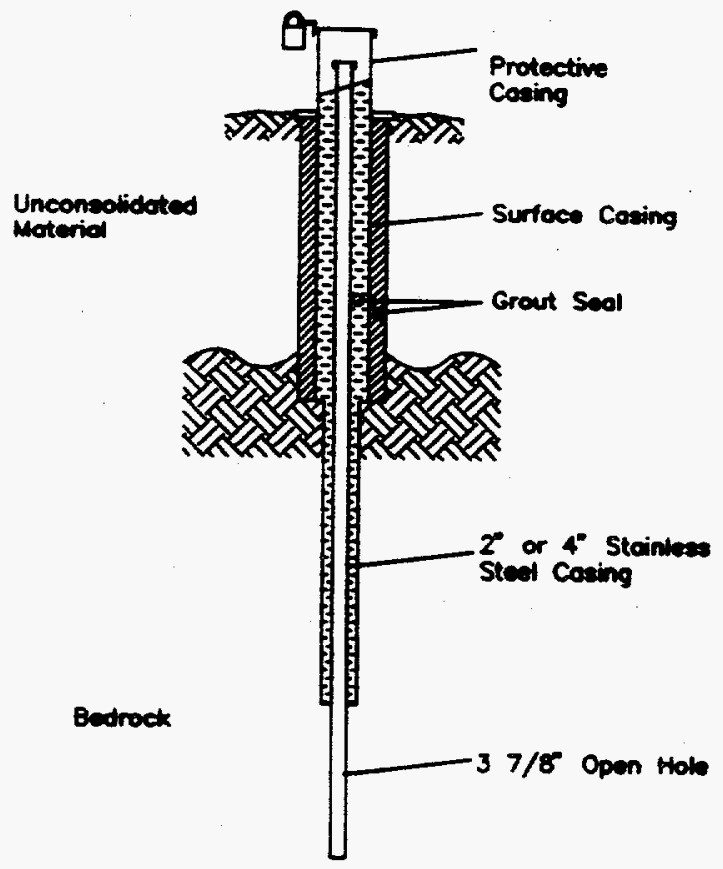

TYPE C WELL

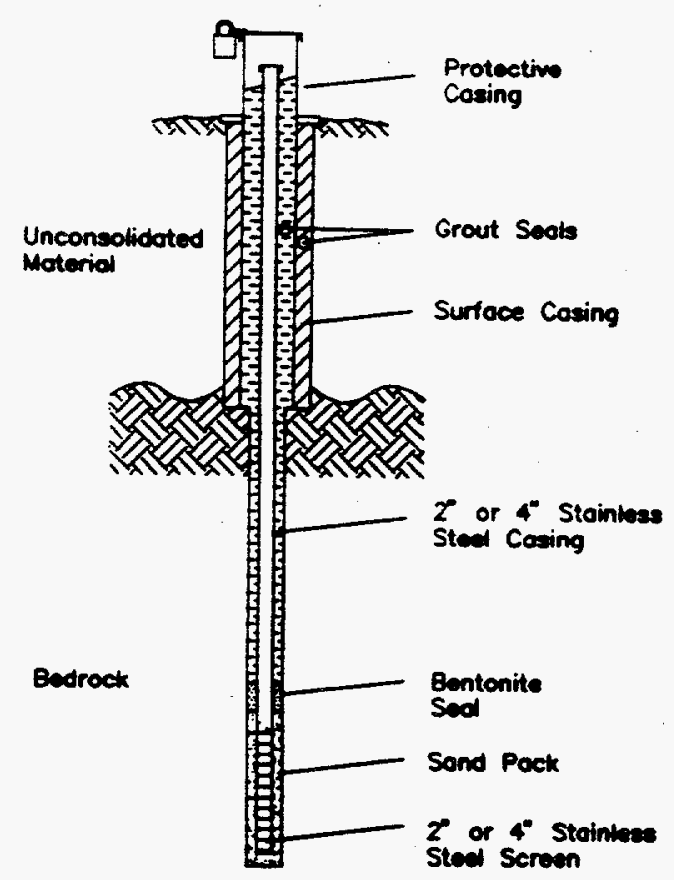

TYPE B WELL

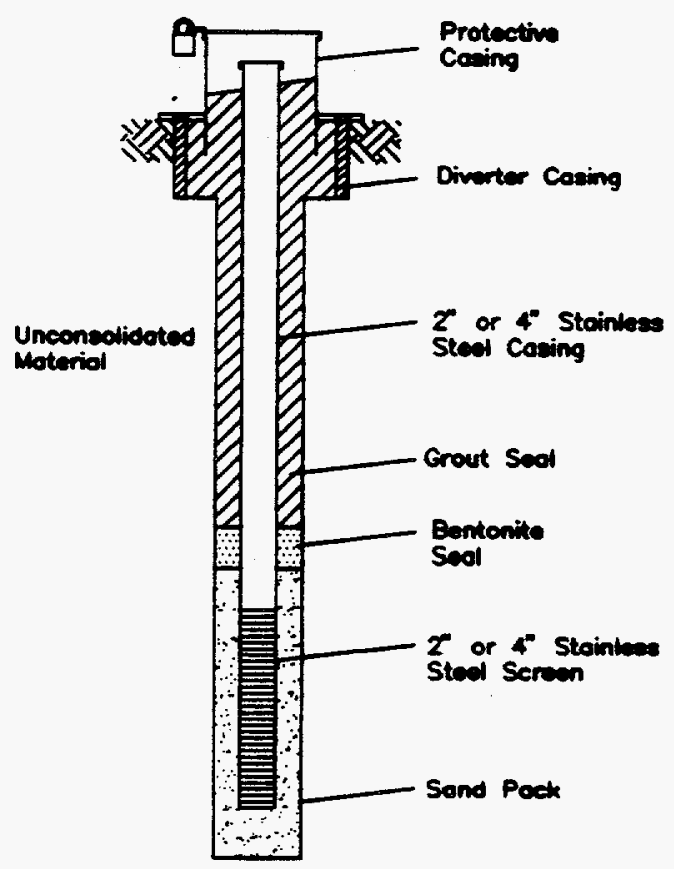

TYPE D WELL

Fig. 2. The four types of well construction used during the Groundwater Quality Monitoring Well Installation Program at Oak Ridge National Laboratory. 
Table 1. Actual completion data for WAG 11

\begin{tabular}{cccccc}
\hline Well & $\begin{array}{c}\text { Depth } \\
\text { clean to } \\
(\mathrm{ft})^{a}\end{array}$ & $\begin{array}{c}\text { SST casing } \\
\text { diam(in.) }\end{array}$ & $\begin{array}{c}\text { Well } \\
\text { type }\end{array}$ & $\begin{array}{c}\text { Screened } \\
\text { interval (ft) }\end{array}$ & $\begin{array}{c}\text { Water } \\
\text { level } \\
(\mathrm{ft})^{b}\end{array}$ \\
\hline 1139 & 33.0 & 2 & A & $7.8-32.8$ & -5.1 \\
1140 & 62.5 & 2 & D & $32.2-62.3$ & -51.1 \\
1141 & 97.4 & 4 & B & $82.2-97.2$ & -58.3 \\
1143 & 52.5 & 4 & B & $37.5-52.2$ & -24.8 \\
1144 & 122.3 & 4 & B & $102.1-122.1$ & -21.1 \\
1145 & 59.1 & 2 & A & $38.0-58.9$ & -52.3 \\
1146 & 117.3 & 4 & B & $107.1-117.1$ & -79.4 \\
1147 & 97.9 & 4 & B & $77.7-97.7$ & -82.1 \\
1148 & 67.5 & 4 & B & $52.2-67.2$ & -9.5 \\
1149 & 32.8 & 4 & B & $17.5-32.5$ & -10.2 \\
1246 & 86.63 & 4 & B & $56.4-71.4$ & -31.5 \\
\hline
\end{tabular}

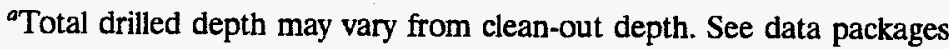
(Appendix A).

${ }^{b}$ Predevelopment water level; depth measured from ground surface. (Negative is below surface; positive, above surface.) 


\section{ENVIRONMENTAL, HEALTH, AND SAFETY REQUIREMENTS}

All well drilling at WAG 11 was conducted in accordance with procedures outlined in Health, Safety, and Environmental Protection Procedures for Excavating Operations, ORNL/M-116/R1 ${ }^{3}$. Among the procedures set forth by this document is a system for rating proposed well locations according to the degree of probability that contamination will be encountered. Ratings obtained by this system were used to determine the level of personnel training required and health and safety coverage to be used during drilling.

The Superfund Amendment Reauthorization Act required still more stringent health and safety measures for personnel working in waste areas. These workers were required to have $40 \mathrm{~h}$ of training for hazardous duty through an ORNL-approved course, $8 \mathrm{~h}$ of refresher training each year, $8 \mathrm{~h}$ of supervisor's training for field supervisors, a whole-body count, baseline urinalysis, respirator testing and fitting, and medical monitoring. Personnel were also required to take a construction-worker training course covering the fundamentals of radioactivity and other types of contamination as well as the other hazards that could be encountered at ORNL. The workers were taught the proper procedures to follow in the event of an on-site emergency.

Special procedures were used during drilling. The ground surface at all drill sites was covered with polyethylene sheeting to prevent contact between the tools and the ground. The sheeting would also have protected the environment in the event of a hydraulic fluid release. Containment was required for all drill cuttings produced. During augering, a metal pan was used to hold cuttings until a health physicist (HP) could determine their proper disposition. During air rotary drilling, cuttings were diverted from the borehole to a special containment box designed by Martin Marietta Energy Systems, Inc. (Energy Systems). The box is a 500-gal, trailer-mounted tank with demister elements and high-efficiency particulate air filters at the air exhaust. In order that appropriate methods of disposal could be determined, the tank contents were checked by the HP for radioactive contamination and by the site hydrogeologist for volatile organics. The operating instructions that were followed for determining disposition of the cuttings and water produced during drilling and development are included in Appendix B. 


\section{FIELD SUPPORT}

The construction contractor Geotek Engineering Company, whose contract began in May 1989, installed the GQM wells in WAG 11. ORNL Engineering administered the drilling contract through Energy Systems Procurement. The management organization chart for the project is in the Task Management Plan for Groundwater Quality Monitoring Well Installation, ORNL/RAP/LTR-88/29.4

The hydrogeologic support and installation record keeping were supplied through a contract with ERC Environmental and Energy Services Company (ERCE), formerly EDGe/MCI. An ERCE representative was present during all activities that affected the quality of the wells and advised Energy Systems on well construction. ORNL personnel or their subcontractors provided HP and industrial hygiene support .

Construction engineering support was supplied by Energy Systems personnel. Drawings, excavation permits, well placement in the field, and as-built surveying and calculations were done by the Energy Systems Civil and Architectural Department or by their subcontractor, Adams Craft Herz Walker Engineering Company. The as-built survey coordinates and elevations are on the well installation/completion form for each well (Appendix A). The as-built coordinates are also summarized in a table on the well location map (Fig. 1). 


\section{DRILLING RECORDS}

A complete data package has been compiled for each of the $11 \mathrm{GQM}$ wells drilled in WAG 11. These data packages are presented in numerical order in Appendix A. All original records are retained in the Environmental Restoration (ER) Division Records Control Data Base. The forms included in each well data package are listed here in the order in which they appear in the package:

1. monitor well narrative,

2. predrilling checklist for monitoring wells,

3. decontamination checklist for drilling equipment,

4. well log,

5. well installation/completion form,

6. monitoring well materials certification,

7. post-well completion checklist,

8. monitoring well development form,

9. monitoring well development progress,

10. hydraulic conductivity calculation,

11. nonconformance report (if necessary), and

12. chain of custody forms.

Three additional forms used in the field by the site hydrogeologist but not included in the published data packages are the monitoring well progress form, the hydraulic conductivity test field sheet, and the containment box checklist. These forms are also kept in the ER Division Records Control Data Base. 


\section{WELL DEVELOPMENT}

Wells were developed by pumping. Wells with high initial turbidities were surged beforehand with a workover rig and a stainless steel surge block to facilitate removal of the sediment from the wells. The contents of the wells were then pumped out using Geoguard airlift pumps and oilless air compressors. Development of a well was considered complete when at least three well volumes had been removed and the turbidity was measured at 5 NTUs or less. Several wells had turbidity ratings higher than 5 NTUs even after extensive pumping, but, in order to prevent the pulling in of groundwater from too far away, a maximum limit of 30 to 35 well volumes was determined by Energy Systems hydrogeologists to be the upper limit that should be removed. The contents of the wells were pumped out using Geoguard development pumps. The two-stage Geoguard pumps were converted to dedicated bladder pumps for sampling after development was complete. All development water was contained and disposed of according to the operating instructions in Appendix B.

Of the 11 wells in WAG 11,9 had turbidities less than or equal to 5 NTUs. The number of well volumes removed ranged from 4.0 to 34.2 , with an average of 15.6 well volumes. The procedure for measuring turbidity described in ORNL/RAP/LTR-88/28 ${ }^{4}$ was replaced with a more accurate method. While the previously used method depended on a visual comparison of the sample with prepared standards, the new method employs the Cole-Parmer turbidimeter, which measures NTUs by passing a lens-focused light beam through a test tube filled with a water sample. A photosensor detects the intensity of the exiting light beam, and an analog scale on the instrument displays the turbidity of the sample. 


\section{SAMPLING DURING INSTALLATION}

The ERCE hydrogeologist took samples of soil, rock, and drilling water during well installation and submitted them to the ORNL Analytical Chemistry Division for chemical analyses. Soil and rock samples were taken from the unsaturated and saturated zones. Samples of drilling water were collected from the water pump discharge on the drill rig during air rotary drilling. All samples were transferred using chain-of-custody forms, which are included in the data packages. The sampling procedures are explained in ORNL/RAP/LTR-88/28. ${ }^{4}$ Soil samples were collected from each single well and from one well of each well pair. A drilling-water sample was collected from each air-rotary-drilled boring.

Analyses for 31 chemical elements, gross alpha, gross beta, and ${ }^{40} \mathrm{~K}$ were routinely performed on the soil and water samples. The results from these analyses are contained in the ER Division Records Control Data Base. 


\section{SPECIAL NOTES ON INSTALLATION AND DEVELOPMENT}

The following special events took place during the drilling of the GQM wells in WAG 11.

\subsection{CONTAMINATION DETECTED}

The ERCE hydrogeologist detected an unusual reddish color in the drill water generated in well 1149

\subsection{DEVIATIONS FROM THE SPECIFICATIONS}

- An obstruction was encountered in well 1146 at a depth of $118 \mathrm{ft}$. Well casing was set above it. Filling the annulus required an excessive amount of grout. During the grouting process, a $30-\mathrm{ft}$ section of tremie pipe was dropped into the annulus and was encapsulated in grout.

- A stainless steel weighted tape was dropped into the well annulus of well 1148 and was encapsulated in bentonite and grout.

\subsection{HYDRAULIC FLUID SPILIS}

A hydraulic hose broke during drilling of well 1140 , but the boring was not contaminated. 


\section{REFERENCES}

1. Engineering Division, Construction Specifications for Monitoring Wells Installation Construction Project, K-4491G-G1 (Rev. 2), Martin Marietta Energy Systems, Inc., Oak Ridge National Laboratory, Oak Ridge, Tenn. August 1988.

2. Engineering, Design and Geosciences Group, Inc., Preliminary Geohydrologic/Site Characterization and Proposed Water Quality Well Locations for WAG 11 AND Upper WAG 2, ORNL/RAP/Sub-87/SB189/1, Martin Marietta Energy Systems, Inc., Oak Ridge National Laboratory, Oak Ridge, Tenn., September 1987.

3. Environmental Compliance and Health Protection Division, Health, Safety, and Environmental Protection Procedures for Excavating Operations, ORNL/M-116/R1, Martin Marietta Energy Systems, Inc., Oak Ridge National Laboratory, Oak Ridge, Tenn., March 3, 1988.

4. J. A. Mortimore, Task Management Plan for Groundwater Quality Monitoring Well Installation, ORNL/RAP/LTR-88/28, Martin Marietta Energy Systems, Inc., Oak Ridge National Laboratory, Oak Ridge, Tenn., February 1988. 
Appendix A

Data Packages 
ERC / EDGE

Environmental

and Energy

Services Co.
MONTTORING WEZL PROGRAN

WEZL DATA NARRA TVE WELL NO. 1139

\subsection{General Information}

\subsection{Nell Location}

Monitoring well number 1139 is located in WAG 11. It is located in the southern boundary of White wing scrap Yard. The location is shown on ORNL drawing number C3E20004A075. Survey coordinates for this well are $N$ $34,507.9669$, E $28,700.6980(\mathrm{Y}-12 \mathrm{grid})$ or latitude $35^{\circ}-$ $57^{\prime}-05.50^{\prime \prime}$ and longitude $84^{\circ}-20^{\prime}-48.93^{\prime \prime}$. Coordinate data were provided by Martin Marietta Energy systems. The method used for conversion from $\mathrm{Y}-12$ grid to TennesseeLambert state Plane coordinates came from the publication "Tennessee Valley Authority Data Services Branch and Mapping Services Branch, Oak Ridge, Tennessee, DOE Plant Control, November 6, 1985, Field Book: Ess-3115, pp. 120." The latitude and longitude were calculated by Adams Craft Herz Walker Engineering, Inc., using methods from the U.S. Coast and Geodetic Survey Publication 62-4, "State Plane Coordinates by Automatic Data Processing."

\subsection{Driliing Information}

Well number 1139 was drilled by Geotek Engineering Company. An Ingersoll Rand T-4 rig was used to drill this boring for monitor well installation under operation of Larry Ledbetter with the assistance of Fred Dixon. Drilling commenced on 1-19-90 and was finished on 1-22-90. Paragraph 2.4.1 includes a detailed discussion of the well installation and a well schematic is included 
on the well installation/ completion form. A synopsis of the drilling activity follows. This information was typed directly from field notes and was edited only when necessary for clarification.

1-19-90 The rig was mobilized to the staked location and set up on plastic sheeting. Split spoon samples were taken from surface to refusal at 7.5 feet. The boring was deepened with a 6-inch auger to 22.5 feet.

1-22-90 The boring was deepened from 22.5 feet to auger refusal at 33.5 feet with a 6 -inch auger. Two inch stainless steel screen and casing was then set with sand pack and bentonite pellet seal. 1-23-90 The annulus was grouted to surface with 1 sack cement.

This well was logged by ERC Environmental and Energy Services Co., Inc., hydrogeologist Timothy A. Lee. All well construction materials and supplies were from Martin Marietta Energy Systems approved batches. The batch origin of individual items is shown on the included Monitoring Well Materials Certification form.

\subsection{Technical Information}

\subsection{Decontamination Procedures}

The drilling rig, down hole tools, surface casing, stainless steel screen, stainless steel casing, centralizers, and stainless steel silt trap underwent the cleaning decontamination procedures outlined in the drilling specifications (Release Specific Technical Directions for Regulatory Compliance Monitoring Wells 
Phase 1, Oak Ridge National Laboratory, Oak Ridge, w.0., K-4147, April 1987, pgs, 2-4). A checklist of the cleaned materials is included with this data package.

\subsection{Geology}

The northeastern half of WAG 11 is underlain by Chickamauga Limestone. The Rome Formation underlies the southwestern half of WAG 11. The Chickamauga Limestone is brought into contact with the Rome Formation by the White Oak Mountain thrust fault, the trace of which bisects WAG 11 from northwest to southeast. The lowermost beds of the Chickamauga are composed of thin bentonitic beds, gray clay shale, and maroon to gray calcareous siltstone. The majority of the chickamauga, approximately 1,500 feet thick, is a dominantly gray, dense, finely crystalline, thin bedded limestone with varying amounts of chert. The uppermost beds consist of yellow and maroon calcareous siltstone and blue-gray limestone. The Rome Formation is composed of interbedded sandstone, siltstone, shale, and, locally, dolomite.

\section{3 sample collection}

One soil sample was collected during drilling, placed in an I-CHEM specialty cleaned glass container, sealed and submitted to Sample Receiving, Analytical Chemistry Division, Bldg. 4500S, ORNL. A chain of custody form for this sample is included with this data package. Soil sample 1139501 was collected in the split spoon interval from 6.2 to 6.5 feet on 1-19-90. 
A bulk density soil sample was collected from the split spoon sample interval from 1.0 to 1.3 feet. The sample was measured and weighed, and a bulk density of 2.22 grams $/ \mathrm{cm}^{3}$ was calculated.

\subsection{Installation and Development}

\subsubsection{Installation}

This was a Type A well. A 6-inch diameter boring was split spooned and augered from ground surface to a total depth of 33.5 feet. A 2-inch diameter stainless steel screen with threaded bottom cap was installed from 7.8 feet to 33.0 feet. A 2-inch diameter stainless steel casing was installed above the screen from 7.8 feet to 2.2 feet above ground surface. A sandpack was then tremied into the annular space from 4.4 to 33.9 feet, with a 1.6 foot bentonite pellet seal poured into the annular space above the sandpack from 2.8 to 4.4 feet. The annular space from the top of the bentonite seal to the surface was tremie grouted with a cement/bentonite slurry. A detailed schematic of the well is included on the well installation/completion form.

\subsubsection{Well Dovelopment}

Well number 1139 was developed to remove drill cuttings, silt, and other fines. The monitoring well was developed using a Geoguard pump with an air compressor. All pumps were cleaned prior to use according to specified cleaning procedures (see Paragraph 2.1). The well was developed until a measured total of 565 gallons of water had been evacuated and the clarity of the discharge water was 
ERC / EDGE

Environmental

and Energy

Services Co.
MONITORING WEZL PROORAM

WEL DATA NARRA TVE

WELL NO. 1139

approved by the company representative. The final

turbidity value measured at completion was $>100$ NTU's. A

development form showing the exact method of development

and other pertinent data is appended.

2.4.3 Installation of Dedicated Monitoring Nell Pump

After the well was developed, a Geoguard Model No. 5614 dedicated monitoring well pump was installed on 7/31/90 at a depth of 29.8 feet below ground surface. These pumps are decontaminated at American sigma and are sent prepackaged. A copy of the pump certification is kept on file at ORNL.

\subsection{Hydraulic conductivity resting}

Well number 1139 was tested for the determination of hydraulic conductivity of the aquifer in the vicinity of the well screen. This was accomplished by instantaneously adding a known quantity of water to the monitoring well and measuring the recovery of the water level over time. The changing water levels were measured using a Druck 15 psi pressure transducer and an Omnidata Datapod II data recorder. The hydraulic conductivity value of $2.71 \times 10^{-3} \mathrm{~cm} /$ second (shown as permeability on the hydraulic conductivity calculations printout attached) was calculated using the Bouwer and Rice method. A computer printout of the hydraulic conductivity calculations is included in this data package. 


\subsection{Well Location}

Monitoring we11 number 1140 is located in WAG 11 . It is located in the southern boundary of white wing scrap Yard. The location is shown on ORNL drawing number C3E20004A075. Survey coordinates for this well are N 34,497.9754, E 28,111.2064 (Y-12 grid) or latitude $35^{\circ}-57^{\prime}-02.17^{\prime \prime}$ and longitude $84^{\circ}-20^{\prime}-54.82^{\prime \prime}$. Coordinate data were provided by Martin Marietta Energy Systems. The method used for conversion from Y-12 grid to Tennessee-Lambert state Plane Coordinates came from the publication "Tennessee Valley Authority Data Services Branch and Mapping Services Branch, Oak Ridge, Tennessee, DOE Plant Control, November 6, 1985, Field Book: Ess-3115, pp. 1-20." The latitude and longitude were calculated by Adams Craft Herz Walker Engineering, Inc., using methods from the U.S. Coast and Geodetic Survey Publication 62-4, "state Plane coordinates by Automatic Data Processing."

\subsection{Drilling Information}

Well number 1140 was drilled by Geotek Engineering Company. An Ingersoll Rand T-4 rig was used to drill this boring for monitor well installation under operation of Larry Ledbetter with the assistance of Fred Dixon. Drilling commenced on 1-31-90 and was finished on 3-5-90. Paragraph 2.4.1 includes a detailed discussion of the well installation and a well schematic is included on the 
ERC / EDGE

Environmental

and Energy

Services Co.
MONITORING WELL PROCRAM

WEZL DATA NARRATVE WELL NO. 1140

well installation/completion form. A synopsis of the drilling activity follows. This information was typed directly from field notes and was edited only when necessary for clarification.

1-19-90 The rig was mobilized to the staked location and set up on plastic sheeting. The boring was augered to 6.0 feet with a 14 -inch auger. Set 6.0 feet of $103 / 4-$ inch decontaminated steel diverter casing and grouted it into place. Moved rig from location.

3-2-90 The rig was moved to location. Drilled to 62.5 feet using an 8.0-inch air rotary tricone bit.

3-5-90 Set 2-inch stainless steel screen and casing with sandpack and bentonite pellet seal. Move rig from location.

3-6-90 Grouted annulus with 7.0 sacks cement.

This well was logged by ERC Environmental and Energy Services Co., Inc., hydrogeologist Timothy A. Lee. All well construction materials and supplies were from Martin Marietta Energy Systems approved batches. The batch origin of individual items is shown on the included Monitoring Well Materials Certification form.

\subsection{Technical Information}

\subsection{Decontamination Procedures}

The drilling rig, down hole tools, surface casing, stainless steel screen, stainless steel casing, 
centralizers, and stainless steel silt trap underwent the cleaning decontamination procedures outlined in the drilling specifications (Release Specific Technical Directions for Regulatory Compliance Monitoring Wells Phase 1, Oak Ridge National Laboratory, Oak Ridge, w.0. K-4147, April 1987, pgs. 2-4). A checklist of the cleaned materials is included with this data package.

\subsection{Geology}

The northeastern half of WAG 11 is underlain by Chickamauga Limestone. The Rome Formation underlies the southwestern half of WAG 11 . The Chickamauga Limestone is brought into contact with the Rome Formation by the White Oak Mountain thrust fault, the trace of which bisects WAG 11 from northwest to southeast. The lowermost beds of the chickamauga are composed of thin bentonitic beds, gray clay shale, and maroon to gray calcareous siltstone. The majority of the chickamauga, approximately 1,500 ' thick, is a dominantly gray, dense, finely crystalline, thin bedded limestone with varying amounts of chert. The uppermost beds consist of yellow and maroon calcareous siltstone and blue-gray limestone. The Rome Formation is composed of interbedded sandstone, siltstone, shale, and, locally, dolomite.

\section{3 sample collection}

A bulk density soil sample was collected from the split spoon sample interval from 3.5 to 3.8 feet. The sample was measured and weighed, and a bulk density of 2.22 grams $/ \mathrm{cm}^{3}$ was calculated. No samples were collected during drilling for chemical analysis. 
ERC / EDGE

Environmental

and Enerey

Services Co.
MONITORING WEU PROGRAM

WEIL OATA NARRATVE

neZL No. 1140

The Ingersoll Rand T-4 compressed air was sampled with a cloth filter inserted between drill rods on $3 / 2 / 90$. The sample was examined with an ultraviolet light for the presence of hydrocarbons. The filter showed no detectable signs of hydrocarbons.

\subsection{Installation and Development}

\subsubsection{Installation}

This was a Type D well. A 14.0-inch diameter boring was augered from ground surface to 6.0 feet and a $103 / 4-$ inch diverter casing was installed and grouted. An 8-inch diameter boring was then drilled with an air rotary tricone roller bit from 6.0 to 62.5 feet. A 2-inch diameter stainless steel screen with threaded bottom cap was installed from 32.3 to 62.5 feet. A 2-inch diameter stainless steel casing was installed above the screen at 32.3 feet and extended 2.8 feet above ground surface. A sandpack was then tremied into the annular space from 30.5 to 62.5 feet, with a 1.5 foot bentonite pellet seal poured into the annular space above the sandpack from 29.0 to 30.5 feet. The annular space from the top of the bentonite seal to the surface was tremie-grouted with a cement/bentonite slurry. A detail of the well is included on the well installation/completion form.

\subsubsection{We11 Development}

Well number 1140 was developed to remove drill cuttings, silt, and other fines. The monitoring well was developed using a Geoguard pump with an air compressor. All pumps were cleaned prior to use according to specified cleaning procedures (see Paragraph 2.1). The well was developed 
until a measured total of 120 gallons of water had been evacuated and the clarity of the discharge water was approved by the company representative. The final turbidity value measured at completion was 4.0 NTU's. A development form showing the exact method of development and other pertinent data is appended.

\subsubsection{Installation of Dedicated Monitoring we11 Pump}

After the well was developed, a Geoguard Model No. 5614 dedicated monitoring well pump was installed on $8 / 16 / 90$ at a depth of 61.6 feet below ground surface. These pumps are decontaminated at American sigma and are sent prepackaged. A copy of the pump certification is kept on file at ORNL.

\subsection{Hydraulic Conductivity Teating}

Well number 1140 was tested for the determination of hydraulic conductivity of the aquifer in the vicinity of the well screen. This was accomplished by instantaneously adding a known quantity of water to the monitoring well and measuring the recovery of the water level over time. The changing water levels were measured using a Druck 15 psi pressure transducer and an Omnidata Datapod II data recorder. The hydraulic conductivity value of $1.17 \times 10^{-4} \mathrm{~cm} /$ second (shown as permeability on the hydraulic conductivity calculations printout attached) was calculated using the Bouwer and Rice method. A computer printout of the hydraulic conductivity calculations is included in this data package. 
ERC / EDGE

Environmental

and Energy

Services Co.

General Information

\subsection{Nell Location}

Monitoring well number 1141 is located in WAG 11. It is located in the southern boundary of white wing scrap Yard. The location is shown on ORNL drawing number C3E20004A075. Survey coordinates for this well are $N$ $34,488.6430$, E 28,148.8969 (Y-12 grid) or latitude $35^{\circ}-$ 57'-02.30" and longitude 84 ${ }^{\circ}-20^{\prime}-54.38^{\prime \prime}$. Coordinate data were provided by Martin Marietta Energy Systems. The method used for conversion from $\mathrm{Y}-12$ grid to TennesseeLambert State Plane Coordinates came from the publication "Tennessee Valley Authority Data Services Branch and Mapping Services Branch, Oak Ridge, Tennessee, DOE Plant Control, November 6, 1985, Field Book: ESS-3115, pp. 120." The latitude and longitude were calculated by Adams Craft Herz Walker Engineering, Inc., using methods from the U.S. Coast and Geodetic Survey Publication 62-4, "State Plane Coordinates by Automatic Data Processing."

\subsection{Drilling Information}

Well number 1141 was drilled by Geotek Engineering Company. An Ingersoll Rand T-4 rig was used to drill this boring for monitor well installation under operation of Larry Ledbetter with the assistance of Fred Dixon. Drilling commenced on 1-30-90 and was finished on 2-14-90. Paragraph 2.4.1 includes a detailed discussion of the well installation and a well schematic is included on the well installation/completion form. A synopsis of the drilling activity follows. This information was typed directly from field notes and was edited only when necessary for clarification. 
ERC / EDGE

Environmental

and Energy

Services Co.

MONITORING WEZL PROSRAM

WEIL OATA NARRA IVE

MELL NO. 1141

1-30-90 The rig was mobilized to location and set up on plastic sheeting. Split spoon samples were taken from surface to first refusal at 5.6 feet. The boring was deepened with a 6-inch auger to 29.0 feet. Split spoons were taken from 29.0 feet to refusal at 34.7 feet. The boring was deepened from 34.7 feet to refusal at 58.0 feet using a 6-inch auger. Six feet of 15 1/4-inch decontaminated diverter casing was set and grouted. The rig was moved from location.

2-8-90 The rig was moved to location. Drill from 6.0 feet to 60.5 feet using a 14 1/2-inch air rotary tricone bit. Set 60.5 feet of $103 / 4-$ inch decontaminated steel surface casing and grouted it to surface. The rig was moved from location.

2-14-90 Move rig to location. Drill from 60.5 feet to 97.5 feet using an 8-inch air rotary tricone bit. Set 97.4 feet of 4-inch stainless steel screen and casing with sandpack and bentonite seal.

2-15-90 Grouted stainless steel casing annulus with 17 sacks cement.

This well was logged by ERC Environmental and Energy Services Co., Inc., hydrogeologist Timothy A. Lee. AlI well construction materials and supplies were from Martin Marietta Energy Systems approved batches. The batch origin of individual items is shown on the included Monitoring Well Materials Certification form. 
ERC / EDGE

Environmental

and Energy

Services Co.

2.0 Technical Information

\subsection{Decontamination Procedures}

The drilling rig, down hole tools, surface casing, stainless steel screen, stainless steel casing, centralizers, and stainless steel silt trap underwent the cleaning decontamination procedures outlined in the drilling specifications (Release Specific Technical Directions for Regulatory Compliance Monitoring Wells Phase 1, Oak Ridge National Laboratory, Oak Ridge, W.0. K-4147, April 1987, pgs. 2-4). A checklist of the cleaned materials is included with this data package.

\subsection{Geology}

The northeastern half of WAG 11 is underlain by Chickamauga Limestone. The Rome Formation underlies the southwestern half of WAG 11. The Chickamauga Limestone is brought into contact with the Rome Formation by the White Oak Mountain thrust fault, the trace of which bisects WAG 11 from northwest to southeast. The lowermost beds of the Chickamauga are composed of thin bentonitic beds, gray clay shale, and maroon to gray calcareous siltstone. The majority of the Chickamauga, approximately 1,500 feet thick, is a dominantly gray, dense, finely crystalline, thin bedded limestone with varying amounts of chert. The uppermost beds consist of yellow and maroon calcareous siltstone and blue-gray limestone. The Rome Formation is composed of interbedded sandstone, siltstone, shale, and, locally, dolomite. 


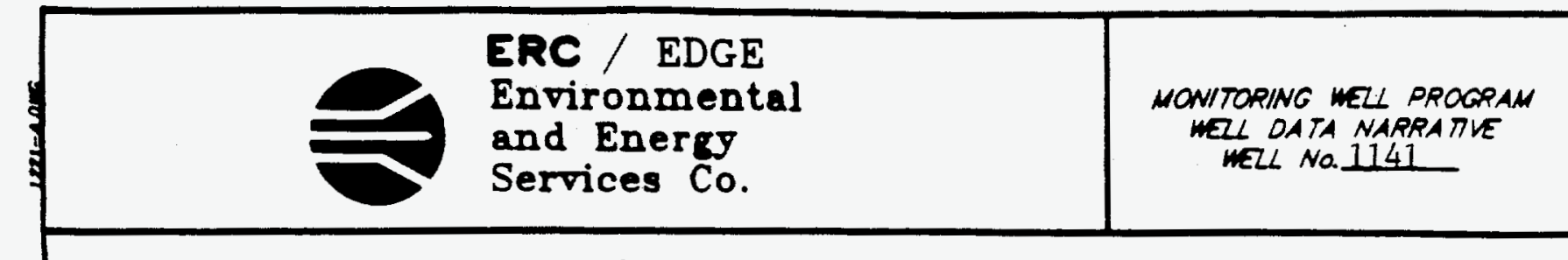

\section{3 sample collection}

One soil sample was collected during drilling, placed in an I-CHEM specialty cleaned glass container, sealed and submitted to Sample Receiving, Analytical Chemistry Division, Bldg. 4500S, ORNL. A chain of custody form for this sample is included with this data package. Soil sample 1141501 was collected in the split spoon interval from 4.0 to 4.3 feet on 1-30-90.

A bulk density soil sample was collected from the split spoon sample interval from 3.5 to 3.8 feet. The sample was measured and weighed, and a buik density of 2.11 grams $/ \mathrm{cm}^{3}$ was calculated.

The Ingersoll Rand $\mathrm{T}-4$ compressed air was sampled with a cloth filter inserted between drill rods on 2-14-90. The sample was examined with an ultraviolet light for the presence of hydrocarbons. The filter showed no detectable signs of hydrocarbons.

\subsection{Installation and Derelopment}

\subsubsection{Installation}

This was a Type B well. A 22.0-inch diameter boring was augered from ground surface to 6.0 feet. A $151 / 4$-inch diverter casing was installed from surface to 6.0 feet below ground surface and grouted in place. The boring was then extended past the refusal depth with a 14.5-inch air rotary tricone roller bit from 6.0 feet to 60.5 feet. A 10 3/4-inch diameter string of decontaminated steel surface casing was installed from 0.0 feet to 60.5 feet, sealed with a 1.5 foot bentonite pellet layer from 59.0 
ERC / EDGE

Environmental

and Energy

Services Co.
NONITORING WELL PROGRAM

WEL DATA NARRATVE

NELL NO. 1141

feet to 60.5 feet, and tremie grouted in place. The surface casing minimizes potential cross contamination between the regolith and bedrock water bearing zones. After the surface casing was installed, the air rotary method was used to drill an 8-inch diameter boring to a total depth of 97.5 feet. A 4-inch diameter stainless steel screen with threaded bottom cap was installed from 82.2 feet to 97.4 feet. A 4-inch diameter stainless steel casing was installed from the top of the screen at 82.2 feet and extended 2.8 feet above ground surface. A sandpack was then tremied into the annular space from 77.9 to 97.4 feet, with a 1.8 foot bentonite pellet seal poured into the annular space above the sandpack from 76.1 to 77.9 feet. The annular space from the top of the bentonite seal to the surface was tremie grouted with a cement/bentonite slurry. A detailed schematic of the well is included on the well installation/completion form.

\subsubsection{We11 Development}

Well number 1141 was developed to remove drill cuttings, silt, and other fines. The monitoring well was developed using a Geoguard pump with an air compressor. All pumps were cleaned prior to use according to specified cleaning procedures (see Paragraph 2.1). The well was developed until a measured total of 160 gallons of water had been evacuated and the clarity of the discharge water was approved by the company representative. The final turbidity value measured at completion was $4.0 \mathrm{NTU} / \mathrm{s}$. A development form showing the exact method of development and other pertinent data is appended. 


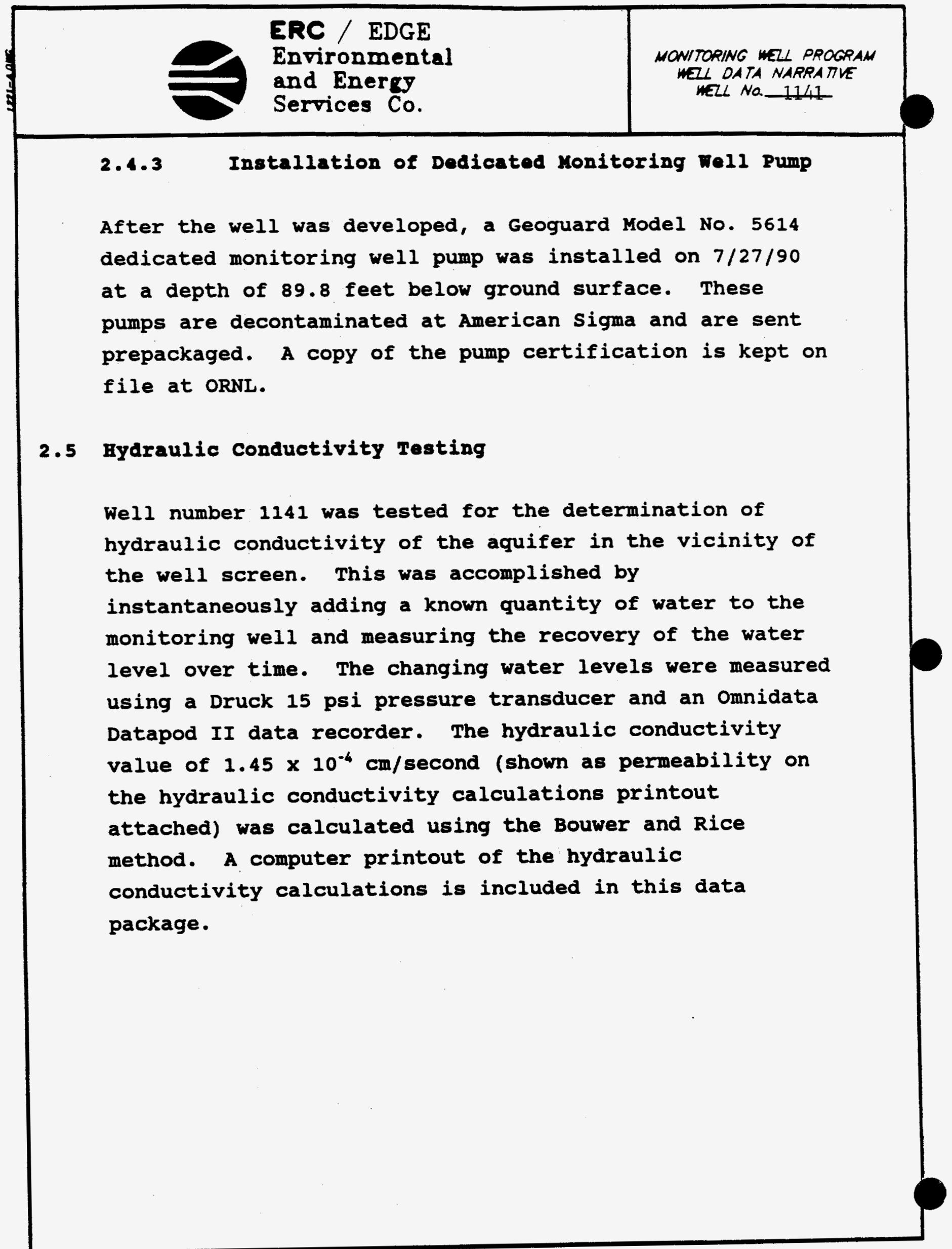

PACE 6 of 22 


\subsection{Well Location}

Monitoring well number 1143 is located in WAG 11. It is located in the southern boundary of White wing scrap Yard. The location is shown on ORNL drawing number C3E20004A075. Survey coordinates for this well are $N$ $35,068.4127, E 27,569.5606$ (Y-12 grid) or latitude $35^{\circ}$ $57^{\prime}-03.88^{\prime \prime}$ and longitude $84^{\circ}-21^{\prime}-04.16^{\prime \prime}$. Coordinate data were provided by Martin Marietta Energy systems. The method used for conversion from $\mathrm{Y}-12$ grid to TennesseeLambert state Plane Coordinates came from the publication "Tennessee Valley Authority Data Services Branch and Mapping Services Branch, Oak Ridge, Tennessee, DOE Plant Control, November 6, 1985, Field Book: ESS-3115, pp. 120." The latitude and longitude were calculated by Adams Craft Herz walker Engineering, Inc., using methods from the U.S. Coast and Geodetic Survey Publication 62-4, "State Plane Coordinates by Automatic Data Processing."

\subsection{Drilling Information}

Well number 1143 was drilled by Geotek Engineering Company.' An Ingersoll Rand T-4 rig was used to drill this boring for monitor well installation under operation of Larry Ledbetter with the assistance of Fred Dixon. Drilling commenced on 1-23-90 and was finished on 3-6-90. Paragraph 2.4.1 includes a detailed discussion of the well installation and a well schematic is included on the well installation/completion form. A synopsis of the drilling activity follows. This information was typed directly from field notes and was edited only when necessary for clarification. 
1-23-90 The rig was mobilized to the staked location and set up on plastic sheeting. The boring was augered to 6.5 feet using a 22-inch auger. Set 6.5 feet of $151 / 4$-inch decontaminated steel diverter casing and grouted it to surface.

1-24-90 Augered from 6.5 feet to refusal at 27.5 feet using a 14.0-inch auger. Rig up a 14.0-inch air rotary tricone and drill from 27.5 feet to 30.0 feet.

1-25-90 Set 30.0 feet 10 1/4-inch decontaminated steel surface casing with bentonite seal and tremie grouted it to surface with 15 sacks grout. 2-1-90 Rig up and drill from 30.0 feet to 38.0 feet using an 8.0-inch air rotary tricone bit. 2-2-90 Drill from 38.0 feet to total depth at 52.5 feet. Rig down.

3-6-90 Set 4-inch stainless steel well casing and screens with sandpack and bentonite seal.

3-7-90 Tremie grouted well casing annulus with 9.0 sacks of cement.

This well was logged by ERC Environmental and Energy Services Co., Inc., hydrogeologists Bruce Mcmaster and Timothy A. Lee. All well construction materials and supplies were from Martin Marietta Energy Systems approved batches. The batch origin of individual items is shown on the included Monitoring Well Materials Certification form. 


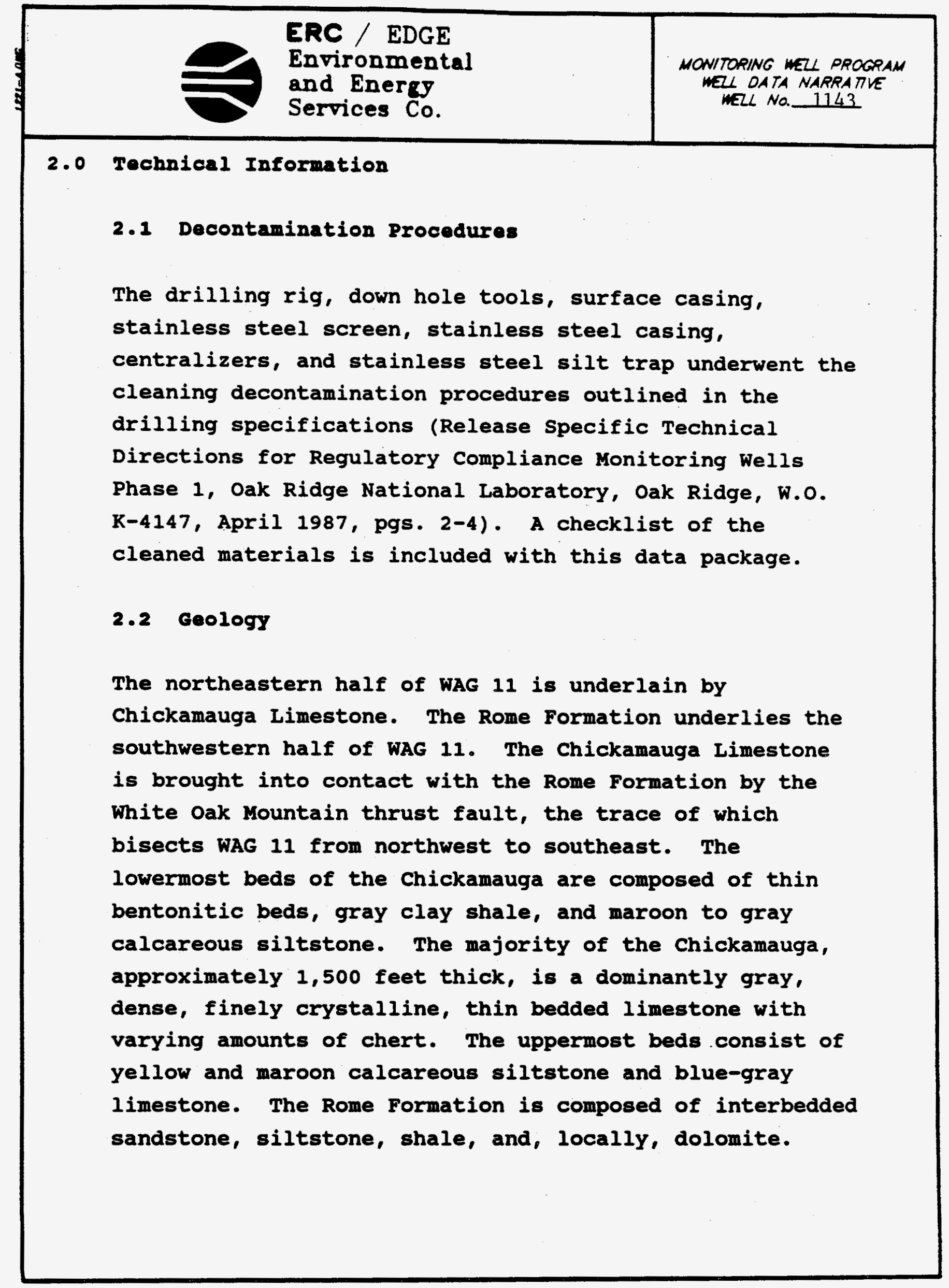




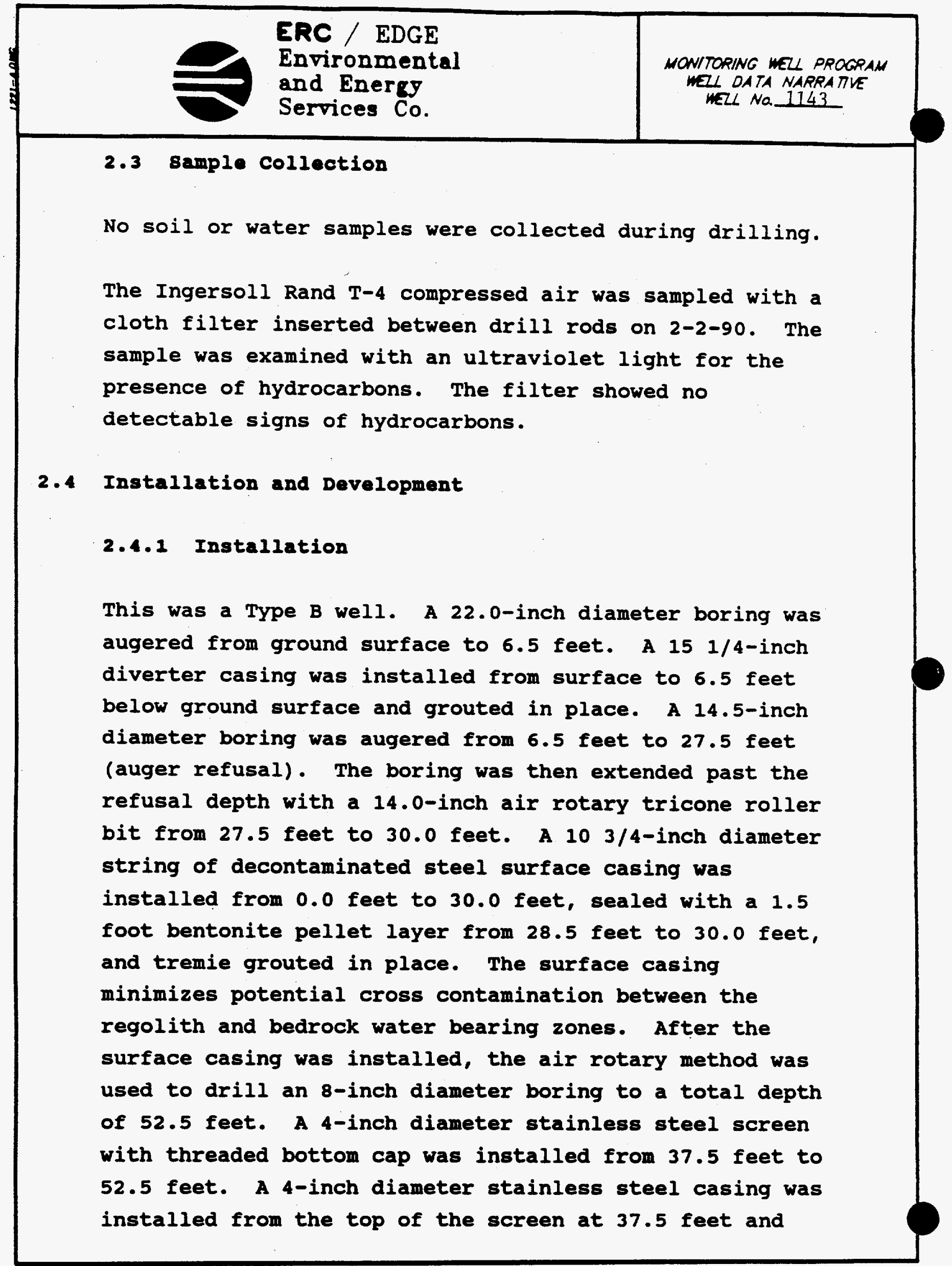


extended 2.5 feet above ground surface. A sandpack was then tremied into the annular space from 30.4 to 52.5 feet, with a 3.6 foot bentonite pellet seal poured into the annular space above the sandpack from 26.8 to 30.4 feet. The annular space from the top of the bentonite seal to the surface was tremie grouted with a cement/bentonite slurry. A detailed schematic of the well is included on the well installation/completion form.

\subsubsection{Well Development}

Well number 1143 was developed to remove drill cuttings, silt, and other fines. The monitoring well was developed using a Geoguard pump with an air compressor. All pumps were cleaned prior to use according to specified cleaning procedures (see Paragraph 2.1). The well was developed until a measured total of 161 gallons of water had been evacuated and the clarity of the discharge water was approved by the company representative. The final turbidity value measured at completion was 4.0 NTU's. A development form showing the exact method of development and other pertinent data is appended.

\subsubsection{Installation of Dodicated Monitoring Nell Pump}

After the well was developed, a Geoguard Model No. 5614 dedicated monitoring well pump was installed on $7 / 27 / 90$ at a depth of 51.5 feet below ground surface. These pumps are decontaminated at American sigma and are sent prepackaged. A copy of the pump certification is kept on file at ORNL. 


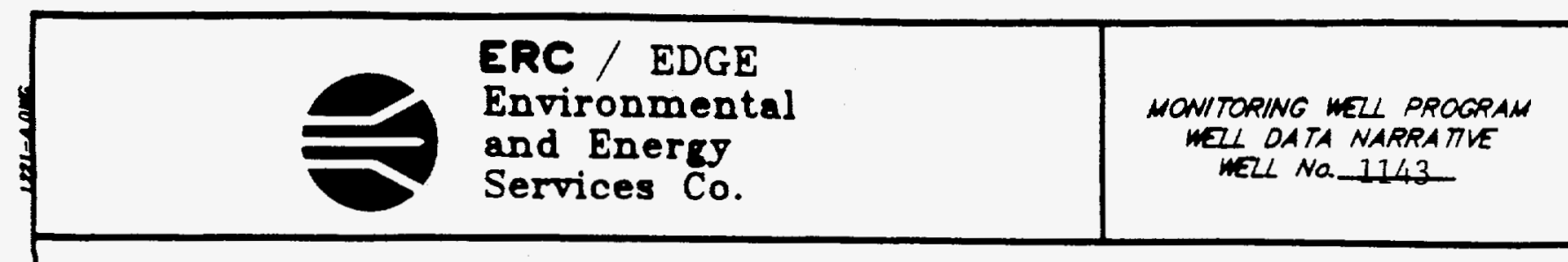

\subsection{Bydraulic Conductivity Testing}

We1l number 1143 was tested for the determination of hydraulic conductivity of the aquifer in the vicinity of the well screen. This was accomplished by instantaneously removing a known quantity of water from the monitoring well and measuring the recovery of the water level over time. The changing water levels were measured using a Druck 15 psi pressure transducer and an Omnidata Datapod II data recorder. The hydraulic conductivity value of $1.45 \times 10^{-4} \mathrm{~cm} / \mathrm{second}$ (shown as permeability on the hydraulic conductivity calculations printout attached) was calculated using the Bouwer and Rice method. A computer printout of the hydraulic conductivity calculations is included in this data package. 
ERC / EDGE

Environmental

and Energy

Services Co.

\subsection{Nell Location}

Monitoring well number 1144 is located in WAG 11 . It is located in the northwestern boundaries of white wing Scrap Yard. The location is shown on ORNL drawing number C3E20004A075. Survey coordinates for this well are N $35,339.3270, E 27,421.6061$ (Y-12 grid) or latitude $35^{\circ}$ $57^{\prime}-05.29^{\prime \prime}$ and longitude 84 $4^{\circ}-21^{\prime}-07.49^{\prime \prime}$. Coordinate data were provided by Martin Marietta Energy systems. The method used for conversion from $Y-12$ grid to TennesseeLambert state Plane coordinates came from the publication "Tennessee Valley Authority Data Services Branch and Mapping Services Branch, Oak Ridge, Tennessee, DOE Plant Control, November 6, 1985, Field Book: Ess-3115, pp. 120." The latitude and longitude were calculated by Adams Craft Herz Walker Engineering, Inc., using methods from the U.S. Coast and Geodetic Survey Publication 62-4, "State Plane Coordinates by Automatic Data Processing."

\subsection{Drilling Information}

Well number 1144 was drilled by Geotek Engineering Company. An Ingersoll Rand $\mathrm{T}-4 \mathrm{rig}$ was used to drill this boring for monitor well installation under operation of Larry Ledbetter with the assistance of Fred Dixon. Drilling commenced on 1-10-90 and was finished on 2-15-90. Paragraph 2.4.1 includes a detailed discussion of the well installation and a well schematic is included on the well installation/completion form. A synopsis of the drilling activity follows. This information was typed directly from field notes and was edited only when necessary for clarification. 
ERC / EDGE

Environmental

and Energy

Services Co.

MONITORING WEZL PROGRAM

WEL OATA NARRATIE

MELL No. 1144

1-10-90 The rig was mobilized to location and set up on plastic sheeting. Split spoon samples were taken from surface to refusal at 39.1 feet. The boring was reamed to 6.0 feet using a $22.0-$ inch auger.

1-11-90 Set and grouted 6.0 feet of 15.0-inch decontaminated steel diverter casing. Moved rig from hole

1-31-90 Moved rig back over hole. Drilled to 44.0 feet using a 14.0-inch air rotary tricone bit.

2-1-90 Set 44.0 feet of 10 3/4-inch decontaminated steel surface casing. Moved rig from location. 2-2-90 Grouted surface casing with 15 sacks cement. 2-15-90 Move back to location. Drill from 44.0 to 122.5 feet using an 8.0-inch air rotary tricone bit. Run stainless steel 4-inch well casing and screen and set with sand pack and bentonite seal.

2-16-90 Grouted well casing annulus with 13 sacks cement.

This well was logged by ERC Environmental and Energy Services Co., Inc., hydrogeologist Timothy A. Lee. All well construction materials and supplies were from Martin Marietta Energy Systems approved batches. The batch origin of individual items is shown on the included Monitoring Well Materials Certification form. 


\subsection{Technical Information}

\subsection{Decontamination Procedurea}

The drilling rig, down hole tools, surface casing, stainless steel screen, stainless steel casing, centralizers, and stainless steel silt trap underwent the cleaning decontamination procedures outlined in the drilling specifications (Release Specific Technical Directions for Regulatory Compliance Monitoring Wells Phase 1, Oak Ridge National Laboratory, Oak Ridge, w.0. K-4147, April 1987, pgs. 2-4). A checklist of the cleaned materials is included with this data package.

\subsection{Geology}

The northeastern half of WAG 11 is underlain by Chickamauga Limestone. The Rome Formation underlies the southwestern half of WAG 11. The Chickamauga Limestone is brought into contact with the Rome Formation by the White Oak Mountain thrust fault, the trace of which bisects WAG 11 from northwest to southeast. The lowermost beds of the Chickamauga are composed of thin bentonitic beds, gray clay shale, and maroon to gray calcareous siltstone. The majority of the Chickamauga, approximately 1,500 feet thick, is a dominantly gray, dense, finely crystalline, thin bedded limestone with varying amounts of chert. The uppermost beds consist of yellow and maroon calcareous siltstone and blue-gray limestone. The Rome Formation is composed of interbedded sandstone, siltstone, shale and locally, dolomite. 


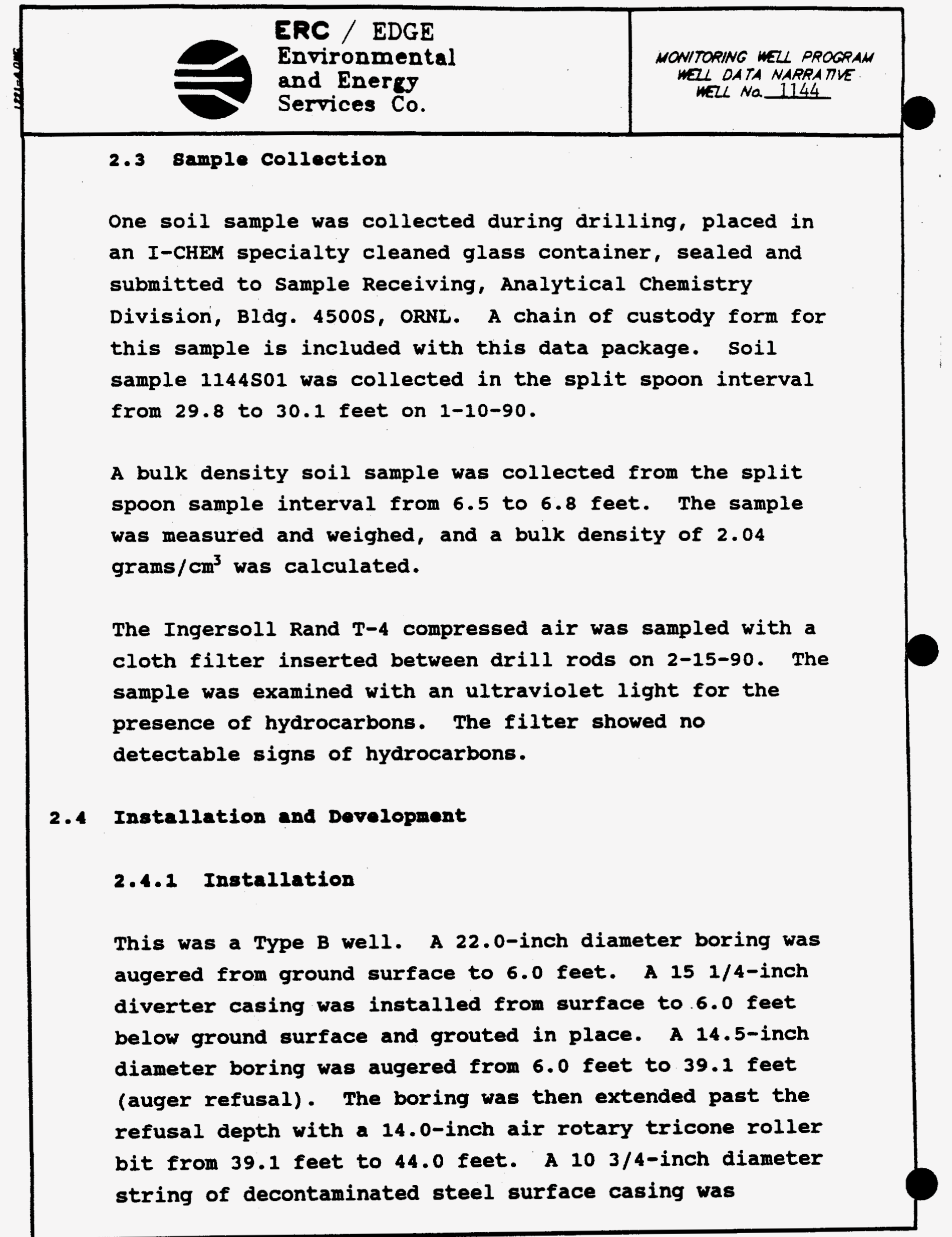


installed from 0.0 feet to 44.0 feet, sealed with a 2.0 foot bentonite pellet layer from 42.0 feet to 44.0 feet, and tremie grouted in place. The surface casing minimizes potential cross contamination between the regolith and bedrock water bearing zones. After the surface casing was installed, the air rotary method was used to drill an 8-inch diameter boring to a total depth of 122.5 feet. A 4-inch diameter stainless steel screen with threaded bottom cap was installed from 102.1 feet to 122.3 feet. A 4-inch diameter stainless steel casing was installed from the top of the screen at 102.1 feet and extended 2.9 feet above ground surface. A sandpack was then tremied into the annular space from 98.5 to 122.3 feet, with a 1.4 foot bentonite pellet seal poured into the annular space above the sandpack from 97.1 to 98.5 feet. The annular space from the top of the bentonite seal to the surface was tremie grouted with a cement/bentonite slurry. A detailed schematic of the well is included on the well installation/completion form.

\subsubsection{We11 Development}

Well number 1144 was developed to remove drill cuttings, silt, and other fines. The monitoring was developed using a Geoguard pump with an air compressor. All pumps were cleaned prior to use according to specified cleaning procedures (see Paragraph 2.1). The well was developed until a measured total of 970 gallons of water had been evacuated and the clarity of the discharge water was approved by the company representative. The final turbidity value measured at completion was 5 NTU's. A development form showing the exact method of development and other pertinent data is appended. 


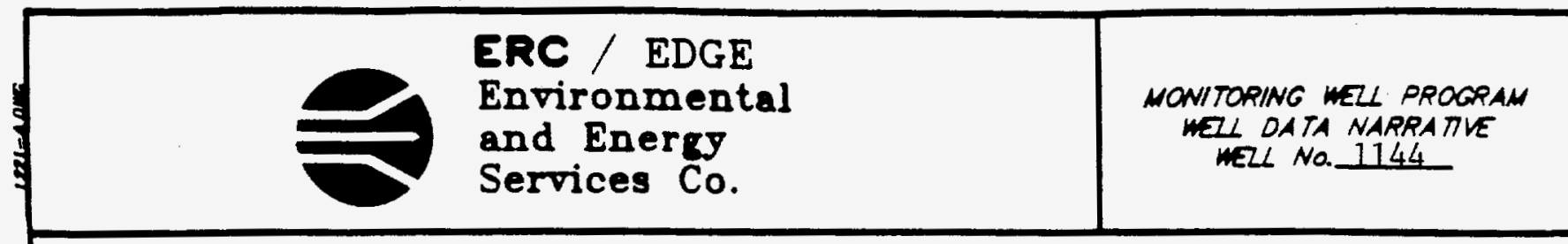

$2 \cdot 4 \cdot 3$ Installation of Dedicated Monitoring Nell Pump

After the well was developed, a Geoguard Model No. 5614 dedicated monitoring well pump was installed on 9-16-90 at a depth of 119.6 feet below ground surface. These pumps are decontaminated at American sigma and are sent prepackaged. A copy of the pump certification is kept on file at ORNL.

\subsection{Hydraulic conductivity Testing}

Well number 1144 was tested for the determination of hydraulic conductivity of the aquifer in the vicinity of the well screen. This was accomplished by instantaneously adding a known quantity of water to the monitoring well and measuring the recovery of the water level over time. The changing water levels were measured using a Druck 15 psi pressure transducer and an Omnidata Datapod II data recorder. The hydraulic conductivity value of $1.58 \times 10^{-6} \mathrm{~cm} /$ second (shown as permeability on the hydraulic conductivity calculations printout attached) was calculated using the Bouwer and Rice method. A computer printout of the hydraulic conductivity calculations is included in this data package. 
ERC / EDGE

Environmental

and Energy

Services Co.
MONITORING WELI PROGRAM

WEL DATA NARRATVE WELL NO. 1145

General Information

\subsection{Well Location}

Monitoring well number 1145 is located in WAG 11. It is located in the northwest boundary of White wing scrap Yard. The location is shown on ORNL drawing number C3E20004A075. Survey coordinates for this well are N $35,589.3486$, E $27,674.9621$ (Y-12 grid) or latitude $35^{\circ}-$ $57^{\prime}-08.74^{\prime \prime}$ and longitude $84^{\circ}-21^{\prime}-06.62^{\prime \prime}$. Coordinate data were provided by Martin Marietta Energy systems. The method used for conversion from $\mathrm{Y}-12$ grid to TennesseeLambert state Plane Coordinates came from the publication "Tennessee Valley Authority Data Services Branch and Mapping Services Branch, Oak Ridge, Tennessee, DOE Plant Control, November 6, 1985, Field Book: EsS-3115, pp. 120." The latitude and longitude were calculated by Adams Craft Herz Walker Engineering, Inc., using methods from the U.S. Coast and Geodetic Survey Publication 62-4, "state Plane Coordinates by Automatic Data Processing."

\subsection{Driliing Information}

Well number 1145 was drilled by Geotek Engineering Company. An Ingersoll Rand T-4 rig was used to drill this boring for monitor well installation under operation of Larry Ledbetter with the assistance of Fred Dixon. Drilling commenced on 1-11-90 and was finished on 1-15-90. Paragraph 2.4.1 includes a detailed discussion of the well installation and a well schematic is included on the well installation/completion form. A synopsis of the drilling activity follows. This information was typed directly from field notes and was edited only when necessary for clarification. 
ERC / EDGE

Environmental

and Enerey

Services Co.

MONITORING WEZL PROORAM

WEZL OATA NARRATIE

WEL NO_ 1145
$1-11-90$

$1-12-90$

$1-15-90$

$1-16-90$

The rig was mobilized to location and set up on plastic sheeting. Split spoon samples were taken from surface to 45.0 feet.

The boring was deepened from 45.0 feet to auger refusal at 59.1 feet using a 6-inch auger. The well was bailed to 58.0 feet.

The boring was bailed to 59.0 feet. Two-inch stainless steel casing and screen was set with sand pack and bentonite seal.

The stainless steel casing was grouted into place with 6 sacks cement.

This well was logged by ERC Environmental and Energy Services Co., Inc., hydrogeologists Timothy $A$. Lee and Michael L. Ebers. All well construction materials and supplies were from Martin Marietta Energy systems approved batches. The batch origin of individual items is shown on the included Monitoring Well Materials Certification form.

\subsection{Technical Information}

\subsection{Decontamination Proceduree}

The drilling rig, down hole tools, surface casing, stainless steel screen, stainless steel casing, centralizers, and stainless steel silt trap underwent the cleaning decontamination procedures outlined in the drilling specifications (Release specific Technical Directions for Regulatory Compliance Monitoring Wells Phase 1, Oak Ridge National Laboratory, Oak Ridge, W.o. K-4147, April 1987, pgs. 2-4). A checklist of the cleaned materials is included with this data package. 
ERC / EDGE

Environmental

and Energy

Services Co.
MONITORING WELL PROGRAN WEIL OATA NARRATVE WELL NO. 1145

\subsection{Geology}

The northeastern half of WAG 11 is underlain by Chickamauga Limestone. The Rome Formation underlies the southwestern half of WAG 11. The Chickamauga Limestone is brought into contact with the Rome Formation by the White oak Mountain thrust fault, the trace of which bisects WAG 11 from northwest to southeast. The lowermost beds of the Chickamauga are composed of thin bentonitic beds, gray clay shale, and maroon to gray calcareous siltstone. The majority of the Chickamauga, approximately 1,500 feet thick, is a dominantly gray, dense, finely crystalline, thin bedded limestone with varying amounts of chert. The uppermost beds consist of yellow and maroon calcareous siltstone and blue-gray limestone. The Rome Formation is composed of interbedded sandstone, siltstone, shale, and, locally, dolomite.

\section{3 sample collection}

Two soil samples were collected during drilling, placed in I-CHEM specialty cleaned glass containers, sealed and submitted to Sample Receiving, Analytical Chemistry Division, Bldg. 4500S, ORNL. Chain of custody forms for these samples are included with this data package. Soil sample 1145501 was collected in the split spoon interval from 20.2 to 20.6 feet on 1-11-90 and soil sample 1145502 was collected in the split spoon interval from 27.8 to 28.4 on $1-11-90$.

A bulk density soil sample was collected from the split spoon sample interval from 10.2 to 10.5 feet. The sample was measured and weighed, and a bulk density of 2.30 grams $/ \mathrm{cm}^{3}$ was calculated. 
ERC / EDGE

Environmental

and Energy

Services Co.
MONITORING WELL PROGRAM WEZL OATA NARRATVE WEZL NO. 1145

\subsection{Installation and Development}

\subsubsection{Installation}

This was a Type A well. A 6-inch diameter boring was split spooned and augered from ground surface to a total depth of 59.1 feet. A 2-inch diameter stainless steel screen with welded bottom cap was installed from 38.0 feet to 59.1 feet. A 2-inch diameter stainless steel casing was installed above the screen from 38.0 feet to 2.0 feet above ground surface. A sandpack was then tremied into the annular space from 36.2 to 59.1 feet, with a 1.1 foot bentonite pellet seal poured into the annular space above the sandpack from 35.1 to 36.2 feet. The annular space from the top of the bentonite seal to the surface was tremie grouted with a cement/bentonite slurry. A detailed schematic of the well is included on the well installation/completion form.

\section{4 .2 Dell Development}

Well number 1145 was developed to remove drill cuttings, silt, and other fines. The monitoring well was developed using a Geoguard pump with an air compressor. All pumps were cleaned prior to use according to specified cleaning procedures (see Paragraph 2.1). The well was developed until a measured total of 331 gallons of water had been evacuated and the clarity of the discharge water was approved by the company representative. The final turbidity value measured at completion was $>100$ NTU's. A development form showing the exact method of development and other pertinent data is appended. 
ERE / EDGE

Environmental

and Energy Services Co.
MONITORING WELL PROGRAM WEI DATA NARRATE NELL NO. 1145

2.4.3 Installation of Dedicated Monitoring Nell Pump

After the well was developed, a Geoguard Model No. 5614 dedicated monitoring well pump was installed on 8-2-90 at a depth of 58.3 feet below ground surface. These pumps are decontaminated at American sigma and are sent prepackaged. A copy of the pump certification is kept on file at ORNL.

2.5 Hydraulic Conductivity Testing

Well number 1145 was not tested for hydraulic conductivity. The water level in the well was too low for a falling head test. A stainless steel slug would not pass by a tight spot in the well screen thus prohibiting a rising head test.

PAGE 5 OF 16 
1.0 General Information

\subsection{Well Location}

Monitoring well number 1146 is located in WAG 11. It is located in the northwestern portion of White wing scrap Yard. The location is shown on ORNL drawing number C3E20004A075. Survey coordinates for this well are N $35,704.1986$, E $28,337.7057$ (Y-12 grid) or latitude $35^{\circ}-$ $57^{\prime}-13.33^{\prime \prime}$ and longitude 84 $4^{\circ}-21^{\prime}-00.70^{\prime \prime}$. Coordinate data were provided by Martin Marietta Energy systems. The method used for conversion from $\mathrm{Y}-12$ grid to TennesseeLambert state Plane Coordinates came from the publication "Tennessee Valley Authority Data Services Branch and Mapping Services Branch, Oak Ridge, Tennessee, DOE Plant Control, November 6, 1985, Field Book: ESS-3115, pp. 120." The latitude and longitude were calculated by Adams Craft Herz Walker Engineering, Inc., using methods from the U.S. Coast and Geodetic Survey Publication 62-4, "state Plane Coordinates by Automatic Data Processing."

\subsection{Drilling Information}

Well number 1146 was drilled by Geotek Engineering Company. An Ingersoll Rand T-4 rig was used to drill this boring for monitor well installation under operation of Larry Ledbetter with the assistance of Fred Dixon. Drilling commenced on 1-5-90 and was finished on 2-27-90. Paragraph 2.4.1 includes a detailed discussion of the well installation and a well schematic is included on the 
well installation/completion form. A synopsis of the drilling activity follows. This information was typed directly from field notes and was edited only when necessary for clarification.

1-4-90 The rig was mobilized to location and set up on plastic sheeting.

1-5-90 Split spoon samples were taken from surface to refusal at 38.0 feet. The boring was augered to 28.0 feet with a 14.0 -inch auger.

1-8-90 Set 10 3/4-inch decontaminated steel diverter casing at 28.0 feet with a 2.0 feet bentonite pellet seal. The rig was moved from location. The casing annulus was grouted with 10 sacks cement.

2-22-90 Move rig to location and drill to 62.5 feet with an 8.0-inch air rotary tricone bit.

2-23-90 Drill to 122.5 feet with 8.0-inch air rotary tricone bit.

2-26-90 The well was deepened from 122.5 feet to 132.5 feet. Ran 4.0-inch stainless steel casing which stopped at 121.0 feet. Decided to pull casing and redrill hole.

2-27-90 Re-drill hole with 8.0-inch air rotary tricone bit to 132.5 feet. After pulling drill steel out of hole, weighted tape showed total depth of hole at 118.0 feet. Decide to run 4.0-inch stainless steel casing to 117.3 feet and set it with sand pack and bentonite pellet seal. The rig was moved from location.

2-28-90 Tremie grouted annulus with 25 sacks cement with flocele.* 


$\begin{array}{ll}\text { 3-2-90 } & \text { Tremie grouted annulus with } 27 \text { more sacks } \\ \text { cement with flocele. } & \text { 3remie grouted annulus with } 12 \text { more sacks } \\ & \text { cement with flocele. } \\ 3-7-90 & \text { Tremie grouted annulus with } 1 \text { more sack cement } \\ & \text { to surface. }\end{array}$

* After the stainless steel casing was set with sandpack and bentonite seal, 30.0 feet of P.V.C. tremie pipe was dropped into the annulus of this well. After a few attempts to "fish", this pipe was encapsulated in the grout.

This well was logged by ERC Environmental and Energy Services Co., Inc., hydrogeologist Timothy A. Lee. All well construction materials and supplies were from Martin Marietta Energy Systems approved batches. The batch origin of individual items is shown on the included Monitoring Well Materials Certification form.

\subsection{Technical Information}

\subsection{Decontamination Procedures}

The drilling rig, down hole tools, surface casing, stainless steel screen, stainless steel casing, centralizers, and stainless steel silt trap underwent the cleaning decontamination procedures outlined in the drilling specifications (Release Specific Technical Directions for Regulatory Compliance Monitoring Wells Phase 1, Oak Ridge National Laboratory, Oak Ridge, w.o. 
K-4147, April 1987, pgs. 2-4). A checklist of the cleaned materials is included with this data package.

\subsection{Geology}

The northeastern half of WAG 11 is underlain by Chickamauga Limestone. The Rome Formation underlies the southwestern half of WAG 11 . The Chickamauga Limestone is brought into contact with the Rome Formation by the White Oak Mountain thrust fault, the trace of which bisects WAG 11 from northwest to southeast. The lowermost beds of the chickamauga are composed of thin bentonitic beds, gray clay shale, and maroon to gray calcareous siltstone. The majority of the chickamauga, approximately 1,500 feet thick, is a dominantly gray, dense, finely crystalline, thin bedded limestone with varying amounts of chert. The uppermost beds consist of yellow and maroon calcareous siltstone and blue-gray limestone. The Rome Formation is composed of interbedded sandstone, siltstone, shale, and, locally, dolomite.

\subsection{Sample collection}

One soil sample was collected during drilling, placed in an I-CHEM specialty cleaned glass container, sealed and submitted to Sample Receiving, Analytical Chemistry Division, Bldg. 4500S, ORNL. A chain of custody form for this sample is included with this data package. Soil sample 1146501 was collected in the split spoon interval from 37.0 to 38.0 feet on 1-5-90. 
A bulk density soil sample was collected from the split spoon sample interval from $4.1^{\prime}$ to $4.5 '$. The sample was measured, weighed and a bulk density of $1.74 \mathrm{grams} / \mathrm{cm}^{3}$ was calculated.

The Ingersoll Rand T-4 compressed air was sampled with a cloth filter inserted between drill rods on 2-26-90. The sample was examined with an ultraviolet light for the presence of hydrocarbons. The filter showed no detectable signs of hydrocarbons.

\subsection{Installation and Development}

\subsubsection{Installation}

This was a Type B well. A 14.0-inch diameter boring was augered from surface to 28.0 feet. A 10 3/4-inch diameter string of decontaminated steel surface casing was installed from 0.0 feet to 28.0 feet, sealed with a 2.0 foot bentonite pellet layer from 26.0 feet to 28.0 feet, and tremie grouted in place. The surface casing minimizes potential cross contamination between the regolith and bedrock water bearing zones. After the surface casing was installed, the air rotary method was used to drill an 8-inch diameter boring to a total depth of 132.5 feet. A 4-inch diameter stainless steel screen with threaded bottom cap was installed from 107.1 feet to 117.3 feet. A 4-inch diameter stainless steel casing was installed from the top of the screen at 107.1 feet and extended 2.9 feet above ground surface. A sandpack was then tremied into the annular space from 103.8 to 117.3 
ERC / EDGE

Environmental

and Enerey

Services Co.

feet, with a 1.4 foot bentonite pellet seal poured into the annular space above the sandpack from 102.4 to 103.8 feet. The annular space from the top of the bentonite seal to the surface was tremie grouted with a cement/bentonite slurry. A detailed schematic of the well is included on the well installation/ completion form.

\subsubsection{Well Development}

Well number 1146 was developed to remove drill cuttings, silt, and other fines. The monitoring well was developed using a Geoguard pump with an air compressor. All pumps were cleaned prior to use according to specified cleaning procedures (see Paragraph 2.1). The well was developed until a measured total of 501 gallons of water had been evacuated and the clarity of the discharge water was approved by the company representative. The final turbidity value measured at completion was 2.0 NTU's. A development form showing the exact method of development and other pertinent data is appended.

\subsubsection{Installation of Dedicated Monitoring well Pump}

After the well was developed, a Geoguard Model No. 5614 dedicated monitoring well pump was installed on $8 / 9 / 90$ at a depth of 112.0 feet below ground surface. These pumps are decontaminated at American Sigma and are sent prepackaged. A copy of the pump certification is kept on file at ORNL. 


\subsection{Hydraulic conductivity Testing}

Well number 1146 was tested for the determination of hydraulic conductivity of the aquifer in the vicinity of the well screen. This was accomplished by instantaneously adding a known quantity of water to the monitoring well and measuring the recovery of the water level over time. The changing water levels were measured using a Druck 15 psi pressure transducer and an Omnidata Datapod II data recorder. The hydraulic conductivity value of $1.06 \times 10^{-4} \mathrm{~cm} / \mathrm{second}$ (shown as permeability on the hydraulic conductivity calculations printout attached) was calculated using the Bouwer and Rice method. A computer printout of the hydraulic conductivity calculations is included in this data package. 
ERC / EDGE

Environmental

and Energy

Services Co.
MONITORING WELL PROGPAM

WEII DATA NARRATVE

WRL NO. 1147

\subsection{General Information}

\section{1 well Location}

Monitoring well number 1147 is located in WAG 11. It is located in the northeastern portion of White wing Scrap Yard. The location is shown on ORNL drawing number C3E20004A075. Survey coordinates for this well are $N$ $35,696.4970, \mathrm{E} 28,354.4126(\mathrm{Y}-12 \mathrm{grid})$ or latitude $35^{\circ}-$ $57^{\prime}-13.36^{\prime \prime}$ and longitude $84^{\circ}-21^{\prime}-00.48^{\prime \prime}$. Coordinate data were provided by Martin Marietta Energy Systems. The method used for conversion from $\mathrm{Y}-12$ grid to TennesseeLambert state Plane coordinates came from the publication "Tennessee Valley Authority Data Services Branch and Mapping Services Branch, Oak Ridge, Tennessee, DOE Plant Control, November 6, 1985, Field Book: ESS-3115, pp. 120." The latitude and longitude were calculated by Adams Craft Herz Walker Engineering, Inc., using methods from the U.S. Coast and Geodetic Survey Publication 62-4, "state Plane Coordinates by Automatic Data Processing."

\subsection{Drilling Information}

Well number 1147 was drilled by Geotek Engineering Company. An Ingersoll Rand T-4 rig was used to drill this boring for monitor well installation under operation of Larry Ledbetter with the assistance of Fred Dixon. Drilling commenced on 1-4-90 and was finished on 1-29-90. Paragraph 2.4.1 includes a detailed discussion of the well installation and a well schematic is included on the well installation/completion form. A synopsis of the drilling activity follows. This information was typed directly from field notes and was edited only when necessary for clarification. 
Mobilize rig to staked location and set up on plastic sheeting. Augered from surface to 7.0 feet using a 22.0-inch auger. Set 6.0 feet of 14.0-inch decontaminated steel diverter casing. The rig was moved from location.

1-5-90 The diverter casing was grouted with 5 sacks cement.

1-8-90 The rig moved over hole and augered to refusal at 39.5 feet with a 14.5 -inch auger.

1-9-90 The boring was deepened from 39.5 feet to 45.8 feet using air rotary method with a 14.5-inch air rotary tricone bit. Set 45.8 feet of 10 3/4-inch decontaminated steel surface casing and sealed with bentonite seal. Move rig from location.

1-10-90 Grouted surface casing annulus with 10 sacks of cement.

1-25-90 Move rig over hole.

1-26-90 Deepened boring from 45.8 feet to 97.9 feet using an 8.0-inch air rotary tricone bit.

1-29-90 Set stainless steel 4-inch screen and casing with sand pack and bentonite seal.

1-30-90 Grouted well casing with 19 sacks cement.

This well was logged by ERC Environmental and Energy Services Co., Inc., hydrogeologist Timothy A. Lee. All well construction materials and supplies were from Martin Marietta Energy Systems approved batches. The batch origin of individual items is shown on the included Monitoring Well Materials Certification form. 
2.0 Technical Information

\subsection{Decontamination Procedures}

The drilling rig, down hole tools, surface casing, stainless steel screen, stainless steel casing, centralizers, and stainless steel silt trap underwent the cleaning decontamination procedures outlined in the drilling specifications (Release specific Technical Directions for Regulatory Compliance Monitoring Wells Phase 1, Oak Ridge National Laboratory, Oak Ridge, W.O. K-4147, April 1987, pgs. 2-4). A checklist of the cleaned materials is included with this data package.

\subsection{Geology}

The northeastern half of WAG 11 is underlain by Chickamauga Limestone. The Rome Formation underlies the southwestern half of WAG 11. The Chickamauga Iimestone is brought into contact with the Rome Formation by the White Oak Mountain thrust fault, the trace of which bisects WAG 11 from northwest to southeast. The lowermost beds of the Chickamauga are composed of thin bentonitic beds, gray clay shale, and maroon to gray calcareous siltstone. The majority of the chickamauga, approximately 1,500 feet thick, is a dominantly gray, dense, finely crystalline, thin bedded limestone with varying amounts of chert. The uppermost beds.consist of yellow and maroon calcareous siltstone and blue-gray limestone. The Rome Formation is composed of interbedded sandstone, siltstone, shale, and, locally, dolomite. 


\subsection{Sample collection}

One soil sample was collected during drilling, placed in an I-CHEM specialty cleaned glass container, sealed and submitted to Sample Receiving, Analytical Chemistry Division, Bldg. 4500S, ORNL. A chain of custody form for this sample is included with this data package. Soil sample 1139501 was collected in the split spoon interval from 6.2 to 6.5 feet on 1-19-90.

A drill water sample was collected from the water pump on the drill rig on 1-29-90. Analytical results for the Ingersoll Rand T-4 drill water samples described above can be obtained from the Remedial Action Program data base at ORNL.

The Ingersoll Rand T-4 compressed air was sampled with a cloth filter inserted between drill rods on 1-29-90. The sample was examined with an ultraviolet light for the presence of hydrocarbons. The filter showed no detectable signs of hydrocarbons.

\subsection{Installation and Development}

\subsubsection{Installation}

This was a Type B well. A 22.0-inch diameter boring was augered from ground surface to 6.0 feet. A 15 1/4-inch diverter casing was installed from surface to 6.0 feet below ground surface and grouted in place. A 14.0-inch diameter boring was augered from 6.0 feet to 39.5 feet (auger refusal). The boring was then extended past the refusal depth with a 14.0-inch air rotary tricone roller bit from 0.0 feet to 45.8 feet.

A 10.0-inch diameter 
ERC / EDGE

Environmental

and Enerey

Services Co.
MONITORING WELL PROCRAN

WEL DATA NARRATVE

WEL No.1147

string of decontaminated steel surface casing was installed from 0.0 feet to 45.8 feet, sealed with a 2.0 foot bentonite pellet layer from 43.8 feet to 45.8 feet, and tremie-grouted in place. The surface casing minimizes potential cross contamination between the regolith and bedrock water bearing zones. After the surface casing was installed, the air rotary method was used to drill an 8-inch diameter boring to a total depth of 97.9 feet. A 4-inch diameter stainless steel screen with threaded bottom cap was installed from 77.7 feet to 97.9 feet. A 4-inch diameter stainless steel casing was installed from the top of the screen at 7.77 feet and extended 2.2 feet above ground surface. A sandpack was then tremied into the annular space from 73.5 to 97.9 feet, with a 1.3-foot bentonite pellet seal poured into the annular space above the sandpack from 72.2 to 73.5 feet. The annular space from the top of the bentonite seal to the surface was tremie-grouted with a cement/bentonite slurry. A detailed schematic of the well is included on the well installation/completion form.

\section{4 .2 We11 Development}

Well number 1147 was developed to remove drill cuttings, silt, and other fines. The monitoring well was developed using a Geoguard pump with an air compressor. All pumps were cleaned prior to use according to specified cleaning procedures (see Paragraph 2.1). The well was developed until a measured total of 550 gallons of water had been evacuated and the clarity of the discharge water was approved by the company representative. The final 


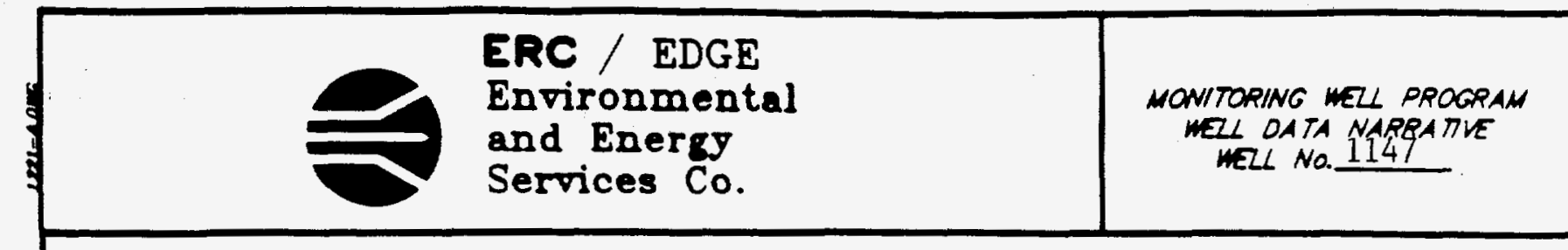

turbidity value measured at completion was 1.0 NTU's. A development form showing the exact method of development and other pertinent data is appended.

\subsubsection{Installation of Dedicated Monitoring Nell Pump}

After the well was developed, a Geoguard Model No. 5614 dedicated monitoring well pump was installed on $8 / 10 / 90$ at a depth of 93.3 feet below ground surface. These pumps are decontaminated at American sigma and are sent prepackaged. A copy of the pump certification is kept on file at ORNL.

\subsection{Hydraulic conductivity Testing}

Well number 1147 was tested for the determination of hydraulic conductivity of the aquifer in the vicinity of the well screen. This was accomplished by instantaneously removing a known quantity of water from the monitoring well and measuring the recovery of the water level over time. The changing water levels were measured using a Druck $15 \mathrm{psi}$ pressure transducer and an Omnidata Datapod II data recorder. The hydraulic conductivity value of $9.18 \times 10^{-5} \mathrm{~cm} / \mathrm{second}$ (shown as permeability on the hydraulic conductivity calculations printout attached) was calculated using the Bouwer and Rice method. A computer printout of the hydraulic conductivity calculations is included in this data package. 


\subsection{General Information}

\subsection{Well Location}

Monitoring well number 1148 is located in WAG 11. It is located in the southwest portion of white wing scrap Yard. The location is shown on ORNL drawing number C3E20004A075. Survey coordinates for this well are N 35,000.4186, E 29,698.6994 (Y-12 grid) or latitude $35^{\circ}-57^{\prime}-15.04^{\prime \prime}$ and longitude $84^{\circ}-20^{\prime}-42.18^{\prime \prime}$. Coordinate data were provided by Martin Marietta Energy systems. The method used for conversion from $\mathrm{Y}-12$ grid to Tennessee-Lambert State Plane coordinates came from the publication "Tennessee Valley Authority Data Services Branch and Mapping Services Branch, Oak Ridge, Tennessee, DOE Plant Control, November 6, 1985, Field Book: ESS-3115, pp. 1-20." The latitude and longitude were calculated by Adams Craft Herz walker Engineering, Inc., using methods from the U.S. Coast and Geodetic survey Publication 62-4, "state Plane coordinates by Automatic Data Processing."

\subsection{Drilling Information}

Well number 1148 was drilled by Geotek Engineering Company. An Ingersoll Rand T-4 rig was used to drill this boring for monitor well installation under operation of Larry Ledbetter with the assistance of Fred Dixon. Drilling commenced on 1-16-90 and was finished on 3-1-90. Paragraph 2.4.1 includes a detailed discussion of the well installation and a well schematic is included on the well installation/completion form. A synopsis of the 


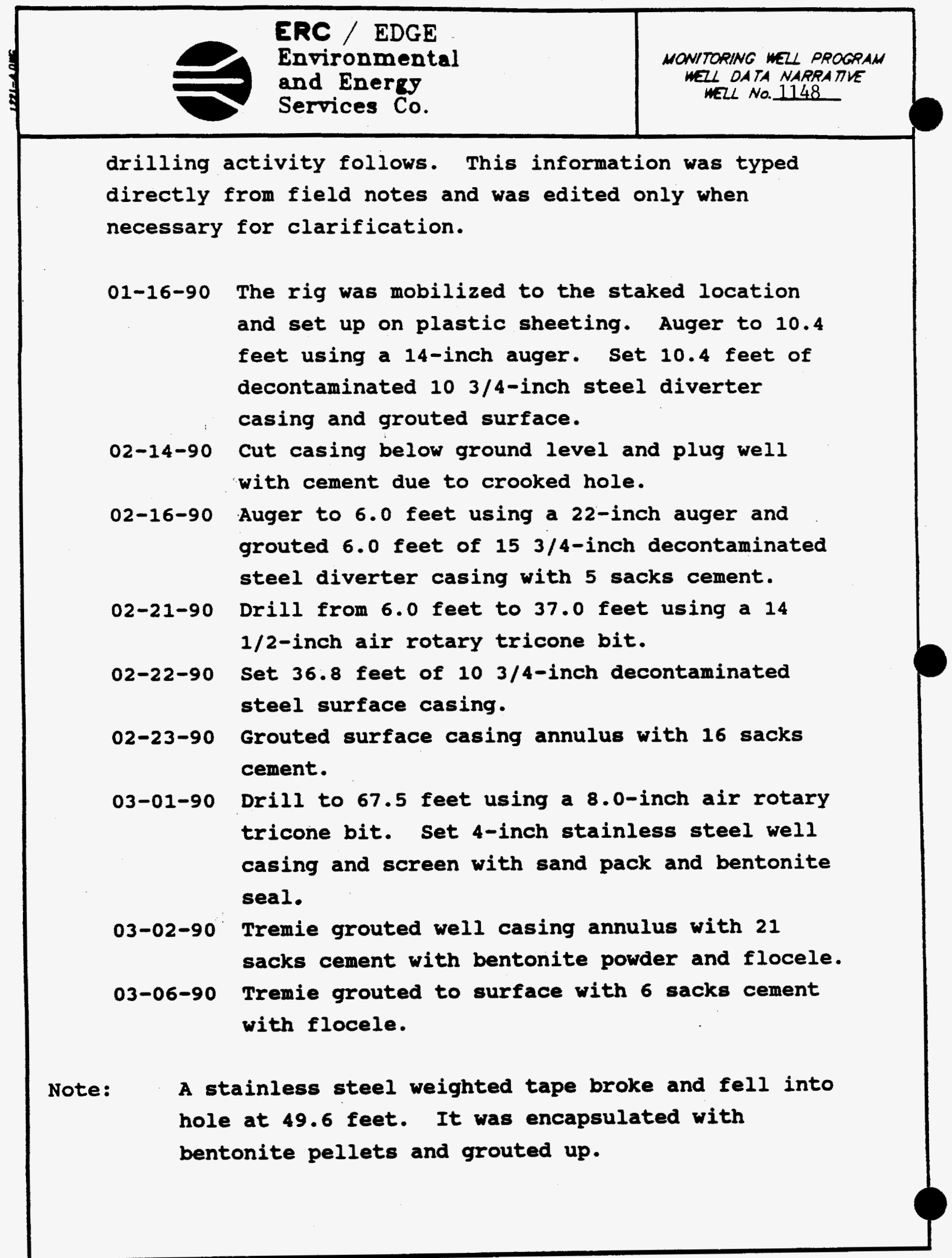


ERC / EDGE

Environmental

and Energy

Services Co.
WONITORING WELL PROARAM WEL DATA NARRATVE

WEL No. 1148

This well was logged by ERC Environmental and Energy

Services Co., Inc., hydrogeologist Timothy A. Lee. All

well construction materials and supplies were from Martin

Marietta Energy Systems approved batches. The batch

origin of individual items is shown on the included

Monitoring Well Materials Certification form.

\subsection{Technical Information}

\subsection{Decontamination Procedures}

The drilling rig, down hole tools, surface casing, stainless steel screen, stainless steel casing, centralizers, and stainless steel silt trap underwent the cleaning decontamination procedures outlined in the drilling specifications (Release specific Technical Directions for Regulatory Compliance Monitoring Wells Phase 1, Oak Ridge National Laboratory, Oak Ridge, w.o. K-4147, April 1987, pgs. 2-4). A checklist of the cleaned materials is included with this data package.

\section{$2.2600109 y$}

The northeastern half of WAG 11 is underlain by Chickamauga Limestone. The Rome Formation underlies the southwestern half of WAG 11. The Chickamauga Limestone is brought into contact with the Rome Formation by the White Oak Mountain thrust fault, the trace of which bisects WAG 11 from northwest to southeast. The lowermost beds of the Chickamauga are composed of thin bentonitic beds, gray clay shale, and maroon to gray calcareous siltstone. The majority of the Chickamauga, approximately 1,500 feet thick, is a dominantly gray, dense, finely crystalline, thin bedded limestone with 


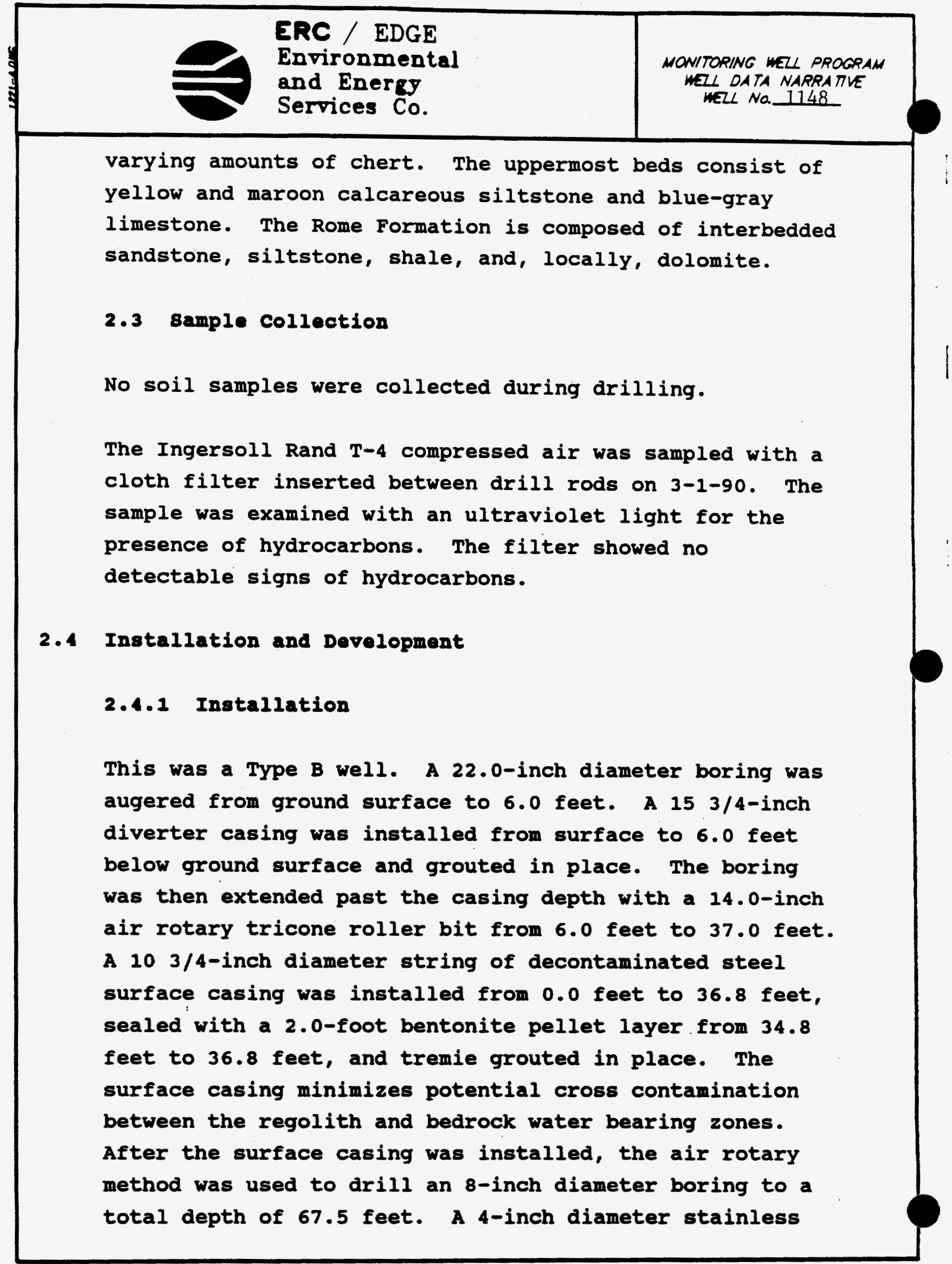


steel screen with threaded bottom cap was installed from 52.2 feet to 67.5 feet. A 4-inch diameter stainless steel casing was installed from the top of the screen at 52.2 feet and extended 2.8 feet above ground surface. A sandpack was then tremied into the annular space from 49.6 to 67.5 feet, with a 2.1-foot bentonite pellet seal poured into the annular space above the sandpack from 47.5 to 49.6 feet. The annular space from the top of the bentonite seal to the surface was tremie grouted with a cement/bentonite slurry. A detailed schematic of the well is included on the well installation/completion form.

\subsection{2 ne11 Development}

Well number 1148 was developed to remove drill cuttings, silt, and other fines. The monitoring well was developed using a Geoguard pump with an air compressor. All pumps were cleaned prior to use according to specified cleaning procedures (see Paragraph 2.1). The well was developed until a measured total of 207 gallons of water had been evacuated and the clarity of the discharge water was approved by the company representative. The final turbidity value measured at completion was $2.0 \mathrm{NTU}$ 's. A development form showing the exact method of development and other pertinent data is appended.

2.4.3 Installation of Dedicated Konitoring well Pump

After the well was developed, a Geoguard Model No. 5614 dedicated monitoring well pump was installed on $7 / 30 / 90$ at a depth of 65.8 feet below ground surface. These 


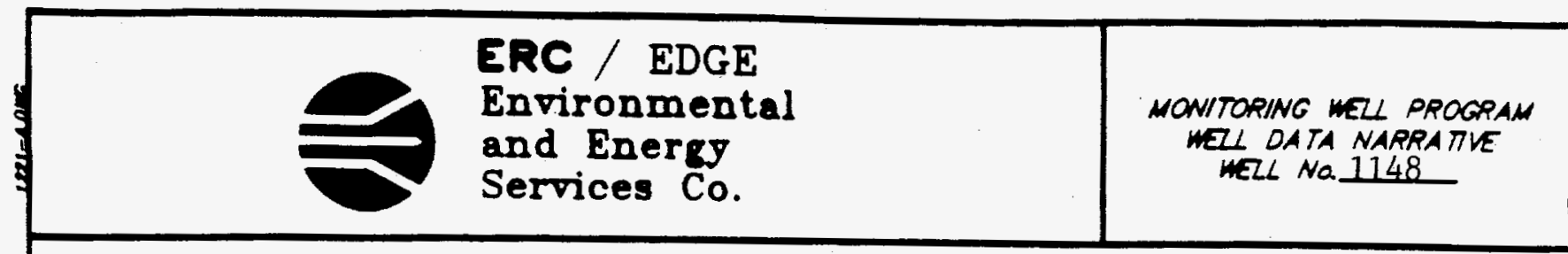

pumps are decontaminated at American sigma and are sent prepackaged. A copy of the pump certification is kept on file at ORNL.

\subsection{Hydraulic Conductivity resting}

Well number 1148 was tested for the determination of hydraulic conductivity of the aquifer in the vicinity of the well screen. This was accomplished by instantaneously adding a known quantity of water to the monitoring well and measuring the recovery of the water level over time. The changing water levels were measured using a Druck 15 psig pressure transducer and an Omnidata Datapod II data recorder. The hydraulic conductivity value of $1.40 \times 10^{-4} \mathrm{~cm} /$ second (shown as permeability on the hydraulic conductivity calculations printout attached) was calculated using the Bouwer and Rice method. A computer printout of the hydraulic conductivity calculations is included in this data package. 
ERC / EDGE

Environmental

and Energy

Services Co.

\subsection{Well Location}

Monitoring well number 1149 is located in WAG 11. It is located in the southwestern portion of White wing scrap Yard. The location is shown on ORNL drawing number C3E20004A075. Survey coordinates for this well are $N$ $34,973.5615, E 29,702.2786$ (Y-12 grid) or latitude $35^{\circ}-57^{\prime}-14.83^{\prime \prime}$ and longitude $84^{\circ}-20^{\prime}-41.96^{\prime \prime}$. Coordinate data were provided by Martin Marietta Energy Systems. The method used for conversion from $Y-12$ grid to Tennessee-Lambert state Plane Coordinates came from the publication "Tennessee Valley Authority Data Services Branch and Mapping Services Branch, Oak Ridge, Tennessee, DOE Plant Control, November 6, 1985, Field Book: Ess-3115, pp. 1-20." The latitude and longitude were calculated by Adams Craft Herz Walker Engineering, Inc., using methods from the U.S. Coast and Geodetic Survey Publication 62-4, "state Plane Coordinates by Automatic Data Processing."

\subsection{Drilling Information}

Well number 1149 was drilled by Geotek Engineering Company. An Ingersoll Rand $\mathrm{T}-4 \mathrm{rig}$ was used to drill this boring for monitor well installation under operation of Larry Ledbetter with the assistance of Fred Dixon. Drilling commenced on 1-16-90 and was finished on 3-1-90. Paragraph 2.4.1 includes a detailed discussion of the well installation and a well schematic is included on the well installation/completion form. A synopsis of the 


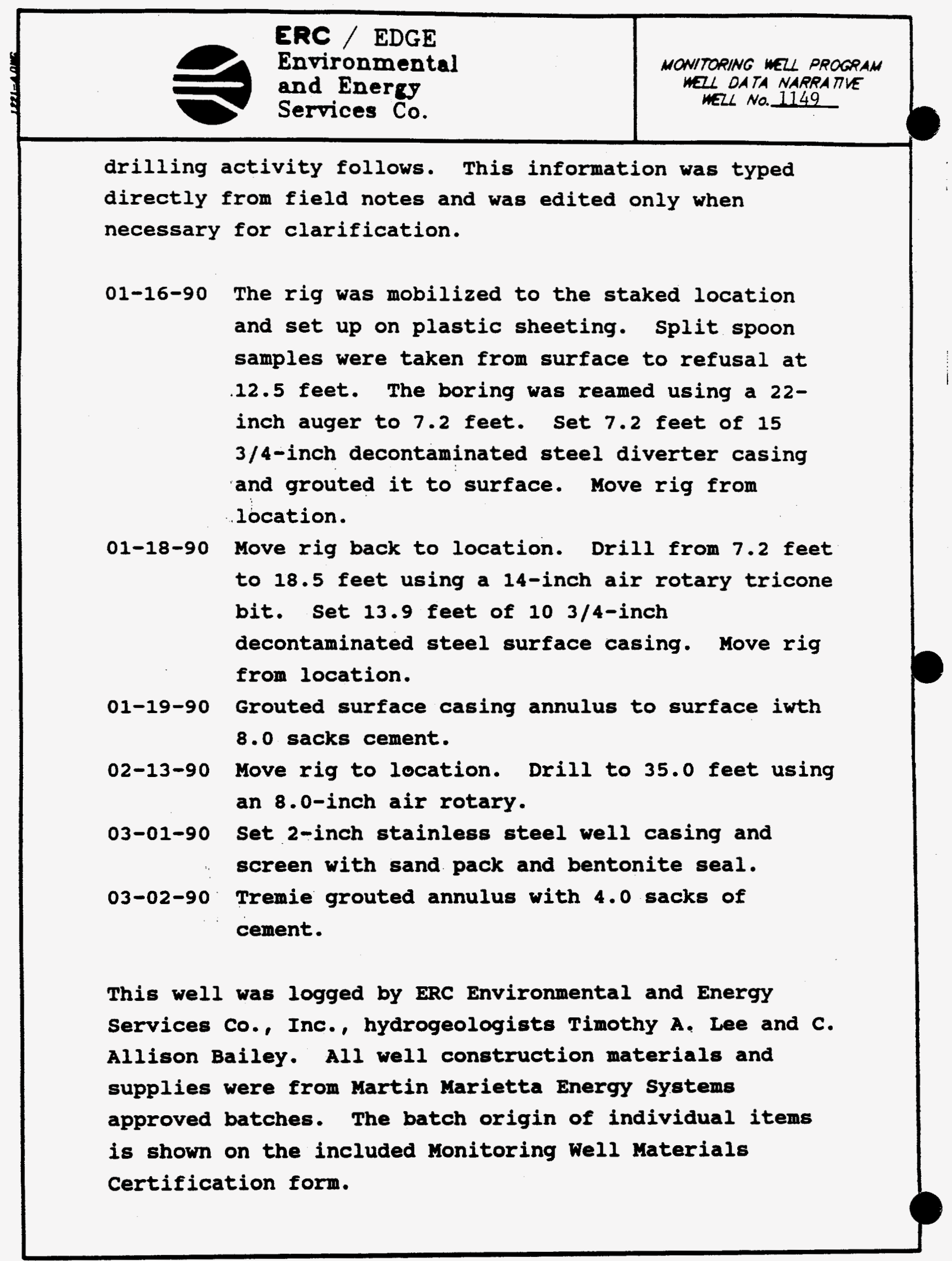

drilling activity follows. This information was typed directly from field notes and was edited only when necessary for clarification.

01-16-90 The rig was mobilized to the staked location and set up on plastic sheeting. split spoon samples were taken from surface to refusal at inch auger to 7.2 feet. Set 7.2 feet of 15 3/4-inch decontaminated steel diverter casing and grouted it to surface. Move rig from location. to 18.5 feet using a 14-inch air rotary tricone bit. Set 13.9 feet of $103 / 4$-inch decontaminated steel surface casing. Move rig cation. 8.0 sacks cement. 8.0-inch air rotary. screen with sand pack and bentonite seal. cement.

This well was logged by ERC Environmental and Energy Services Co., Inc., hydrogeologists Timothy A. Lee and C. Allison Bailey. All well construction materials and supplies were from Martin Marietta Energy Systems is shown on the included Monitoring Well Materials 


\subsection{Technical Information}

\subsection{Decontamination Procedures}

The drilling rig, down hole tools, surface casing, stainless steel screen, stainless steel casing, centralizers, and stainless steel silt trap underwent the cleaning decontamination procedures outlined in the drilling specifications (Release specific Technical Directions for Regulatory Compliance Monitoring Wells Phase 1, Oak Ridge National Laboratory, Oak Ridge, W.0. K-4147, April 1987, pgs. 2-4). A checklist of the cleaned materials is included with this data package.

\section{$2.2600109 y$}

The northeastern half of WAG 11 is underlain by Chickamauga Limestone. The Rome Formation underlies the southwestern half of WAG 11. The Chickamauga Limestone is brought into contact with the Rome Formation by the White oak Mountain thrust fault, the trace of which bisects WAG 11 from northwest to southeast. The lowermost beds of the Chickamauga are composed of thin bentonitic beds, gray clay shale, and maroon to gray calcareous siltstone. The majority of the Chickamauga, approximately 1,500 feet thick, is a dominantly gray, dense, finely crystalline, thin bedded limestone with varying amounts of chert. The uppermost beds consist of yellow and maroon calcareous siltstone and blue-gray limestone. The Rome Formation is composed of interbedded sandstone, siltstone, shale and locally, dolomite. 


\subsection{Sample collection}

One soil sample was collected during drilling, placed in an I-CHEM specialty cleaned glass container, sealed and submitted to Sample Receiving, Analytical Chemistry Division, Bldg. 4500S, ORNL. A chain of custody form for this sample is included with this data package. Soil sample 1149501 was collected in the split spoon interval from 10.3 feet to 10.7 feet on $1-16-90$.

A bulk density soil sample was collected from the split spoon sample interval from 10.3 to 10.7 feet. The sample was measured and weighed, and $a$ bulk density of 1.78 grams $/ \mathrm{cm}^{3}$ was calculated.

The Ingersoll Rand T-4 compressed air was sampled with a cloth filter inserted between drill rods on 2-13-90. The sample was examined with an ultraviolet light for the presence of hydrocarbons. The filter showed no detectable signs of hydrocarbons.

\subsection{Installation and Dovelopment}

\subsubsection{Installation}

This was a Type B well. A 22.0-inch diameter boring was augered from ground surface to 7.2 feet. A 15 3/4-inch diverter casing was installed from surface to.7.2 feet below ground surface and grouted in place. The boring was then extended past the diverter casing depth with a 14.0-inch air rotary tricone roller bit from 7.2 feet to 18.5 feet. A 10 3/4-inch diameter string of decontaminated steel surface casing was installed from 0.0 feet to 13.9 feet, sealed with a 2.0 -foot bentonite 
ERC / EDGE

Environmental

and Energy

Services Co.
MONITORING WEL PROGRAM

WEZL DATA NARPATVE

pellet layer from 11.9 feet to 13.9 feet, and tremie grouted in place. The surface casing minimizes potential cross contamination between the regolith and bedrock water bearing zones. After the surface casing was installed, the air rotary method was used to drill an 8-inch diameter boring to a total depth of 35.0 feet. A two-inch diameter stainless steel screen with threaded bottom cap was installed from 17.5 feet to 32.8 feet. A 2-inch diameter stainless steel casing was installed from the top of the screen at 17.5 feet and extended 2.4 feet above ground surface. A sandpack was then tremied into the annular space from 16.0 to 32.8 feet, with a 1.9 -foot bentonite pellet seal poured into the annular space above the sandpack from 14.1 to 16.0 feet. The annular space from the top of the bentonite seal to the surface was tremie grouted with a cement/bentonite slurry. A detailed schematic of the well is included on the well installation/completion form.

\subsubsection{We11 Development}

Well number 1149 was developed to remove drill cuttings, silt, and other fines. The monitoring was developed using a Geoguard pump with an air compressor. All pumps were cleanied prior' to use according to specified cleaning procedures (see Paragraph 2.1). The well was developed until a measured total of 221 gallons of water had been evacuated and the clarity of the discharge water was approved by the company representative. The final turbidity value measured at completion was 5.0 NTU's. A development form showing the exact method of development and other pertinent data is appended. 


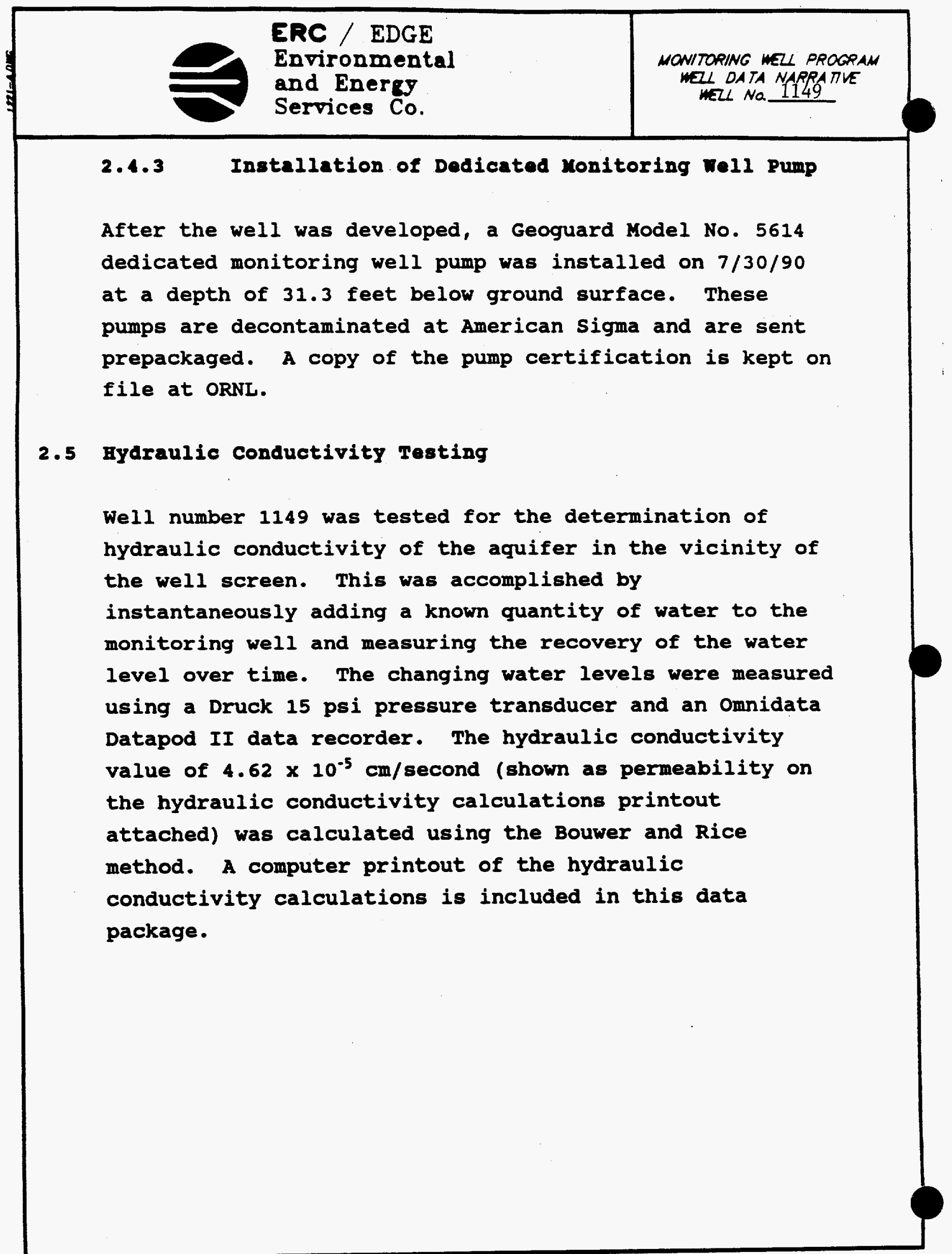




\subsection{Well Location}

Monitoring well number 1246 is located in WAG 11. It is located on the western boundary of White Wing scrap Yard. The location is shown on ORNL drawing number C3E20004A075. Survey coordinates for this well are N $35,090.0576$, E $27,507.5298$ (Y-12 grid) or latitude $35^{\circ}-57^{\prime}-03.51^{\prime \prime}$ and longitude $84^{\circ}-21^{\prime}-05.21^{\prime \prime}$. Coordinate data were provided by Martin Marietta Energy systems. The method used for conversion from Y-12 grid to Tennessee-Lambert state Plane coordinates came from the publication "Tennessee Valley Authority Data Services Branch and Mapping Services Branch, Oak Ridge, Tennessee, DOE Plant Control, November 6, 1985, Field Book: ESS-3115, pp. 1-20." The latitude and longitude were calculated by Adams Craft Herz Walker Engineering, Inc., using methods from the U.S. Coast and Geodetic Survey Publication 62-4, "State Plane coordinates by Automatic Data Processing."

\subsection{Drilling Information}

Well number 1246 was drilled by Geotek Engineering Company. A Ingersoll Rand rig was used to drill this boring for monitor well installation under the operation of Larry Ledbetter with the assistance of Fred Dixon. Drilling commenced on 1-23-90 and was finished on 3-6-90. Paragraph 2.4.1 includes a detailed discussion of the well installation and a well schematic is included on the well installation/ completion form. A synopsis of the drilling activity follows. This information was typed directly from 
field notes and was edited only when necessary for clarification.

1-23-90: The rig was mobilized to the staked location and set up a plastic sheeting. Split spoon samples were taken from surface to refusal at 22.0 feet.

2-2-90: Augered from surface to 6.0 feet using a 22inch auger and set 6.0 feet of $153 / 4$-inch decontaminated steel diverter casing. Grouted diverter casing annulus to surface with 10 sacks cement.

2-9-90: Drill to 18.0 feet using a 14.0-inch air rotary tricone bit.

2-12-90: Drill to 20.0 feet and diverter casing began to leak. Decide to abandon well, skid 10.0 feet and drill new hole. Move to new location, auger to 10.5 feet using a 22-inch augers and set 10.5 feet of 15 3/4-inch decontaminated steel diverter casing.

2-13-90: Grouted diverter casing annulus to surface with 15 sacks cement.

2-16-90: Drill to 20.0 feet using a 14.0-inch air rotary tricone bit.

2-20-90: Drill from 20.0 feet to 40.0 feet using a 14.0-inch air rotary tricone bit. Set 40.0 feet of 10 3/4-inch decontaminated steel surface casing.

2-21-90: Grouted surface casing annulus with 24 sacks cement.

3-6-90: Drilled from 40.0 feet to 85.0 feet using an 8.0-inch air rotary tricone bit. A mud filled cavity was encountered from 66.0 feet to 85.0 feet. The hole would not clean up. 


\begin{tabular}{|c|c|}
\hline & $\begin{array}{l}\text { ERC / EDGE } \\
\text { Environmental } \\
\text { and Energy } \\
\text { Services Co. }\end{array}$ \\
\hline $\begin{array}{l}9-20-90: \\
9-21-90= \\
9-24-90:\end{array}$ & $\begin{array}{l}\text { Decontaminated drill rig, tools, and } 100 \text { feet } \\
\text { of } 8 \text {-inch hollow stem augers. } \\
\text { Mobilized rig to location and set up. Ran in } \\
55 \text { feet of } 8 \text {-inch hollow stem augers. } \\
\text { Ran in } 8 \text {-inch hollow stem augers to } 85.5 \\
\text { feet. Auger refusal at } 85.5 \text { feet. Ran in } 85 \\
\text { feet of Aw drill rods and punched out } \\
\text { stainless steel plug. Ran in } 2 \text {-inch } \\
\text { stainless steel screen and casing. Tremied } \\
\text { in } 12 \text { sacks of sand through hollow stem } \\
\text { augers. } \\
\text { Checked top of sand. Had dropped } 2 \text { feet } \\
\text { overnight so tremied in one more sack of } \\
\text { sand. Grouted annular space with two sacks } \\
\text { of cement. } \\
\text { Finished grouting annular space with } 19 \text { sacks } \\
\text { of cement. }\end{array}$ \\
\hline
\end{tabular}

This well was logged by ERC Environmental and Energy Services Co., Inc., hydrogeologists Bruce McMaster, Timothy A. Lee and Michael L. Ebers. All well construction materials and supplies were from Martin Marietta Energy Systems approved batches. The batch origin of individual items is shown on the included Monitoring Well Materials Certification form.

\subsection{Tochnical Information}

\subsection{Decontamination Procedures}

The drilling rig, down hole tools, surface casing, stainless steel screen, stainless steel casing, centralizers, and stainless steel silt trap underwent the cleaning decontamination procedures outlined in the 


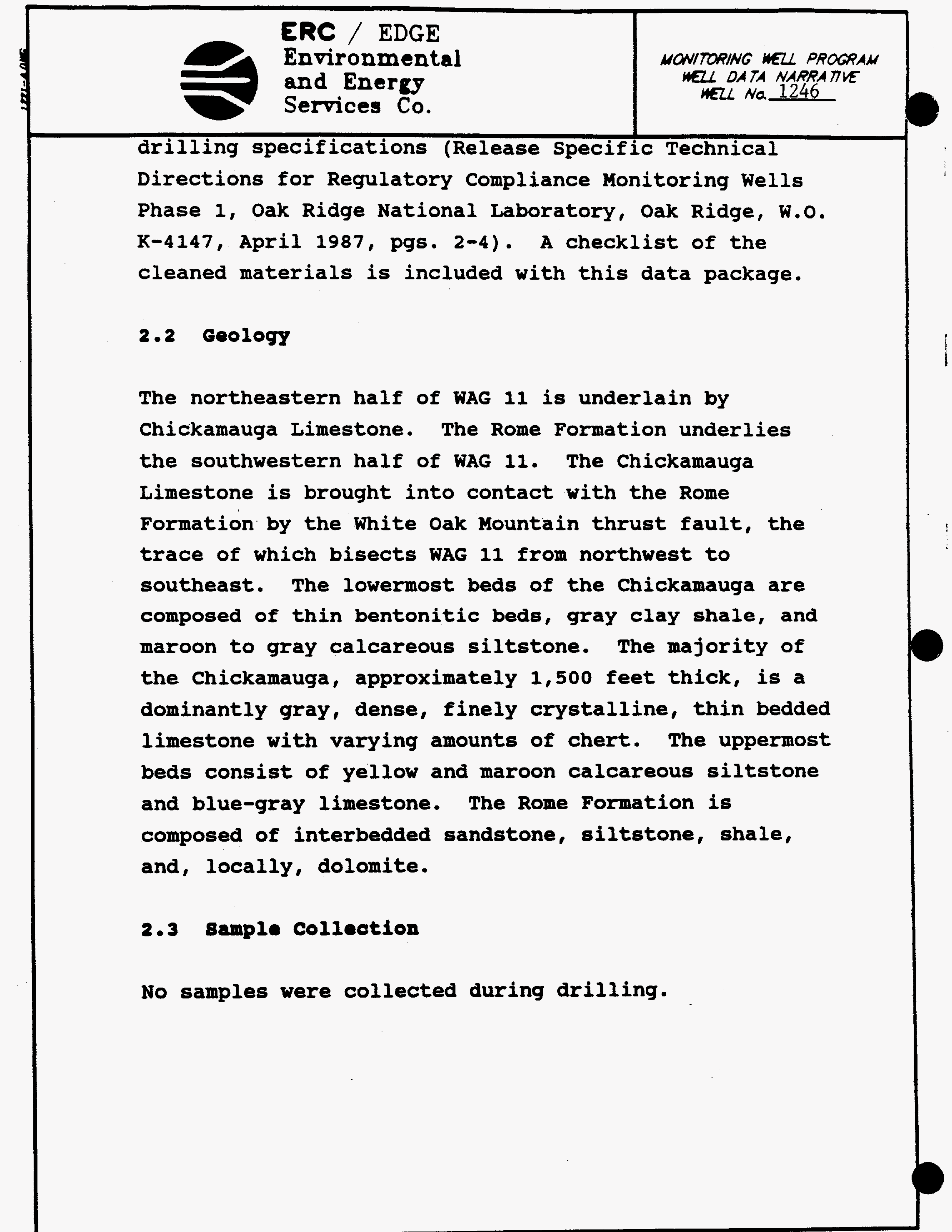




\subsection{Installation and Development}

\subsubsection{Installation}

This was a Type B well. A 22.0-inch diameter boring was augered from ground surface to 6.0 feet. A 15 3/4inch diverter casing was installed from surface to 6.0 feet below ground surface and grouted in place. The boring was drilled with a 14.0 -inch air rotary tricone roller bit from 6.0 feet to 40.0 feet and tremiegrouted in place. The surface casing minimizes potential cross contamination between the regolith and bedrock water bearing zones. After the surface casing was installed, the air rotary method was used to drill an 8-inch diameter boring to a total depth of 86.63 feet. A 2-inch diameter stainless steel silt trap was installed from 71.4 feet to 86.63 feet. A 2inch diameter stainless steel screen was installed from 56.4 feet to 71.4 feet. A 2-inch diameter stainless steel casing was installed from the top of the screen at 56.4 feet and extended 2.05 feet above ground surface. A sandpack was then tremied into the annular space from 86.63 up to 53.0 feet, with a 2.6 foot bentonite pellet seal poured into the annular space above the sandpack from 50.4 to 53.0 feet. The annular space from the top of the bentonite seal to the surface was tremie grouted with a cement/bentonite slurry. A detailed schematic of the well is included on the well installation/completion form.

\section{4 .2 We11 Development}

Well number 1246 was developed to remove drill cuttings, silt, and other fines. The monitoring was 


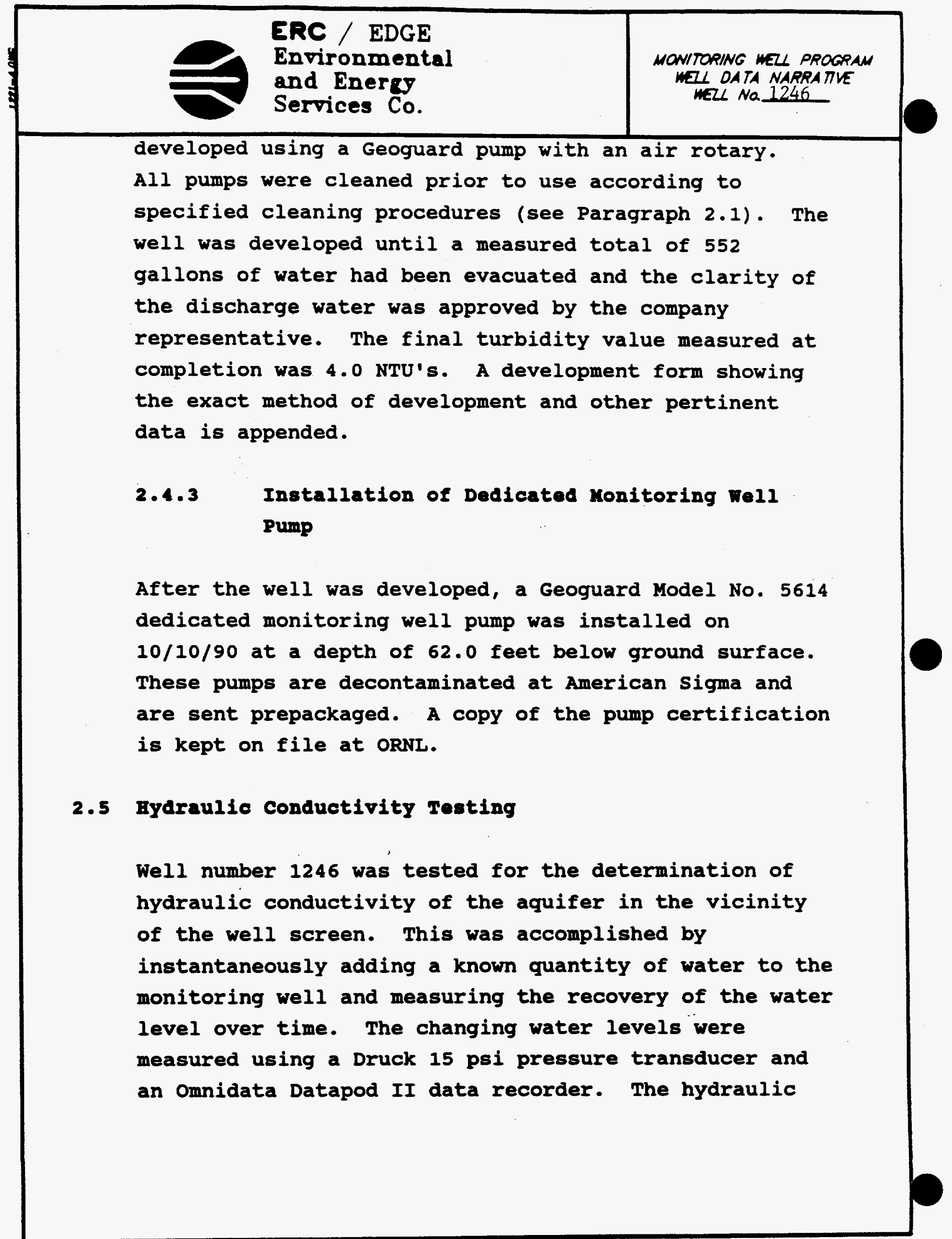


ERE / EDGE

Environmental

and Energy

Services Co.

MONITORING WELL PROGRAM

WEI DATA NARRATE

MELL Na 1246

conductivity value of $4.89 \times 10^{-4} \mathrm{~cm} / \mathrm{second}$ (shown as permeability on the hydraulic conductivity calculations printout attached) was calculated using the Bower and Rice method. A computer printout of the hydraulic conductivity calculations is included in this data package.

PACE 7 of 21 
ERC / EDGE

Environmental

and Energy

Services Co.
MONITORING WELL PROGRAM

WELL DATA NARRATVE

WELL NO. 1139

\subsection{General Information}

\subsection{Well Location}

Monitoring well number 1139 is located in WAG 11. It is located in the southern boundary of "White Wing scrap Yard" or WAG 11. The location is shown on ORNL drawing number C3E20004A075. Survey coordinates for this well are $\mathrm{N} 34,507.9669, \mathrm{E} 28,700.6980$ (X-10 grid) or latitude $35^{\circ}-57^{\prime}-05.50^{\prime \prime}$ and longitude $84^{\circ}-20^{\prime}-48.93^{\prime \prime}$. Coordinate data were provided by Martin Marietta Energy systems. The method used for conversion from $x-10$ grid to Tennessee-Lambert state Plane coordinates came from the publication "Tennessee Valley Authority Data Services Branch and Mapping Services Branch, Oak Ridge, Tennessee, DOE Plant Control, November 6, 1985, Field Book: ESS-3115, pp. 1-20." The latitude and longitude were calculated by Adams Craft Herz Walker Engineering, Inc., using methods from the U.S. Coast and Geodetic survey Publication 62-4, "State Plane coordinates by Automatic Data Processing."

\subsection{Drilling Information}

Well number 1139 was drilled by Geotek Engineering Company. An Ingersoll Rand T-4 rig was used to drill this boring for monitor well installation under operation of Larry Ledbetter with the assistance of Fred Dixon. Drilling commenced on 1-19-90 and was finished on 1-22-90. Paragraph 2.4.1 includes a detailed discussion of the well installation and a well schematic is included on the well installation/ completion form. A synopsis of 
the drilling activity follows. This information was typed directly from field notes and was edited only when necessary for clarification.

1-19-90 The rig was mobilized to the staked location and set up on plastic sheeting. Split spoon samples were taken from surface to refusal at 7.5 feet. The boring was deepened with a 6-inch auger to 22.5 feet.

1-22-90 The boring was deepened from 22.5 feet to auger refusal at 33.5 feet with a 6 -inch auger. Two inch stainless steel screen and casing was then set with sand pack and bentonite pellet seal.

1-23-90 The annulus was grouted to surface with 1 sack cement.

This well was logged by ERC Environmental and Energy Services Co., Inc., hydrogeologist Timothy A. Lee. All well construction materials and supplies were from Martin Marietta Energy Systems approved batches. The batch origin of individual items is shown on the included Monitoring Well Materials Certification form.

\subsection{Technical Information}

\subsection{Decontamination Procedures}

The drilling rig, down hole tools, surface casing, stainless steel screen, stainless steel casing, centralizers, and stainless steel silt trap underwent the cleaning decontamination procedures outlined in the drilling specifications (Release Specific Technical Directions for Regulatory Compliance Monitoring Wells Phase 1, Oak Ridge National Laboratory, Oak Ridge, W.O., 
K-4147, April 1987, pgs, 2-4). A checklist of the cleaned materials is included with this data package.

\subsection{Geology}

The northeastern half of WAG 11 is underlain by Chickamauga Limestone. The Rome Formation underlies the southwestern half of WAG 11. The Chickamauga Limestone is brought into contact with the Rome Formation by the White Oak Mountain thrust fault, the trace of which bisects WAG 11 from northwest to southeast. The lowermost beds of the Chickamauga are composed of thin bentonitic beds, gray clay shale, and maroon to gray calcareous siltstone. The majority of the chickamauga, approximately 1,500' thick, is a dominantly gray, dense, finely crystalline, thin bedded limestone with varying amounts of chert. The uppermost beds consist of yellow and maroon calcareous siltstone and blue-gray limestone. The Rome Formation is composed of interbedded sandstone, siltstone, shale and locally, dolomite.

\subsection{Sample Collection}

One soil sample was collected during drilling, placed in an I-CHEM specialty cleaned glass container, sealed and submitted to Sample Receiving, Analytical Chemistry Division, Bldg. 4500s, ORNL. A chain of custody form for this sample is included with this data package. Soil sample 1139s01 was collected in the split spoon interval from $6.2^{\prime}$ to $6.5^{\prime}$ on 1-19-90.

A bulk density soil sample was collected from the split spoon sample interval from 1.0' to. $1.3^{\prime}$. The sample was 
measured, weighed and a bulk density of $2.22 \mathrm{grams} / \mathrm{cm}^{3}$ was calculated.

\subsection{Installation and Development}

\subsubsection{Installation}

This was a Type A well. A 6-inch diameter boring was split spooned and augered from ground surface to a total depth of 33.5 feet. A 2-inch diameter stainless steel screen with threaded bottom cap was installed from 7.8 feet to 33.0 feet. A 2-inch diameter stainless steel casing was installed above the screen from 7.8 feet to 2.2 feet above ground surface. A sandpack was then tremied into the annular space from 4.4 to 33.9 feet, with a 1.6 foot bentonite pellet seal poured into the annular space above the sandpack from 2.8 to 4.4 feet. The annular space from the top of the bentonite seal to the surface was tremie grouted with a cement/bentonite slurry. A detailed schematic of the well is included on the well installation/completion form.

\subsubsection{Well Development}

Well number 1139 was developed to remove drill cuttings, silt, and other fines. The monitoring was developed using a Geoguard pump with an air compressor. All pumps were cleaned prior to use according to specified cleaning procedures (see Paragraph 2.1). The well was developed until a measured total of 565 gallons of water had been evacuated and the clarity of the discharge water was approved by the company representative. The final 
turbidity value measured at completion was $>100$ NTU's. A development form showing the exact method of development and other pertinent data is appended.

\subsubsection{Installation of Dedicated Monitoring Well Pump}

After the well was developed, a Geoguard Model No. 5614 dedicated monitoring well pump was installed on $7 / 31 / 90$ at a depth of 29.8 feet below ground surface. These pumps are decontaminated at American sigma and are sent prepackaged. A copy of the pump certification is kept on file at ORNL.

\subsection{Hydraulic Conductivity Testing}

Well number 1139 was tested for the determination of hydraulic conductivity of the aquifer in the vicinity of the well screen. This was accomplished by instantaneously adding a known quantity of water to the monitoring well and measuring the recovery of the water level over time. The changing water levels were measured using a Druck 15 psi pressure transducer and an omnidata Datapod II data recorder. The hydraulic conductivity value of $2.71 \times 10^{-3} \mathrm{~cm} / \mathrm{second}$ (shown as permeability on the hydraulic conductivity calculations printout attached) was calculated using the Bouwer and Rice method. A computer printout of the hydraulic conductivity calculations is included in this data package. 


\section{PRE-DRILLING CHECKLIST FOR MONITORING WELLS}

\section{PRE-DRILUNG TASKS}

1. EXCAVTION PERMIT OBTAINED

2. ALL EQUIPMENT HAS BEEN CLEANED BEFORE DRILLING.

30. SCREEN AND CASING HAVE BEEN WASHED, STEAMED, RINSED WIH DE-IONIZED OR DISTILLED WATER, RINSED WTH ISOPROPV ALCOHOL, WRAPPED WTH PROTECTVE COVERING AND STORED OFF THE GROUND.

36. PRE-PACKAGED SCREENS, CASING AND CENTRALIZERS WERE USED.

4. WORK AREA FOR SAMPLE EXAMINATION COVERED WTH CLEAN POL VETHRENE.

5. CLEAN KNIVES, GLOVES, SAMPLE JARS AND LABELS ON HAND.

6. POL YETHRENE COVER IN PLACE OVER HOLE.

7. AIR ROTARY COMPRESSED AIR SAMPLED.
COMPLIANCE

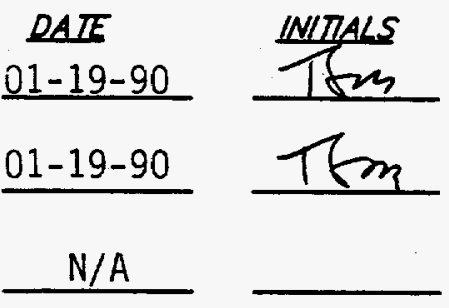

$\underline{01-22-90}$

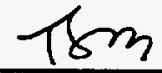

$01-22-90$

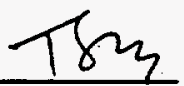

01-19-90

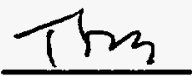

$01-22-90$

RESULTS:

ADOITONAL NOTES/OBSERVATIONS: 


\section{DECONTAMINATION CHECKLIST DRILLING EQUIPMENT}

\begin{tabular}{|c|c|c|c|c|c|}
\hline EQUIPMENT & SCRAPE & $\begin{array}{l}\text { STEAN } \\
\text { CLEAN }\end{array}$ & $\begin{array}{l}\text { STEAM } \\
\text { RINSE }\end{array}$ & $\begin{array}{c}\text { ISOPROPYL } \\
\text { ALCOHOL } \\
\text { RINSE }\end{array}$ & $\begin{array}{c}\text { DEIONIZED } \\
\text { WATER } \\
\text { RINSE }\end{array}$ \\
\hline$R / G$ & $x$ & $x$ & $x$ & $N / A$ & $N / A$ \\
\hline AUGERS & $x$ & $x$ & $x$ & $x$ & $x$ \\
\hline BITS & $x$ & $x$ & $x$ & $x$ & $x$ \\
\hline RODS & $\dot{x}$ & $x$ & $x$ & $x$ & $x$ \\
\hline SAMPLERS & $x$ & $x$ & $x$ & $x$ & $x$ \\
\hline PIPES & $x$ & $x$ & $x$ & $x$ & $x$ \\
\hline WORK TOOLS & $x$ & $x$ & $x$ & $x$ & $x$ \\
\hline AUGER PINS & $x$ & $x$ & $x$ & $x$ & $x$ \\
\hline BAILER & $x$ & $x$ & $x$ & $x$ & $x$ \\
\hline & & & & & \\
\hline & & & & & \\
\hline & & & & & \\
\hline
\end{tabular}

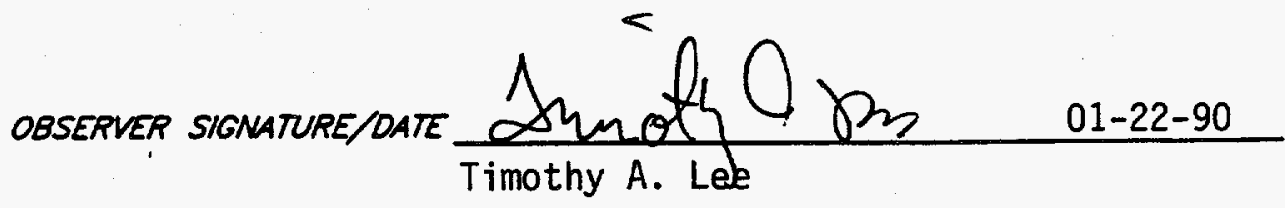




\section{ERC / EDGE Environmental \\ and Energy \\ Services Co.}

\begin{tabular}{l} 
ORNL NONITORING WELL LOG \\
\hline LOCA MON: WAG 11 \\
ORILLER: Larry Ledbetter \\
HELPER: Fred Dixon \\
ORILL: Ingersol Rand I-4
\end{tabular}

TPRE ORILUNG: SP] it Spoon. Auger

No. SAMPLES TAKEN: One

CONTAINUENT TPE: Plastic pan

THCXNESS OF SOL (RERUSNL DEPTH): 33.5

DEPDH DRILEO IN ROCX: 0.0

TOTAL OEPTH OF WELL: 33.5

\begin{tabular}{|c|c|c|c|c|}
\hline \multicolumn{2}{|c|}{ 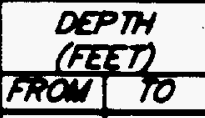 } & $\begin{array}{l}\text { SAMPLE } \\
\text { (NUMBER } \\
\text { NTIERVAL) }\end{array}$ & $\begin{array}{c}\text { PEECENT } \\
\text { RECONERY } \\
\text { (SPUT SPOONS) }\end{array}$ & sak/Beprock acscerption \\
\hline 0.0 & 1.0 & & augered & Gravel fill \\
\hline 1.0 & 2.7 & & 100 & Clay, mottled, moderate vellowish brown and \\
\hline & & & & dark vellowish orange, drv. black streaks and \\
\hline & & & & iron stains. \\
\hline 2.7 & 3.0 & & 100 & Clay mottled, dark yellowish orange and light \\
\hline & & & & olive gray, dry, iron stains. \\
\hline 3.0 & 3.6 & & 65 & Clay, mottled, light olive gray, and dark \\
\hline & & & & yellowish orange, dry, iron stains. \\
\hline 3.6 & 5.0 & & 65 & Clay, gravish olive green, dry, plastic, \\
\hline & & & & scattered fragments of green (alauconite?) \\
\hline & & & & and dark yellowish orange sandstone. \\
\hline 3.0 & 5.5 & & 100 & Clay, light olive gray, damp, and shale, \\
\hline & & & & grayish blue green, iron stains. \\
\hline 5.5 & 6.7 & 1139501 & 100 & Clav, mottled, light olive gray and dark \\
\hline & & from 6.2 to 6. & 5 & yellowish orange, wet, very wet from $6.0^{\prime}$ to \\
\hline & & & & $6.3^{\prime}$, iron stains. \\
\hline 6.7 & 7.0 & & 100 & Shale, dark yellowish orange, iron \\
\hline & & & & stains. \\
\hline 7.0 & 7.5 & & 100 & Shale, dark yellowish orange. \\
\hline & 7.5 & & & Split Spoon refusal. \\
\hline 7.5 & 33.5 & & Augered & Shale with harder sandstone lenses. \\
\hline
\end{tabular}

DREUNG RZUD SAMPLES:

TrPE: N/A DATE: N/A

\section{DATE: START: $01-19-90$ \\ FN/SH: $\quad 01-22-90$ \\ LOGGED BY. Timothy A. Lee}

HEAL TH PHYSICST: Carl Stooksbarry

LUBRYCWT MPE: Green Stuff

TPE: Soil 
WELL INSTALLATION/COMPLETON FORM

LOGGED

BY:

O.R.N.L. MONITORING WELL PROGRAM

PROOFED

BY: Michael L. Ebers

ORILUNG COMPAY: Geotek

ORILER: Larry Ledbetter HEZPER: Fred Dixon

EQUIPMENT

$\mathbf{a}$

口

MATERUKS USED

EST. USED

va. va.

25.0 FEET of ? 2 N. S.S. SCREEN

10.0 FEET of 2 N. S.S. CASNG

4.18 .0 sacks of swo

25.025 .0 POCNOS OF BENTONIE PELLETS

0.41 .0 SACKS OF CEMENT

5.0 POUNOS OF POWOERED BENTONTE

8.0 GNLONS OF MATER (CENENTING)

REASON FOR ONTLAEINCES BETILEEN ESTIMATED nolumes wo used vacumes

Fractures and irregular boring

diameters.

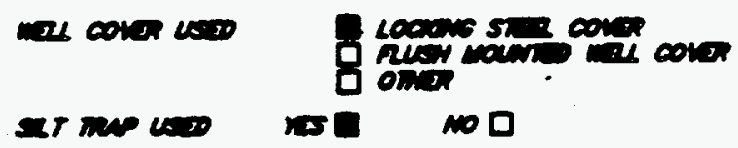

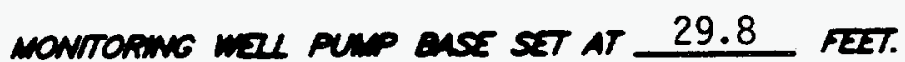

CENTRULERS AT $\frac{7.0}{31.0}$ FETT.

Fב2.

FEET.

NOTE:

NI DEPTAS APE MEASUAED

FROW GROUND SURFACE

UNEESS OTHERWASE NOTED.

TYPE A WELL
LOCATION WAG 11

OANL GRO COOROINATES

$N 34,507.9669$

E 28.700 .6980

ELEV. GROUND 814.31

ELEV. TOP STANLESS

STEEL CASING 816.02

DRILLING DATES:

STARTED: 01-19-90

FNISHED $01-22-90$

LOCONG STER COVER

8 NOH DAMETER

STER POTECNVE CASNG

3.16-T. woove ano

To 2.0 Tr. szow

anano sensace

Conarese PAO

onour sen

2.8 rET

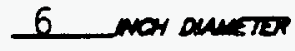

sonstace

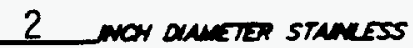

ster asove 1.71 T. woole

arouno suosace to 7.8 .

ezow enowo sensace

contrueser (mp)

ONTOWTE PZLT SEN

$2.8 \pi 4.4$ rex

sus per

4.4 T3 33.0 काया

2 mos anciss

stavess stez 0.010

sorid sonsor

Z.8 $\pi 32.8$ लाख

2 now antios staness

sisz ser mappon

$32.8 \pi 33$ مـ

corrow of canorece

NOT TO SCNE 


\section{MONITORING WELL MATERIALS CERTIFICA TION}

\begin{tabular}{|c|c|c|c|}
\hline$I T E M / M A T E R I A L$ & & DATE USED & BATCH NUMBER \\
\hline \multicolumn{2}{|l|}{ SANO } & $01-22-90$ & 2 \\
\hline \multirow{2}{*}{ BENTONITE } & Pellets & $01-22-90$ & 1 \\
\hline & Powder & $01-23-90$ & 4 \\
\hline STAINLESS STEEL SCREEN & (PREPACKAGED $\quad$ NES & $01-22-90$ & 3 \\
\hline STAINLESS STEEL CASING & $\left(\begin{array}{lll}\text { (PREPACKAGED } & \text { VES } \\
\text { NO }\end{array}\right)$ & $01-22-90$ & 3 \\
\hline STAINLESS STEEL CENTRALIZERS & $\left(\begin{array}{ll}\text { (PREPACKAGED } & \text { YES } \\
\text { NO }\end{array}\right)$ & $01-22-90$ & 2 \\
\hline STAINLESS STEEL CAPS & $\left(\begin{array}{lll}\text { PREPACKAGED } & \text { YES } \\
\text { NO }\end{array}\right)$ & $01-22-90$ & 2 \\
\hline MONITORING WELL PUMP & $\left(\begin{array}{ll}\text { (PREPACKAGED } & \text { YES } \\
\text { NO }\end{array}\right)$ & $\frac{07-31-90}{01-23-90}$ & $\frac{8}{5}$ \\
\hline \multicolumn{2}{|l|}{ GROUT } & & \\
\hline \multicolumn{2}{|l|}{ WELL COVERS } & & \\
\hline SURFACE CASING & & $N / A$ & $N / A$ \\
\hline
\end{tabular}

COMMENTS:

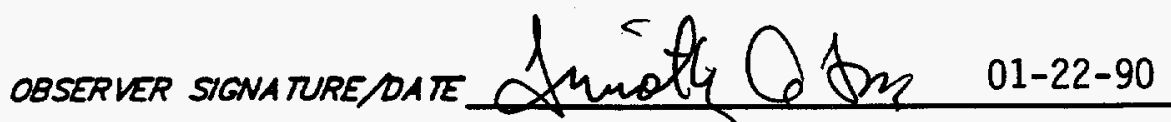

Timothy A. Lee 


\section{POST-WELL COMPLETON \\ CHECKLIST}

\section{POST-WEL COMELETION TASKS}

COMPLIANCE

1. WU SCRAPED FRON AUGERS SAMPLERS ANO MLL

DA.T

IAITALS

OTHER EQUIPMENT.

01-22-90 Th2

2. ALL WUD RROW RIG AND EQUPIENT SCRAPINGS ANO CUTINOS DISPOSED OF IN ACCORDANCE WTH THE SPECIFCA IION" PROMOED.

3 WZL DEVEZOFEO IN ACCOROANCE WIH THE SPECATCA TON PROVDED ANO DETAKS OF THE OEVEZOPWENT ACHUTY RECOPOED.

4. DRKLNG STE PROPERLY QLEANED UP AFTER COMPLETION OF MZL INSTALLANON.

01-22-90 Tos

$07-31-90$

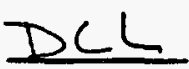

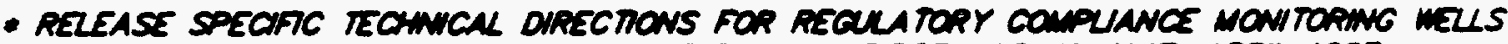

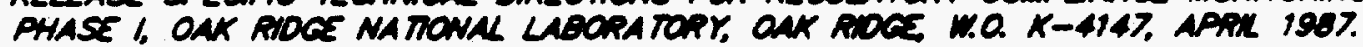

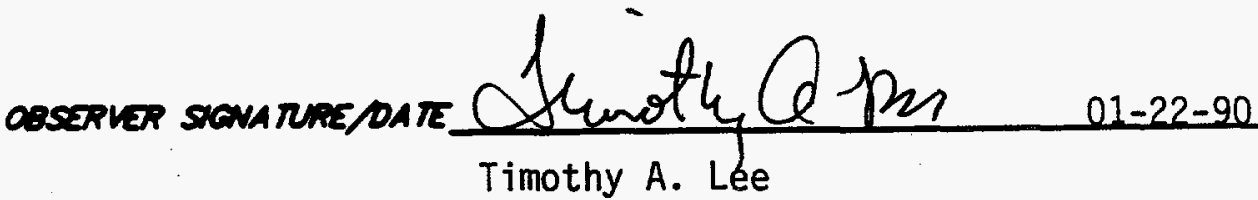

Timothy A. Lee

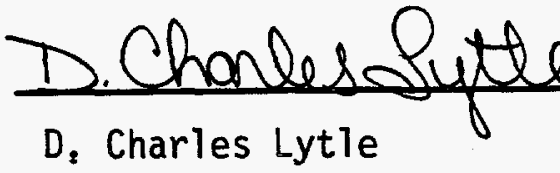

$07-31-90$ 


\section{MONITORING WELL \\ DEVELOPMENT FORM}

DEVELOPMENT DETAILS

METHOD OF

DEVELOPMENT: Surging and Pumping

DEVELOPMENT

BEGAN DATE: $\quad 07-30-90$ TME:

DEVELOPMENT

ENDING DATE:

$07-31-90$

DEVELOPMENT

OBSERVED BY:

D. Charles Lytle

ONE WELL VOLUME: 16.5 GALLONS

TOTAL GALLONS PUMPED: 565 TOTAL WELL VOLUMES PUMPED: 34.2

INITAL PH: 8.8 FNAL PH: 8.8

INITAL CONOUCTUTY (KS/cm): 502 FINAL CONDUCHUTY (HS/cm): 550

DESCRIPTION OF INITAL TURBIDITY: MUddY

OESCRIPTION OF FNAL TURBIDITY: MUddV

FINAL MEASURED TURBIDITY: > 100NTU'S

WELL APPROVED BY: R.C. WIIlliams MMES.

OOOR

QE WATER. None

WATER

OISCHARGED

GROUND SURFACE

口 TANK TRUCK

To:

口 STORM SEWERS

ㅁ STORACE TANKS

口 DRUMS

D OTHER

INITAL PRE-DEVELOPMENT

WATER DEPTH: 5.1 feet from ground surface.

DEVELOPMENT OBSERVATIONS

ogserver sugnature pate D. Charlesalutlle7-31-90 D. Charles Lyt le 


\begin{tabular}{|c|c|c|c|c|c|c|c|c|c|}
\hline 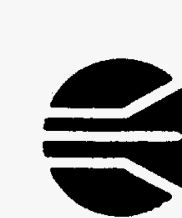 & $\begin{array}{l}\text { ER } \\
\text { En } \\
\text { and } \\
\text { Ser }\end{array}$ & $\begin{array}{l}\text { onme } \\
\text { onmergs } \\
\text { in Ces }\end{array}$ & & & & & & $\begin{array}{l}\text { MEL } \\
\angle O C \\
D A\end{array}$ & $\begin{array}{l}\text { vo. } \frac{1139}{\text { ON: WAG } 11} \\
07-30-90 \\
\end{array}$ \\
\hline & $M O$ & TORII & $W E L L$ & $D E V E$ & $\mathrm{LOF}$ & $M E N$ & $P R C$ & $F R E S$ & \\
\hline & & & & & & ONE & WELL VO & $V E=$ & .5 GALLONS \\
\hline$D A T E$ & TME & $\begin{array}{l}\text { QNeONS } \\
\text { PUNPED }\end{array}$ & 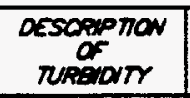 & $\begin{array}{l}\text { NEASUAEDD } \\
\text { RRELONTH } \\
\text { (NUUS) }\end{array}$ & $\rho H$ & 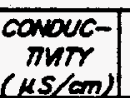 & $\begin{array}{l}\text { TOTAK } \\
\text { Gllows } \\
\text { PUMPED }\end{array}$ & $\begin{array}{l}\text { met } \\
\text { volumes } \\
\text { puinezo }\end{array}$ & COMMENTS \\
\hline $07-30-90$ & 1200 & 300 & Muddy & $\ldots$ & 8.8 & 502 & 300 & 18.2 & \\
\hline $07-30-90$ & 1300 & 45 & Muddy & --- & 8.8 & 550 & 345 & 21.0 & \\
\hline $07-31-90$ & 1400 & 220 & Muddy & *_-- & 8.8 & $=-$ & 565 & 34.2 & $\begin{array}{l}\text { Horiba is } \\
\text { in for }\end{array}$ \\
\hline & & & & & & & & & repairs \\
\hline & & & & & & & & & \\
\hline & & & & & & & & & \\
\hline & & & & & & & & & \\
\hline & & & & & & & & & \\
\hline & & & & & & & & & \\
\hline & & & & & & & & & \\
\hline & & & & & & & & & \\
\hline & & & & & & & & & \\
\hline & & & & & & & & & \\
\hline & & & & & & & & & \\
\hline & & & & & & & & & \\
\hline & & & & & & & & & \\
\hline & & & & & & & & & \\
\hline $\begin{array}{l}\text { RESUL TS } \\
\text { OF DEVEL }\end{array}$ & $\begin{array}{l}\text { IT END } \\
\text { PMENT }\end{array}$ & & Muddy & $\star_{-}--$ & 8.8 & & 565 & 34.2 & \\
\hline
\end{tabular}

COMMENTS Excellent recharger and producer. Passed with 34.2 wel1 volumes. Water remains muddy. Moved to another hole.

* Greater than 100 NTU's.

OBSERVER SIGNATURE DATE D. Chonles S yle07-31-90 


\section{HYDRAULIC CONDUCTIVTY CALCULATIONS}

$\begin{array}{rrr}\text { (SEC TIME }^{\text {TI }} & \begin{array}{r}\text { DEPTH TO WATER } \\ \text { (FEET) }\end{array} & \begin{array}{r}\text { HEAD } \\ \text { (FEET) }\end{array} \\ 2.00 & & \\ 4.00 & 4.040 & 3.040 \\ 6.00 & 3.970 & 2.970 \\ 8.00 & 3.550 & 2.550 \\ 10.00 & 2.740 & 1.740 \\ 12.00 & 2.180 & 1.180 \\ 14.00 & 1.760 & .760 \\ 16.00 & 1.500 & .500 \\ 18.00 & 1.360 & .360 \\ 20.00 & 1.250 & .250 \\ 22.00 & 1.180 & .180 \\ 24.00 & 1.120 & .120 \\ 26.00 & 1.070 & .070 \\ & 1.020 & .020\end{array}$

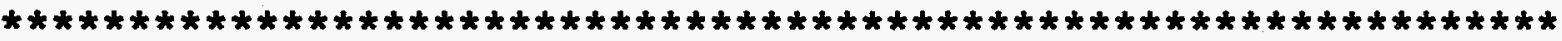

METHOD OF BOUWER AND RICE

COMPUTED RESULTS USING DIAMETER OF DRILLED HOLE:

PERMEABILITY $=8.91 \mathrm{E}-05 \mathrm{FT} / \mathrm{SEC} \quad=2.71 \mathrm{E}-03 \mathrm{CM} / \mathrm{SEC}$

TRANSMISSIVITY $=2.23 \mathrm{E}-03 \mathrm{FT} * 2 / \mathrm{SEC}$

COMPUTED RESULTS USING DIAMETER OF CASING AND SCREEN:

PERMEABILITY $=1.12 \mathrm{E}-04 \mathrm{FT} / \mathrm{SEC}=3.42 \mathrm{E}-03 \mathrm{CM} / \mathrm{SEC}$

TRANSMISSIVITY $=2.80 \mathrm{E}-03 \mathrm{FT} * 2 / \mathrm{SEC}$ 


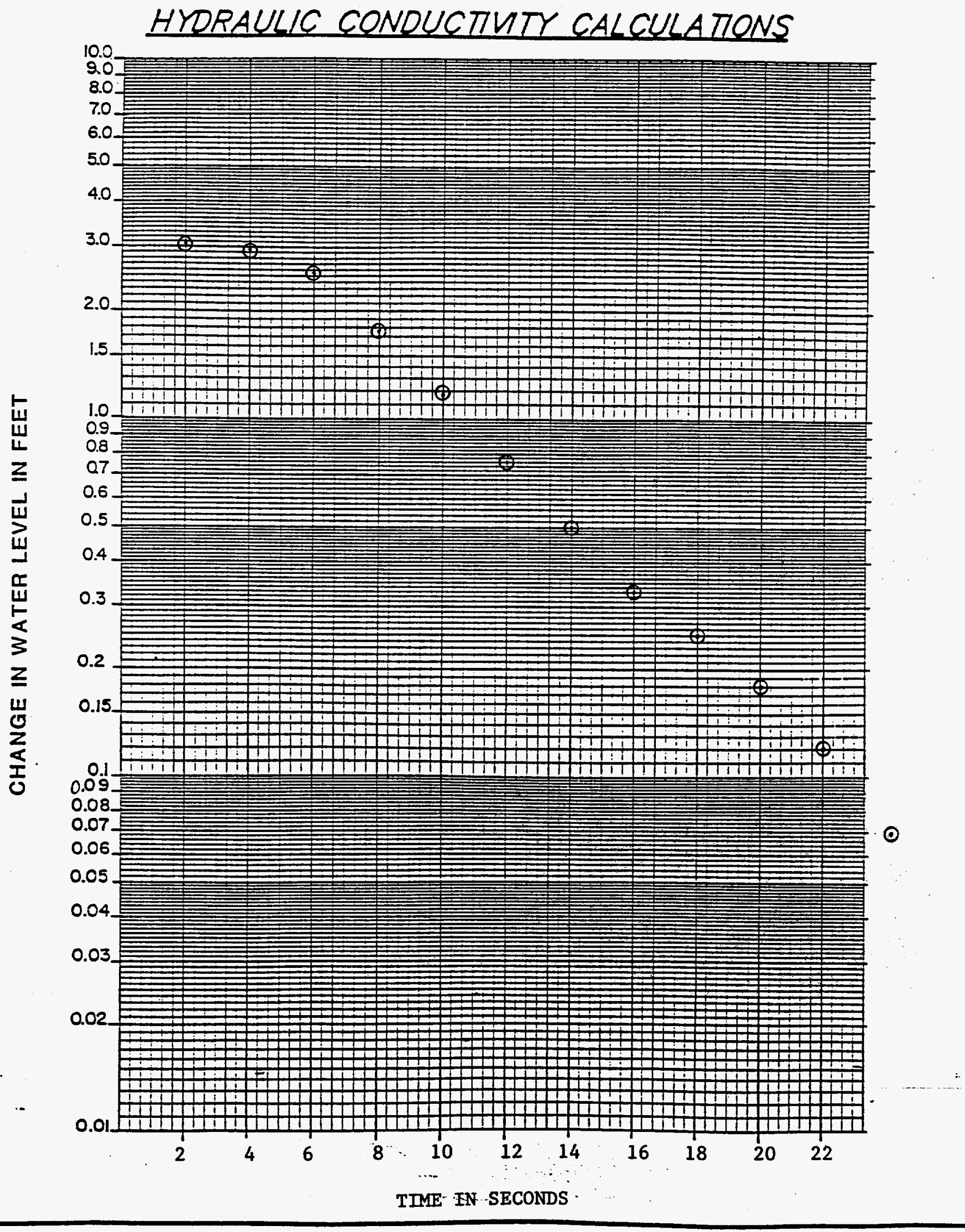


ERC / EDGE

Environmental

and Energy

Services Co.

\subsection{General Information}

\subsection{Well Location}

Monitoring well number 1140 is located in WAG 11. It is located in the southern boundary of "White Wing Scrap Yard" or WAG 11. The location is shown on ORNL drawing number C3E20004A075. Survey coordinates for this well are $\mathrm{N} 34,497.9754, \mathrm{E} 28,111.2064$ (X-10 grid) or latitude $35^{\circ}-57^{\prime}-02.17^{\prime \prime}$ and longitude $84^{\circ}-20^{\prime}-54.82^{\prime \prime}$. Coordinate data were provided by Martin Marietta Energy systems. The method used for conversion from $x-10$ grid to Tennessee-Lambert State Plane coordinates came from the publication "Tennessee Valley Authority Data Services Branch and Mapping Services Branch, Oak Ridge, Tennessee, DOE Plant Control, November 6, 1985, Field Book: ESS-3115, pp. 1-20." The latitude and longitude were calculated by Adams Craft Herz Walker Engineering, Inc., using methods from the U.S. Coast and Geodetic survey Publication 62-4, "State Plane Coordinates by Automatic Data Processing."

\subsection{Drilling Information}

Well number 1140 was drilled by Geotek Engineering Company. An Ingersoll Rand T-4 rig was used to drill this boring for monitor well installation under operation of Larry Ledbetter with the assistance of Fred Dixon. Drilling commenced on 1-31-90 and was finished on 3-5-90. Paragraph 2.4.1 includes a detailed discussion of the well installation and a well schematic is included on the well installation/completion form. A synopsis of the 


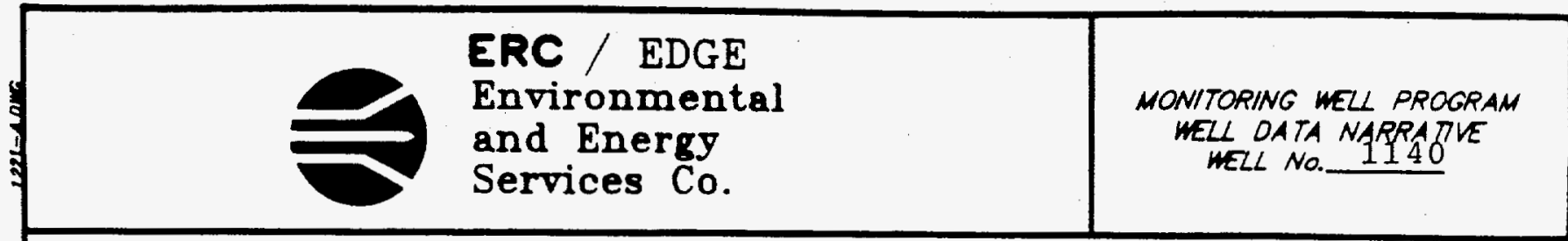

drilling activity follows. This information was typed directly from field notes and was edited only when necessary for clarification.

1-19-90 The rig was mobilized to the staked location and set up on plastic sheeting. The boring was augered to 6.0 feet with a 14-inch auger. Set 6.0 feet of $103 / 4$-inch decontaminated steel diverter casing and grouted it into place. Moved rig from location.

3-2-90 The rig was moved to location. Drilled to 62.5 feet using an $8.0-$ inch air rotary tricone bit.

3-5-90 Set 2-inch stainless steel screen and casing with sandpack and bentonite pellet seal. Move rig from location.

3-6-90 Grouted annulus with 7.0 sacks cement.

This well was logged by ERC Environmental and Energy Services Co., Inc., hydrogeologist Timothy A. Lee. All well construction materials and supplies were from Martin Marietta Energy systems approved batches. The batch origin of individual items is shown on the included Monitoring Well Materials certification form.

\subsection{Technical Information}

\subsection{Decontamination Procedures}

The drilling rig, down hole tools, surface casing, stainless steel screen, stainless steel casing, centralizers, and stainless steel silt trap underwent the 
cleaning decontamination procedures outlined in the drilling specifications (Release Specific Technical Directions for Regulatory Compliance Monitoring Wells Phase 1, Oak Ridge National Laboratory, Oak Ridge, w.0., K-4147, April 1987, pgs, 2-4). A checklist of the cleaned materials is included with this data package.

\subsection{Geology}

The northeastern half of WAG 11 is underlain by Chickamauga Limestone. The Rome Formation underlies the southwestern half of WAG 11. The Chickamauga limestone is brought into contact with the Rome Formation by the White oak Mountain thrust fault, the trace of which bisects WAG 11 from northwest to southeast. The lowermost beds of the Chickamauga are composed of thin bentonitic beds, gray clay shale, and maroon to gray calcareous siltstone. The majority of the Chickamauga, approximately 1,500' thick, is a dominantly gray, dense, finely crystalline, thin bedded limestone with varying amounts of chert. The uppermost beds consist of yellow and maroon calcareous siltstone and blue-gray limestone. The Rome Formation is composed of interbedded sandstone, siltstone, shale and locally, dolomite.

\section{3 sample collection}

No samples were collected during drilling.

A bulk density soil sample was collected from the split spoon sample interval from 3.5 ' to 3.8 '. The sample was measured, weighed and a bulk density of $2.22 \mathrm{grams} / \mathrm{cm}^{3}$ was calculated. 
The Ingersoll Rand T-4 compressed air was sampled with a cloth filter inserted between drill rods on $3 / 2 / 90$. The sample was examined with an ultraviolet light for the presence of hydrocarbons. The filter showed no detectable signs of hydrocarbons.

\subsection{Installation and Development}

\subsubsection{Installation}

This was a Type D well. A 14.0-inch diameter boring was augered from ground surface to 6.0 feet and a 10 3/4-inch diverter casing was installed and grouted. An 8-inch diameter boring was then drilled with an air rotary tricone roller bit from 6.0 to 62.5 feet. A 2-inch diameter stainless steel screen with threaded bottom cap was installed from 32.3 to 62.5 feet. A 2-inch diameter stainless steel casing was installed above the screen at 32.3 feet and extended 2.8 feet above ground surface. A sandpack was then tremied into the annular space from 30.5 to 62.5 feet, with a 1.5 foot bentonite pellet seal poured into the annular space above the sandpack from 29.0 to 30.5 feet. The annular space from the top of the bentonite seal to the surface was tremie-grouted with a cement/bentonite slurry. A detail of the well is included on the well installation/completion form.

\subsubsection{Well Development}

Well number 1140 was developed to remove drill cuttings, silt, and other fines. The monitoring was developed using a Geoguard pump with an air compressor. All pumps were cleaned prior to use according to specified cleaning procedures (see Paragraph 2.1). The well was developed 
ERC / EDGE

Environmental

and Energy

Services Co.

until a measured total of 120 gallons of water had been evacuated and the clarity of the discharge water was approved by the company representative. The final turbidity value measured at completion was 4.0 NTU's. A development form showing the exact method of development and other pertinent data is appended.

\subsubsection{Installation of Dedicated Monitoring Well Pump}

After the well was developed, a Geoguard Model No. 5614 dedicated monitoring well pump was installed on $8 / 16 / 90$ at a depth of 61.6 feet below ground surface. These pumps are decontaminated at American Sigma and are sent prepackaged. A copy of the pump certification is kept on file at ORNL.

\subsection{Hydraulic conductivity resting}

Well number 1140 was tested for the determination of hydraulic conductivity of the aquifer in the vicinity of the well screen. This was accomplished by instantaneously adding a known quantity of water to the monitoring well and measuring the recovery of the water level over time. The changing water levels were measured using a Druck 15 psi pressure transducer and an Omnidata Datapod II data recorder. The hydraulic conductivity value of $1.17 \times 10^{-4} \mathrm{~cm} /$ second (shown as permeability on the hydraulic conductivity calculations printout attached) was calculated using the Bouwer and Rice method. A computer printout of the hydraulic conductivity calculations is included in this data package. 


\section{PRE-DRILLING CHECKLIST FOR MONITORING WELLS}

BRE-ORILUNG TASKS

1. EXCAVTION PERMIT OBTAINED

2. ALL EQUIPMENT HAS BEEN CLEANED BEFORE DRILLING.

30. SCREEN AND CASING HAVE BEEN WASHED, STEAMED, RINSED WITH DE-IONIZED OR DISTILLED WATER, RINSED WTH ISOPROP N ALCOHOL, WRAPPED WIH PROTECTVE COVERING AND STORED OFF THE GROUND.

36. PRE-PACKAGED SCREENS, CASING AND CENTRALIZERS WERE USED.

4. WORK AREA FOR SAMPLE EXAMINATION COVERED WTH CLEAN POL TETHRENE.

5. CLEAN KNIVES, GLOVES, SAMPLE JARS AND LABELS ON HAND.

6. POLYETHRENE COVER IN PLACE OVER HOLE.

7. AIR ROTARY COMPRESSED AIR SAMPLED.
COMPLIANCE

\begin{tabular}{|c|c|}
\hline $\begin{array}{c}\text { DAIE } \\
01-31-90\end{array}$ & $\frac{1 N 174 L}{102}$ \\
\hline $03-02-90$ & The \\
\hline$N / A$ & \\
\hline
\end{tabular}

03-05-90 Th

03-02-90 12

$03-02-90$

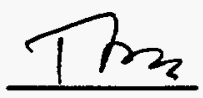

$\underline{03-05-90}$

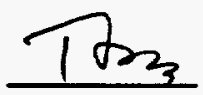

$03-05-90$

RESUL TS: No hydrocarbons detected under ultraviolet 1ight.

ADOITONAL NOTES/OBSERVATIONS:

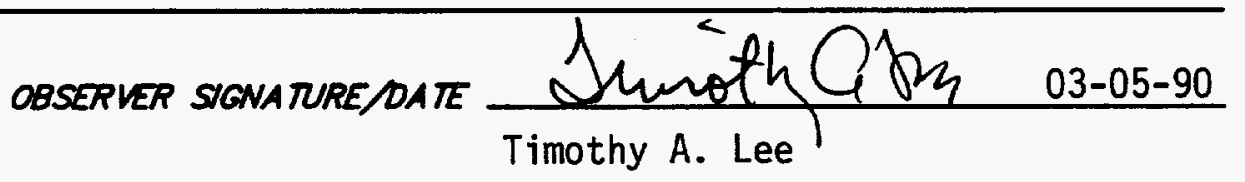

PAGE 6 of 18. 


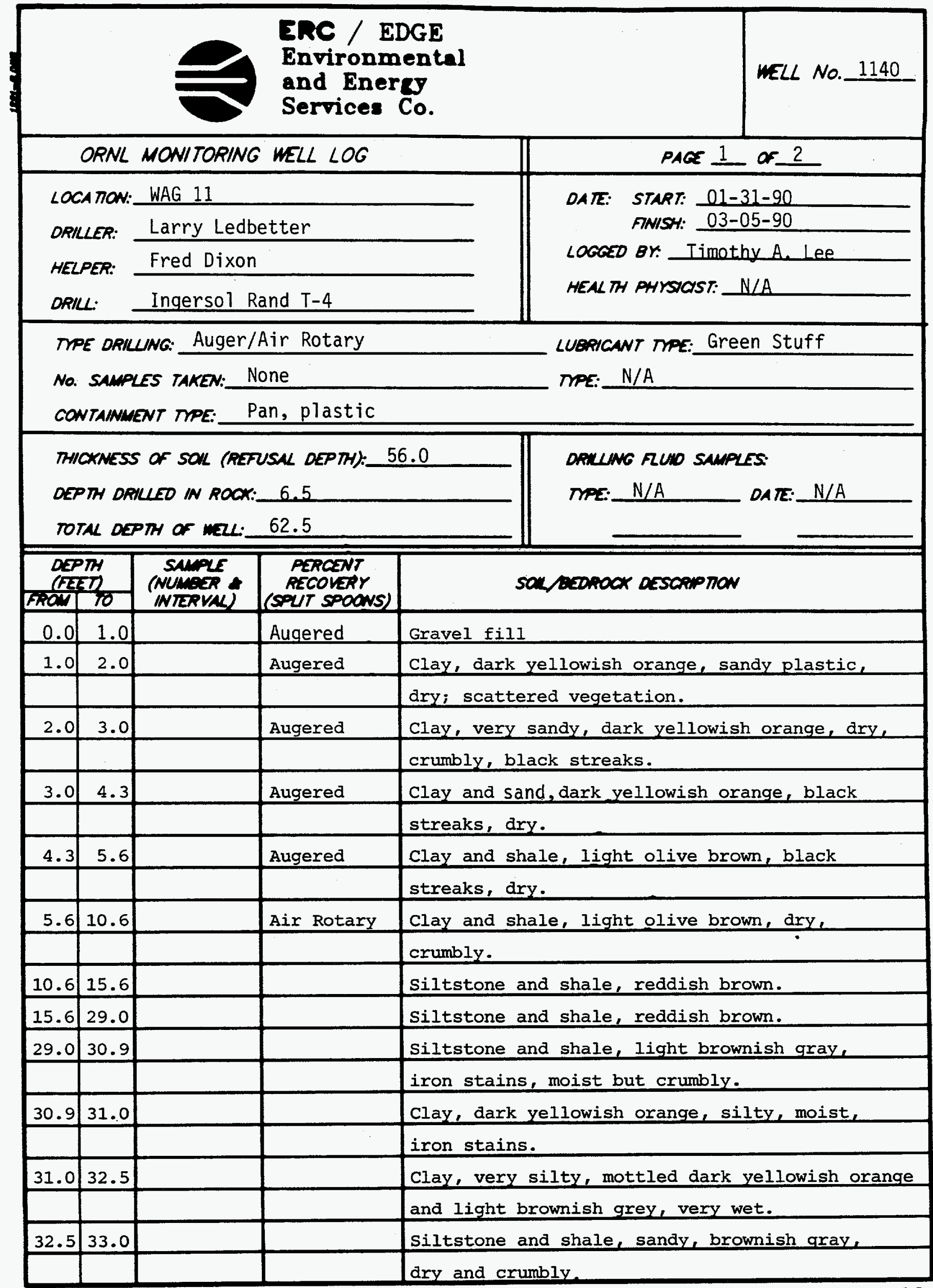




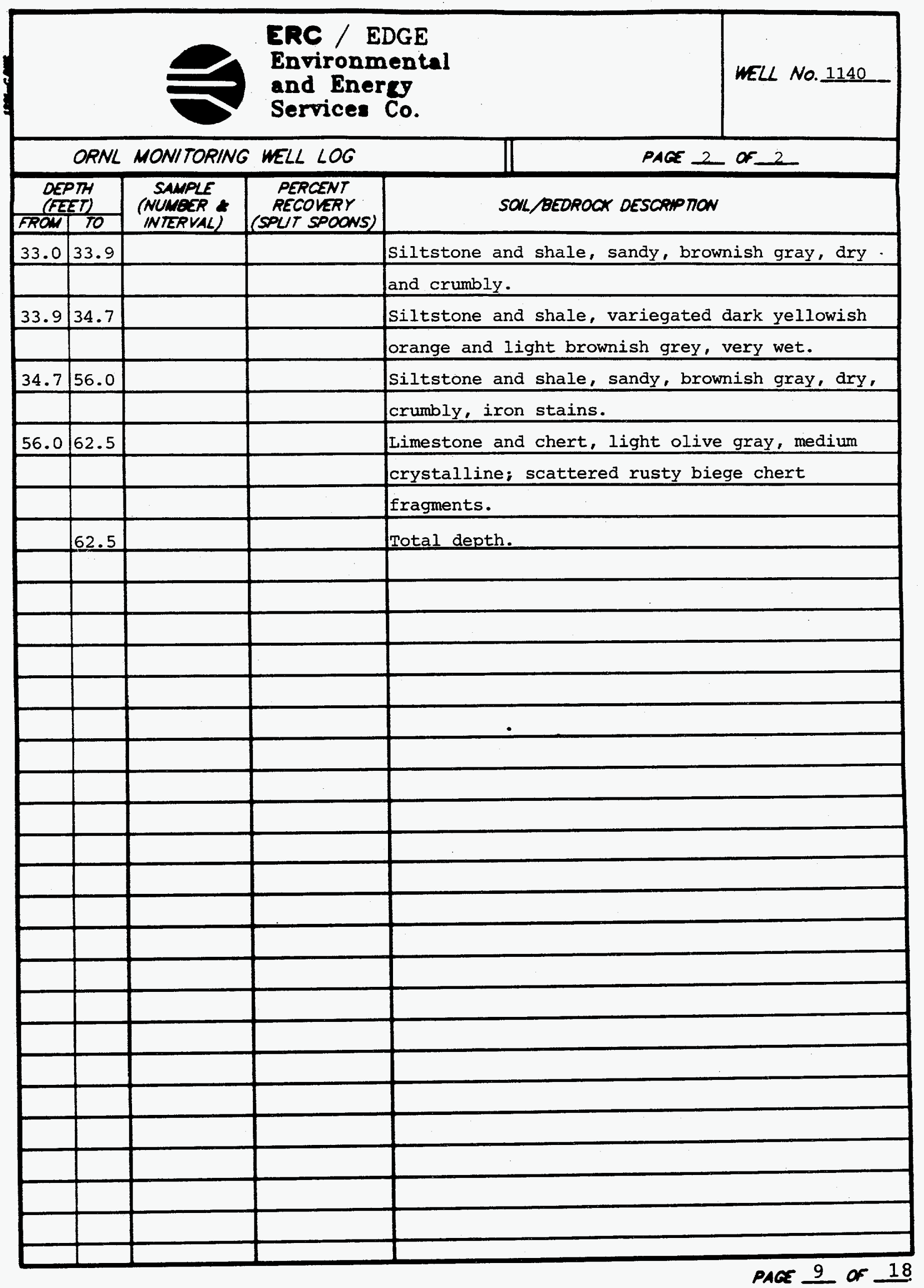




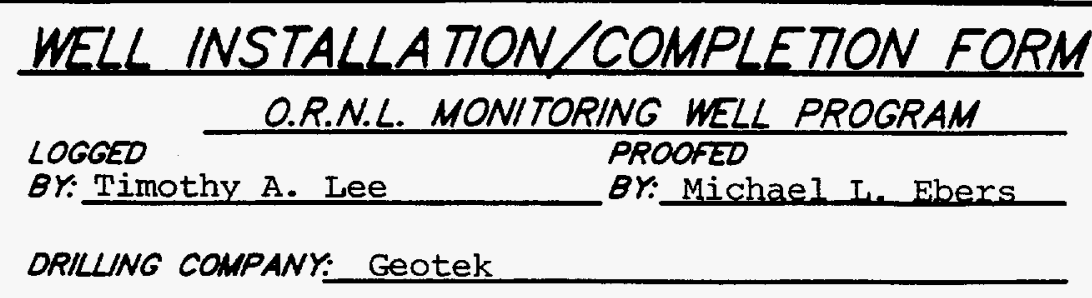

ORILER: Larry Ledbetter HELPER:_Ered Dixon
14.0 INCH AUGER
INCH AUGER - 8.0 INCH ROTARY 56.5

\section{MATERIALS USED}

EST. USED

VOL. VOL.

30.0 FEET OF 2.0 NN. S.S. SCREEN

35.0 FEET OF 2.0 IN. S.S. CASING

9.712 .0 SACKS OF SAND

50.050 .0 POUNOS OF BENTONITE PELLETS

5.6 7.0 SACKS OF CEMENT

35.0 POUNDS OF POWDERED BENTONITE

56.0 GALLONS OF WATER (CEMENTNG)

REASON FOR DIFFERENCES BETWEEN ESTMATED VOLUMES AND USED VOLUMES

Fractures and irregular boring diameters.

\begin{tabular}{|c|c|}
\hline ware coler uses & 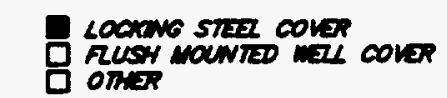 \\
\hline סמקו T"X & KES \\
\hline
\end{tabular}

MONITORING MELL PUMP BASE SET AT 61.6 FEET.

$$
\begin{aligned}
\text { CENTRALIZERS AT } \frac{22.0}{\frac{41.0}{60.0} \text { FEET. }} \text { FEET. } \\
\text { FEET. }
\end{aligned}
$$

NOTE:

ALU DEPTHS ARE MEASURED

FROW GROUND SURFACE

UNLESS OTHERMSE NOTED:

\section{TYPE D WELL} Dotrow of bavarace
LOCA RON WAG 11 ORNL QRID COOROINATES $N \quad 34,497,9754$ $E 28,111.2064$ ELEV. GROUNO 871.89 ELEV. TOP STAINLESS STEEL CASING 873.98 DRILLING DATES: STARTED: $01-31-90$ FNISHED: $03-05-90$ LOOXNG STER COVER $L F$. L.F.
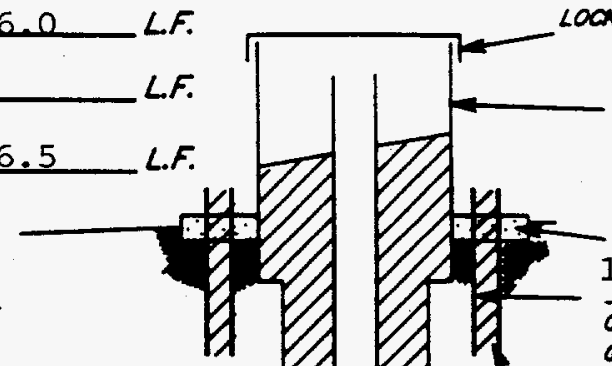
10 NOH OMMETER STER PROTECTVE CASING 3.01_T. ABOVE CROUNO To م.م. Bezow GoUNO suRACE

CP= cavarese PAO $103 / 4$ MOH OIERTER GASIVG O. TT. ABOVE GPOUND SUAFACE TO 6.0 FT. BLIOW CPOUND SUAFACE

-14.0 war Boretral $0.0 \pi 6.0$ RET $\cos \operatorname{sen} 0.0$ To 29.0 AIET 8.0 NOW OMAETER Boretor 2 NOH OHAMETER STANLESS STEZ CASING 2.09 RT. AOOVE erouno suarace to 32.2 rt. ezow Grouno sliosace

CENTRNUES (TPP.)

BSTROWTE PELET SEN 29.0 r0 10.5 fख्या $30.5^{\text {SACX }} 62.5$ NEET 2 Avar ounctor stankess sime 0070 SOTIED SaEgeN $322 \pi 62.3$ FET

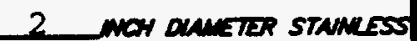
strI ST TRP/CAP $62.3 \pi 62.5$ भथा NOT TO SCALE 
ERC / EDGE

Environmental

WELL NO. 1140

and Energy

Services Co.

DA TE: $03-05-90$

\section{MONITORING WELL MATERIALS CERTIFICATION}

\begin{tabular}{|c|c|c|}
\hline ITEM/MA TERIAL & DATE USED & BATCH NUMBER \\
\hline SAND & $03-05-90$ & 3 \\
\hline \multirow{2}{*}{ BENTONITE } & $03-05-90$ & 1 \\
\hline & $03-06-90$ & 6 \\
\hline (PREPACKAGED $\left.0 \begin{array}{cc}\text { YES } \\
\text { NO }\end{array}\right)$ & $03-05-90$ & 3 \\
\hline $\begin{array}{lll}\text { STAINLESS STEEL CASING (PREPACKAGED } & \text { YES } \\
\text { NO }\end{array}$ & $03-05-90$ & 3 \\
\hline STAINLESS STEEL CENTRALIZERS (PREPACKAGED D VES) & $03-05-90$ & 2 \\
\hline $\left.\begin{array}{lll}\text { STAINLESS STEEL CAPS } & \text { (PREPACKAGED } & \text { VES } \\
\text { NO }\end{array}\right)$ & $03-05-90$ & 2 \\
\hline (PREPACKAGED $\left.0 \begin{array}{c}\text { YES } \\
\text { NO }\end{array}\right)$ & $08-06-90$ & 8 \\
\hline \multirow{2}{*}{ GROUT } & $01-31-90$ & 6 \\
\hline & $03-06-90$ & 6 \\
\hline \multicolumn{3}{|l|}{ WELL COVERS } \\
\hline SURFACE CASING/DIVERTER CASING & $01-31-90$ & 4 \\
\hline
\end{tabular}

COMMENTS:

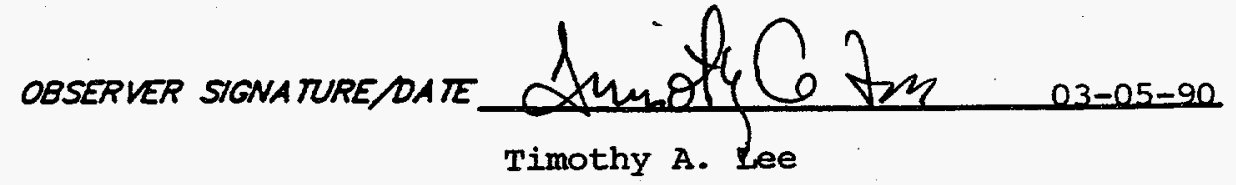

PAGE 11 or 18 . 


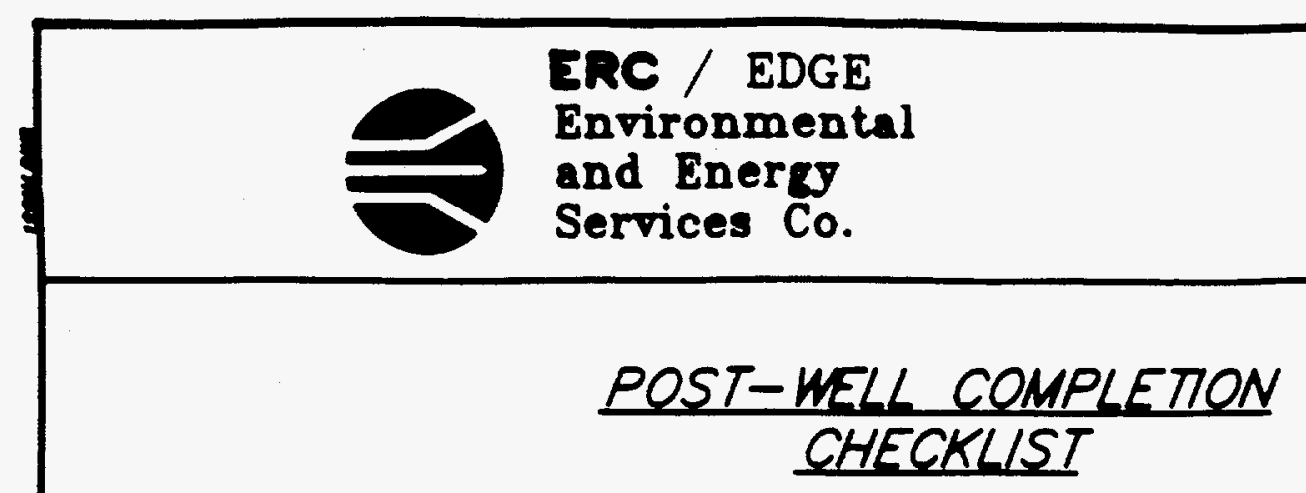

\section{POST-MELL COMPLETION TASKS}

1. WO SCRAPED FROW AUCERS SMMPLERS AND AL
OTHER EOUPMENT.

1. WU SCPAPED FRON AUCERS SAMPLERS AND ALI
OTHER EOUIPNENT.

$$
\begin{aligned}
& \text { COMPLIANCE } \\
& \text { DA.T INITALS }
\end{aligned}
$$

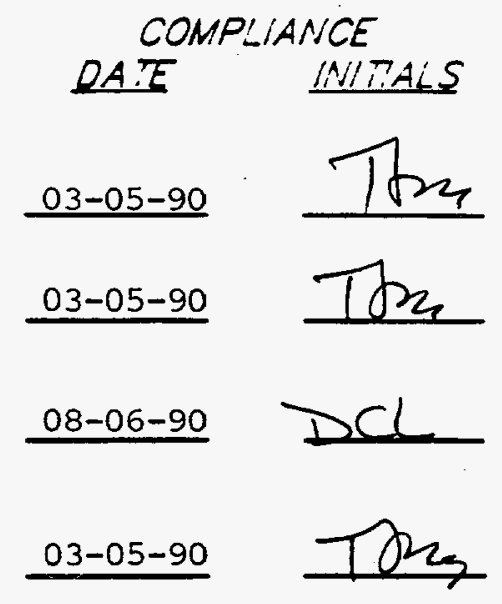

2. ALL WUO FRON RIG AND EQUMPUNT SCRAPNGS ANO CUTMNGS DISPOSED OF $W$ ACCORDANCE MTH THE SPECIFCA IION* PROMaco.

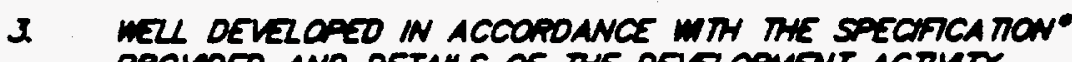
PROVOED ANO DETALS OF THE OEVZLOWENT ACHUT AECOROED.

4. DPULNG STE PROPERL Y QEAMED UP AFTER completion or izL INSTALUATON.

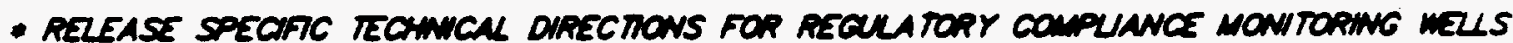
PHASE 1, OAK RIDEE NA HONAL LAOORA TORY, OAK RDOES M.O. K-4147, APAK 1967.

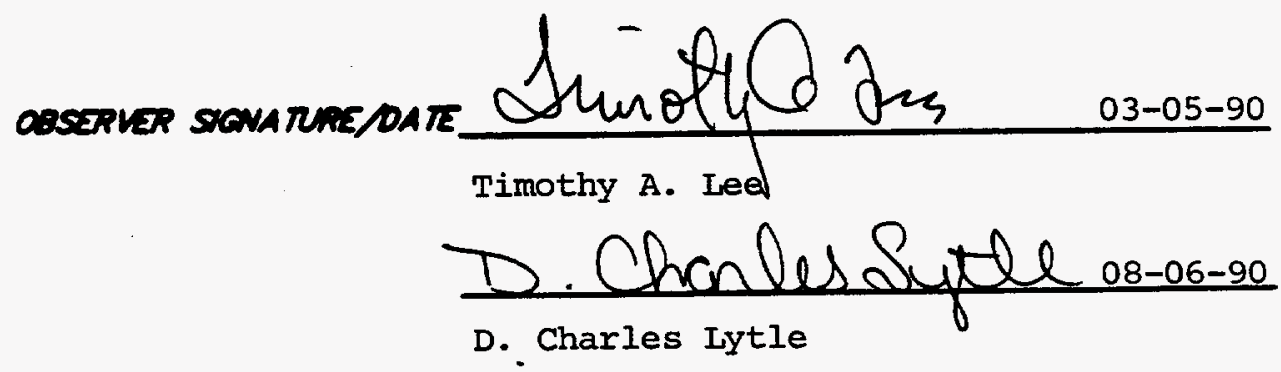




\section{ERCE}

Environmental

and Energy

WELL NO. 1140

Services Co.

\section{MONITORING WELL \\ DEVELOPMENT FORM}

DEVELOPMENT DETAILS

METHOD OF

DEVELOPMENT: Surging and Pumping

DEVELOPMENT

BEGAN DATE: $\quad 08-03-90$

TME:

DEVELOPMENT

ENOING DATE: $\quad 08-06-90$

DEVELOPMENT

OBSERVED BY: D. Charles Lytle

ONE WELL VOLUME: 152 GALLONS

TOTAL GALLONS PUMPED: 120 TOTAL MELL VOLUMES PUMPED: 8.0

INITAL PH: 8.2 FNAL PH: 8.8

INITAL CONOUCHUTY ( $\mu \mathrm{S} / \mathrm{cm}): 226$ FNAL CONDUCHUTY $(\mu \mathrm{s} / \mathrm{cm}): 279$

DESCRIPTION OF INITAL TURBIOITY:ClOOUdY

DESCRIPTION OF FNAL TURBIOITY:_Clean

FINAL MEASURED TURBIOIT: 4.0 NTU's

WELL APPROVED BY: R.C. Williams MMES

ODOR

QF WATER: NONE

WATER

DISCHARGED

TO:

GROUND SURFACE

口 STORN SEWERS

D DRUMS

\section{口 TANK TRUCK \\ 口 STORAGE TANKS \\ 口 OTHER}

INITAL PRE-DEVEZOPMENT

WATER DEPTH: 51.1 feet from ground surface.

DEVELOPMENT OBSERVA TONS

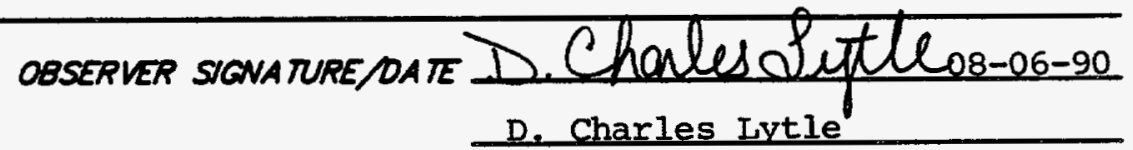




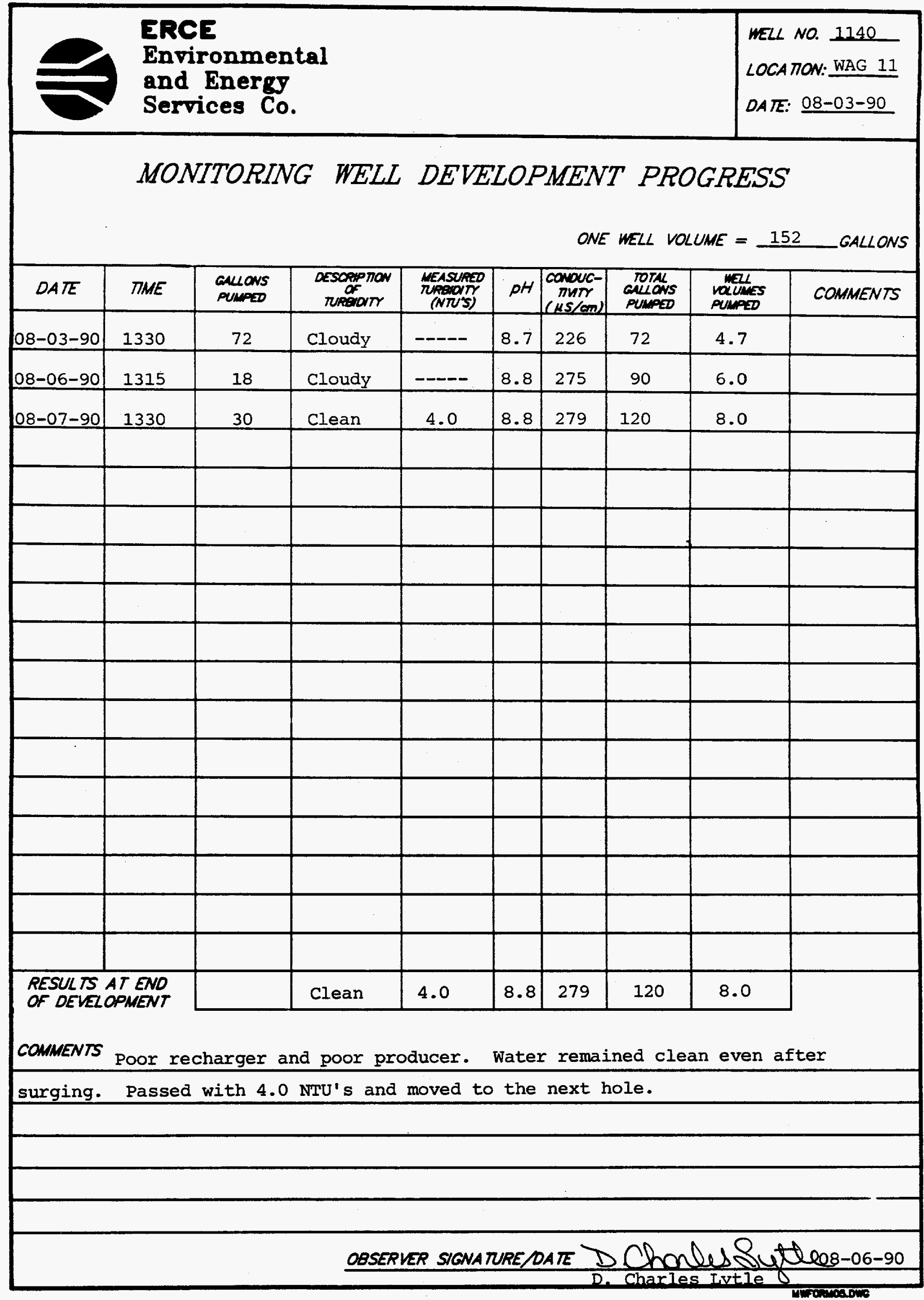

PAGE 14 OF 18. 


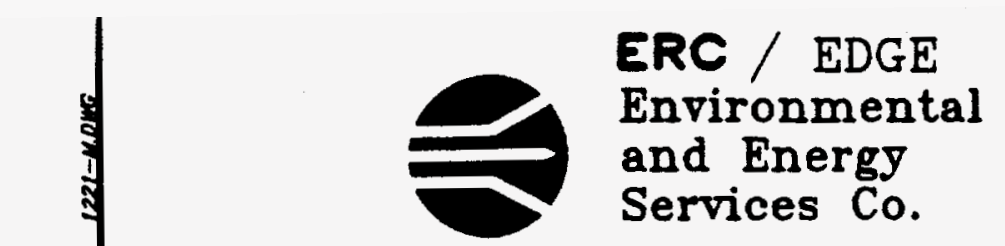

\section{HYDRAULIC CONDUCTIVTY CALCULATIONS}

PROGRAM SLUGT, VERSION 4.1, NOV. 1986

THIS PROGRAM CALCULATES MEAN TRANSMISSIVITIES FROM SLUG-TEST DATA BASED ON TWO ANALYTICAL APPROACHES:

(1) METHOD OF COOPER, BREDEHOEFT AND PAPADOPULOS, 1967 (ARTICLE IN VOL.3, NO. 1 OF WRR ENTITLED

"RESPONSE OF A FINITE DIAMETER WELL TO AN INSTANTANEOUS CHARGE OF WATER")

(2) METHOD OF BOUWER AND RICE, 1976 (ARTICLE IN VOL. 12 , NO.3 OF WRR ENTITLED

"A SLUG TEST FOR DETERMINING HYDRAULIC CONDUCTIVITY OF UNCONFINED AQUIFERS WITH COMPLETELY OR PARTIALLY PENETRATING WELLS")

WELL NO.: 1140

DATE OF TEST: $9-20-90$

PROJECT NO.: E221-002

CLIENT: MMES

SITE LOCATION: WAG-11

EDGE, INC. FIELD INVESTIGATOR: JAMES W. CARUTHERS

INPUT DATA ARE:

INNER CASING DIAMETER $=2.00$ INCHES

INNER SCREEN OR OPEN-HOLE DIAMETER $=2.00$ INCHES

DIAMETER OF DRILLED HOLE $=8.00$ INCHES

LENGTH OF SCREEN OR INTAKE PORTION $=30.00$ FEET

DEPTH FROM STATIC LEVEL TO BOTTOM OF SCREEN $=8.99$ FEET

THICKNESS OF SATURATED AQUIFER ZONE $=30.00$ FEET

DEPTH TO STATIC WATER LEVEL BELOW REF. POINT $=8.00$ FEET

ESTIMATED POROSITY OF GRAVEL PACK $=.20$

FALLING-HEAD INDEX $=0$ ("1" IF FALLING, "0" IF RISING)

NUMBER OF DEPTH-TIME DATA POINTS $=24$

HO WAS COMPUTED FROM INTERCEPT OF PLOT OF LOG(H) VS. TIME

$$
\begin{aligned}
& \text { SUCCESSIVE COMPUTED } \\
& \text { VALUES FOR HO } \\
& \text { (FEET) } \\
& .5868 \\
& .5964
\end{aligned}
$$

VALUES FOR HO 


\section{HYDRAULIC CONDUCTIVTY CALCULATIONS}

$\begin{array}{rrr}\text { TIME } & \text { DEPTH TO WATER } & \begin{array}{r}\text { HEAD } \\ (\text { SEC }\end{array} \\ \text { (FEET) }\end{array}$




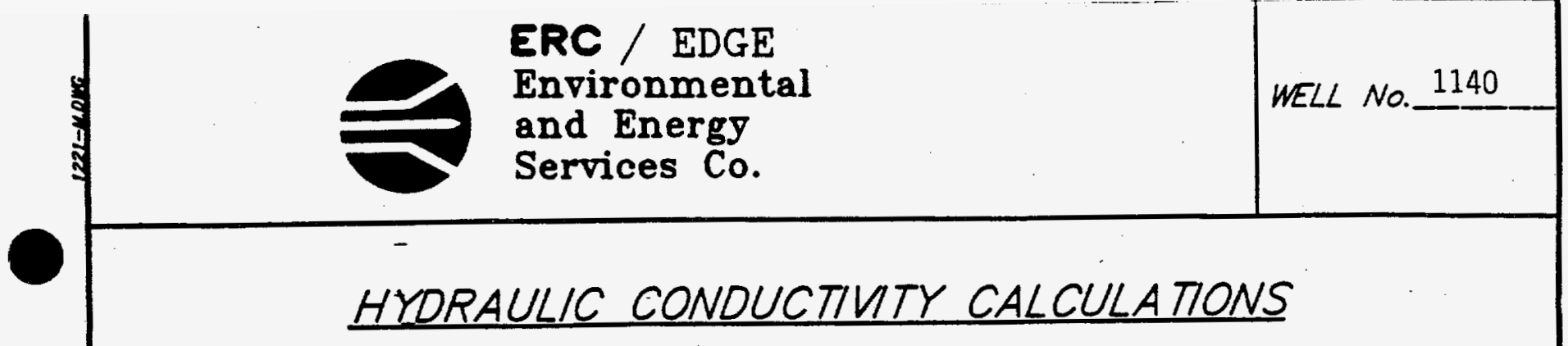

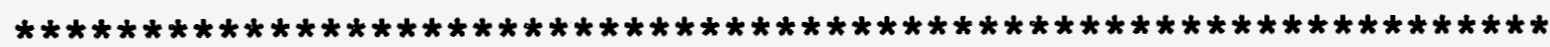 METHOD OF BOUWER AND RICE
COMPUTED RESULTS USING DIAMETER OF DRILLED HOLE:
PERMEABILITY $=3.83 \mathrm{E}-06 \mathrm{FT} / \mathrm{SEC}=1.17 \mathrm{E}-04 \mathrm{CM} / \mathrm{SEC}$ TRANSMISSIVITY $=1.15 \mathrm{E}-04 \mathrm{FT} * 2 / \mathrm{SEC}$

COMPUTED RESULTS USING DIAMETER OF CASING AND SCREEN:

PERMEABILITY $=1.45 \mathrm{E}-06 \mathrm{FT} / \mathrm{SEC}=4.41 \mathrm{E}-05 \mathrm{CM} / \mathrm{SEC}$
TRANSMISSIVITY $=4.34 \mathrm{E}-05 \mathrm{FT} * 2 / \mathrm{SEC}$


ERCE

Environmental

and Energy

WELL No. 1140

Services Co.

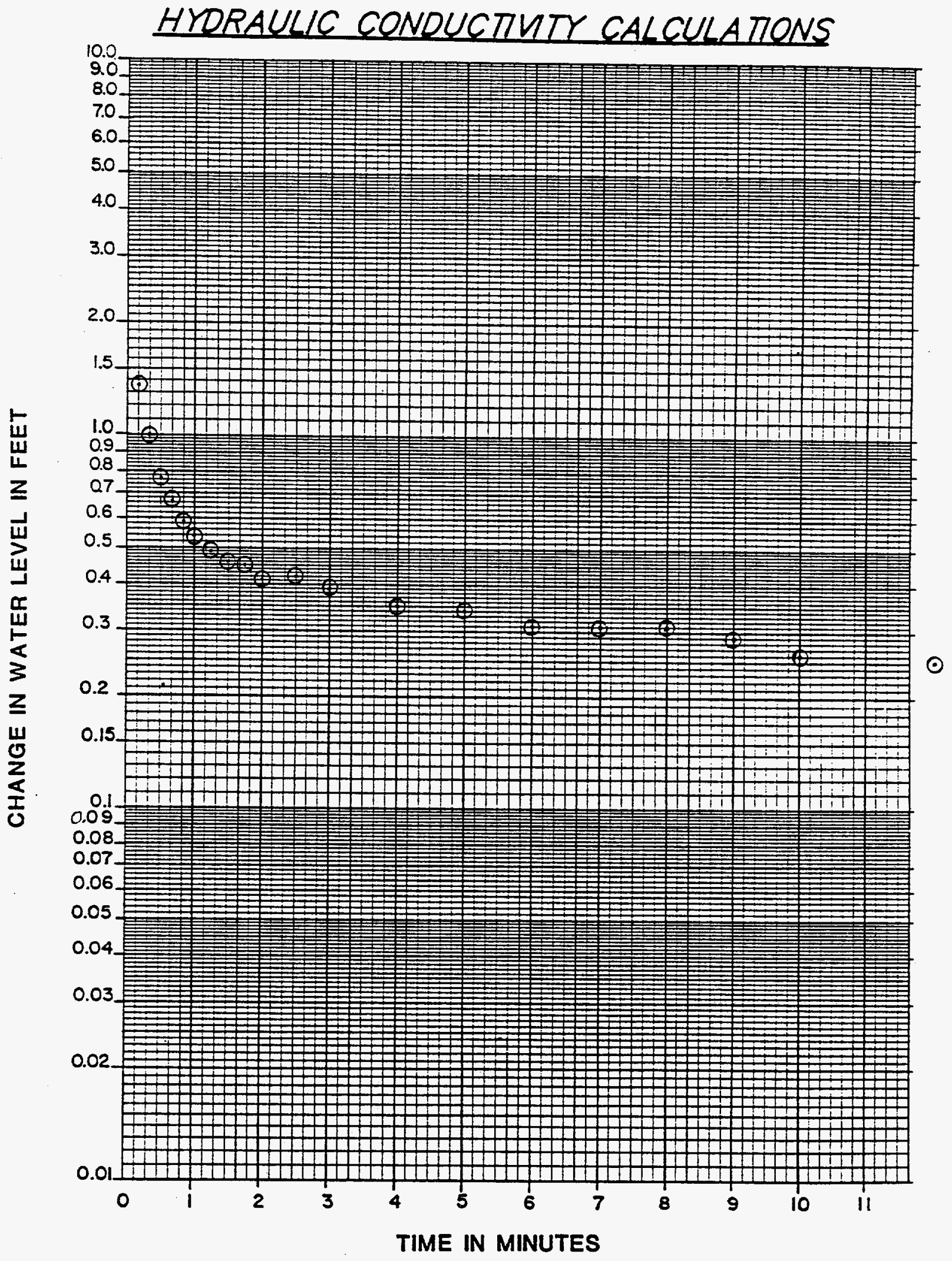

PACE 18 of 18 
ERC / EDGE

Environmental

and Energy

Services Co.

\subsection{Well Location}

Monitoring well number 1141 is located in WAG 11. It is located in the southern boundary of "White Wing scrap Yard" or WAG 11. The location is shown on ORNL drawing number C3E20004A075. Survey coordinates for this well are $\mathrm{N} 34,488.6430, \mathrm{E} 28,148.8969$ (X-10 grid) or latitude $35^{\circ}-57^{\prime}-02.30^{\prime \prime}$ and longitude $84^{\circ}-20^{\prime}-54.38^{\prime \prime}$. Coordinate data were provided by Martin Marietta Energy systems. The method used for conversion from $x-10$ grid to Tennessee-Lambert state Plane Coordinates came from the publication "Tennessee Valley Authority Data Services Branch and Mapping Services Branch, Oak Ridge, Tennessee, DOE Plant Control, November 6, 1985, Field Book: ESS-3115, pp. 1-20." The latitude and longitude were calculated by Adams Craft Herz Walker Engineering, Inc., using methods from the U.S. Coast and Geodetic survey Publication 62-4, "State Plane coordinates by Automatic Data Processing."

\subsection{Drilling Information}

Well number 1141 was drilled by Geotek Engineering Company. An Ingersoll Rand $\mathrm{T}-4 \mathrm{rig}$ was used to drill this boring for monitor well installation under operation of Larry Ledbetter with the assistance of Fred Dixon. Drilling commenced on 1-30-90 and was finished on 2-14-90. Paragraph 2.4.1 includes a detailed discussion of the well installation and a well schematic is included on the well installation/completion form. A synopsis of 
the drilling activity follows. This information was typed directly from field notes and was edited only when necessary for clarification.

1-30-90 The rig was mobilized to location and set up on plastic sheeting. Split spoon samples were taken from surface to first refusal at 5.6 feet. The boring was deepened with a 6 -inch auger to 29.0 feet. Split spoons were taken from 29.0 feet to refusal at 34.7 feet. The boring was deepened from 34.7 feet to refusal at 58.0 feet using a 6-inch auger. Six feet of 15 1/4-inch decontaminated diverter casing was set and grouted. The rig was moved from location.

2-8-90 The rig was moved to location. Drill from 6.0 feet to 60.5 feet using a 14 1/2-inch air rotary tricone bit. Set 60.5 feet of $103 / 4-$ inch decontaminated steel surface casing and grouted it to surface. The rig was moved from location.

2-14-90 Move rig to location. Drill from 60.5 feet to 97.5 feet using an 8-inch air rotary tricone bit. Set 97.4 feet of 4-inch stainless steel screen and casing with sandpack and bentonite seal.

2-15-90 Grouted stainless steel casing annulus with 17 sacks cement.

This well was logged by ERC Environmental and Energy Services Co., Inc., hydrogeologist Timothy A. Lee. All well construction materials and supplies were from Martin 
Marietta Energy Systems approved batches. The batch origin of individual items is shown on the included Monitoring Well Materials Certification form.

\subsection{Technical Information}

\subsection{Decontamination Procedures}

The drilling rig, down hole tools, surface casing, stainless steel screen, stainless steel casing, centralizers, and stainless steel silt trap underwent the cleaning decontamination procedures outlined in the drilling specifications (Release Specific Technical Directions for Regulatory Compliance Monitoring Wells Phase 1, Oak Ridge National Laboratory, Oak Ridge, W.O., K-4147, April 1987, pgs, 2-4). A checklist of the cleaned materials is included with this data package.

\subsection{Geology}

The northeastern half of WAG 11 is underlain by Chickamauga Iimestone. The Rome Formation underlies the southwestern half of WAG 11. The Chickamauga Limestone is brought into contact with the Rome Formation by the White Oak Mountain thrust fault, the trace of which bisects WAG 11 from northwest to southeast. The lowermost beds of the chickamauga are composed of thin bentonitic beds, gray clay shale, and maroon to gray calcareous siltstone. The majority of the Chickamauga, approximately 1,500' thick, is a dominantly gray, dense, finely crystalline, thin bedded limestone with varying amounts of chert. The uppermost beds consist of yellow 
ERC / EDGE

Environmental

and Energy

Services Co.

and maroon calcareous siltstone and blue-gray limestone.

The Rome Formation is composed of interbedded sandstone, siltstone, shale and locally, dolomite.

\section{3 sample collection}

One soil sample was collected during drilling, placed in an I-CHEM specialty cleaned glass container, sealed and submitted to Sample Receiving, Analytical Chemistry Division, Bldg. 4500S, ORNL. A chain of custody form for this sample is included with this data package. Soil sample 1141501 was collected in the split spoon interval from $4.0^{\prime}$ to $4.3^{\prime}$ on $1-30-90$.

A bulk density soil sample was collected from the split spoon sample interval from $3.5^{\prime}$ to $3.8^{\prime}$. The sample was measured, weighed and a bulk density of 2.11 grams $/ \mathrm{cm}^{3}$ was calculated.

The Ingersoll Rand T-4 compressed air was sampled with a cloth filter inserted between drill rods on 2-14-90. The sample was examined with an ultraviolet light for the presence of hydrocarbons. The filter showed no detectable signs of hydrocarbons.

\subsection{Installation and Development}

\subsubsection{Installation}

This was a Type B well. A 22.0-inch diameter boring was augered from ground surface to 6.0 feet. A $151 / 4$-inch diverter casing was installed from surface to 6.0 feet below ground surface and grouted in place. The boring was then extended past the refusal depth with a 14.5-inch 
air rotary tricone roller bit from 6.0 feet to 60.5 feet. A 10 3/4-inch diameter string of decontaminated steel surface casing was installed from 0.0 feet to 60.5 feet, sealed with a 1.5 foot bentonite pellet layer from 59.0 feet to 60.5 feet, and tremie grouted in place. The surface casing minimizes potential cross contamination between the regolith and bedrock water bearing zones. After the surface casing was installed, the air rotary method was used to drill an 8-inch diameter boring to a total depth of 97.5 feet. A 4-inch diameter stainless steel screen with threaded bottom cap was installed from 82.2 feet to 97.4 feet. A 4-inch diameter stainless steel casing was installed from the top of the screen at 82.2 feet and extended 2.8 feet above ground surface. A sandpack was then tremied into the annular space from 77.9 to 97.4 feet, with a 1.8 foot bentonite pellet seal poured into the annular space above the sandpack from 76.1 to 77.9 feet. The annular space from the top of the bentonite seal to the surface was tremie grouted with a cement/bentonite slurry. A detailed schematic of the well is included on the well installation/completion form.

\subsubsection{We11 Development}

Well number 1141 was developed to remove drill cuttings, silt, and other fines. The monitoring was developed using a Geoguard pump with an air compressor. All pumps were cleaned prior to use according to specified cleaning procedures (see Paragraph 2.1). The well was developed until a measured total of 160 gallons of water had been evacuated and the clarity of the discharge water was approved by the company representative. The final turbidity value measured at completion was 4.0 NTU's. A 
development form showing the exact method of development and other pertinent data is appended.

2.4.3 Installation of Dedicated Monitoring Well Pump

After the well was developed, a Geoguard Model No. 5614 dedicated monitoring well pump was installed on $7 / 27 / 90$ at a depth of 89.8 feet below ground surface. These pumps are decontaminated at American Sigma and are sent prepackaged. A copy of the pump certification is kept on file at ORNL.

\subsection{Hydraulic Conductivity Testing}

Well number 1141 was tested for the determination of hydraulic conductivity of the aquifer in the vicinity of the well screen. This was accomplished by instantaneously adding a known quantity of water to the monitoring well and measuring the recovery of the water level over time. The changing water levels were measured using a Druck 15 psi pressure transducer and an omnidata Datapod II data recorder. The hydraulic conductivity value of $1.45 \times 10^{-4} \mathrm{~cm} / \mathrm{sec}$ nd (shown as permeability on the hydraulic conductivity calculations printout attached) was calculated using the Bouwer and Rice method. A computer printout of the hydraulic conductivity calculations is included in this data package. 


\section{PRE-DRILLING CHECKLIST FOR MONITORING WELLS}

RRE-DRILUNG TASKS

1. EXCAVTION PERMIT OBTAINEO

\begin{tabular}{|c|c|}
\hline \multicolumn{2}{|c|}{ COMPLIANCE } \\
\hline$D A T E$ & \\
\hline $01-30-90$ & 24 \\
\hline $01-30-90$ & $x_{4}$ \\
\hline $\mathrm{N} / \mathrm{A}$ & $\mathrm{N} / \mathrm{A}$ \\
\hline
\end{tabular}

30. SCREEN AND CASING HAVE BEEN WASHED, STEAMED, RINSED WTH DE-IONIZED OR DISTLLED WATER, RINSED WTH ISOPROPN ALCOHOL, WRAPPED WTH PROTECTVE COVERING AND STORED OFF THE GROUND.

36. PRE-PACKAGEO SCREENS, CASING AND CENTRALIZERS WERE USED.

4. WORK AREA FOR SAMPLE EXAMINATION COVERED WTH CLEAN POL KETHIENE.

5. CLEAN KNIVES, GLOVES, SAMPLE JARS AND LABELS ON HAND.

6. POL YETHILNE COVER IN PLACE OVER HOLE.

$\underline{01-30-90}$

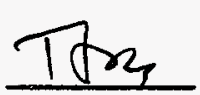

$02-14-90$

$01-30-90$

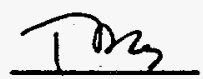

$01-30-90$

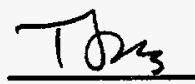

7. AIR ROTARY COMPRESSED AIR SAMPLED.

$02-14-90$

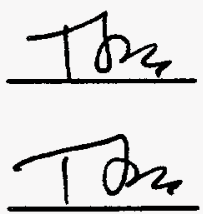

RESUL TS: No detectable hydrocarbons under ultra violet light.

ADDITINAL NOTES/OBSERVATONS:

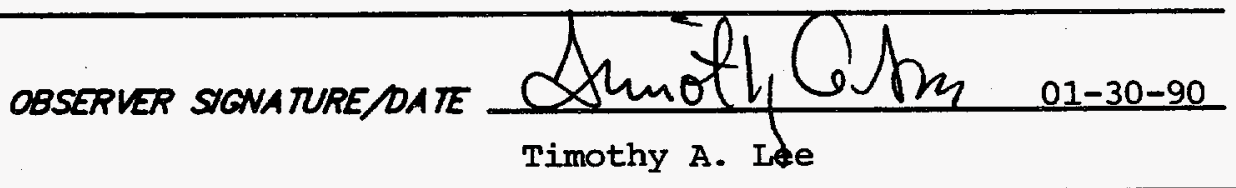

PAGE 7 of 22 . 
$\frac{\text { DECONTAMINATION CHECKLIST }}{\text { DRILLING EQUIPMENT }}$

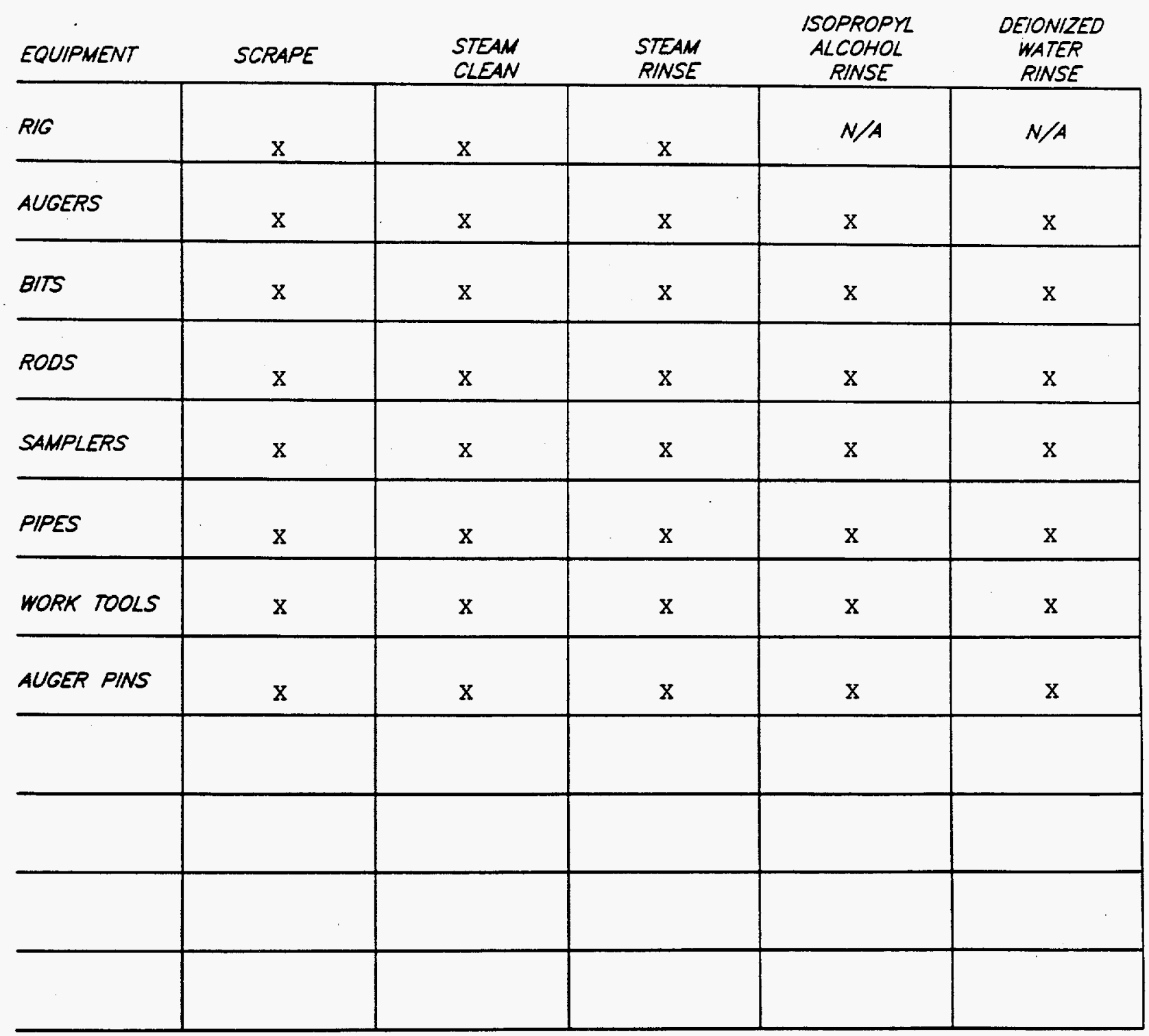

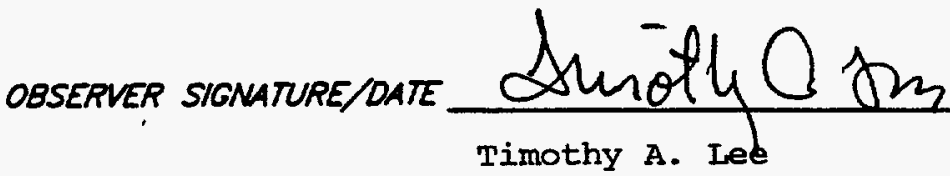
02-14-90 


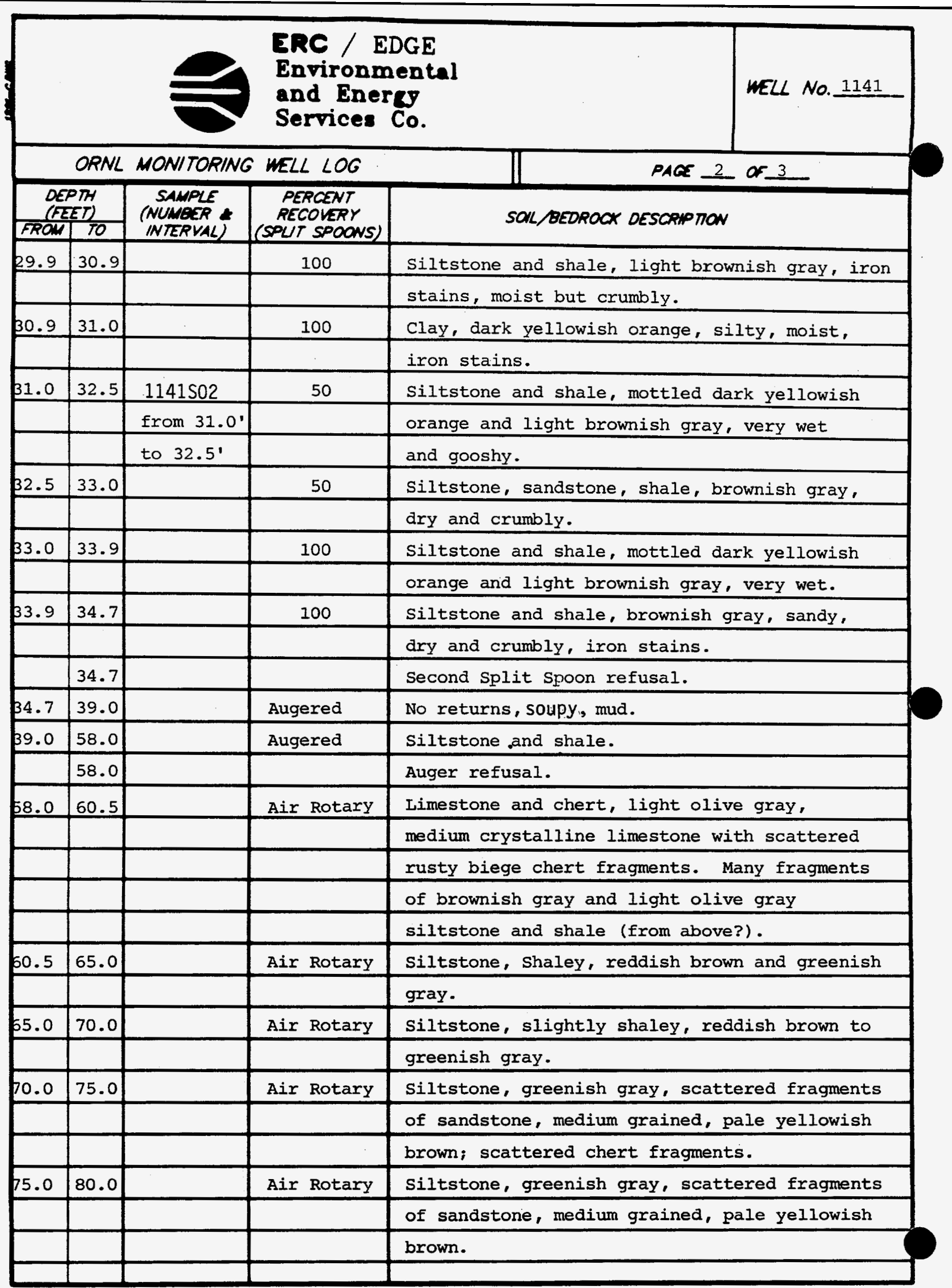




\begin{tabular}{|c|c|c|c|c|}
\hline \multicolumn{5}{|c|}{$\begin{array}{l}\text { ERC / EDGE } \\
\text { Environmental } \\
\text { and Energy } \\
\text { Services Co. }\end{array}$} \\
\hline \multicolumn{5}{|c|}{ ORNL MONITORING WELL LOG } \\
\hline \multicolumn{2}{|c|}{\begin{tabular}{|c|}
\multicolumn{2}{|c|}{ OEPTH } \\
\multicolumn{2}{|c|}{ (FEET) } \\
FROM
\end{tabular}} & $\begin{array}{l}\text { SAMPLE } \\
\text { (NUMEER A } \\
\text { INTERVAL) }\end{array}$ & $\begin{array}{c}\text { PERCENT } \\
\text { RECOVERY } \\
\text { (SPUT SPOONS) }\end{array}$ & SOL/BEDROCK DESCPIP TON \\
\hline \multirow{3}{*}{30.0} & 85.0 & & & Sandstone and siltstone, slightly shaley, \\
\hline & & & & fine to medium grained, dusky yellowish \\
\hline & & & & brown to moderate yellowish brown. \\
\hline \multirow[t]{3}{*}{35.0} & 90.0 & & & Sandstone and siltstone, slightly shaley, \\
\hline & & & & fine to medium grained, dusky yellowish \\
\hline & & & & brown to moderate yellowish brown. \\
\hline \multirow[t]{3}{*}{90.0} & 95.0 & & & Sandstone and siltstone, fine to medium \\
\hline & & & & grained, dusky yellowish brown to moderate \\
\hline & & & & yellowish brown; scattered fragments of clay. \\
\hline \multirow[t]{4}{*}{95.0} & 97.5 & & & Siltstone and sandstone, moderate yellowish \\
\hline & & & & brown, fine to medium grained, scattered \\
\hline & & & & unconsolidated fragments of clay. \\
\hline & 97.5 & & & Total depth. \\
\hline & & & & \\
\hline & & & & \\
\hline & & & & . \\
\hline & & & & \\
\hline & & & & \\
\hline & & & & \\
\hline & & & & \\
\hline & & & & \\
\hline & & & & \\
\hline & & & & \\
\hline & & & & \\
\hline & & & & \\
\hline & & & & \\
\hline & & & & \\
\hline & & & & \\
\hline & & & & \\
\hline & & & & \\
\hline & & & & \\
\hline & & & & \\
\hline & & & & \\
\hline
\end{tabular}




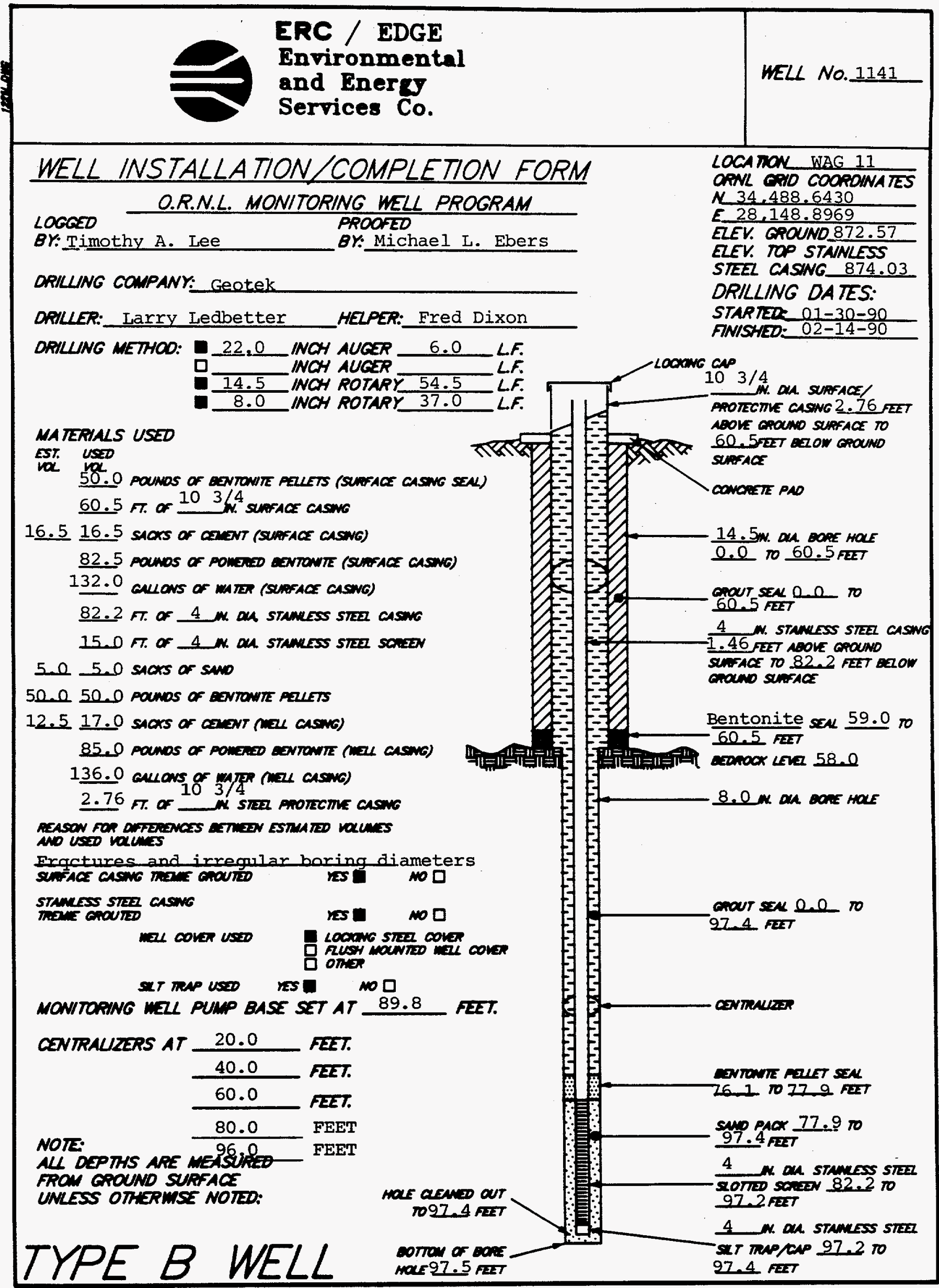

PACE 12 of 22 
ERC / EDGE

Environmental

WELL No. 1141

and Energy

Services Co.

\section{MONITORING WELL MATERIALS CERTIFICATION}

ITEM/MA TERIAL

\begin{tabular}{|c|c|c|c|}
\hline \multirow{2}{*}{\multicolumn{2}{|c|}{ SAND }} & & \\
\hline & & $02-14-90$ & 2 \\
\hline \multirow{2}{*}{ BENTONITE } & \multirow{2}{*}{$\begin{array}{l}\text { Pellets } \\
\text { Powder }\end{array}$} & $02-14-90$ & 1 \\
\hline & & $02-15-90$ & 4 \\
\hline STAINLESS STEEL SCREEN & $\left(\begin{array}{ll}\text { PREPACKAGED } & \text { RES } \\
\text { NO }\end{array}\right)$ & $02-14-90$ & 2 \\
\hline STAINLESS STEEL CASING & $\left(\begin{array}{ll}\text { PREPACKAGED } & \text { YES } \\
\text { NO }\end{array}\right)$ & $02-14-90$ & 2 \\
\hline STAINLESS STEEL CENTRALIZERS & $\left(\begin{array}{ll}\text { PREPACKAGED } & \text { VES } \\
\text { NO }\end{array}\right)$ & $02-14-90$ & 2 \\
\hline STAINLESS STEEL CAPS & $\left(\begin{array}{ll}\text { PREPACKAGED } & \text { YES } \\
\text { NO }\end{array}\right)$ & $02-14-90$ & 2 \\
\hline MONITORING WELL PUMP & $\left(\begin{array}{lll}\text { PREPACKAGED } & \text { YES } \\
\text { NO }\end{array}\right)$ & $07-27-90$ & 8 \\
\hline \multirow{2}{*}{ GROUT } & \multirow[t]{2}{*}{ Surface Casing } & $02-09-90$ & 6 \\
\hline & & $\begin{array}{l}02-15-90 \\
02-16-90 \\
\end{array}$ & 6 \\
\hline \multicolumn{2}{|l|}{ MELL COVERS } & & \\
\hline \multicolumn{2}{|l|}{ SURFACE CASING } & $02-08-90$ & 4 \\
\hline
\end{tabular}

COMMENTS:

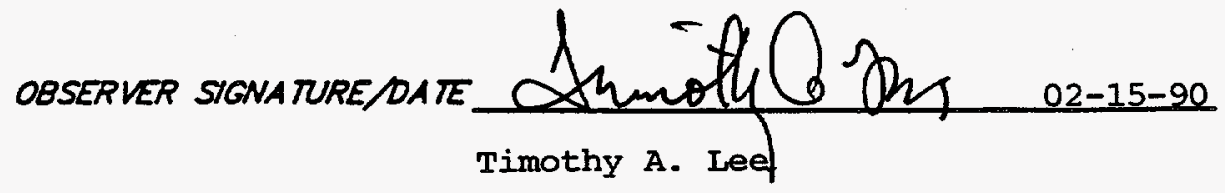

PAGE 13 of 22 


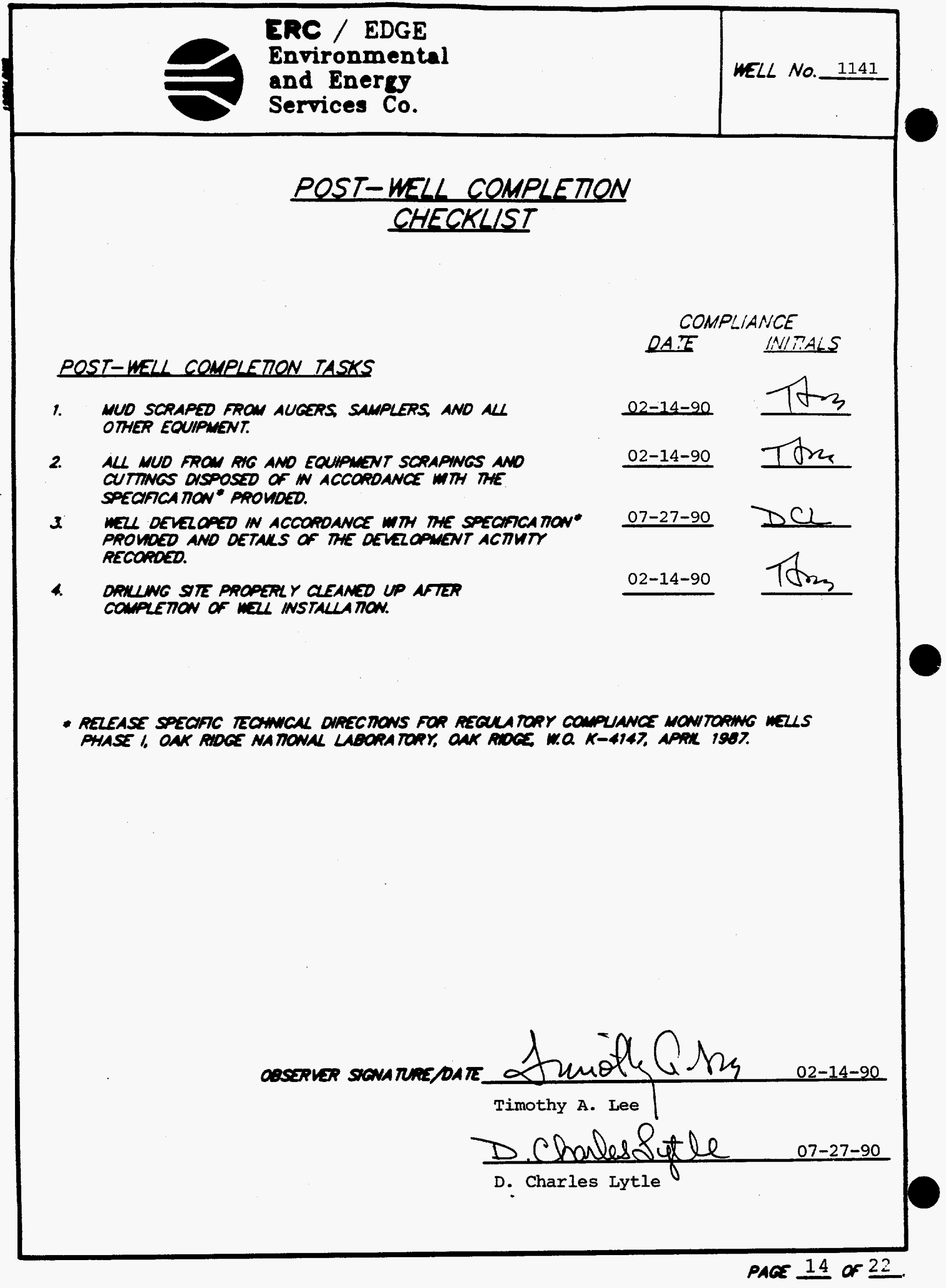




\section{MONITORING WELL \\ DEVELOPMENT FORM}

DEVELOPMENT DETAILS

METHOD OF

DEVELOPMENT: Surging and Pumping

DEVELOPMENT
BEGAN DATE: TME:

DEVELOPMENT

ENDING OATE: $\quad 07-27-90$

DEVELOPMENT

OBSERVED BY: D. Charles Iytle

ONE WELL VOLUME: 40.0 GALLONS

TOTAL GALLONS PUMPED:_ 160 TOTAL WELL VOLUMES PUMPED: 4.0

INITAL PH: 9.1 FNAL PH: 9.1

INIMAL CONOUCTUTY (H S/cm): $369 \quad$ FNAL CONDUCTUTY $(\mu \mathrm{S} / \mathrm{cm}): 369$

DESCRIPTION OF INITAL TUREIOITY: ClEan

DESCRIPTION OF FNAL TURBIOITY:__ Clean

FNAL MEASURED TURBIDITY: 4.0 NTU's.

WEL APPROVED BY: R.C. Williams MMES

OOOR

OF MATER: NOne

WA TER

DISCHARGED

TO:

GROUND SURFACE

O STORN SEWERS

D DRUMS
口 TANK TRUCK

D STORAGE TANKS

Q OTHER

INITAL PRE-DEVELOPMENT

WATER DEP TH: 58.3 feet from ground surface.

DEVELOPMENT OBSERVATIONS

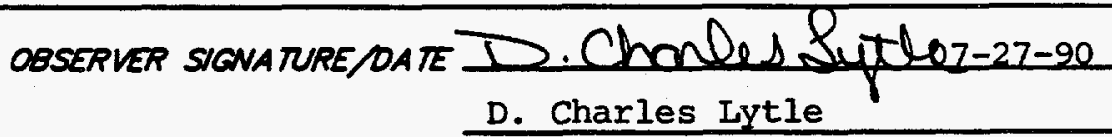




\begin{tabular}{|c|c|c|c|c|c|c|c|c|c|}
\hline$\frac{1}{2}$ & $\begin{array}{l}\text { ERo } \\
\text { Env } \\
\text { and } \\
\text { Ser }\end{array}$ & $\begin{array}{l}\text { onme } \\
\text { onerg } \\
\text { ces C }\end{array}$ & & & & & & $\begin{array}{l}\text { WEL } \\
\angle O C \\
D A T\end{array}$ & $\begin{array}{l}\text { No. } \frac{1141}{\text { WON: WAG } 11} \\
07-27-90\end{array}$ \\
\hline & MOI & TORII & ; WELL & $D E V E$ & $O P$ & $M E N$ & $P R C$ & FRES & \\
\hline & & & & & & ONE & WELL VOL & $M E=4$ & 0 GALLONS \\
\hline DATE & TME & $\begin{array}{l}\text { quenows } \\
\text { PUNeED }\end{array}$ & 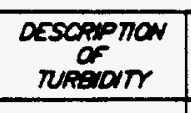 & $\begin{array}{l}\text { MEASUEED } \\
\text { MUREDTY } \\
\text { (NUIS) } \\
\end{array}$ & $\rho H$ & $\begin{array}{l}\text { convouc- } \\
\text { Nurr } \\
(\mu s /(\mathrm{cm})\end{array}$ & 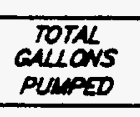 & $\begin{array}{l}\text { meIt } \\
\text { valumes } \\
\text { punfed }\end{array}$ & COMMENTS \\
\hline $07-27-90$ & 0930 & 160 & Clear. & 4.0 & 9.1 & 369 & 160 & 4.0 & \\
\hline & & & & & & & & & \\
\hline & & & & & & & & & \\
\hline & & & & & & & & & \\
\hline & & & & & & & & & \\
\hline & & & & & & & & & \\
\hline & & & & & & & & & \\
\hline & & & & & & & & & \\
\hline & & & & & & & & & \\
\hline & & & & & & & & & \\
\hline & & & & & & & & & \\
\hline & & & & & & & & & \\
\hline & & & & & & & & & \\
\hline & & & & & & & & & \\
\hline & & & & & & & & & \\
\hline & & & & & & & & & \\
\hline & & & & & & & & & \\
\hline $\begin{array}{l}\text { RESULTS } \\
\text { of DEVELC }\end{array}$ & $\begin{array}{l}\text { TEEN } \\
\text { PMENT }\end{array}$ & & Clear & 4.0 & 9.1 & 369 & 160 & 4.0 & \\
\hline
\end{tabular}

COMMENTS Fast recharger and good producer. Water remained clear even after surging. Passed with 4.0 NTU's. 
ERC / EDGE

Environmental

and Energy

WELL NO.1141

\section{HYDRAULIC CONDUCTIVTY CALCULATIONS}

PROGRAM SLUGT, VERSION 4.1, NOV. 1986

THIS PROGRAM CALCULATES MEAN TRANSMISSIVITIES FROM

SLUG-TEST DATA BASED ON TWO ANALYTICAL APPROACHES:

(1) METHOD OF COOPER, BREDEHOEFT AND PAPADOPULOS, 1967

(ARTICLE IN VOL.3, NO.1 OF WRR ENTITLED

"RESPONSE OF A FINITE DIAMETER WELL TO AN INSTANTANEOUS CHARGE OF WATER")

(2) METHOD OF BOUWER AND RICE, 1976 (ARTICLE IN

VOL. 12, NO.3 OF WRR ENTITLED

"A SLUG TEST FOR DETERMINING HYDRAULIC CONDUCTIVITY

OF UNCONFINED AQUIFERS WITH COMPLETELY OR PARTIALLY PENETRATING WELLS")

WELL NO.: 1141

DATE OF TEST: $9-19-90$

PROJECT NO.: E221-002

CLIENT: MMES

SITE LOCATION: WAG-11

EDGE, INC. FIELD INVESTIGATOR: JAMES W. CARUTHERS

\section{INPUT DATA ARE:}

INNER CASING DIAMETER $=4.00$ INCHES

INNER SCREEN OR OPEN-HOLE DIAMETER $=4.00$ INCHES

DIAMETER OF DRILLED HOLE $=8.00$ INCHES

LENGTH OF SCREEN OR INTAKE PORTION $=15.00$ FEET

DEPTH FROM STATIC LEVEL TO BOTTOM OF SCREEN $=37.80$ FEET

THICKNESS OF SATURATED AQUIFER ZONE $=15.00$ FEET

DEPTH TO STATIC WATER LEVEL BELOW REF. POINT $=1.00$ FEET

ESTIMATED POROSITY OF GRAVEL PACK $=.20$

FALLING-HEAD INDEX $=1$ ("1" IF FALLING,"0" IF RISING)

NUMBER OF DEPTH-TIME DATA POINTS = 32

HO WAS COMPUTED FROM INTERCEPT OF PLOT OF LOG(H) VS. TIME

SUCCESSIVE COMPUTED

VALUES FOR HO

(FEET)

3.3405

3.3258

PAGE 17 OF 22. 
ERC / EDGE

Environmental

WELL No. 1141

\section{HYDRAULIC CONDUCTIVTY CALCULATIONS}

\begin{tabular}{|c|c|c|}
\hline$\left(\right.$ SEC $\left.^{\text {TIME }}\right)$ & $\begin{array}{l}\text { DEPTH TO WATER } \\
\text { (FEET) }\end{array}$ & $\begin{array}{l}\text { HEAD } \\
\text { (FEET) }\end{array}$ \\
\hline $\begin{array}{r}10.00 \\
20.00 \\
30.00 \\
40.00 \\
50.00 \\
60.00 \\
75.00 \\
90.00 \\
105.00 \\
120.00 \\
150.00 \\
180.00 \\
240.00 \\
300.00 \\
360.00 \\
420.00 \\
480.00\end{array}$ & $\begin{array}{l}4.130 \\
4.140 \\
4.120 \\
4.080 \\
4.070 \\
4.040 \\
3.970 \\
3.940 \\
3.880 \\
3.810 \\
3.700 \\
3.600 \\
3.370 \\
3.170 \\
2.980 \\
2.810 \\
2.640\end{array}$ & $\begin{array}{l}3.130 \\
3.140 \\
3.120 \\
3.080 \\
3.070 \\
3.040 \\
2.970 \\
2.940 \\
2.880 \\
2.810 \\
2.700 \\
2.600 \\
2.370 \\
2.170 \\
1.980 \\
1.810 \\
1.640\end{array}$ \\
\hline $\begin{array}{r}540.00 \\
600.00 \\
720.00 \\
840.00 \\
960.00 \\
1080.00 \\
1200.00 \\
1320.00 \\
1440.00 \\
1560.00 \\
1680.00 \\
1800.00 \\
1920.00 \\
2040.00 \\
2160.00\end{array}$ & $\begin{array}{l}2.500 \\
2.360 \\
2.120 \\
1.950 \\
1.800 \\
1.670 \\
1.570 \\
1.490 \\
1.420 \\
1.320 \\
1.270 \\
1.210 \\
1.190 \\
1.170 \\
1.120\end{array}$ & $\begin{array}{r}1.500 \\
1.360 \\
1.120 \\
.950 \\
.800 \\
.670 \\
.570 \\
.490 \\
.420 \\
.320 \\
.270 \\
.210 \\
.190 \\
.170 \\
.120\end{array}$ \\
\hline
\end{tabular}


ERC / EDGE

Environmental

and Energy

WELL NO. 1141

Services Co.

\title{
HYORAULIC CONDUCTIVTY CALCULATIONS
}

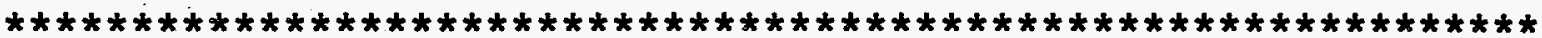
METHOD OF BOUWER AND RICE

COMPUTED RESULTS USING DIAMETER OF DRILLED HOLE:

PERMEABILITY $=4.75 \mathrm{E}-06 \mathrm{FT} / \mathrm{SEC}=1.45 \mathrm{E}-04 \mathrm{CM} / \mathrm{SEC}$

TRANSMISSIVITY $=7.13 \mathrm{E}-05 \quad \mathrm{FT} * * 2 / \mathrm{SEC}$
\end{abstract}

COMPUTED RESULTS USING DIAMETER OF CASING AND SCREEN:

PERMEABILITY $=5.57 \mathrm{E}-06 \mathrm{FT} / \mathrm{SEC}=1.70 \mathrm{E}-04 \mathrm{CM} / \mathrm{SEC}$

TRANSMISSIVITY $=8.36 \mathrm{E}-05 \mathrm{FT} * 2 / \mathrm{SEC}$ 


\section{ERCE}

Environmental

and Energy

WELL No. 1141

Services Co.

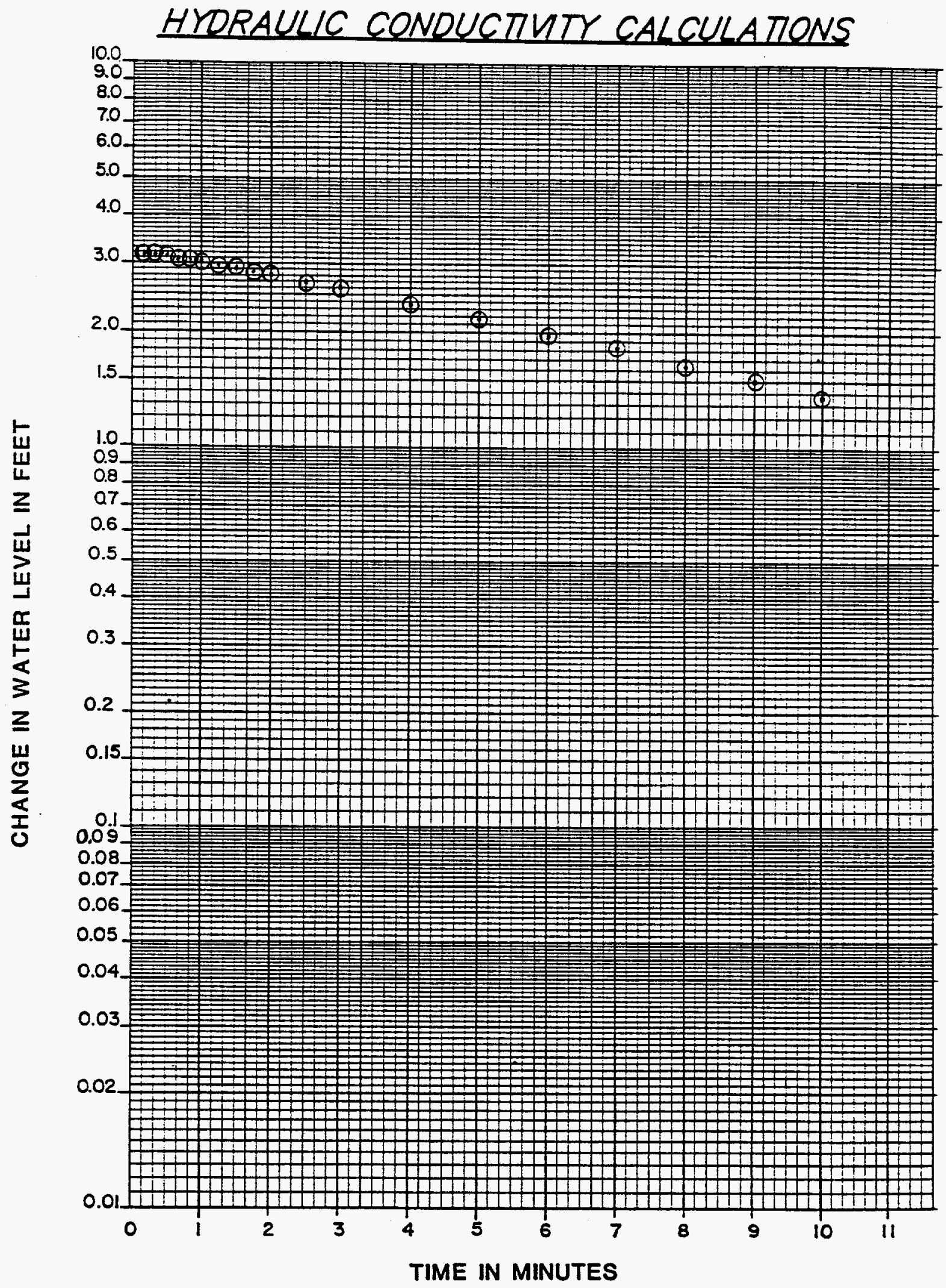




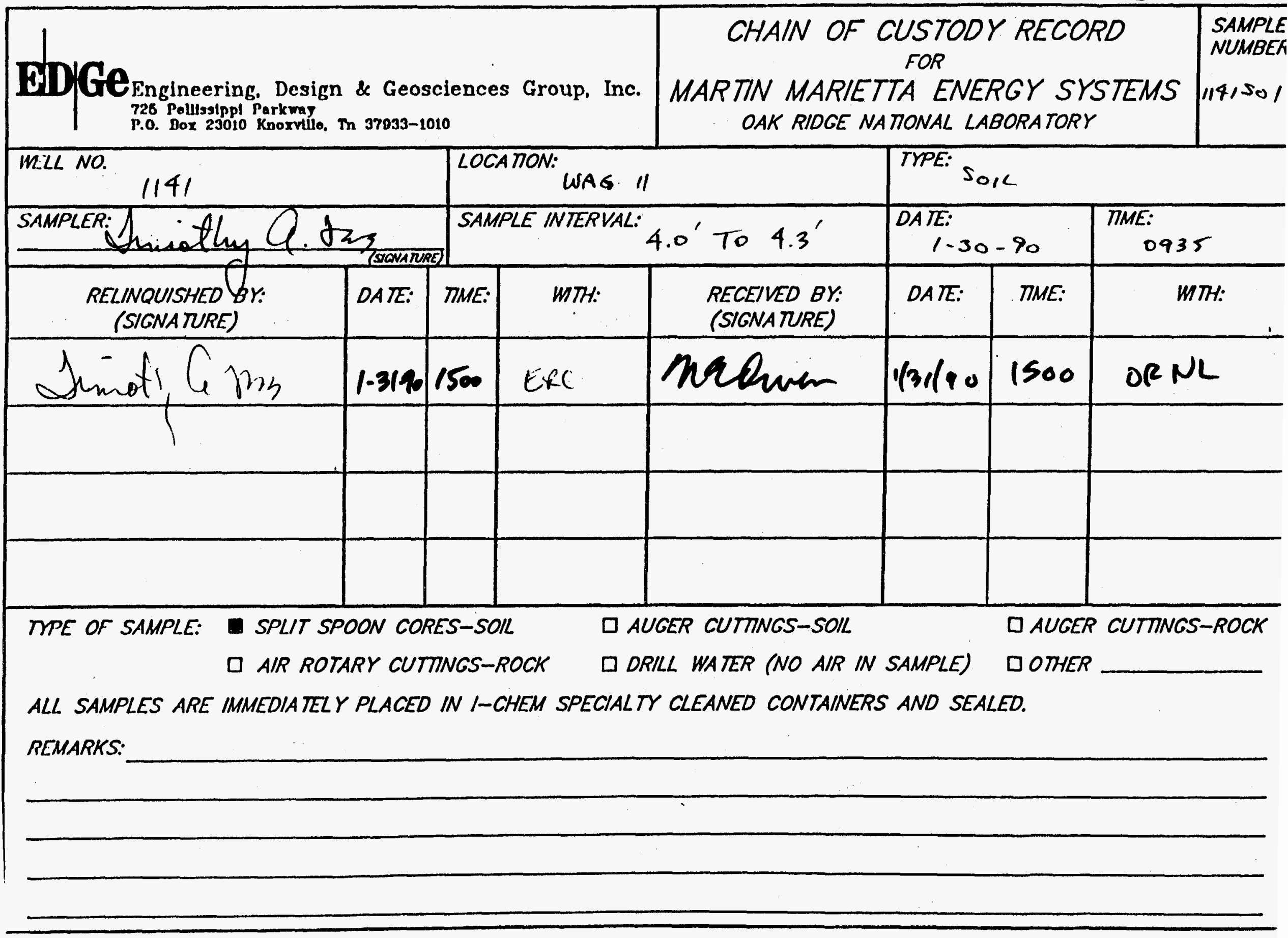




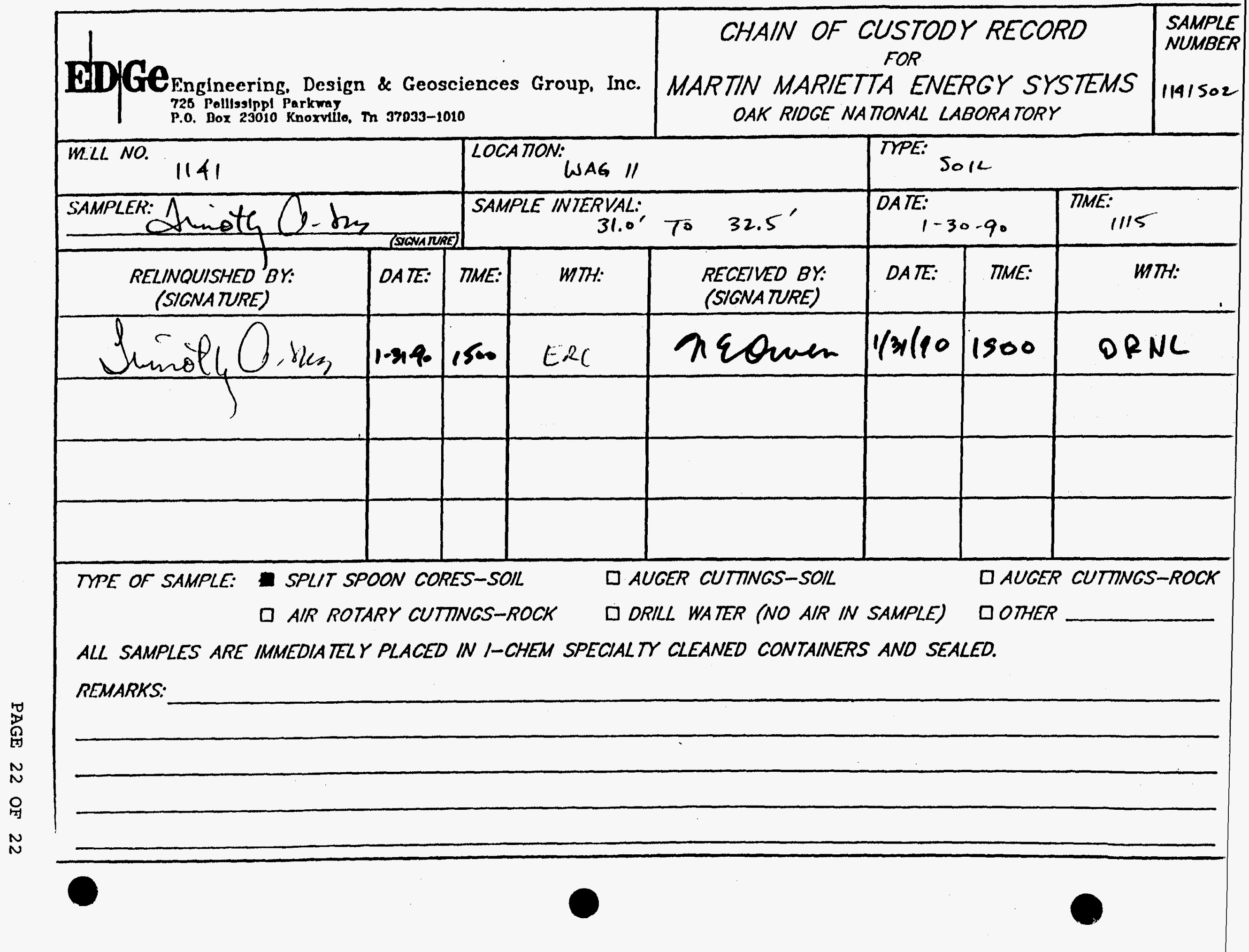


ERC / EDGE

Environmental

and Energy

Services Co.

1.0 General Information

\subsection{Well Location}

Monitoring well number 1143 is located in WAG 11. It is located in the southern boundary of "White wing scrap Yard" or WAG 11. The location is shown on ORNL drawing number C3E20004A075. Survey coordinates for this well are $\mathrm{N} 35,068.4127, \mathrm{E} 27,569.5606$ (X-10 grid) or latitude $35^{\circ}-57^{\prime}-03.88^{\prime \prime}$ and longitude $84^{\circ}-21^{\prime}-04.16^{\prime \prime}$. Coordinate data were provided by Martin Marietta Energy systems. The method used for conversion from $x-10$ grid to Tennessee-Lambert state Plane coordinates came from the publication "Tennessee Valley Authority Data Services Branch and Mapping Services Branch, Oak Ridge, Tennessee, DOE Plant Control, November 6, 1985, Field Book: ESS-3115, pp. 1-20." The latitude and longitude were calculated by Adams craft Herz walker Engineering, Inc., using methods from the U.S. Coast and Geodetic survey Publication 62-4, "State Plane Coordinates by Automatic Data Processing."

\subsection{Driling Information}

Well number 1143 was drilled by Geotek Engineering Company. An Ingersoll Rand T-4 rig was used to drill this boring for monitor well installation under operation of Larry Ledbetter with the assistance of Fred Dixon. Drilling commenced on 1-23-90 and was finished on 3-6-90. Paragraph 2.4.1 includes a detailed discussion of the well installation and a well schematic is included on the well installation/completion form. A synopsis of the 
drilling activity follows. This information was typed directly from field notes and was edited only when necessary for clarification.

1-23-90 The rig was mobilized to the staked location and set up on plastic sheeting. The boring was augered to 6.5 feet using a 22-inch auger. Set 6.5 feet of $151 / 4$-inch decontaminated steel diverter casing and grouted it to surface.

1-24-90 Augered from 6.5 feet to refusal at 27.5 feet using a 14.0-inch auger. Rig up a 14.0-inch air rotary tricone and drill from 27.5 feet to 30.0 feet.

1-25-90 Set 30.0 feet 10 1/4-inch decontaminated steel surface casing with bentonite seal and tremie grouted it to surface with 15 sacks grout.

2-1-90 Rig up and drill from 30.0 feet to 38.0 feet using an 8.0-inch air rotary tricone bit.

2-2-90 Drill from 38.0 feet to total depth at 52.5 feet. Rig down.

3-6-90 Set 4-inch stainless steel well casing and screens with sandpack and bentonite seal. 3-7-90 Tremie grouted well casing annulus with 9.0 sacks of cement.

This well was logged by ERC Environmental and Energy Services Co., Inc., hydrogeologists Bruce Mcmaster and Timothy A. Lee. All well construction materials and supplies were from Martin Marietta Energy Systems approved batches. The batch origin of individual items is shown on the included Monitoring Well Materials Certification form. 
ERC / EDGE

Environmental

and Energy

Services Co.

\subsection{Technical Information}

\subsection{Decontamination Procedures}

The drilling rig, down hole tools, surface casing, stainless steel screen, stainless steel casing, centralizers, and stainless steel silt trap underwent the cleaning decontamination procedures outlined in the drilling specifications (Release specific Technical Directions for Regulatory Compliance Monitoring Wells Phase 1, Oak Ridge National Laboratory, Oak Ridge, W.O., K-4147, April 1987, pgs, 2-4). A checklist of the cleaned materials is included with this data package.

\subsection{Geology}

The northeastern half of WAG 11 is underlain by Chickamauga Limestone. The Rome Formation underlies the southwestern half of WAG 11. The Chickamauga Limestone is brought into contact with the Rome Formation by the White Oak Mountain thrust fault, the trace of which bisects WAG 11 from northwest to southeast. The lowermost beds of the Chickamauga are composed of thin bentonitic beds, gray clay shale, and maroon to gray calcareous siltstone. The majority of the Chickamauga, approximately 1,500' thick, is a dominantly gray, dense, finely crystalline, thin bedded limestone with varying amounts of chert. The uppermost beds consist of yellow and maroon calcareous siltstone and blue-gray limestone. The Rome Formation is composed of interbedded sandstone, siltstone, shale and locally, dolomite. 


\section{3 sample collection}

No soil or water samples were collected during drilling.

The Ingersoll Rand T-4 compressed air was sampled with a cloth filter inserted between drill rods on 2-2-90. The sample was examined with an ultraviolet light for the presence of hydrocarbons. The filter showed no detectable signs of hydrocarbons.

\subsection{Installation and Development}

\subsubsection{Installation}

This was a Type B well. A 22.0-inch diameter boring was augered from ground surface to 6.5 feet. A 15 1/4-inch diverter casing was installed from surface to 6.5 feet below ground surface and grouted in place. A 14.5-inch diameter boring was augered from 6.5 feet to 27.5 feet (auger refusal). The boring was then extended past the refusal depth with a 14.0 -inch air rotary tricone roller bit from 27.5 feet to 30.0 feet. A 10 3/4-inch diameter string of decontaminated steel surface casing was installed from 0.0 feet to 30.0 feet, sealed with a 1.5 foot bentonite pellet layer from 28.5 feet to 30.0 feet, and tremie grouted in place. The surface casing minimizes potential cross contamination between the regolith and bedrock water bearing zones. After the surface casing was installed, the air rotary method was used to drill an 8-inch diameter boring to a total depth of 52.5 feet. A 4-inch diameter stainless steel screen with threaded bottom cap was installed from 37.5 feet to 52.5 feet. A 4-inch diameter stainless steel casing was installed from the top of the screen at 37.5 feet and 
extended 2.5 feet above ground surface. A sandpack was then tremied into the annular space from 30.4 to 52.5 feet, with a 3.6 foot bentonite pellet seal poured into the annular space above the sandpack from 26.8 to 30.4 feet. The annular space from the top of the bentonite seal to the surface was tremie grouted with a cement/bentonite slurry. A detailed schematic of the well is included on the well installation/completion form.

\subsubsection{We11 Development}

Well number 1143 was developed to remove drill cuttings, silt, and other fines. The monitoring was developed using a Geoguard pump with an air compressor. All pumps were cleaned prior to use according to specified cleaning procedures (see Paragraph 2.1). The well was developed until a measured total of 161 gallons of water had been evacuated and the clarity of the discharge water was approved by the company representative. The final turbidity value measured at completion was 4.0 NTU's. A development form showing the exact method of development and other pertinent data is appended.

\subsubsection{Installation of Dedicated Monitoring Well Pump}

After the well was developed, a Geoguard Model No. 5614 dedicated monitoring well pump was installed on $7 / 27 / 90$ at a depth of 51.5 feet below ground surface. These pumps are decontaminated at American sigma and are sent prepackaged. A copy of the pump certification is kept on file at ORNL. 


\subsection{Hydraulic conductivity Testing}

Well number 1143 was tested for the determination of hydraulic conductivity of the aquifer in the vicinity of the well screen. This was accomplished by instantaneously removing a known quantity of water from the monitoring well and measuring the recovery of the water level over time. The changing water levels were measured using a Druck 15 psi pressure transducer and an Omnidata Datapod II data recorder. The hydraulic conductivity value of $1.45 \times 10^{-4} \mathrm{~cm} / \mathrm{second}$ (shown as permeability on the hydraulic conductivity calculations printout attached) was calculated using the Bouwer and Rice method. A computer printout of the hydraulic conductivity calculations is included in this data package. 


\section{PRE-DRILLING CHECKLIST FOR MONITORING WELLS}

\section{PRE-DRILLING TASKS}

1. EXCAVTION PERMIT OBTAINED

2. ALL EQUIPMENT HAS BEEN CLEANED BEFORE DRILLING.

30. SCREEN AND CASING HAVE BEEN WASHED, STEAMED, RINSED WTH DE-IONIZED OR DISTILLED WATER, RINSED WTH ISOPROPY ALCOHOL, WRAPPED WTH PROTECTVE COVERING AND STORED OFF THE GROUND.

36. PRE-PACKAGED SCREENS, CASING AND CENTRALIZERS WERE USED.

4. WORK AREA FOR SAMPLE EXAMINATION COVERED WTH CLEAN POL YETHRENE.

5. CLEAN KNIVES, GLOVES, SAMPLE JARS AND LABELS ON HAND.

6. POL YETHRENE COVER IN PLACE OVER HOLE.

7. AIR ROTARY COMPRESSED AIR SAMPLED.

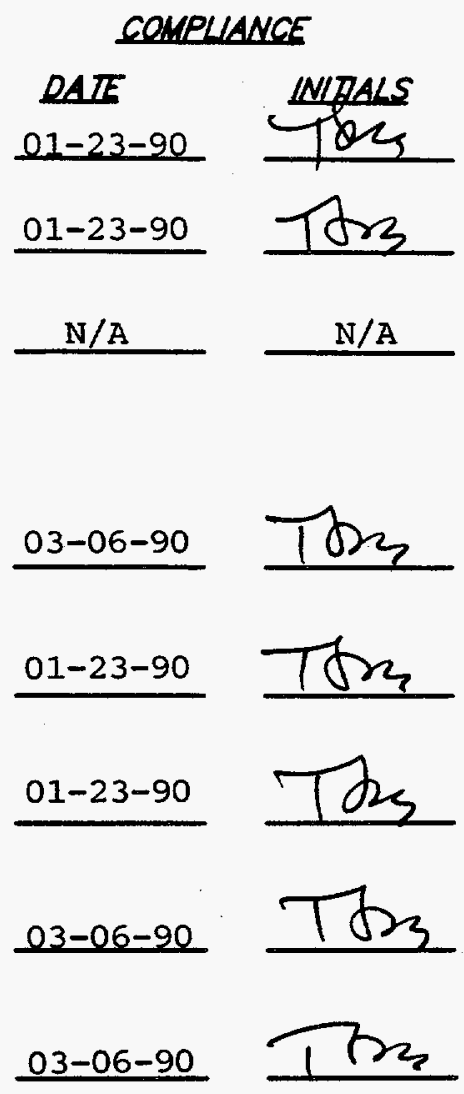

COMPLIANCE

RESUL IS: No hydrocarbons detected under ultraviolet light.

ADDITIONAL NOTES/OBSERVATONS:

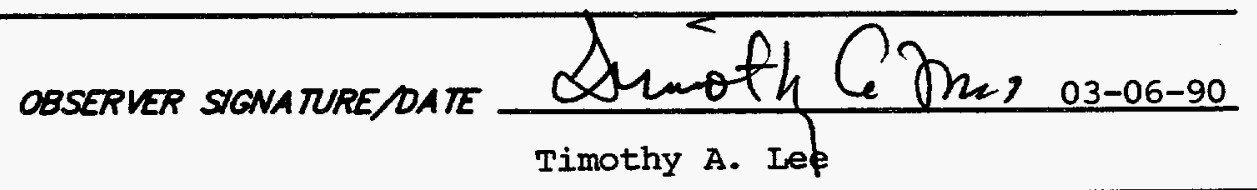

PAGE 7 of 19. 
ERC / EDGE

Environmental

and Energy

Services Co.

$\frac{\text { DECONTAMINATION CHECKLIST }}{\text { DRILLING EQUIPMENT }}$

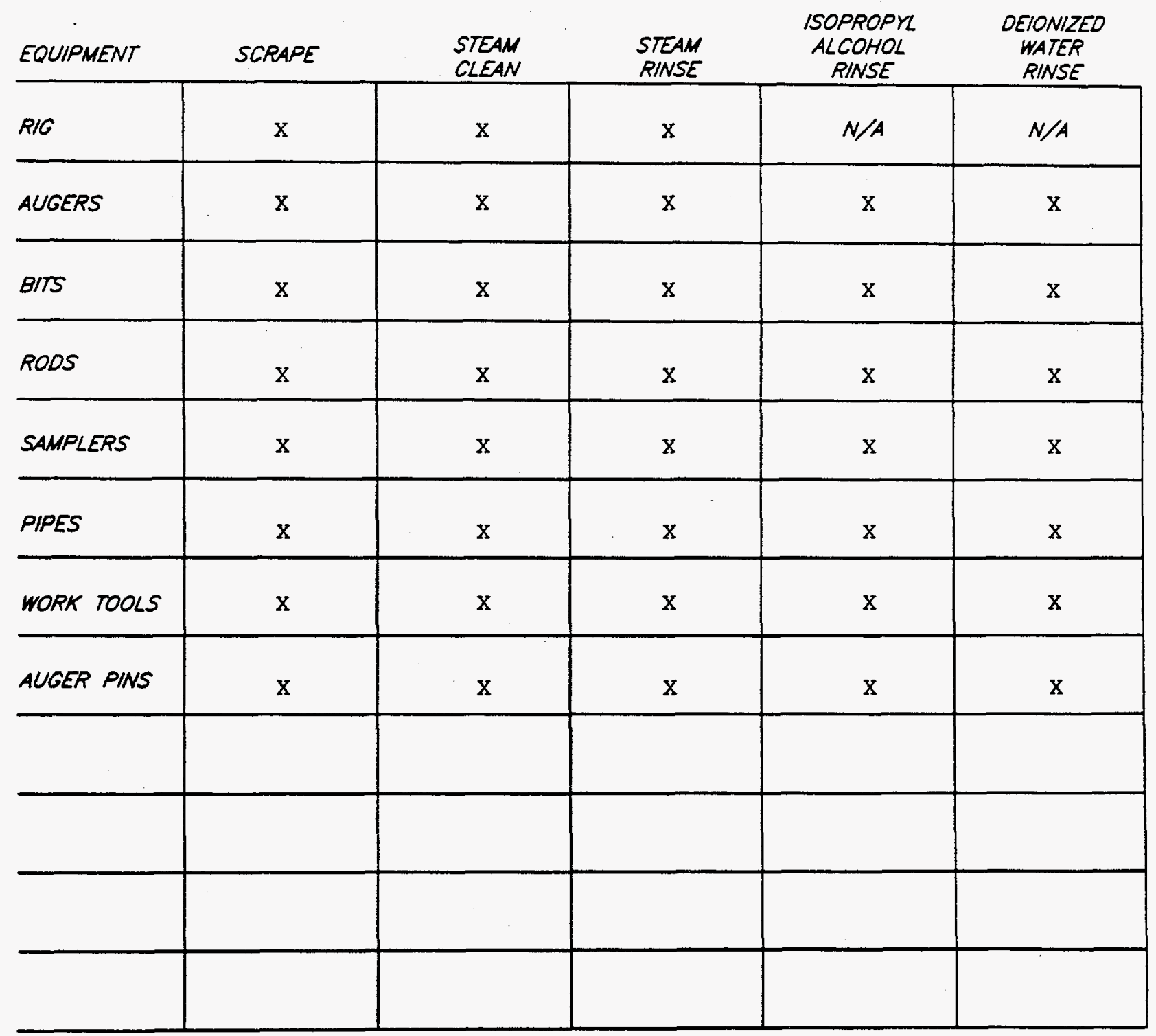

obserVER SIGNATURE/DATE Shmothe.bhs 03-06-90 Timothy A. Lele 
ORNL MONITORING WELL LOG

LOCA MON: WAG 11

ORILLER: Larry Ledbetter

HELPER: Fred Dixon

ORIL: Ingersol Rand T-4

TYPE ORILNG: Auger, Air Rotary

No. SAMPLES TAKEN: None

CONTANMEN MPE: Plastic, pan

THIXNESS OF SOL (RETUSAL DEPTH): 27.5

DEPTH DRILLO IN ROCK: 25.0

TOTAL DEPTH OF MEL: 52.5

\section{PAQE 1 of 2}

DATE: START: 01-23-90

FINISH: $03-06-90$

LOGCED BY. Timothy A. Lee

HEAL TH PHYSICST: N/A

LUBRICANT MPE:Green Stuff

MPE: N/A

\begin{tabular}{|c|c|c|c|c|}
\hline \multicolumn{2}{|c|}{$\begin{array}{l}\text { OEPTH } \\
\text { (FEED) }\end{array}$} & $\begin{array}{l}\text { SAMPLE } \\
\text { (NUMEZR } \\
\text { NTERVAL) }\end{array}$ & $\begin{array}{c}\text { PEERCENT } \\
\text { RECOVER } \\
\text { (SPUT SPOONS) }\end{array}$ & 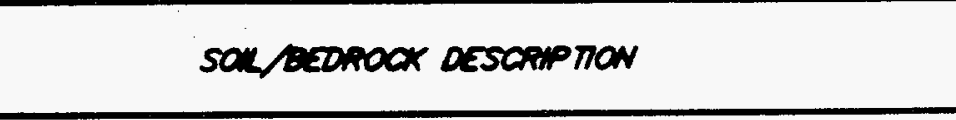 \\
\hline 0.0 & 3.0 & & Augered & Gravel fill. \\
\hline \multirow[t]{2}{*}{3.0} & 6.0 & & Augered & Clay, moderate brown, with minor light brown \\
\hline & & & & siltstone fragments, some dark organic, dry. \\
\hline \multirow[t]{2}{*}{6.0} & 10.0 & & Augered & Clay, dry, moderate yellowish brown, silty; \\
\hline & & & & minor fragments of siltstone, maroon. \\
\hline \multirow[t]{2}{*}{10.0} & 11.0 & & Augered & Shale and siltstone, dry, grayish to red, \\
\hline & & & & with minor $\tan$ silty lenses. \\
\hline \multirow[t]{3}{*}{11.0} & 15.0 & & Augered & Clay, wet, dark yellowish orange to pale \\
\hline & & & & orange, scattered shales, pale brown to light \\
\hline & & & & olive gray. \\
\hline \multirow[t]{2}{*}{15.0} & 20.0 & & Augered & Shales and siltstone, pale brown to maroon, \\
\hline & & & & damp, scattered greenish yellow clays. \\
\hline \multirow[t]{3}{*}{20.0} & 25.0 & & Augered & Siltstone, pale olive to grayish brown, \\
\hline & & & & scattered fragments of sandstone, yellowish \\
\hline & & & & gray medium grained, damp. \\
\hline \multirow[t]{3}{*}{25.0} & 30.0 & & Augered & Siltstone, pale olive to grayish brown, \\
\hline & & & & scattered fragments of sandstone, medium \\
\hline & & & & grained. \\
\hline \multirow[t]{3}{*}{30.0} & 35.0 & & Air Rotary & Siltstone, light olive and moderate brown, \\
\hline & & & & moderate crumbly, dry. \\
\hline & & & & \\
\hline
\end{tabular}

PACE 9 or 19. 


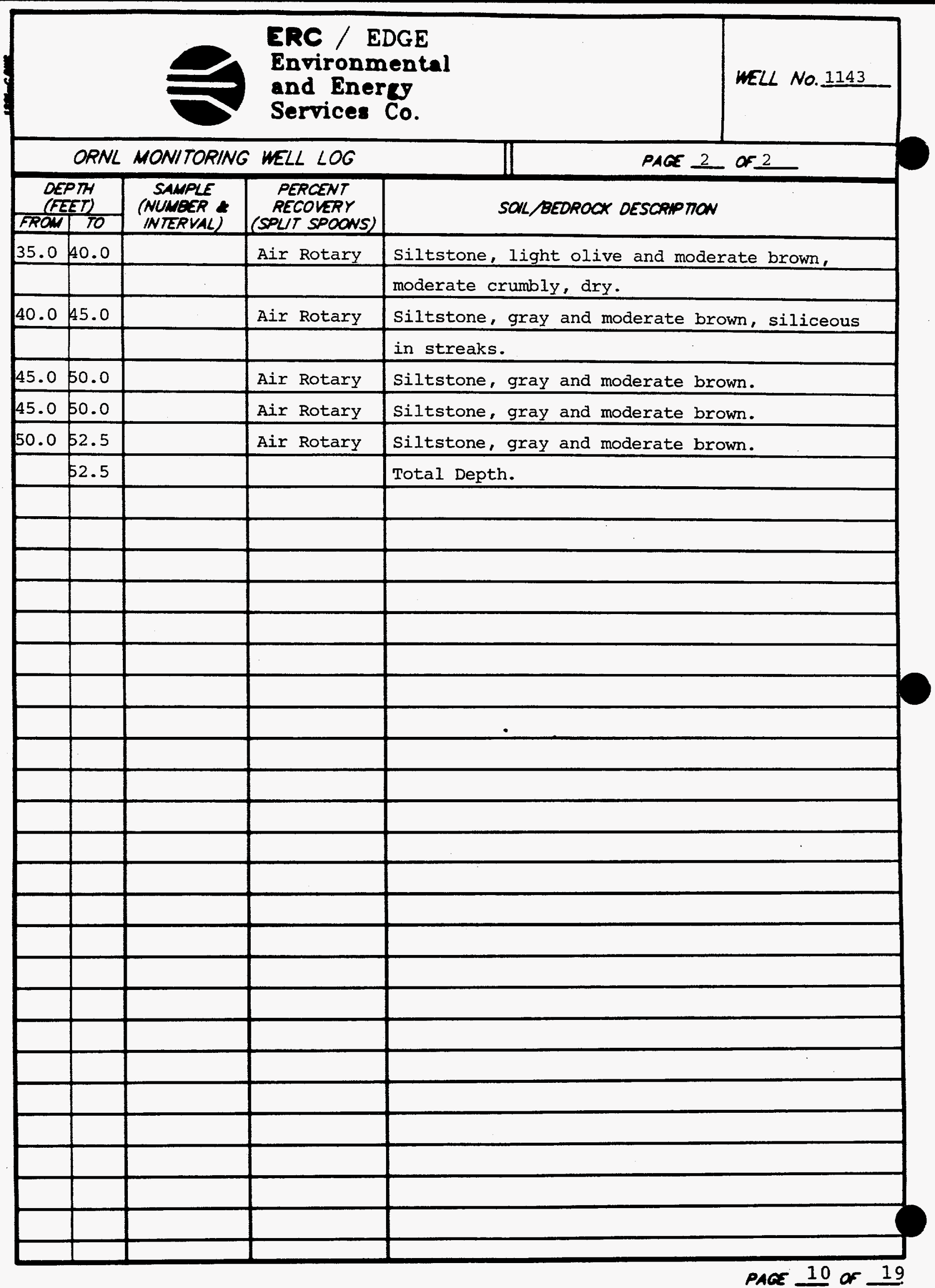




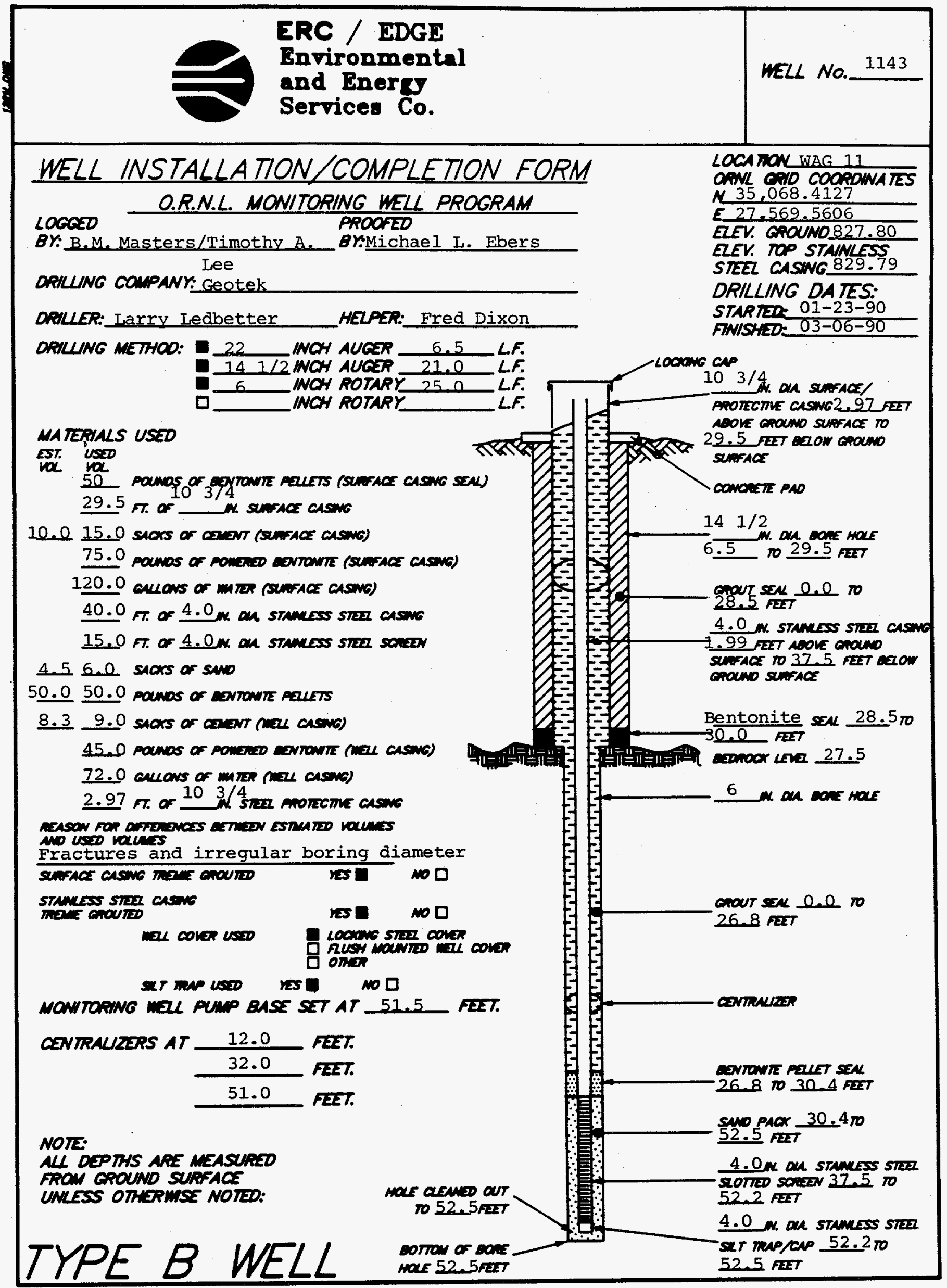

PACE 11 of 19 


\section{ERC / EDGE}

Environmental

WELL NO. 1143

and Energy

Services Co.

DATE: $03-06-90$

\section{MONITORING WELL MATERIALS \\ CERTIFICATION}

ITEM/MA TERIAL

DATE USED BATCH NUMBER

SANO

BENTONITE

STAINLESS STEEL SCREEN

STAINLESS STEEL CASING

(PREPACKAGED

STAINLESS STEEL CENTRALIZERS

STAINLESS STEEL CAPS

MONITORING WELL PUMP

GROUT Surface Casing

Well Casing

WELL COVERS

SURFACE CASING

(PREPACKAGED

(PREPACKAGED

(PREPACKAGED

(PREPACKAGED

Pellets

Powder

03-06-90

3

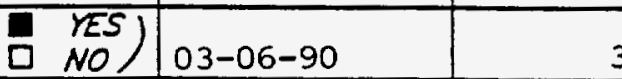

(rES)

口 NO $03-06-90$

D $\begin{gathered}\text { VES } \\ \text { NO }\end{gathered}$ 03-06-90

VES

03-06-90

2

口 NO

\begin{tabular}{l|l}
$03-06-90$ & 2 \\
\hline
\end{tabular}

2

NO)

\begin{tabular}{|l|l}
\hline $01-24-90$ & 6 \\
\hline $03-06-90$ & 6 \\
\hline & \\
\hline
\end{tabular}

$01-24-90$

4

COMMENTS:

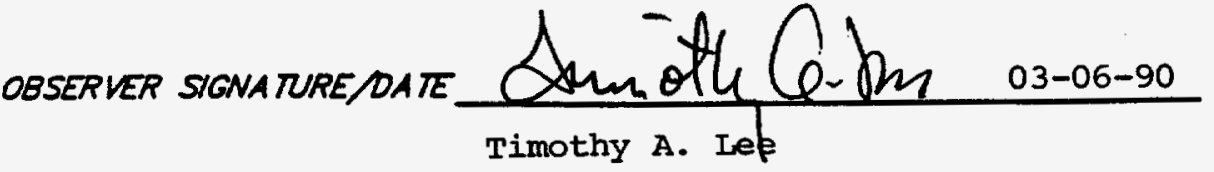


ERC / EDGE

Environmental

and Energy

WELL NO. 1143

Services Co.

\section{POST-MELL COMPLETION \\ CHECKLIST}

\section{POST-WELL COMPLETION TASKS}

$$
\begin{aligned}
& \text { COMPLIANCE } \\
& \text { DA.E WITALS }
\end{aligned}
$$

1. WUO SCRAPED FROW AUCERS SAMPLERS, AND ALL OTHER EOUIPWENT.

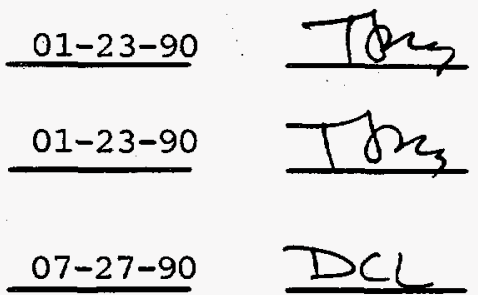

3. WEL OEVEORED IN ACCOROANCE WTH THE SPECITCA NON PROMOED ANO DETAKS OF THE DEVEZOPIEENT ACTUTH RECOROED.

4. ORKLNG STE PROPERL Y CLEAMED UP AFTER COMPLEION OF MEL INSTALU HON.

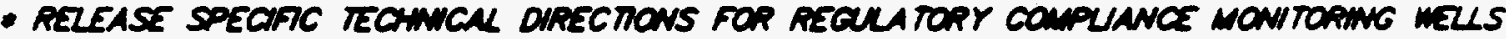
PHASE !, OAK RDDEE NATONAL LAOORATOPY, OAK RDOEE M.O. K-4147, APRK 1987.

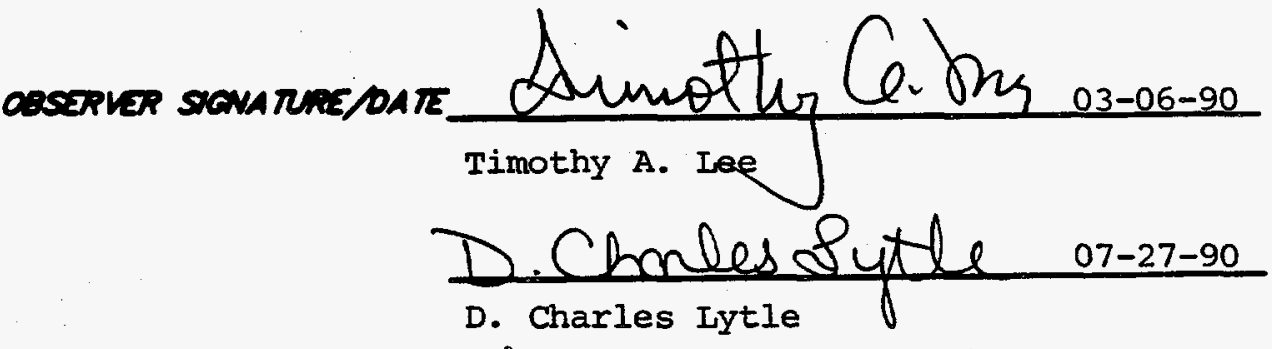




\section{MONITORING WELL \\ DEVELOPMENT FORM}

DEVELOPMENT DETAILS

METHOO OF

DEVEL OPMENT: Surging and Pumping

DEVELOPMENT

BEGAN DATE: $\quad 07-27-90$ TME:

DEVELOPMENT

ENDING DATE: $07-27-90$

DEVELOPMENT

OBSERVED BY: D. Charles Lytle

ONE WELL VOLUME: 34.7 GALLONS

TOTAL GALLONS PUMPED: 161 TOTAL WELL VOLUMES PUMPED: 4.6

INITAL PH: 8.8 FNAL PH: 8.8

INITAL CONOUCTUTH (KS/Cm): 409 FNAL CONDUCTUTH ( $\mu \mathrm{s} / \mathrm{cm}): 409$

DESCRIPTON OF INITAL TURBIOITY__Clear

DESCRIPTION OF FNAL TURBIDITY: Clear

FINAL MEASURED TURBIDITY: $4.0 \mathrm{NTU}$ 'S

WELL APPROVED BY:_R.C. Williams MMES

OOOR

OF MATER: None

WATER

DISCHARCED

TO:

GROUNO SURFACE

口 STORM SEMERS

D DRUMS

口 TANK IRUCK

STORACE TANKS

口 OTHER

INITAL PRE-DEVELOPNENT

WATER DEPTH: 24.8 feet from ground surface.

DEVELOPMENT OBSERVA TONS

OESERVER SIGNATURE PATE D. Chanles Sytleq-27-90

PAGE 14 of 19 


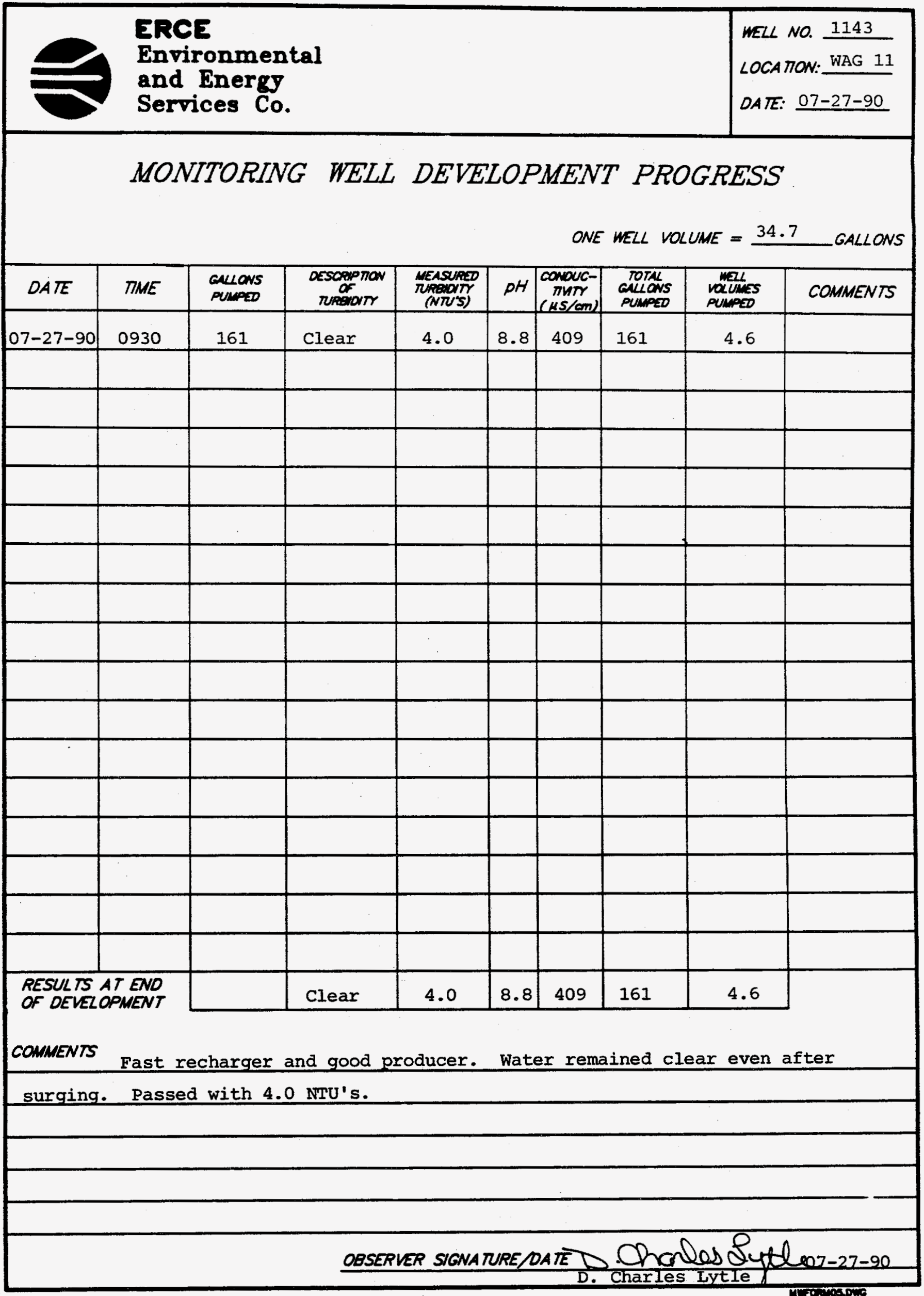


ERC / EDGE

Environmental

and Energy

WELL NO. 1143

Services Co.

\section{HYDRAULIC CONDUCTIVTY CALCULATIONS}

PROGRAM SLUGT, VERSION 4.1, NOV. 1986

\section{THIS PROGRAM CALCULATES MEAN TRANSMISSIVITIES FROM}

SLUG-TEST DATA BASED ON TWO ANALYTICAL APPROACHES:

(1) METHOD OF COOPER, BREDEHOEFT AND PAPADOPULOS, 1967

(ARTICLE IN VOL. 3, NO.1 OF WRR ENTITLED

"RESPONSE OF A FINITE DIAMETER WELL TO AN INSTANTANEOUS

CHARGE OF WATER")

(2) METHOD OF BOUWER AND RICE, 1976 (ARTICLE IN

VOL. 12, NO.3 OF WRR ENTITLED

"A SLUG TEST FOR DETERMINING HYDRAULIC CONDUCTIVITY

OF UNCONFINED AQUIFERS WITH COMPLETELY OR PARTIALLY PENETRATING WELLS")

WELI NO.: 1143

PROJECT NO.: E221-002

SITE LOCATION: WAG-11

\section{INPUT DATA ARE:}

INNER CASING DIAMETER $=4.00$ INCHES

INNER SCREEN OR OPEN-HOLE DIAMETER $=4.00$ INCHES

DIAMETER OF DRILLED HOLE $=6.00$ INCHES

LENGTH OF SCREEN OR INTAKE PORTION $=14.70$ FEET

DEPTH FROM STATIC LEVEL TO BOTTOM OF SCREEN $=23.30$ FEET

THICKNESS OF SATURATED AQUIFER ZONE $=14.70$ FEET

DEPTH TO STATIC WATER LEVEL BELOW REF. POINT $=8.80$ FEET

ESTIMATED POROSITY OF GRAVEL PACK $=.20$

FALLING-HEAD INDEX $=0$ ("1" IF FALLING, "O" IF RISING)

NUMBER OF DEPTH-TIME DATA PQINTS = 32

HO WAS COMPUTED FROM INTERCEPT OF PLOT OF LOG(H) VS. TIME

SUCCESSIVE COMPUTED

VALUES FOR HO

(FEET)

1.6552

1.6374 


\section{HYDRAULIC CONDUCTIVTY CALCULATIONS}

\begin{tabular}{|c|c|c|}
\hline$\left(\operatorname{SEC}^{\text {TIME }}\right)$ & $\begin{array}{l}\text { DEPTH TO WATER } \\
\text { (FEET) }\end{array}$ & $\begin{array}{l}\text { HEAD } \\
\text { (FEET) }\end{array}$ \\
\hline $\begin{array}{r}10.00 \\
20.00 \\
30.00 \\
40.00 \\
50.00 \\
60.00 \\
75.00 \\
90.00 \\
105.00 \\
120.00 \\
150.00 \\
180.00 \\
240.00 \\
300.00 \\
360.00 \\
420.00 \\
480.00\end{array}$ & $\begin{array}{l}6.990 \\
7.040 \\
7.110 \\
7.160 \\
7.210 \\
7.240 \\
7.300 \\
7.340 \\
7.370 \\
7.430 \\
7.500 \\
7.560 \\
7.690 \\
7.810 \\
7.910 \\
7.980 \\
8.060\end{array}$ & $\begin{array}{r}1.810 \\
1.760 \\
1.690 \\
1.640 \\
1.590 \\
1.560 \\
1.500 \\
1.460 \\
1.430 \\
1.370 \\
1.300 \\
1.240 \\
1.110 \\
.990 \\
.890 \\
.820 \\
.740\end{array}$ \\
\hline $\begin{array}{r}540.00 \\
600.00 \\
720.00 \\
840.00 \\
960.00 \\
1080.00 \\
1200.00 \\
1320.00 \\
1440.00 \\
1560.00 \\
1680.00 \\
1800.00 \\
1920.00 \\
2040.00 \\
2160.00\end{array}$ & $\begin{array}{l}8.140 \\
8.190 \\
8.260 \\
8.350 \\
8.410 \\
8.460 \\
8.540 \\
8.560 \\
8.610 \\
8.640 \\
8.650 \\
8.680 \\
8.710 \\
8.710 \\
8.750\end{array}$ & $\begin{array}{l}.660 \\
.610 \\
.540 \\
.450 \\
.390 \\
.340 \\
.260 \\
.240 \\
.190 \\
.160 \\
.150 \\
.120 \\
.090 \\
.090 \\
.050\end{array}$ \\
\hline
\end{tabular}




\section{HYDRAULIC CONDUCTIVTY CALCULATIONS}

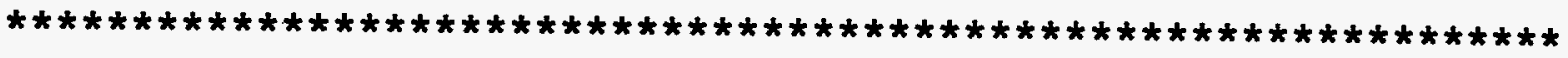

METHOD OF BOUWER AND RICE

COMPUTED RESULTS USING DIAMETER OF DRILLED HOLE:
PERMEABILITY $=4.77 \mathrm{E}-06 \mathrm{FT} / \mathrm{SEC}$
$=1.45 \mathrm{E}-04 \mathrm{CM} / \mathrm{SEC}$

TRANSMISSIVITY $=7.01 \mathrm{E}-05 \mathrm{FT} * * 2 / \mathrm{SEC}$
}

COMPUTED RESULTS USING DIAMETER OF CASING AND SCREEN:

$$
\text { PERMEABILITY }=5.25 \mathrm{E}-06 \mathrm{FT} / \mathrm{SEC}=1.60 \mathrm{E}-04 \mathrm{cM} / \mathrm{SEC}
$$

TRANSMISSIVITY $=7.71 \mathrm{E}-05 \mathrm{FT} * 2 / \mathrm{SEC}$ 
ERC / EDGE

Environmental

and Energy

WELL NO. 1143

Services Co.

\section{HYORAULIC CONDUCTIVTY CALCULATIONS}

10.0

8.0

7.0

6.0.

5.0

4.0

3.0

2.0

\section{5}

$+$

1 1900010

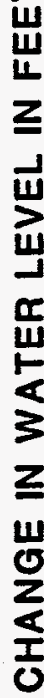

0.4

0.3

0.2

0.8

0.6

5

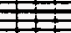

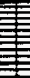

11

12

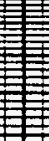

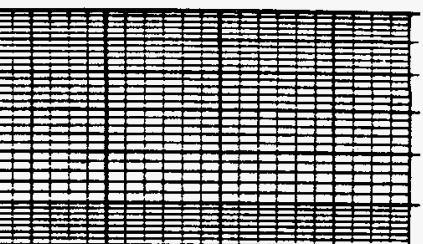

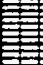

11

1 1

111

12

1

+2

+

111

1

$1+1$

121

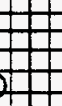

1

III

CII

0.1

0.08

0.06

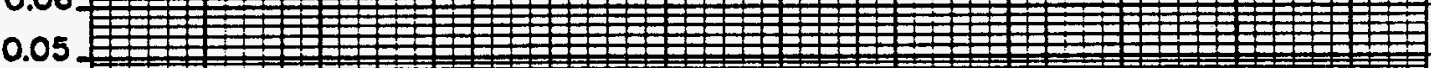

0.04

0.03

0.02

+

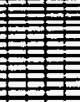

+

1

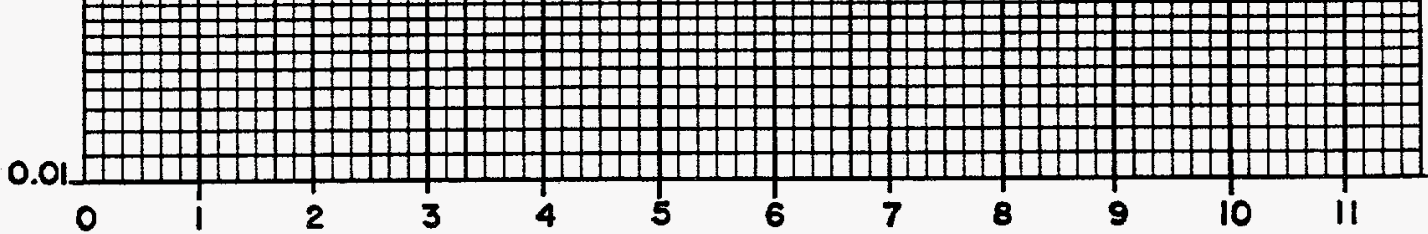

TIME IN MINUTES

PACE 19 of 19 
ERC / EDGE

Environmental

and Energy

Services Co.

1.0 General Information

\subsection{Well Location}

Monitoring well number 1144 is located in WAG 11 . It is located in the northwestern boundaries of "White wing Scrap Yard" or WAG 11. The location is shown on ORNL drawing number C3E20004A075. Survey coordinates for this well are $\mathrm{N} 35,339.3270, \mathrm{E} 27,421.6061$ (X-10 grid) or latitude $35^{\circ}-57^{\prime}-05.29^{\prime \prime}$ and longitude $84^{\circ}-21^{\prime}-07.49^{\prime \prime}$. Coordinate data were provided by Martin Marietta Energy systems. The method used for conversion from $\mathrm{x}-10 \mathrm{grid}$ to Tennessee-Lambert state Plane coordinates came from the publication "Tennessee Valley Authority Data Services Branch and Mapping Services Branch, Oak Ridge, Tennessee, DOE Plant Control, November 6, 1985, Field Book: ESS-3115, pp. 1-20." The latitude and longitude were calculated by Adams Craft Herz Walker Engineering, Inc., using methods from the U.S. Coast and Geodetic survey Publication 62-4, "state Plane coordinates by Automatic Data Processing."

\subsection{Drilling Information}

Well number 1144 was drilled by Geotek Engineering Company. An Ingersoll Rand T-4 rig was used to drill this boring for monitor well installation under operation of Larry Ledbetter with the assistance of Fred Dixon. Drilling commenced on 1-10-90 and was finished on 2-15-90. Paragraph 2.4.1 includes a detailed discussion of the well installation and a well schematic is included on the well installation/completion form. A synopsis of 
the drilling activity follows. This information was typed directly from field notes and was edited only when necessary for clarification.

1-10-90 The rig was mobilized to location and set up on plastic sheeting. Split spoon samples were taken from surface to refusal at 39.1 feet. The boring was reamed to 6.0 feet using a $22.0-$ inch auger.

1-11-90 Set and grouted 6.0 feet of 15.0-inch decontaminated steel diverter casing. Moved rig from hole

1-31-90 Moved rig back over hole. Drilled to 44.0 feet using a 14.0-inch air rotary tricone bit.

2-1-90 Set 44.0 feet of $103 / 4$-inch decontaminated steel surface casing. Moved rig from location.

2-2-90 Grouted surface casing with 15 sacks cement.

2-15-90 Move back to location. Drill from 44.0 to 122.5 feet using an 8.0-inch air rotary tricone bit. Run stainless steel 4 -inch well casing and screen and set with sand pack and bentonite seal.

2-16-90 Grouted well casing annulus with 13 sacks cement.

This well was logged by ERC Environmental and Energy Services Co., Inc., hydrogeologist Timothy A. Lee. All well construction materials and supplies were from Martin Marietta Energy Systems approved batches. The batch origin of individual items is shown on the included Monitoring Well Materials Certification form. 


\subsection{Technical Information}

\subsection{Decontamination Procedures}

The drilling rig, down hole tools, surface casing, stainless steel screen, stainless steel casing, centralizers, and stainless steel silt trap underwent the cleaning decontamination procedures outlined in the drilling specifications (Release specific Technical Directions for Regulatory Compliance Monitoring Wells Phase 1, Oak Ridge National Laboratory, Oak Ridge, W.O., K-4147, April 1987, pgs, 2-4). A checklist of the cleaned materials is included with this data package.

\subsection{Geology}

The northeastern half of WAG 11 is underlain by Chickamauga Limestone. The Rome Formation underlies the southwestern half of WAG 11. The Chickamauga Limestone is brought into contact with the Rome Formation by the White Oak Mountain thrust fault, the trace of which bisects WAG 11 from northwest to southeast. The lowermost beds of the chickamauga are composed of thin bentonitic beds, gray clay shale, and maroon to gray calcareous siltstone. The majority of the chickamauga, approximately 1,500' thick, is a dominantly gray, dense, finely crystalline, thin bedded limestone with varying amounts of chert. The uppermost beds consist of yellow and maroon calcareous siltstone and blue-gray limestone. The Rome Formation is composed of interbedded sandstone, siltstone, shale and locally, dolomite. 


\subsection{Sample collection}

One soil sample was collected during drilling, placed in an I-CHEM specialty cleaned glass container, sealed and submitted to sample Receiving, Analytical Chemistry Division, Bldg. 4500S, ORNL. A chain of custody form for this sample is included with this data package. Soil sample 1144S01, was collected in the split spoon interval from $29.8^{\prime}$ to $30.1^{\prime}$ on $1-10-90$.

A bulk density soil sample was collected from the split spoon sample interval from $6.5^{\prime}$ to $6.8^{\prime}$. The sample was measured, weighed and a bulk density of 2.04 grams $/ \mathrm{cm}^{3}$ was calculated.

The Ingersoll Rand T-4 compressed air was sampled with a cloth filter inserted between drill rods on 2-15-90. The sample was examined with an ultraviolet light for the presence of hydrocarbons. The filter showed no detectable signs of hydrocarbons.

\subsection{Installation and Development}

\subsubsection{Installation}

This was a Type B well. A 22.0-inch diameter boring was augered from ground surface to 6.0 feet. A $151 / 4$-inch diverter casing was installed from surface to 6.0 feet below ground surface and grouted in place. A 14.5-inch diameter boring was augered from 6.0 feet to 39.1 feet (auger refusal). The boring was then extended past the refusal depth with a 14.0-inch air rotary tricone roller bit from 39.1 feet to 44.0 feet. A 10 3/4-inch diameter string of decontaminated steel surface casing was 
installed from 0.0 feet to 44.0 feet, sealed with a 2.0 foot bentonite pellet layer from 42.0 feet to 44.0 feet, and tremie grouted in place. The surface casing minimizes potential cross contamination between the regolith and bedrock water bearing zones. After the surface casing was installed, the air rotary method was used to drill an 8-inch diameter boring to a total depth of 122.5 feet. A 4-inch diameter stainless steel screen with threaded bottom cap was installed from 102.1 feet to 122.3 feet. A 4-inch diameter stainless steel casing was installed from the top of the screen at 102.1 feet and extended 2.9 feet above ground surface. A sandpack was then tremied into the annular space from 98.5 to 122.3 feet, with a 1.4 foot bentonite pellet seal poured into the annular space above the sandpack from 97.1 to 98.5 feet. The annular space from the top of the bentonite seal to the surface was tremie grouted with a cement/bentonite slurry. A detailed schematic of the well is included on the well installation/completion form.

\subsubsection{Well Development}

Well number 1144 was developed to remove drill cuttings, silt, and other fines. The monitoring was developed using a Geoguard pump with an air compressor. All pumps were cleaned prior to use according to specified cleaning procedures (see Paragraph 2.1). The well was developed until a measured total of 970 gallons of water had been evacuated and the clarity of the discharge water was approved by the company representative. The final turbidity value measured at completion was 5 NTU's. A development form showing the exact method of development and other pertinent data is appended. 
ERC / EDGE

Environmental

and Energy

Services Co.

\subsubsection{Installation of Dedicated Monitoring Well Pump}

After the well was developed, a Geoguard Model No. 5614 dedicated monitoring well pump was installed on 9-16-90 at a depth of 119.6 feet below ground surface. These pumps are decontaminated at American Sigma and are sent prepackaged. A copy of the pump certification is kept on file at ORNL.

\subsection{Hydraulic Conductivity resting}

Well number 1144 was tested for the determination of hydraulic conductivity of the aquifer in the vicinity of the well screen. This was accomplished by instantaneously adding a known quantity of water to the monitoring well and measuring the recovery of the water level over time. The changing water levels were measured using a Druck 15 psi pressure transducer and an Omnidata Datapod II data recorder. The hydraulic conductivity value of $1.58 \times 10^{-6} \mathrm{~cm} / \mathrm{second}$ (shown as permeability on the hydraulic conductivity calculations printout attached) was calculated using the Bouwer and Rice method. A computer printout of the hydraulic conductivity calculations is included in this data package. 


\section{PRE-DRILLING CHECKLIST FOR MONITORING WELLS}

RRE-DRILUNG TASKS

1. EXCAVTION PERMIT OBTAINED

\begin{tabular}{|c|c|}
\hline \multicolumn{2}{|c|}{ COMPLIANCE } \\
\hline$D A T E$ & LNITALS \\
\hline $01-10-90$ & ME \\
\hline $01-10-90$ & ME \\
\hline $\mathrm{N} / \mathrm{A}$ & $\mathrm{N} / \mathrm{A}$ \\
\hline
\end{tabular}

30. SCREEN AND CASING HAVE BEEN WASHED, STEAMED, RINSED WTH DE-IONIZED OR DISTILED WATER, RINSED WTH ISOPROPK ALCOHOL, MRAPPED WTH PROTECTIV COVERING AND STORED OFF THE GROUND.

36. PRE-PACKAGED SCREENS, CASING AND CENTRALIZERS WERE USED.

4. WORK AREA FOR SAMPLE EXAMINATION COVERED WTH CLEAN POLYETHRENE.

5. CLEAN KNIVES, GLVES, SAMPLE JARS AND LABELS ON HAND.

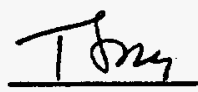

$01-10-90$

Me

6. POL YETHIRENE COVER IN PLACE OVER HOLE.

$01-10-90$ ME

7. AIR ROTARY COMPRESSED AIR SAMPLED.

RESUL TS: No hydrocarbons detected under ultraviolet light.

ADDITIONAL NOTES/OBSERVATIONS:

OBSERVER SIGNATURE DATE

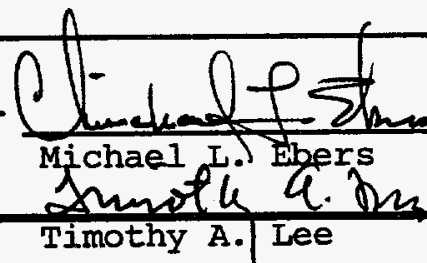

01-10-90 $02-15-90$ 
ERC / EDGE

Environmental

and Energy

$\frac{\text { DECONTAMINATION CHECKLIST }}{\text { DRILLING EQUIPMENT }}$

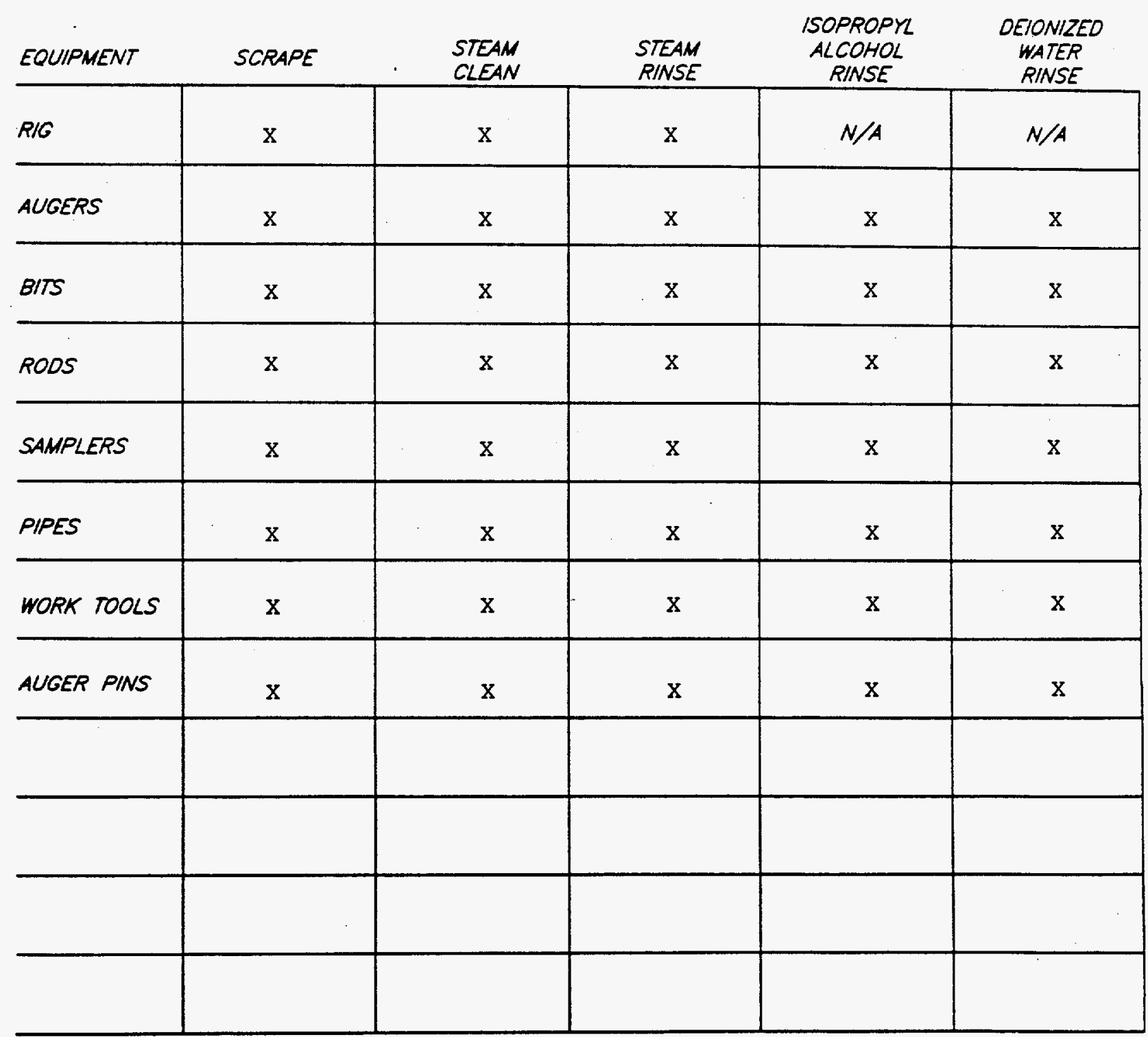

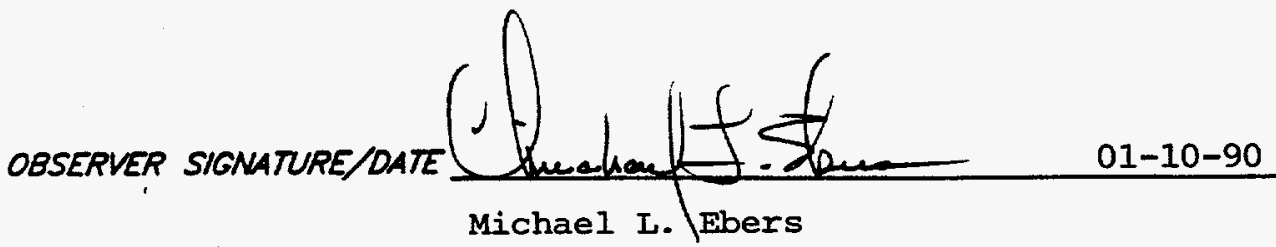

PAGE 8 OF 21. 
LOCA MON: WAG 11

ORILLER: Larry Ledbetter

HELPER: Fred Dixon

ORILL: Incersol Rand $\mathrm{T}-4$
DATE: START: 01-10-90

FINSH: 02-15-90

LOGGED Br:Michael Ebers/Timothy Lee HEALIH PHISOCST: CarI Stooksbury

TPE ORILLNG: Split Spoon, Auqer and Air Rotary LUBRGWT MPE: Green Stuff

No. SAMPLES TAKEN: One TrPE: Soil

CONTANMENT MPE: Auger Pan, Plastic

THIOKNESS OF SOK (REFUSM DEPTH): $\quad 39.1$

DEPTH DRLLED IN ROCK: 83.4

OAXUNG FZUD SAMPLES.

TOTAL OEPTH OF WEL: 1225

\begin{tabular}{|c|c|c|c|c|}
\hline $\begin{array}{r}05 \\
\frac{(F E}{7 \mathrm{Ray}^{y}}\end{array}$ & & $\begin{array}{l}\text { SAMPLE } \\
\text { (NUMEER } \\
\text { INTERVAS) }\end{array}$ & $\begin{array}{c}\text { PERCENT } \\
\text { AECOVERY } \\
\text { (SOUT SPOANS) }\end{array}$ & sak pespock asschiption \\
\hline 0.0 & 1.0 & & --- & Gravel pad \\
\hline 1.0 & 2.8 & & $100 \%$ & Clay, moderate reddish brown, loose to medium \\
\hline & & & & dense, slightly damp, medium stiff. \\
\hline 2.8 & 3.3 & & $100 \%$ & Clay, moderate reddish brown, with grayish \\
\hline & & & & orange speckles, damp. \\
\hline 3.3 & 5.0 & & $100 \%$ & Clay, reddish brown, grayish orange along \\
\hline & & & & relict jointing planes, blocky, crumbly, dry. \\
\hline 5.0 & 7.5 & & $100 \%$ & Clay, moderate reddish brown, with scattered \\
\hline & & & & small yellowish orange blocks of clay, damp, \\
\hline & & & & fine crumbly to medium dense, bulk density \\
\hline & & & & at $6.5^{\prime}-6.8^{\prime}$. Bulk density equals \\
\hline & & & & 2.04 grams $/ \mathrm{cm}^{3}$ \\
\hline 7.5 & 9.2 & & $100 \%$ & Clay, moderate reddish brown with blocks of \\
\hline & & & & grayish orange sandy clay, crumbly to medium \\
\hline & & & & dense, slightly damp. \\
\hline 9.2 & 9.8 & & $100 \%$ & Clay, moderate reddish brown, dense, stiff, \\
\hline & & & & plastic, slightly damp. \\
\hline 9.8 & 16.0 & & & Clay, moderate reddish brown, blocky, loose, \\
\hline & & & & crumbly, thin grayish orange zones, relict \\
\hline & & & & bedding and jointing visible. \\
\hline 16. & 17.0 & & 1008 & Clay, moderate reddish brown, crumbly, \\
\hline
\end{tabular}




\begin{tabular}{|c|c|c|c|c|}
\hline \multicolumn{5}{|c|}{$\begin{array}{l}\text { ERe / E } \\
\text { Environn } \\
\text { and Ener } \\
\text { Services }\end{array}$} \\
\hline \multicolumn{5}{|c|}{ ORNL MONITORING WELL LOG } \\
\hline \multicolumn{2}{|c|}{$\begin{array}{l}\text { OEPTH } \\
\text { (FEET) } \\
\end{array}$} & $\begin{array}{l}\text { SAMPLE } \\
\text { (NUMBER } \\
\text { INTERVAL) }\end{array}$ & $\begin{array}{c}\text { PERCENT } \\
\text { RECOVERY } \\
\text { (SPUT SPOONS) }\end{array}$ & SOL/BEDROCK DESCRIPTON \\
\hline & & & & slightly damp, very faint relict bedding-- \\
\hline & & & & "Ghost" bedding. \\
\hline 17.0 & 17.2 & & $100 \%$ & Clay, reddish brown, dense, stiff. \\
\hline \multirow[t]{2}{*}{17.2} & 18.2 & & $100 \%$ & Clay, reddish brown and grayish orange, and \\
\hline & & & & deeply weathered blocky shale. \\
\hline \multirow[t]{3}{*}{18.2} & 21.0 & & $100 \%$ & Clay, reddish brown with blotches and \\
\hline & & & & speckles of reddish orange and grayish \\
\hline & & & & yellow, crumbly. \\
\hline \multirow[t]{2}{*}{21.0} & 22.2 & & $100 \%$ & Clay, reddish brown, few thin streaks of \\
\hline & & & & brownish orange, very damp, soft, loose. \\
\hline \multirow[t]{2}{*}{22.2} & 23.0 & & $100 \%$ & Clay, pale olive and moderate yellow, very \\
\hline & & & & distinct color change, damp. \\
\hline \multirow[t]{5}{*}{23.0} & 27.0 & & $100 \%$ & Clay, banded with alternating colors of \\
\hline & & & & reddish brown, moderate yellow and light \\
\hline & & & & brown, damp, soft to stiff, crumbly to plastic, \\
\hline & & & & (reddish brown clay is crumbly, other colors \\
\hline & & & & are stiff and plastic). \\
\hline \multirow[t]{3}{*}{27.0} & 30.2 & $1144 S 01$ & $100 \%$ & Clay, moderate yellow, pale olive and reddish \\
\hline & & e $29.8-$ & & brown, blotchy, crumbly and stiff, damp. \\
\hline & & 30.1 & & \\
\hline \multirow[t]{4}{*}{30.2} & 39.1 & & $100 \%$ & Clay, moderate yellow, fine silty, relict \\
\hline & & & & thing laminations, $50^{\circ}$ to horizontal, damp, \\
\hline & & & & crumbly, free water in boring starting at $29^{\prime}$. \\
\hline & 39.1 & & & Split Spoon refusal and auger refusal. \\
\hline 39.1 & 44.0 & & Air Rotary & Siltstone, slightly shaley, olive gray. \\
\hline \multirow[t]{4}{*}{44.0} & 50.0 & & Air Rotary & Siltstone, slightly shaley, olive gray; \\
\hline & & & & scattered fragments of sandstone, medium \\
\hline & & & & grained, moderate yellowish brown, scattered \\
\hline & & & & fragments of grout. \\
\hline 50.0 & 55.0 & & Air Rotary & Siltstone, slightly shaley, olive gray. \\
\hline 55.0 & 60.0 & & Air Rotary & Siltstone, slightly shaley, olive gray. \\
\hline 60.0 & 65.0 & & Air Rotary & Siltstone, slightly shaley, olive gray. \\
\hline
\end{tabular}




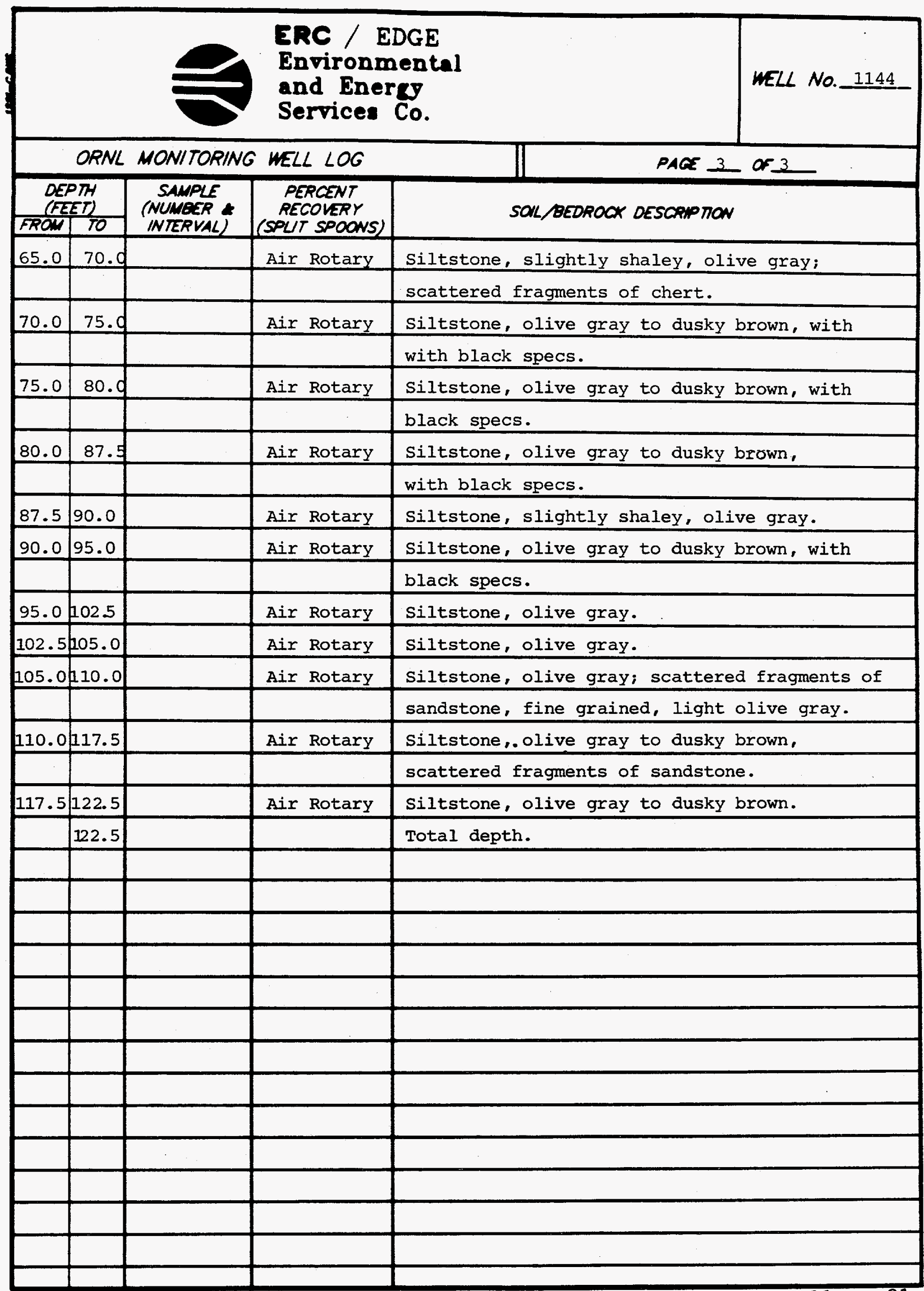




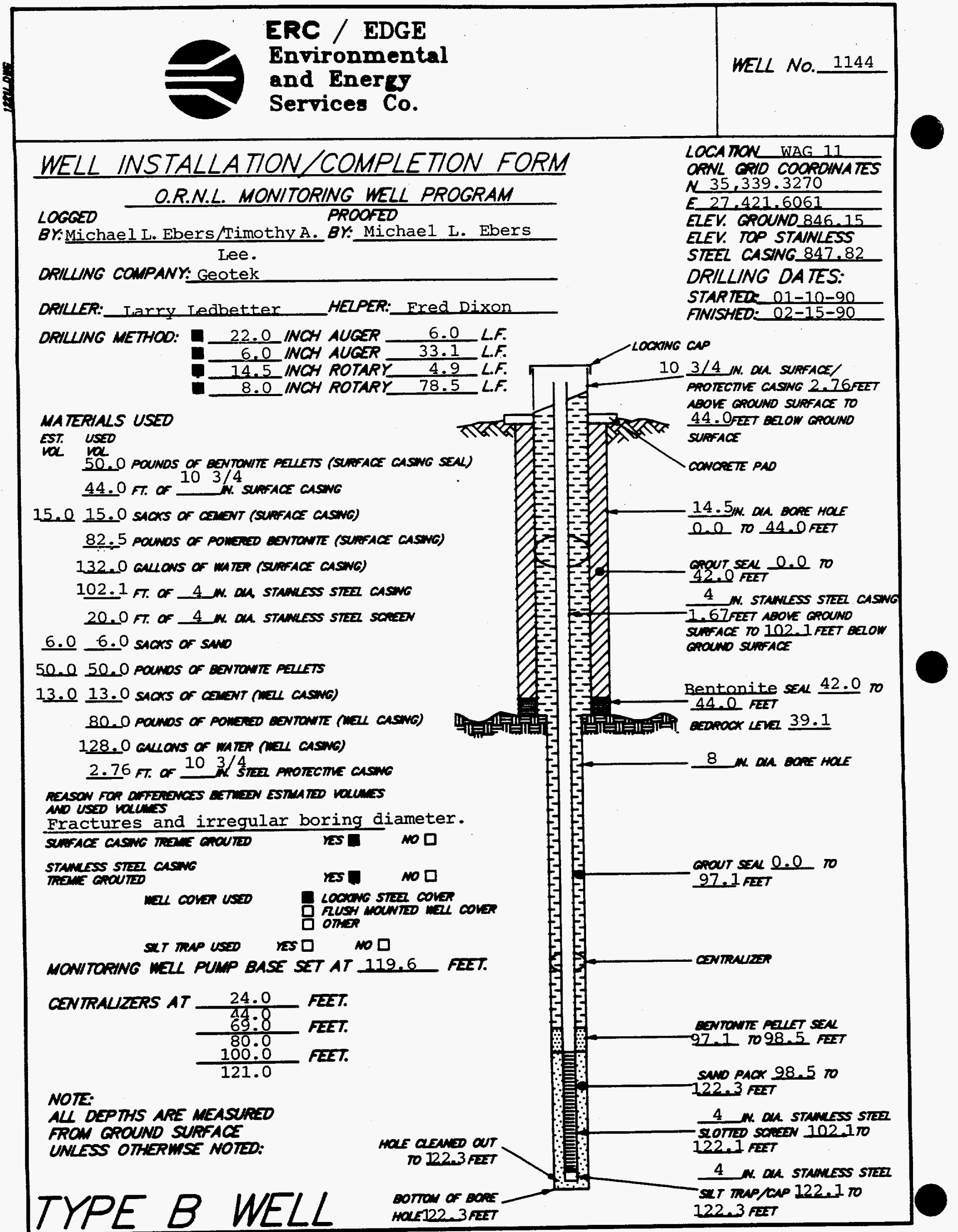

PACE 12 of 21 


\section{MONITORING WELL MATERIALS CERTIFICATION}

ITEM/MA TERIAL DATE USED BATCH NUMBER

SAND

BENTONITE

Pellets

Powder

STAINLESS STEEL SCREEN

STAINLESS STEEL CASING

STAINLESS STEEL CENTRALIZERS

STAINLESS STEEL CAPS

MONITORING WELL PUMP

GROUT

We11 Casing

Surface

(PREPACKAGED

(PREPACKAGED

(PREPACKAGED

(PREPACKAGED

\begin{tabular}{|c|c|c|}
\hline $\begin{array}{l}\text { YES } \\
\text { NO }\end{array}$ & $02-15-90$ & 2 \\
\hline $\begin{array}{c}\text { YES } \\
\text { nO }\end{array}$ & $02-15-90$ & 2 \\
\hline $\begin{array}{c}\text { VES } \\
\text { NO }\end{array}$ & $02-15-90$ & 2 \\
\hline $\begin{array}{cc}\text { YES } \\
\text { NO }\end{array}$ & $02-15-90$ & 2 \\
\hline $\begin{array}{cc}\text { YES } \\
\text { NO }\end{array}$ & $09-12-90$ & 8 \\
\hline asing & $02-16-90$ & 5 \\
\hline Casing & $02-01-90$ & 5 \\
\hline
\end{tabular}

MELL COVERS

SURFACE CASING

02-01-90

4

COMMENTS:

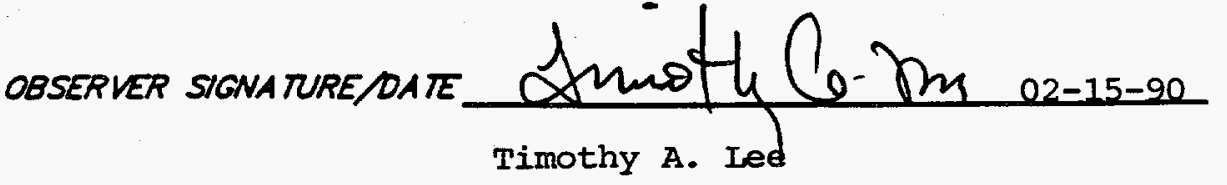

PAGE 13 OF 21. 
ERC / EDGE

Environmental

and Enerey

WELL NO. 1144

Services Co.

\section{POST-WELL COMPLETION \\ CHECKLIST}

\section{POST-WELL COMPLETION TASKS}

1. WO SCRAPED FROM AUGERS SMMPLERS ANO ML OTHER EOUIPNENT.

$$
\begin{aligned}
& \text { COMPIIANCE } \\
& \text { DA.'E INITALS }
\end{aligned}
$$

2. ALL MUO FRON RIG AND EQUPMENT SCPAPWOS ANO CUTINAS DISPOSED OF IN ACCORDANCE WIT THE SPECFCA HON PROWOED.

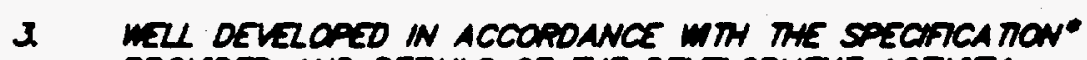
PROWOED AND DETAKS OF THE DEVZOOWENT ACIVT RECOROEO.

4. ORULNG STE PROPERLY QLANCD UP AFTLR complentor of ngL INSTALL HOW.

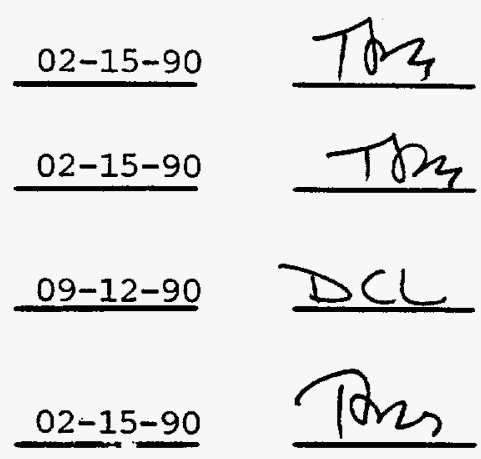

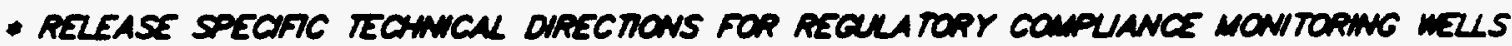

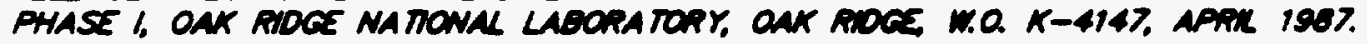

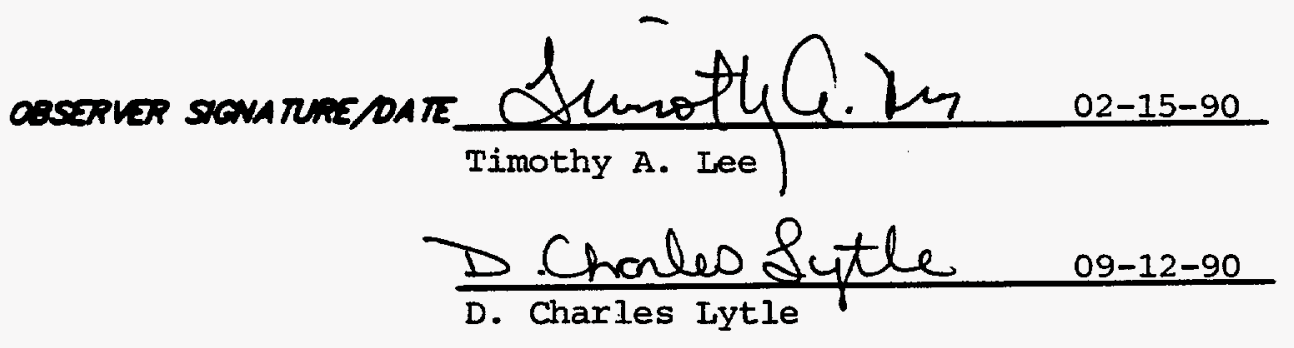




\section{MONITORING WELL \\ DEVELOPMENT FORM}

DEVELOPMENT DETAILS

METHOD OF

DEVELOPMENT: Surging and Pumping

DEVELOPMENT 08-02-90

BEGAN DATE:

$08-02-90$

TME:

DEVELOPMENT

ENDING DATE:

$09-12-90$

DEVELOPMENT

OBSERVED BY: D. Charles Lytle

ONE WELL VOLUME: 86.6 GALLONS

TOTAL GALLONS PUMPED:_ 970 TOTAL WELL VOLUMES PUMPED: 11.2

INITAL PH: 9.5 FNAL PH: 9.6

INITAL CONDUCTUTY (KS/cm): 356 FNAL CONOUCTUTY (HS/cm): 250

OESCRIPTIN OF INITAL RURBIOITY: Slightly Cloudy

OESCRIPTION OF FINAL TURBIDITY: Clean

FINAL MEASURED TURBIDITY: 5 .

WEL APPROVED BY: R.C. Williams MMES

OOOR

QF WATER: None

WA TER

DISCHARGED

TO:

GROUND SURFACE
STORM SEWERS
DRUMS

口 TANK TRUCK

I STORAGE TANKS

OTHER

INITAL PRE-DEVELOPMENT

WATER DEPTH: 21.1 feet from ground surface.

DEVELOPMENT OBSERVATIONS

OBSERVER SIGNATURE DATE D. Chanled fytlog-12-90 D. Charles Lytle 


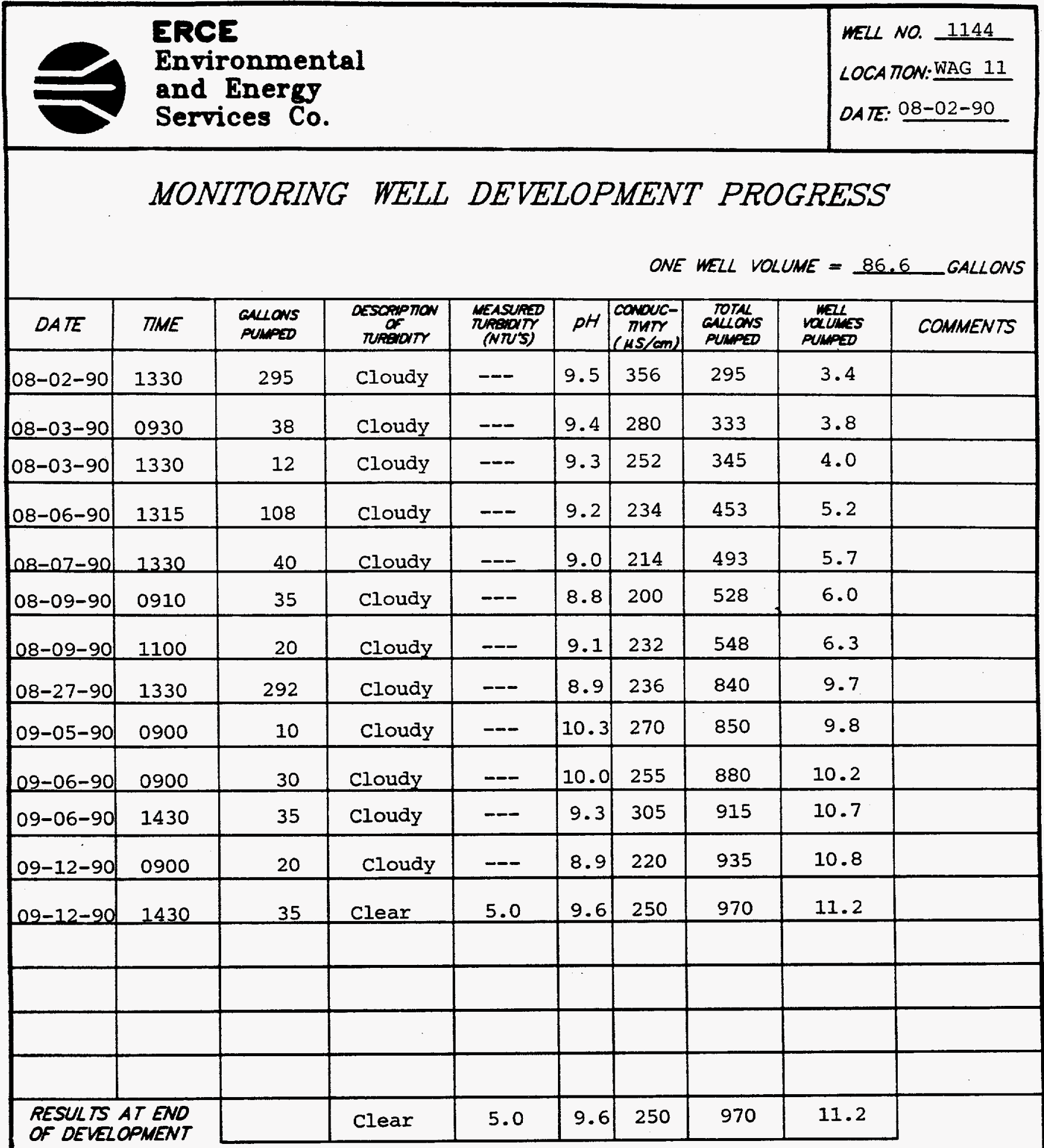

COMMENTS Okay recharger and producer. Passed with $5.0 \mathrm{NTU}$ 's and moved to another well. 
ERC / EDGE

Environmental

and Energy

Services Co.

\section{HYDRAULIC CONDUCTIVTY CALCULATIONS}

PROGRAM SLUGT, VERSION 4.1, NOV. 1986

THIS PROGRAM CALCULATES MEAN TRANSMISSIVITIES FROM

SLUG-TEST DATA BASED ON TWO ANALYTICAL APPROACHES:

(1) METHOD OF COOPER, BREDEHOEFT AND PAPADOPULOS, 1967 (ARTICLE IN VOL.3, NO.1 OF WRR ENTITLED

"RESPONSE OF A FINITE DIAMETER WELL TO AN INSTANTANEOUS CHARGE OF WATER")

(2) METHOD OF BOUWER AND RICE, 1976 (ARTICLE IN VOL. 12 , NO.3 OF WRR ENTITLED

"A SLUG TEST FOR DETERMINING HYDRAULIC CONDUCTIVITY OF UNCONFINED AQUIFERS WITH COMPLETELY OR PARTIALLY PENETRATING WELLS")

WELL NO.: 1144

DATE OF TEST: $9-20-90$

PROJECT NO.: E221-002

CLIENT: MMES

SITE LOCATION: WAG-11

EDGE, INC. FIELD INVESTIGATOR: JAMES W. CARUTHERS

INPUT DATA ARE:

INNER CASING DIAMETER $=4.00$ INCHES

INNER SCREEN OR OPEN-HOLE DIAMETER $=4.00$ INCHES

DIAMETER OF DRILLED HOLE $=8.00$ INCHES

LENGTH OF SCREEN OR INTAKE PORTION $=20.00$ FEET

DEPTH FROM STATIC LEVEL TO BOTTOM OF SCREEN $=98.70$ FEET

THICKNESS OF SATURATED AQUIFER ZONE $=20.00$ FEET

DEPTH TO STATIC WATER LEVEL BELOW REF. POINT $=1.00$ FEET

ESTIMATED POROSITY OF GRAVEL PACK $=.20$

FALLING-HEAD INDEX $=1$ ("1" IF FALLING,"0" IF RISING)

NUMBER OF DEPTH-TIME DATA POINTS $=27$

HO WAS COMPUTED FROM INTERCEPT OF PLOT OF LOG(H) VS. TIME

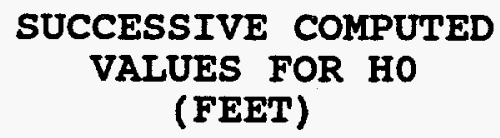

2.6631

2.6641 


\section{HYDRAULIC CONDUCTIVTY CALCULATIONS}

$\begin{array}{rcr}\text { TIME } & \text { DEPTH TO WATER } & \begin{array}{r}\text { HEAD } \\ (\text { SEC }\end{array} \\ 10.00 & (\text { FEET) } \\ 20.00 & 3.690 & \\ 30.00 & 3.680 & 2.690 \\ 40.00 & 3.690 & 2.680 \\ 50.00 & 3.690 & 2.690 \\ 60.00 & 3.690 & 2.690 \\ 75.00 & 3.690 & 2.690 \\ 90.00 & 3.660 & 2.690 \\ 105.00 & 3.650 & 2.660 \\ 120.00 & 3.650 & 2.650 \\ 150.00 & 3.650 & 2.650 \\ 180.00 & 3.650 & 2.650 \\ 240.00 & 3.630 & 2.650 \\ 300.00 & 3.630 & 2.630 \\ 360.00 & 3.610 & 2.630 \\ 420.00 & 3.610 & 2.610 \\ 480.00 & 3.610 & 2.610 \\ 540.00 & 3.610 & 2.610 \\ 600.00 & 3.630 & 2.610 \\ 720.00 & 3.650 & 2.630 \\ 840.00 & 3.650 & 2.650 \\ 960.00 & 3.660 & 2.650 \\ 1080.00 & 3.610 & 2.660 \\ 1200.00 & 3.610 & 2.610 \\ 1320.00 & 3.610 & 2.610 \\ 1440.00 & 3.610 & 2.610 \\ 1560.00 & 3.600 & 2.610 \\ & 3.610 & 2.600 \\ & & 2.610\end{array}$


ERC / EDGE

Environmental

and Energy

WELL No. 1144

Services Co.

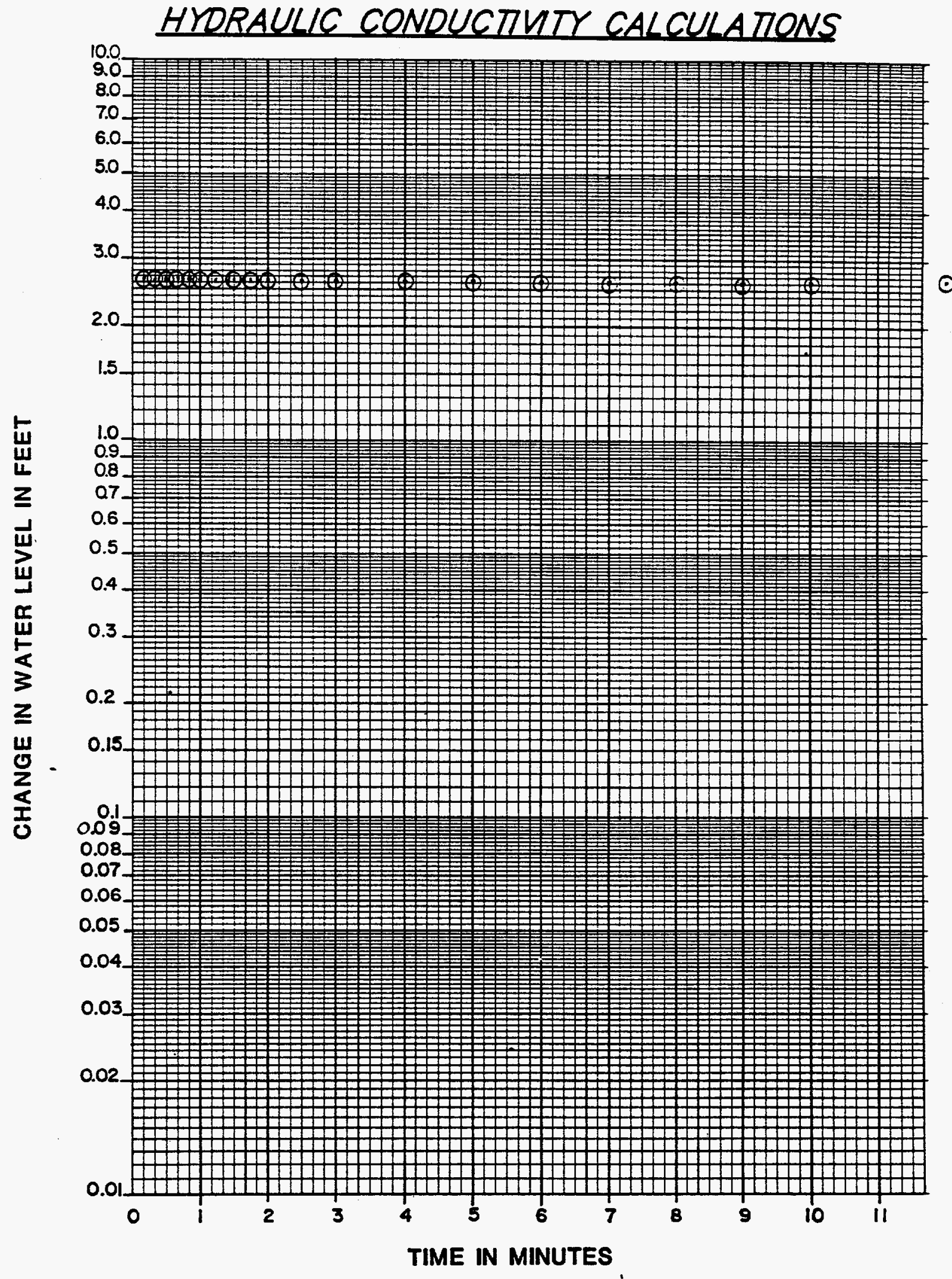

PACE 20 of 21 


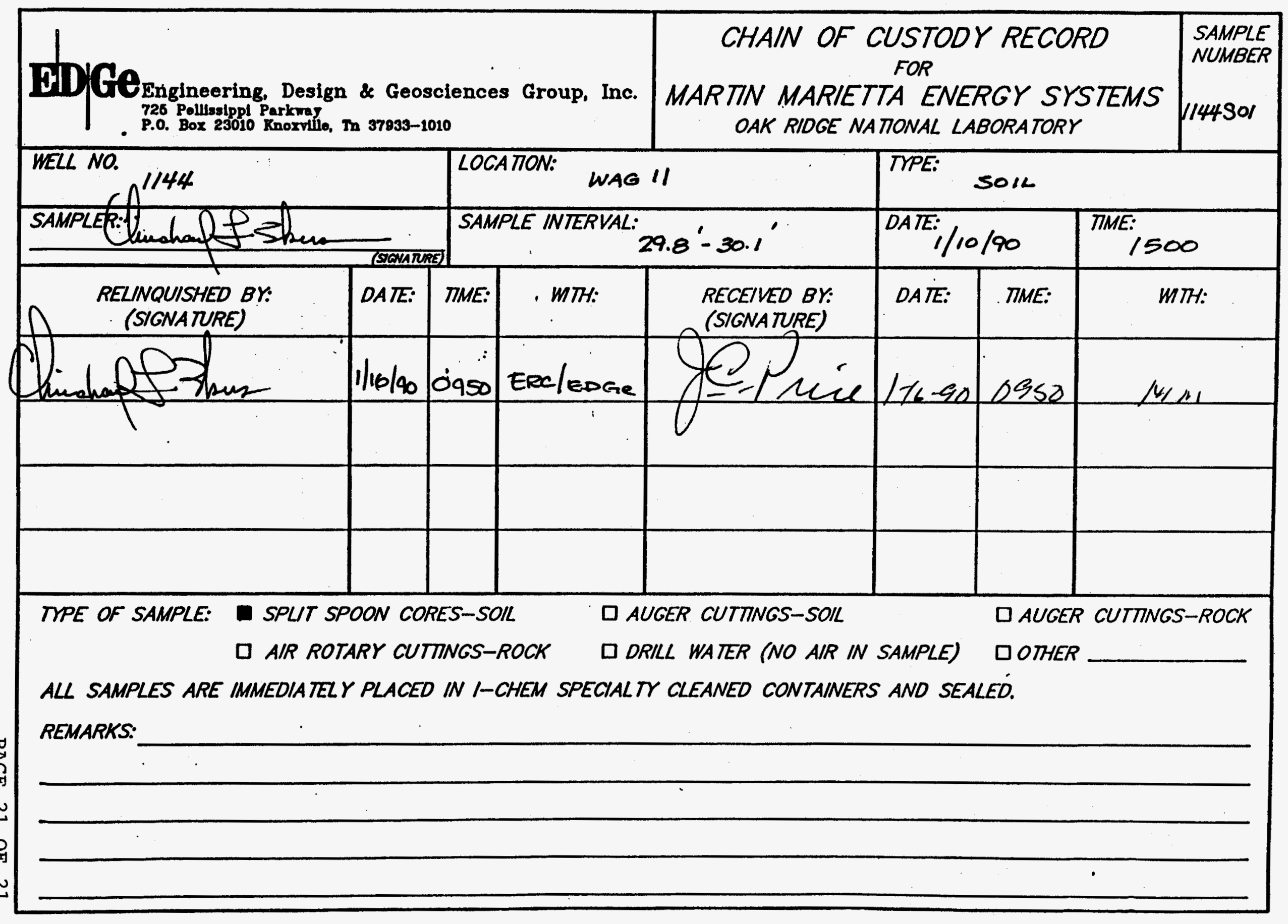




\subsection{General Information}

\subsection{Well Location}

Monitoring well number 1145 is located in WAG 11. It is located in the northwest boundary of "White wing scrap Yard" or WAG 11. The location is shown on ORNL drawing number C3E20004A075. Survey coordinates for this well are $\mathrm{N} 35,589.3486, \mathrm{E} 27,674.9621$ (X-10 grid) or latitude $35^{\circ}-57^{\prime}-08.74^{\prime \prime}$ and longitude $84^{\circ}-21^{\prime}-06.62^{\prime \prime}$. Coordinate data were provided by Martin Marietta Energy systems. The method used for conversion from $\mathrm{x}-10$ grid to Tennessee-Iambert state Plane coordinates came from the publication "Tennessee Valley Authority Data Services Branch and Mapping Services Branch, Oak Ridge, Tennessee, DOE Plant Control, November 6, 1985, Field Book: ESS-3115, pp. 1-20." The latitude and longitude were calculated by Adams Craft Herz Walker Engineering, Inc., using methods from the U.S. Coast and Geodetic survey Publication 62-4, "State Plane Coordinates by Automatic Data Processing."

\subsection{Drilling Information}

Well number 1145 was drilled by Geotek Engineering Company. An Ingersoll Rand T-4 rig was used to drill this boring for monitor well installation under operation of Larry Ledbetter with the assistance of Fred Dixon. Drilling commenced on 1-11-90 and was finished on 1-15-90. Paragraph 2.4.1 includes a detailed discussion of the well installation and a well schematic is included on the well installation/completion form. A synopsis of 
the drilling activity follows. This information was typed directly from field notes and was edited only when necessary for clarification.

1-11-90 The rig was mobilized to location and set up on plastic sheeting. Split spoon samples were taken from surface to 45.0 feet.

1-12-90 The boring was deepened from 45.0 feet to auger refusal at 59.1 feet using a 6 -inch auger. The well was bailed to 58.0 feet.

1-15-90 The boring was bailed to 59.0 feet. Two-inch stainless steel casing and screen was set with sand pack and bentonite seal.

1-16-90 The stainless steel casing was grouted into place with 6 sacks cement.

This well was logged by ERC Environmental and Energy Services Co., Inc., hydrogeologists Timothy A. Lee and Michael L. Ebers. All well construction materials and supplies were from Martin Marietta Energy Systems approved batches. The batch origin of individual items is shown on the included Monitoring Well Materials Certification form.

\subsection{Technical Information}

\subsection{Decontamination Procedures}

The drilling rig, down hole tools, surface casing, stainless steel screen, stainless steel casing, centralizers, and stainless steel silt trap underwent the cleaning decontamination procedures outlined in the drilling specifications (Release Specific Technical Directions for Regulatory Compliance Monitoring Wells 
Phase 1, Oak Ridge National Laboratory, Oak Ridge, W.0., K-4147, April 1987, pgs, 2-4). A checklist of the cleaned materials is included with this data package.

\subsection{Geology}

The northeastern half of WAG 11 is underlain by Chickamauga Iimestone. The Rome Formation underlies the southwestern half of WAG 11. The Chickamauga Limestone is brought into contact with the Rome Formation by the White Oak Mountain thrust fault, the trace of which bisects WAG 11 from northwest to southeast. The lowermost beds of the Chickamauga are composed of thin bentonitic beds, gray clay shale, and maroon to gray calcareous siltstone. The majority of the Chickamauga, approximately 1,500' thick, is a dominantly gray, dense, finely crystalline, thin bedded limestone with varying amounts of chert. The uppermost beds consist of yellow and maroon calcareous siltstone and blue-gray limestone. The Rome Formation is composed of interbedded sandstone, siltstone, shale and locally, dolomite.

\subsection{Sample Collection}

Two soil samples were collected during drilling, placed in I-CHEM specialty cleaned glass containers, sealed and submitted to sample Receiving, Analytical Chemistry Division, Bldg. 4500S, ORNL. Chain of custody forms for these samples are included with this data package. Soil sample 1145501 was collected in the split spoon interval from $20.2^{\prime}$ to $20.6^{\prime}$ on $1-11-90$ and soil sample 1145502 was collected in the split spoon interval from 27.8 to 28.4 on $1-11-90$. 
A bulk density soil sample was collected from the split spoon sample interval from 10.2' to 10.5'. The sample was measured, weighed and a bulk density of 2.30 grams $/ \mathrm{cm}^{3}$ was calculated.

\subsection{Installation and Development}

\section{4.1 Installation}

This was a Type A well. A 6-inch diameter boring was split spooned and augered from ground surface to a total depth of 59.1 feet. A 2-inch diameter stainless steel screen with welded bottom cap was installed from 38.0 feet to 59.1 feet. A 2-inch diameter stainless steel casing was installed above the screen from 38.0 feet to 2.0 feet above ground surface. A sandpack was then tremied into the annular space from 36.2 to 59.1 feet, with a 1.1 foot bentonite pellet seal poured into the annular space above the sandpack from 35.1 to 36.2 feet. The annular space from the top of the bentonite seal to the surface was tremie grouted with a cement/bentonite slurry. A detailed schematic of the well is included on the well installation/completion form.

\subsubsection{Well Development}

Well number 1145 was developed to remove drill cuttings, silt, and other fines. The monitoring was developed using a Geoguard pump with an air compressor. All pumps were cleaned prior to use according to specified cleaning procedures (see Paragraph 2.1). The well was developed until a measured total of 331 gallons of water had been evacuated and the clarity of the discharge water was approved by the company representative. The final 
turbidity value measured at completion was $>100$ NTU's. A development form showing the exact method of development and other pertinent data is appended.

\subsubsection{Installation of Dedicated Monitoring Well Pump}

After the well was developed, a Geoguard Model No. 5614 dedicated monitoring well pump was installed on 8-2-90 at a depth of 3.3 feet below ground surface. These pumps are deconta.jinated at American Sigma and are sent prepackaged. A copy of the pump certification is kept on file at ORNL.

\subsection{Eydraulic Conductivity resting}

Well number 1145 was not tested for hydraulic conductivity. The water level in the well was too low for a falling head test. A stainless steel slug would not pass by a tight spot in the well screen thus prohibiting a rising head test. 


\section{ERe / EDGE}

Environmental

and Enerey

Services Co.

\section{PRE-DRILLING CHECKLIST FOR MONITORING WELLS}

RRE-DRILUNG TASKS

1. EXCAVTION PERMIT OBTAINED

\begin{tabular}{|c|c|}
\hline \multicolumn{2}{|c|}{ COMPLIANCE } \\
\hline DAIE & INITALS \\
\hline $01-11-90$ & Whe \\
\hline $01-11-90$ & MLE \\
\hline $\mathrm{N} / \mathrm{A}$ & $N / A$ \\
\hline
\end{tabular}

30. SCREEN AND CASING HAVE BEEN WASHED, STEAMED, RINSED WTH DE-IONIZED OR DISTLLED WATER, RINSED WTH ISOPROPV ALCOHOL, WRAPPED WTH PROTECTVE COVERING AND STORED OFF THE GROUND.

36. PRE-PACKAGED SCREENS, CASING AND CENTRALIZERS WERE USED.

4. WORK AREA FOR SAMPLE EXAMINATION COVERED MTH CLEAN POL TETHRENE.

5. CLEAN KNIVES, GLOVES, SAMPLE JARS AND LABELS ON HAND.

6. POL YETHRENE COVER IN PLACE OVER HOLE.

$01-11-90$

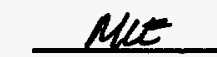

7. AIR ROTARY COMPRESSED AIR SAMPLED.

01-11-90

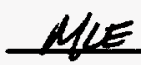

RESUL TS:

ADDITONAL NOTES/OBSERVATIONS:

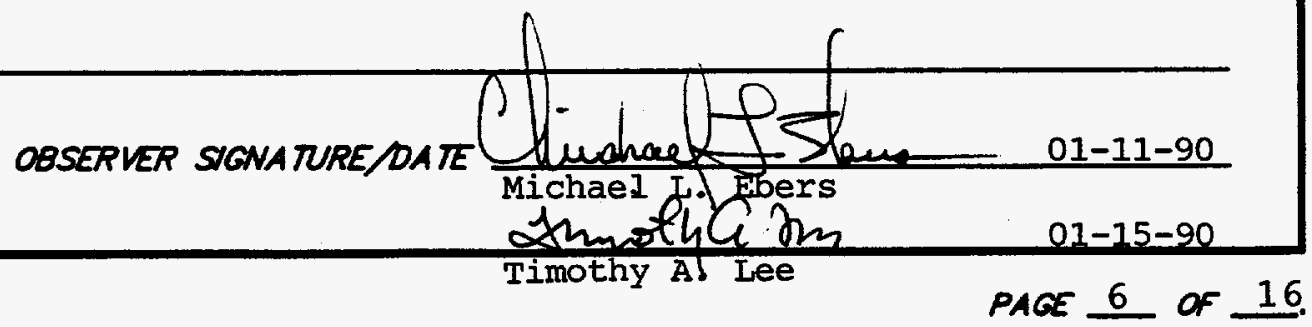


ERC / EDGE

Environmental

and Energy

Services Co.

$\frac{\text { DECONTAMINATION CHECKLIST }}{\text { DRILLING EQUIPMENT }}$

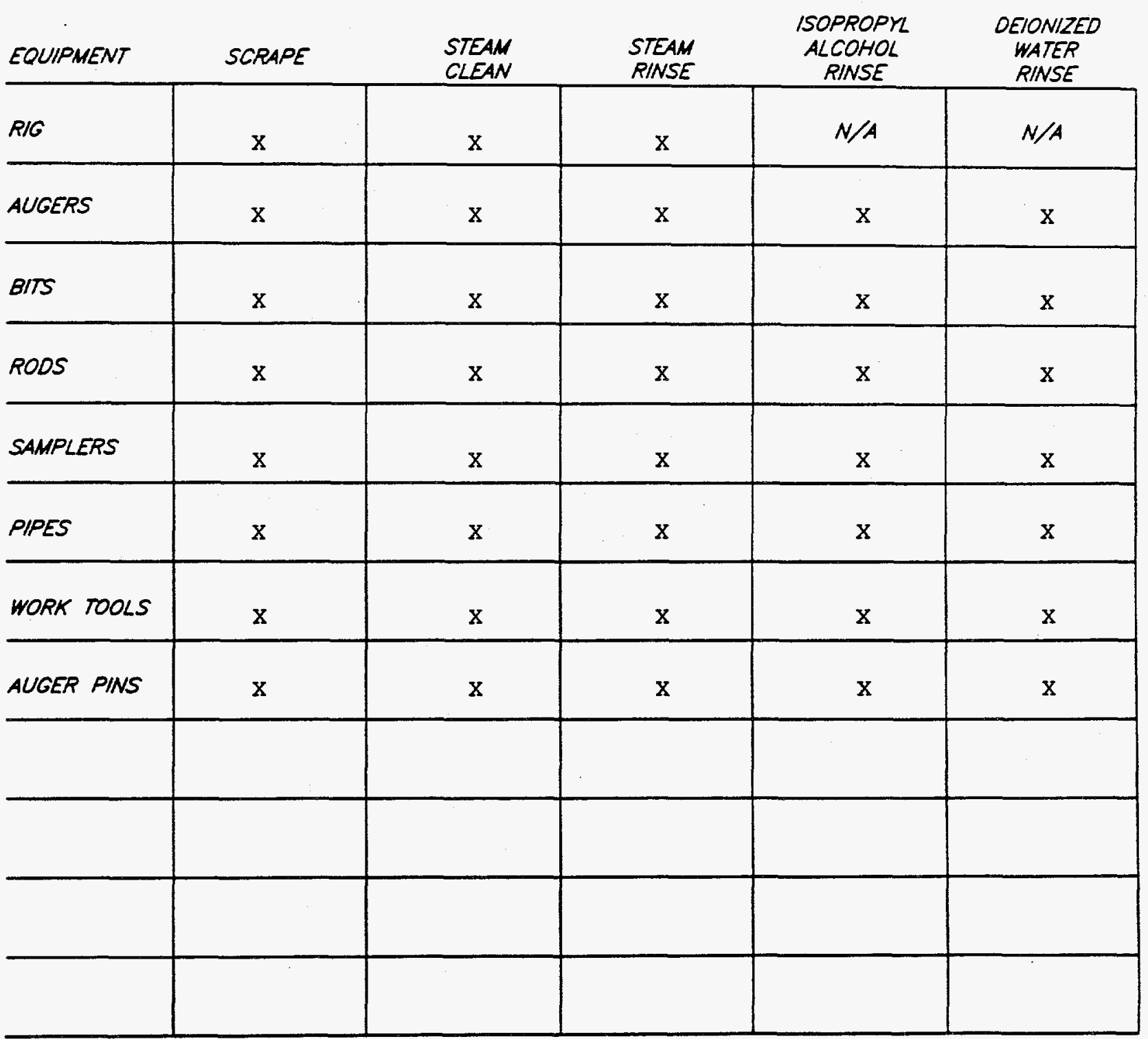

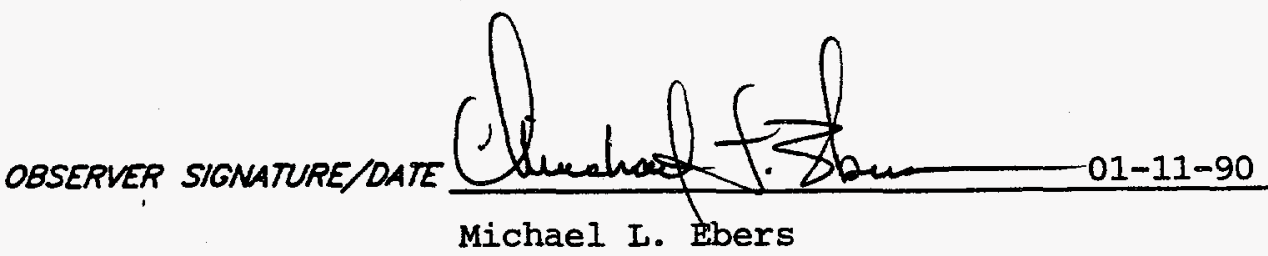

PAGE 7 OF 16. 


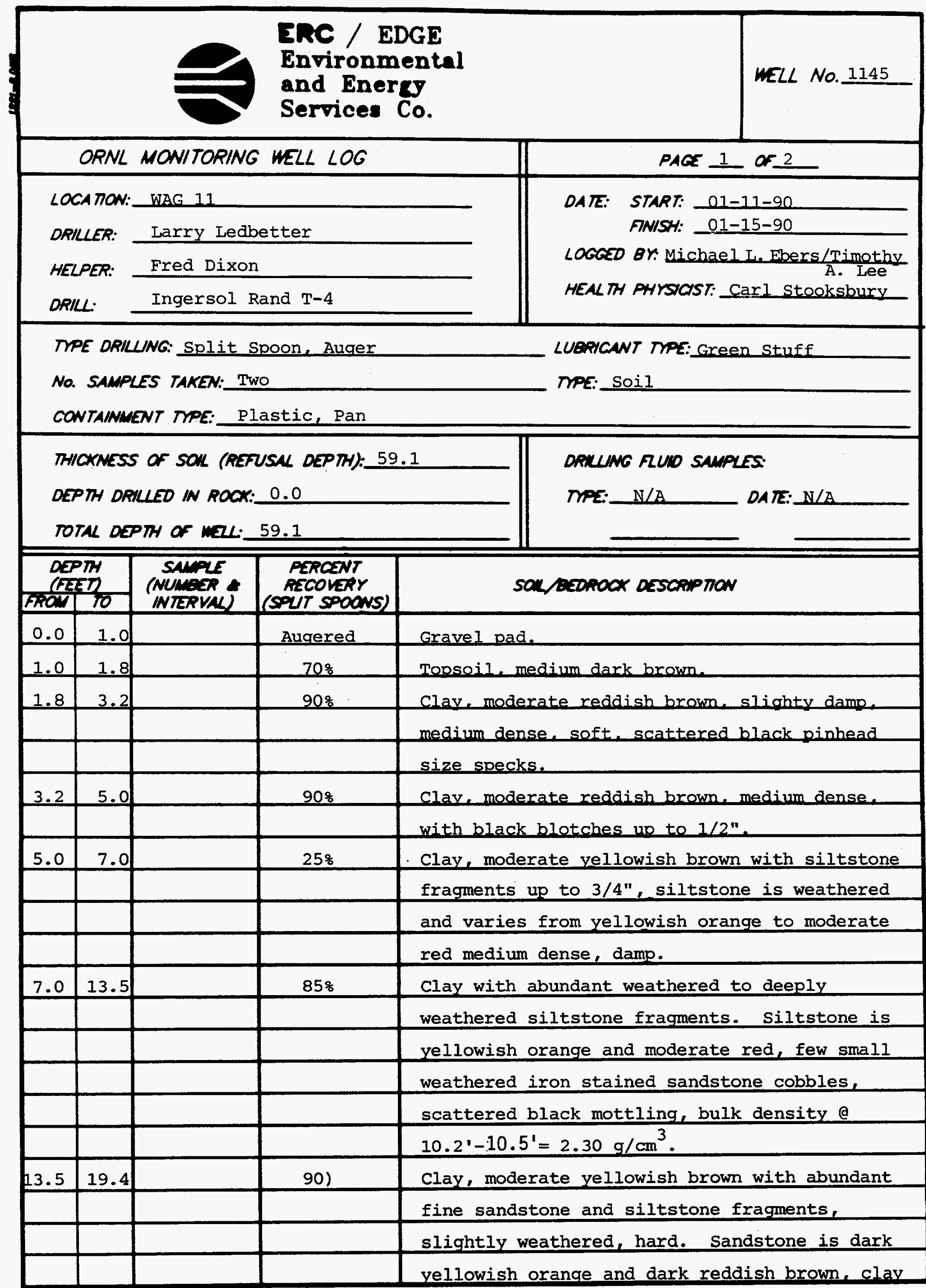




\begin{tabular}{|c|c|c|c|c|}
\hline \multicolumn{5}{|c|}{$\begin{array}{l}\text { ERC / EDGE } \\
\text { Environmental } \\
\text { and Energy } \\
\text { Services Co. }\end{array}$} \\
\hline \multicolumn{4}{|c|}{ ORNL MONITORING WELL LOG } & PAGE 2 or 2 \\
\hline \multicolumn{2}{|c|}{ 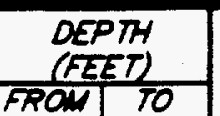 } & $\begin{array}{l}\text { SAMPLE } \\
\text { (NUMBER } *\end{array}$ & $\begin{array}{c}\text { PERCENT } \\
\text { RECOVERY }\end{array}$ & SOL BEDROCK OESCAPTION \\
\hline & & & & is damp, medium stiff. \\
\hline \multirow[t]{5}{*}{19.4} & 26.01 & $1145 S 010$ & $100 \%$ & Clay, light brown, dark yellowish orange, and \\
\hline & & $20.2^{\prime}-20.6$ & & pale olive, mottled, very dense and stiff, \\
\hline & & & & damp; black sandstone cobbles up to $1 / 2$ " in \\
\hline & & & & diameter from $24.8^{\prime}$ to clay damp, free water \\
\hline & & & & at $23^{\prime}$ (water in splitspoon). \\
\hline \multirow[t]{2}{*}{26.0} & 27.3 & & $100 \%$ & Clay, silty, yellowish orange and moderate \\
\hline & & & & yellow, damp; medium stiff. \\
\hline \multirow[t]{2}{*}{27.3} & 28.4 & $1145502 @$ & $100 \%$ & Claý, sandy, very soft, yellowish orange and \\
\hline & & & & moderate yellow. \\
\hline \multirow[t]{4}{*}{28.4} & 35.9 & & $100 \%$ & Clay, mottled, light brown, dark yellowish \\
\hline & & & & orange and pale olive, soft to medium stiff, \\
\hline & & & & moist to wet, scattered $1 / 4 "$ to $1 / 2 "$, badly \\
\hline & & & & fractured chert fragments, light olive gray. \\
\hline \multirow[t]{4}{*}{35.0} & 45.0 & & $100 \%$ & Clay, mottled, light brown and pale olive, \\
\hline & & & & medium stiff and rubbery, no silt or chert, \\
\hline & & & & moist to wet, abundant fractured chert \\
\hline & & & & fragments from $38.5^{\prime}$ to $42.0^{\prime}$ \\
\hline \multirow[t]{4}{*}{45.0} & 59.1 & & Augered & Clay, mottled, light brown and pale olive \\
\hline & & & & medium stiff and rubbery, no silt, moist to \\
\hline & & & & wet, abundant, fractured chert fragments. \\
\hline & 59.1 & & & Auger refusal and total depth. \\
\hline & & & & \\
\hline & & & & \\
\hline & & & & \\
\hline & & & & \\
\hline & & & & \\
\hline & & & & \\
\hline & & & & \\
\hline & & & & \\
\hline & & & & \\
\hline & & & & \\
\hline & & & & \\
\hline
\end{tabular}

PACE 9 or 16 


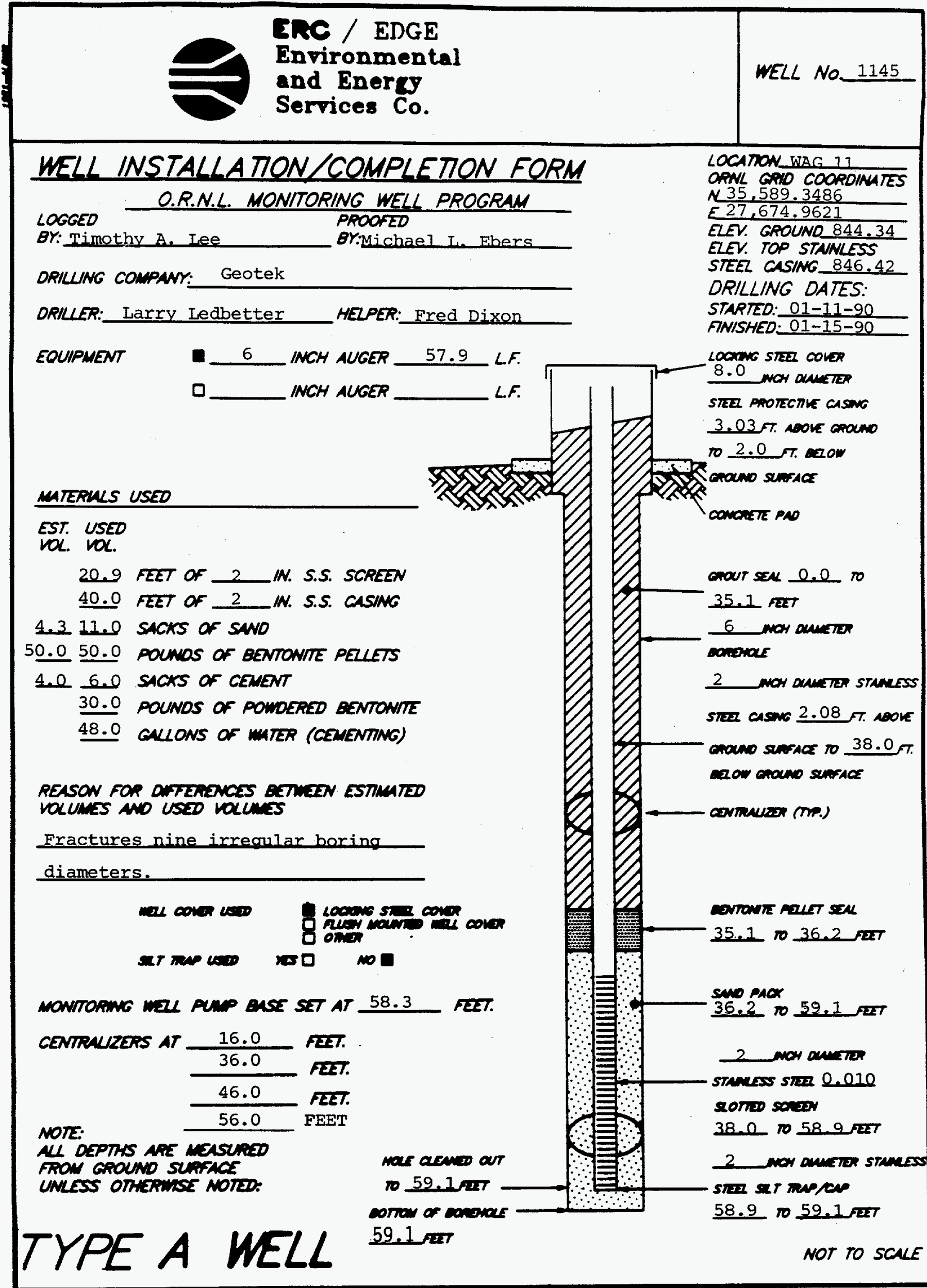


ERC / EDGE

Environmental

WELL NO. 1145

and Energy

Services Co.

OATE: $01-15-90$

\section{MONITORING WELL MATERIALS CERTIFICA TION}

ITEM/MA TERIAL

DATE USED BATCH NUMBER

SAND

BENTONITE

Powder

Pellets

\begin{tabular}{ll|l|l|l} 
(PREPACKAGED & YES & NO & 01-15-90 & MMES stores
\end{tabular}

STAINLESS STEEL SCREEN

(PREPACKAGED

STAINLESS STEEL CASING

(PREPACKAGED

STAINLESS STEEL CENTRALIZERS

STAINLESS STEEL CAPS

MONITORING WELL PUMP

(PREPACKAGED

(PREPACKAGED

\begin{tabular}{c|c}
10 \\
NO & $01-15-90$
\end{tabular}

\begin{tabular}{cc|c} 
(1ES & NO & $01-15-90$
\end{tabular}

MMES Stores

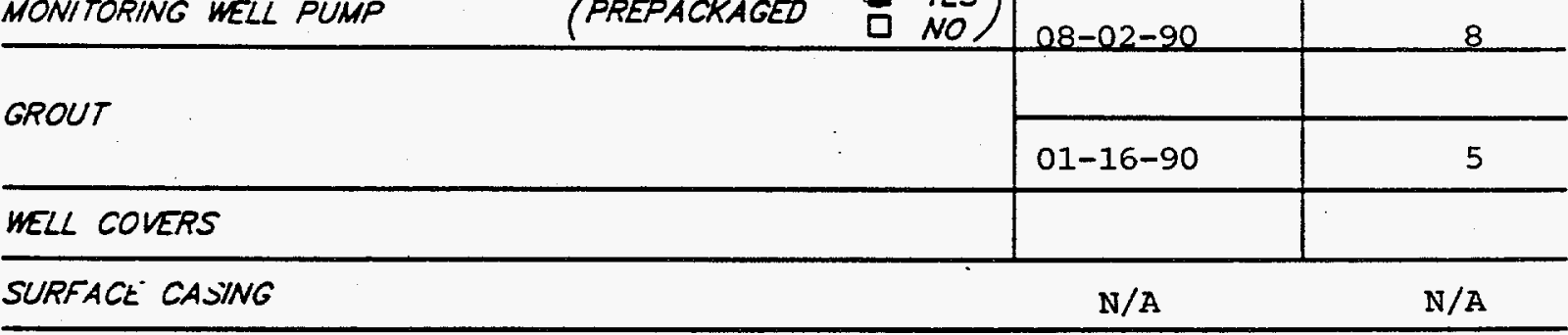

COMMENTS:

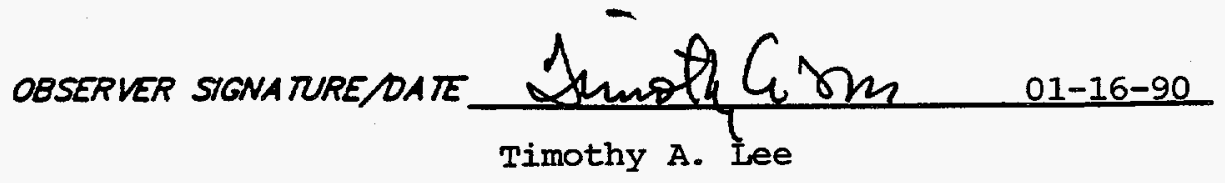

PAGE 11 of 16 


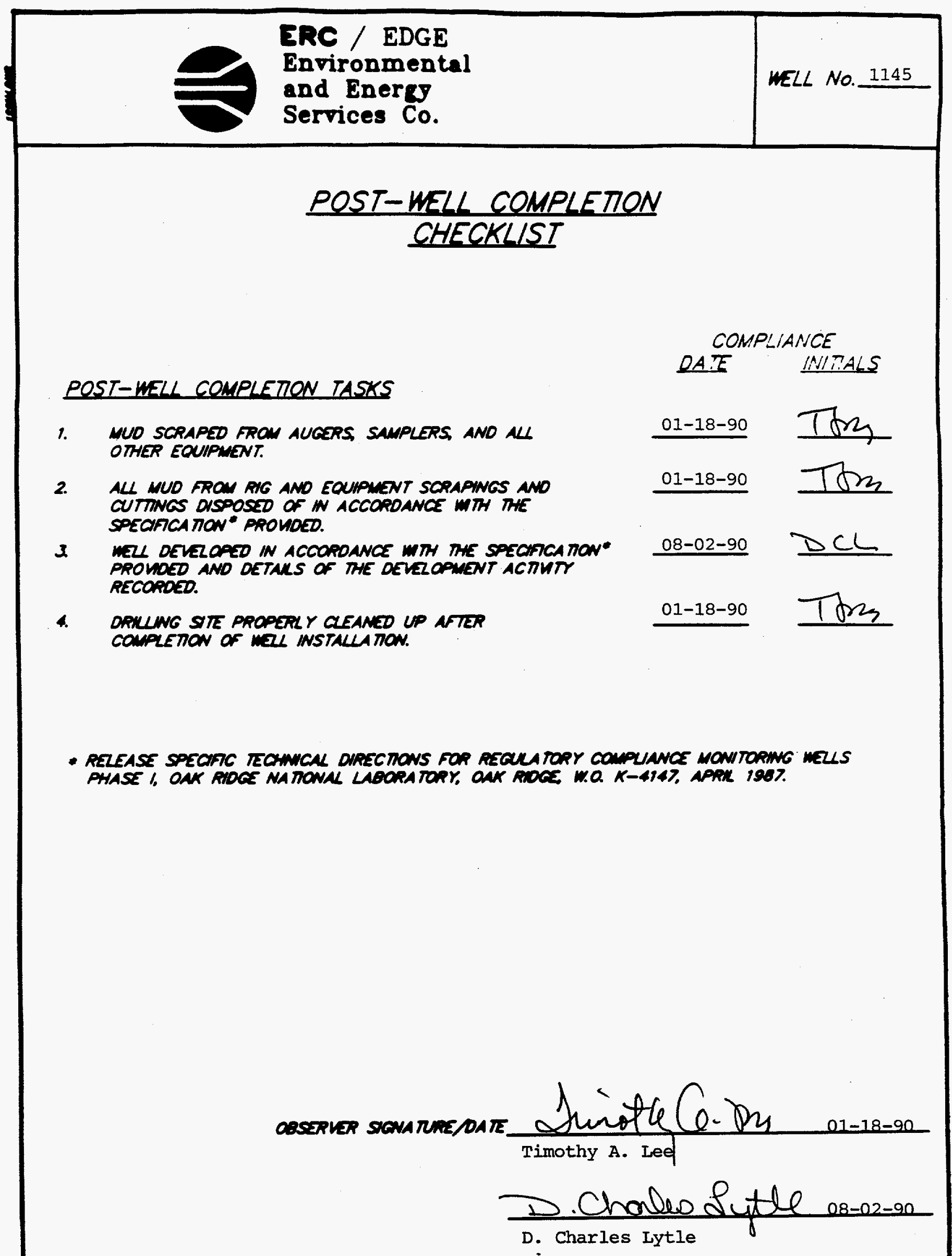

PACF 12 of 16 


\section{MONITORING WELL \\ DEVELOPMENT FORM}

\section{DEVELOPMENT DETAILS}

METHOD OF

DEVELOPMENT: Surging and Pumping

DEVELOPMENT

BEGAN DATE:

$07-31-90$ TME:

DEVELOPMENT

ENDING DATE: $\quad 08-02-90$

DEVELOPMENT

OBSERVED BY:

D. Charles Lytle

ONE WELL VOLUME: 10.8

GALLONS

TOTAL GALLONS PUMPED: 331 TOTAL WELL VOLUMES PUMPED: 30.6

INITAL PH: 8.8 FNAL PH: 8.7

INITAL CONDUCTUTY (HS/cm):__-_ FINAL CONOUCTVTY $(\mu \mathrm{S} / \mathrm{cm}): 479$

DESCRIPTON OF INITAL TURBIDIT: MUddY

DESCRIPTION OF FNAL TURBIDITY: MilkY

FNAL MEASURED TURBIDITY: $100 \mathrm{NTU}$ 's.

WEZL APPROVED BY: R.C. Williams MMES

OOOR

OF WAIER: None

WA TER G GROUNO SURFACE

DISCHARGED D STORM SEWERS

TO:

口 DRUNS

口 TANK TRUCK

STORAGE TANKS

$\square$ OTHER

INITAL PRE-DEVELOPMENT

WATER DEPTH: 52.3 feet from ground surface

\section{OEVELOPMENT OBSERVA TIONS}

OBSERVER SIGNATURE/OATE D. Phonleo \&utte 08-02-90

PAGE 13 of 16 . 


\section{ERCE \\ Environmental \\ and Energy \\ Services Co.}

\section{MONITORING WELL DEVELOPMENT PROGRESS}

ONE WELL VOLUME $=10.8$ GALLONS

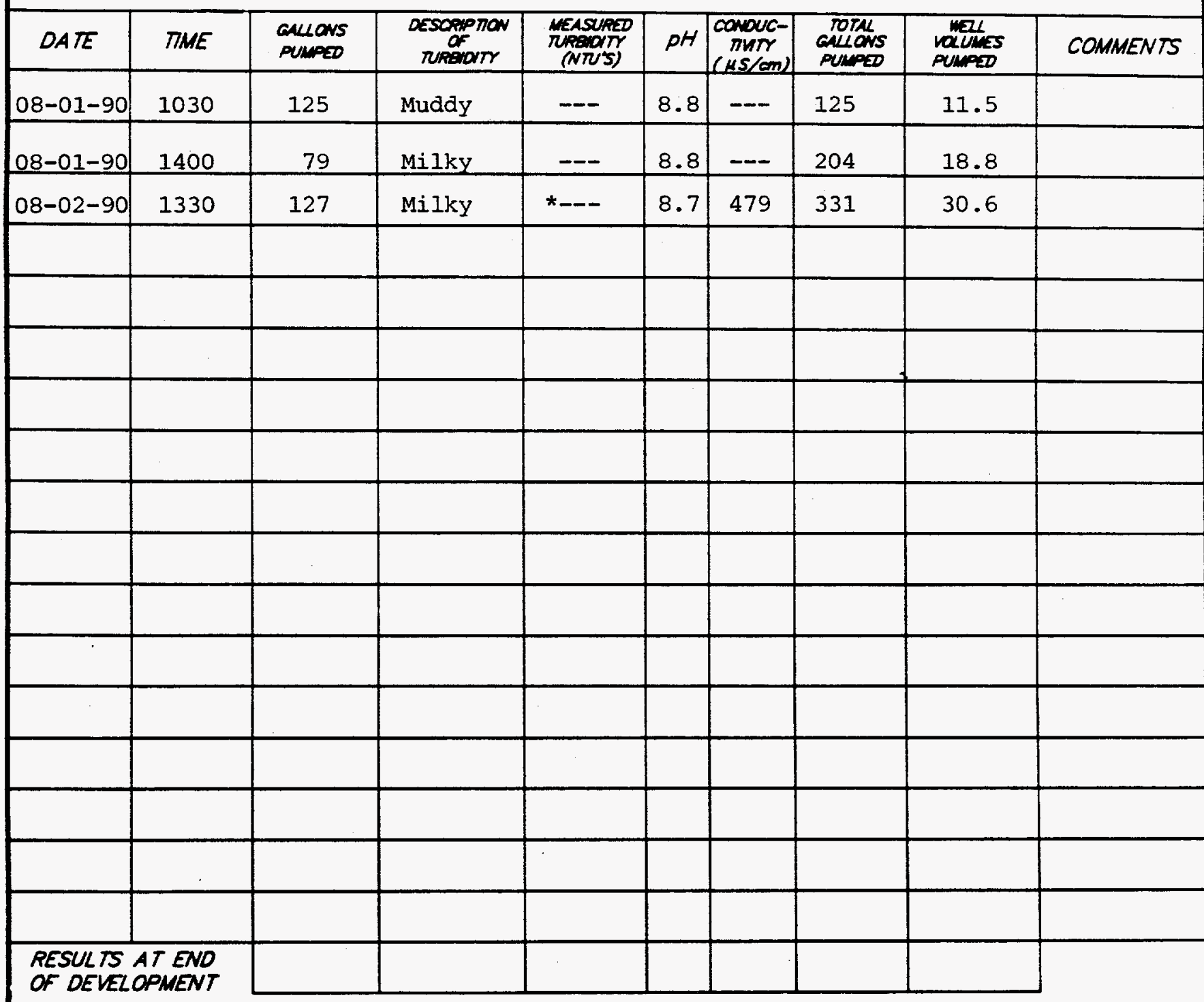

COMMENTS Good recharger and a good producer. Water would not clear up. Had to pass with 30.6 well volumes.

* 100 NTU's.

OBSERVER SIGNATURE PATE D. ChaleP Butle 08-02-90 Minconosions 


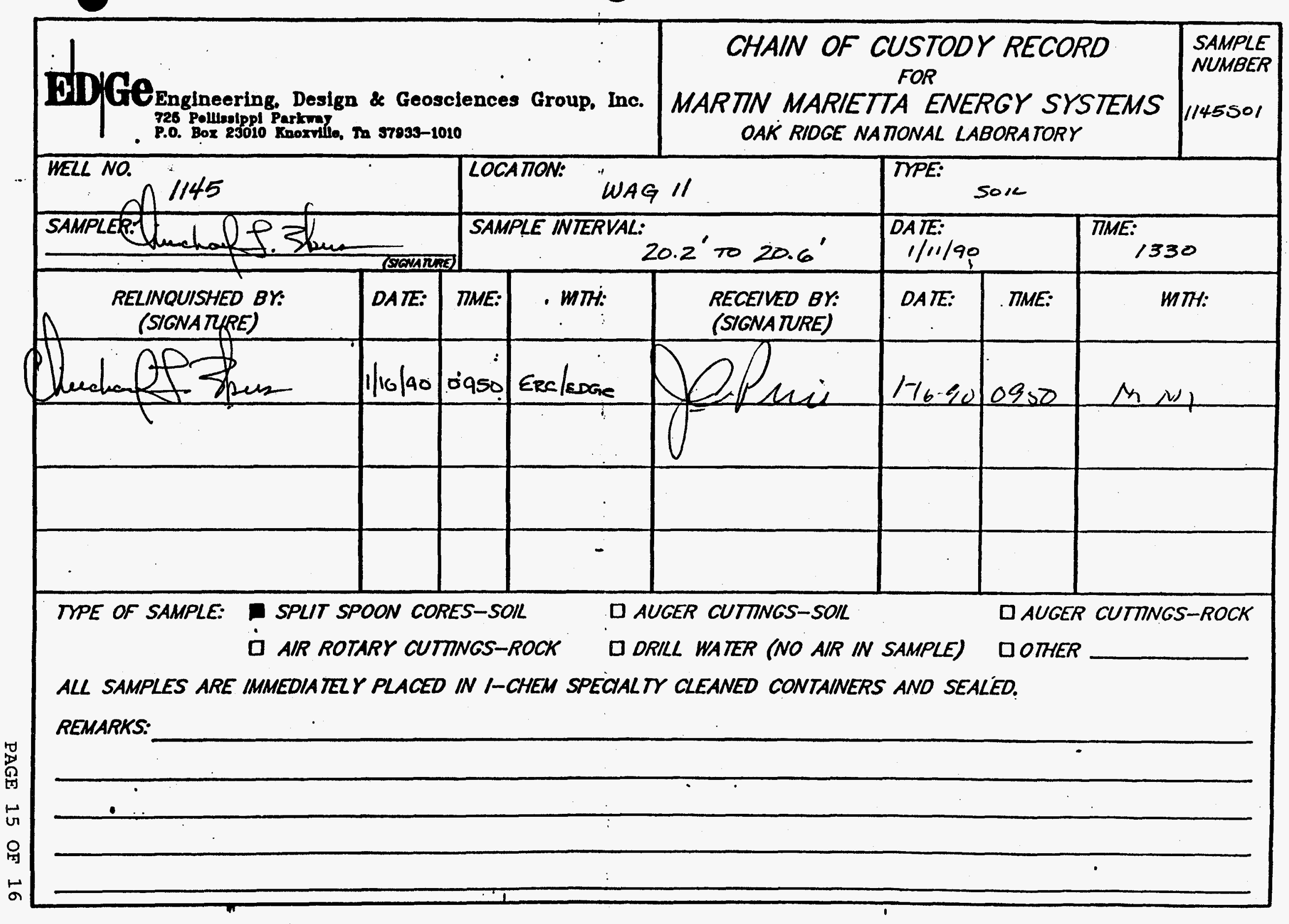




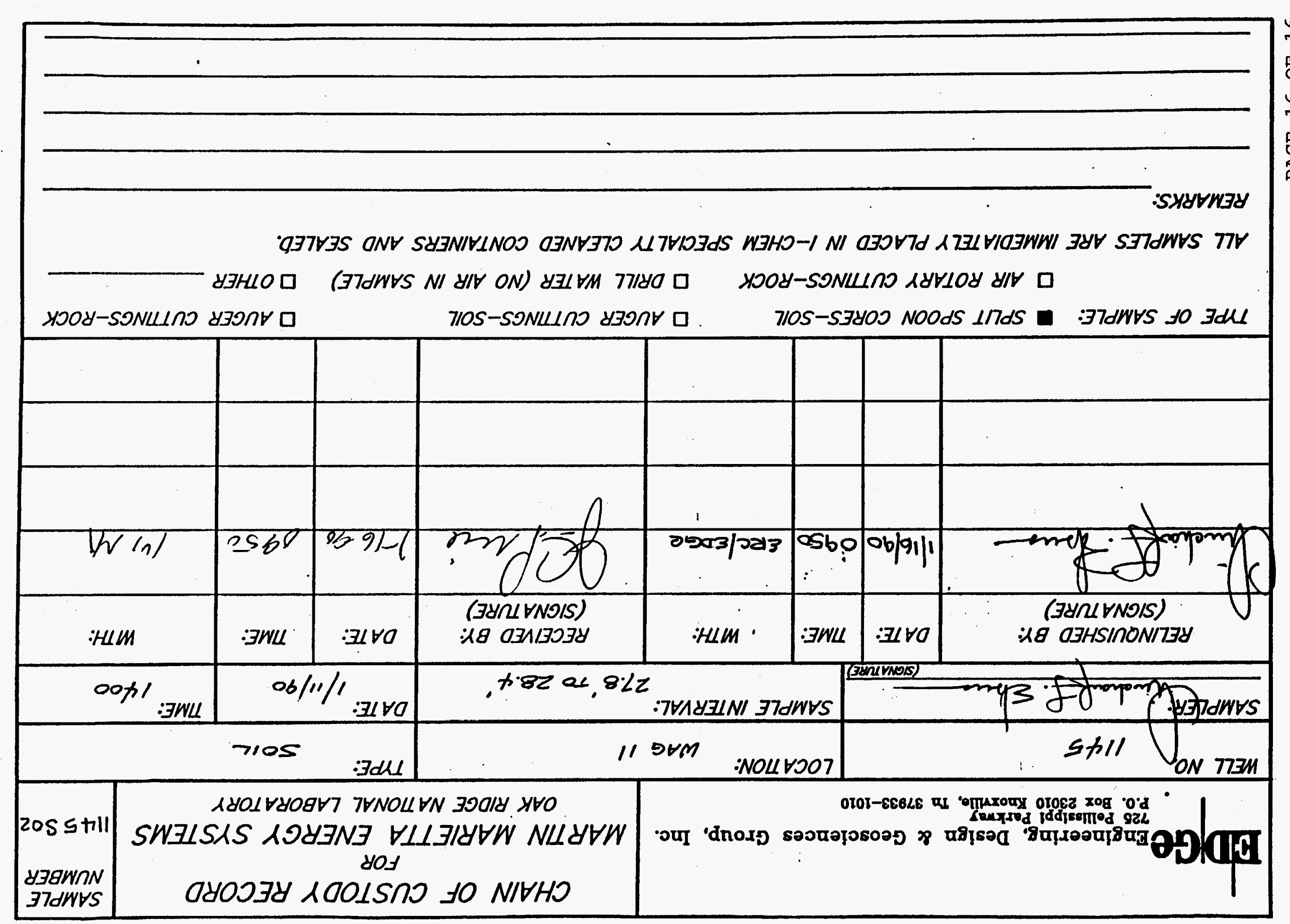




\subsection{Well Location}

Monitoring well number 1146 is located in WAG 11 . It is located in the northwestern portion of "White Wing scrap Yard" or WAG 11. The location is shown on ORNL drawing number C3E20004A075. Survey coordinates for this well are $\mathrm{N} 35,704.1986, \mathrm{E} 28,337.7057$ (X-10 grid) or latitude $35^{\circ}-57^{\prime}-13.33^{\prime \prime}$ and longitude $84^{\circ}-21^{\prime}-00.70^{\prime \prime}$. Coordinate data were provided by Martin Marietta Energy systems. The method used for conversion from $x-10$ grid to Tennessee-Lambert state Plane coordinates came from the publication "Tennessee Valley Authority Data Services Branch and Mapping Services Branch, Oak Ridge, Tennessee, DOE Plant Control, November 6, 1985, Field Book: Ess-3115, pp. 1-20." The latitude and longitude were calculated by Adams Craft Herz Walker Engineering, Inc., using methods from the U.S. Coast and Geodetic survey Publication 62-4, "State Plane Coordinates by Automatic Data Processing."

\subsection{Drilling Information}

Well number 1146 was drilled by Geotek Engineering Company. An Ingersoll Rand $\mathrm{T}-4 \mathrm{rig}$ was used to drill this boring for monitor well installation under operation of Larry Ledbetter with the assistance of Fred Dixon. Drilling commenced on 1-5-90 and was finished on 2-27-90. Paragraph 2.4.1 includes a detailed discussion of the well installation and a well schematic is included on the well installation/completion form. A synopsis of the 
drilling activity follows. This information was typed directly from field notes and was edited only when necessary for clarification.

1-4-90 The rig was mobilized to location and set up on plastic sheeting.

1-5-90 Split spoon samples were taken from surface to refusal at 38.0 feet. The boring was augered to 28.0 feet with a 14.0 -inch auger.

1-8-90 Set $103 / 4$-inch decontaminated steel diverter casing at 28.0 feet with a 2.0 feet bentonite pellet seal. The rig was moved from location. The casing annulus was grouted with 10 sacks cement.

2-22-90 Move rig to location and drill to 62.5 feet with an 8.0-inch air rotary tricone bit.

2-23-90 Drill to 122.5 feet with 8.0-inch air rotary tricone bit.

2-26-90 The well was deepened from 122.5 feet to 132.5 feet. Ran 4.0-inch stainless steel casing which stopped at 121.0 feet. Decided to pull casing and redrill hole.

2-27-90 Re-drill hole with 8.0-inch air rotary tricone bit to 132.5 feet. After pulling drill steel out of hole, weighted tape showed total depth of hole at 118.0 feet. Decide to run 4.0-inch stainless steel casing to 117.3 feet and set it with sand pack and bentonite pellet seal. The rig was moved from location.

2-28-90 Tremie grouted annulus with 25 sacks cement with flocele.*

3-2-90 Tremie grouted annulus with 27 more sacks cement with flocele. 


$$
\begin{array}{ll}
\text { 3-6-90 } & \text { Tremie grouted annulus with } 12 \text { more sacks } \\
\text { cement with flocele. } \\
\text { 3-7-90 Tremie grouted annulus with } 1 \text { more sack cement } \\
\text { to surface. }
\end{array}
$$

* After the stainless steel casing was set with sandpack and bentonite seal, 30.0 feet of P.V.C. tremie pipe was dropped into the annulus of this well. After a few attempts to "fish", this pipe was encapsulated in the grout.

This well was logged by ERC Environmental and Energy Services Co., Inc., hydrogeologist Timothy A. Lee. All well construction materials and supplies were from Martin Marietta Energy systems approved batches. The batch origin of individual items is shown on the included Monitoring Well Materials Certification form.

\subsection{Technical Information}

\subsection{Decontamination Procedures}

The drilling rig, down hole tools, surface casing, stainless steel screen, stainless steel casing, centralizers, and stainless steel silt trap underwent the cleaning decontamination procedures outlined in the drilling specifications (Release specific Technical Directions for Regulatory Compliance Monitoring Wells Phase 1, Oak Ridge National Laboratory, Oak Ridge, W.o., K-4147, April 1987, pgs, 2-4). A checklist of the cleaned materials is included with this data package. 


\subsection{Geology}

The northeastern half of WAG 11 is underlain by Chickamauga Limestone. The Rome Formation underlies the southwestern half of WAG 11. The Chickamauga Limestone is brought into contact with the Rome Formation by the White oak Mountain thrust fault, the trace of which bisects WAG 11 from northwest to southeast. The lowermost beds of the Chickamauga are composed of thin bentonitic beds, gray clay shale, and maroon to gray calcareous siltstone. The majority of the Chickamauga, approximately 1,500' thick, is a dominantly gray, dense, finely crystalline, thin bedded limestone with varying amounts of chert. The uppermost beds consist of yellow and maroon calcareous siltstone and blue-gray limestone. The Rome Formation is composed of interbedded sandstone, siltstone, shale and locally, dolomite.

\section{3 sample collection}

One soil sample was collected during drilling, placed in an I-CHEM specialty cleaned glass container, sealed and submitted to Sample Receiving, Analytical Chemistry Division, Bldg. 4500S, ORNL. A chain of custody form for this sample is included with this data package. Soil sample 1146501 was collected in the split spoon interval from $37.0^{\prime}$ to $38.0^{\prime}$ on $1-5-90$.

A bulk density soil sample was collected from the split spoon sample interval from $4.1^{\prime}$ to $4.5^{\prime}$. The sample was measured, weighed and a bulk density of $1.74 \mathrm{grams} / \mathrm{cm}^{3}$ was calculated. 
ERC / EDGE

Environmental

and Energy

Services Co.

The Ingersoll Rand T-4 compressed air was sampled with a cloth filter inserted between drill rods on 2-26-90. The sample was examined with an ultraviolet light for the presence of hydrocarbons. The filter showed no detectable signs of hydrocarbons.

\subsection{Installation and Development}

\subsubsection{Installation}

This was a Type B well. A 14.0-inch diameter boring was augered from surface to 28.0 feet. A 10 3/4-inch diameter string of decontaminated steel surface casing was installed from 0.0 feet to 28.0 feet, sealed with a 2.0 foot bentonite pellet layer from 26.0 feet to 28.0 feet, and tremie grouted in place. The surface casing minimizes potential cross contamination between the regolith and bedrock water bearing zones. After the surface casing was installed, the air rotary method was used to drill an 8-inch diameter boring to a total depth of $132.5 \mathrm{fc}$ at. A 4-inch diameter stainless steel screen with threaded bottom cap was installed from 107.1 feet to 117.3 feet. A 4-inch diameter stainless steel casing was installed from the top of the screen at 107.1 feet and extended 2.9 feet above ground surface. A sandpack was then tremied into the annular space from 103.8 to 117.3 feet, with a 1.4 foot bentonite pellet seal poured into the annular space above the sandpack from 102.4 to 103.8 feet. The annular space from the top of the bentonite seal to the surface was tremie grouted with a cement/bentonite slurry. A detailed schematic of the well is included on the well installation/ completion form. 
ERC / EDGE

Environmental

and Energy

Services Co.
MONITORING WELL PROGRAM

WELL OATA NARRATVE

MELL NO. 1146

\subsubsection{Well Development}

Well number 1146 was developed to remove drill cuttings, silt, and other fines. The monitoring was developed using a Geoguard pump with an air compressor. All pumps were cleaned prior to use according to specified cleaning procedures (see Paragraph 2.1). The well was developed until a measured total of 501 gallons of water had been evacuated and the clarity of the discharge water was approved by the company representative. The final turbidity value measured at completion was 2.0 NTU's. A development form showing the exact method of development and other pertinent data is appended.

\subsubsection{Installation of Dedicated Monitoring Nell Pump}

After the well was developed, a Geoguard Model No. 5614 dedicated monitoring well pump was installed on 8/9/90 at a depth of 112.0 feet below ground surface. These pumps are decontaminated at American sigma and are sent prepackaged. A copy of the pump certification is kept on file at ORNL.

\subsection{Hydraulic Conductivity Testing}

Well number 1146 was tested for the determination of hydraulic conductivity of the aquifer in the vicinity of the well screen. This was accomplished by instantaneously adding a known quantity of water to the monitoring well and measuring the recovery of the water level over time. The changing water levels were measured using a Druck 15 psi pressure transducer and an Omnidata Datapod II data recorder. The hydraulic conductivity value of $1.06 \times 10^{-4} \mathrm{~cm} / \mathrm{second}$ (shown as permeability on 
ERC / EDGE

Environmental

and Energy

Services Co.
MONITORING WELL PROGRAM

WEZL OATA NARRATIE

WELL NO. 1146

the hydraulic conductivity calculations printout attached) was calculated using the Bouwer and Rice method. A computer printout of the hydraulic conductivity calculations is included in this data package. 


\section{PRE-DRILLING CHECKLIST FOR MONITORING WELLS}

PRE-ORILUNG TASKS

1. EXCAVTION PERMIT OBTAINED

2. ALL EOUIPMENT HAS BEEN CLEANED BEFORE ORILLING.

30. SCREEN AND CASING HAVE BEEN WASHED, STEAMED, RINSED WIH DE-IONIZED OR DISTLLED WATER, RINSED WTH ISOPROPN ALCOHOL, WRAPPED WTH PROTECTVE COVERING AND STORED OFF THE GROUND.

3b. PRE-PACKAGED SCREENS, CASING AND CENTRALIZERS MERE USED.

4. WORK AREA FOR SAMPLE EXAMINATION COVERED WTH CLEAN POL TETHRENE.

5. CLEAN KNIVES, GLOVES, SAMPLE JARS ANO LABELS ON HAND.

6. POL YETHKENE COVER IN PLACE OVER HOLE.

7. AIR ROTARY COMPRESSED AIR SAMPLED.

\section{COMPLIANCE}

DAIE

01-04-90

N/A
$01-04-90$

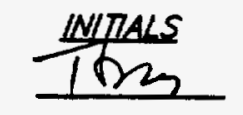

Tres

$\mathrm{N} / \mathrm{A}$

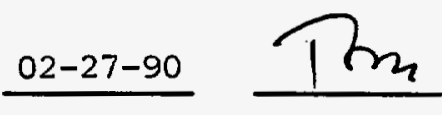

$01-04-90$

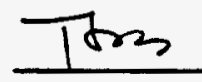

$01-05-90$

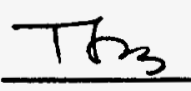

01-05-90

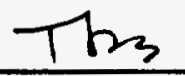

$\underline{02-26-90}$

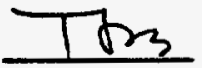

RESULTS: Showed no detectable signs of hydrocarbons under ultra violet liqht.

ADOITONAL NOTES/OBSERVATONS:

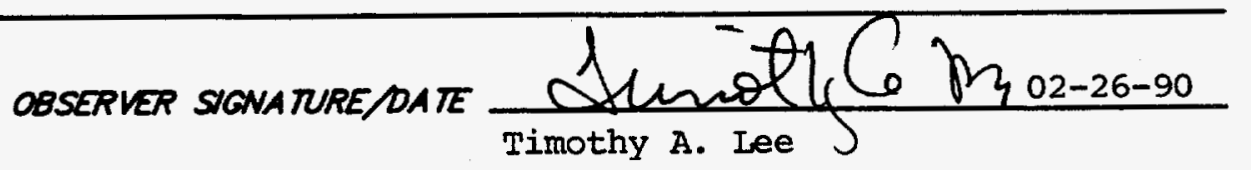




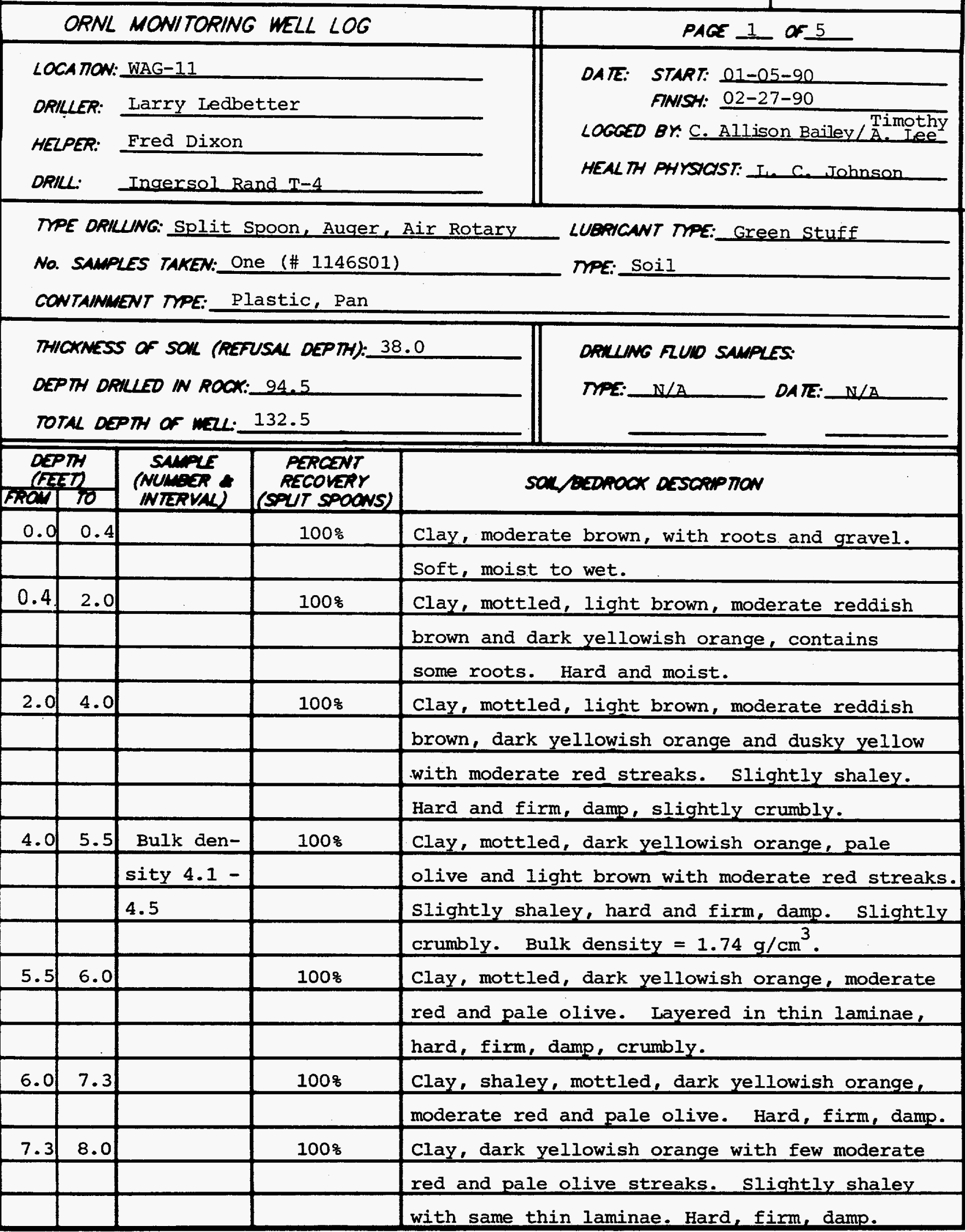




\begin{tabular}{|c|c|c|c|c|}
\hline \multicolumn{5}{|c|}{$\begin{array}{l}\text { SRe / E } \\
\text { Environn } \\
\text { and Enes } \\
\text { Services }\end{array}$} \\
\hline \multicolumn{5}{|c|}{ ORNL MONITORING WELL LOG } \\
\hline \multicolumn{2}{|c|}{$\begin{array}{l}\text { OEPTH } \\
\text { (FEET) }\end{array}$} & $\begin{array}{l}\text { SAMPLE } \\
\text { (NUMBER \& } \\
\text { INTERVAL) }\end{array}$ & $\begin{array}{c}\text { PERCENT } \\
\text { RECOVERY } \\
\text { (SPUT SPOONS) } \\
\end{array}$ & SOL/BEDROAK DESCPIPION \\
\hline \multirow{2}{*}{8.0} & 9.0 & & Augered & Clay, dark yellowish orange, moderate red and \\
\hline & & & & pale olive, slightly shaiey. Firm, damp. \\
\hline \multirow[t]{3}{*}{9.0} & 10.3 & & $100 \%$ & Clay, dark yellowish orange with few moderate \\
\hline & & & & red and pale olive streaks. Slightly shaley \\
\hline & & & & with some thin laminae. Hard, firm, damp. \\
\hline \multirow[t]{5}{*}{10.3} & 11.0 & & $100 \%$ & Clay, shaley, mottled, pale olive, pale red \\
\hline & & & & and dark yellowish orange. Contains thin \\
\hline & & & & laminae. Some layers are dark black (iron \\
\hline & & & & stained or organic mineral), slightly crumbly, \\
\hline & & & & firm, dry to damp. \\
\hline \multirow[t]{2}{*}{11.0} & 12.5 & & $100 \%$ & Clay, dark yellowish orange, firm, partially \\
\hline & & & & crumbly, damp to moist. \\
\hline \multirow[t]{4}{*}{12.5} & 13.0 & & 1008 & Clay, mottled, dark yellowish orange and \\
\hline & & & & moderate reddish brown. Layered with thin \\
\hline & & & & beds. Some layers are pale olive and dark \\
\hline & & & & brown. Hard and firm. Damp to moist. \\
\hline \multirow[t]{4}{*}{13.0} & 15.0 & & $100 \%$ & Clay, mottled, dark yellowish orange with \\
\hline & & & & some moderate reddish brown. Layered with \\
\hline & & & & thin beds. Some layers are dark brown. Hard \\
\hline & & & & and firm. Damp to moist. \\
\hline \multirow[t]{4}{*}{15.0} & 17.0 & & & Clay, shaley, dark yellowish orange with \\
\hline & & & & moderate reddish brown streaks and contains \\
\hline & & & & dark mineral streaks. Contains thin laminae \\
\hline & & & & of pale olive. Soft and firm, moist. \\
\hline \multirow[t]{4}{*}{17.0} & 19.0 & & $100 \%$ & Clay, dark yellowish orange with moderate \\
\hline & & & & reddish brown streaks and dark mineral streaks \\
\hline & & & & with some pale olive. Soft, very clayey, \\
\hline & & & & moist to wet. \\
\hline \multirow[t]{5}{*}{19.0} & 21.0 & & $100 \%$ & Clay, dark yellowish orange with moderate \\
\hline & & & & reddish brown streaks and pale olive. Soft, \\
\hline & & & & very clayey, moist to wet. From 20.0 to 20.3 \\
\hline & & & & there is a shaley layer which is dark brown \\
\hline & & & & to black (Orange mineral). \\
\hline
\end{tabular}

PACE 11 of 24. 


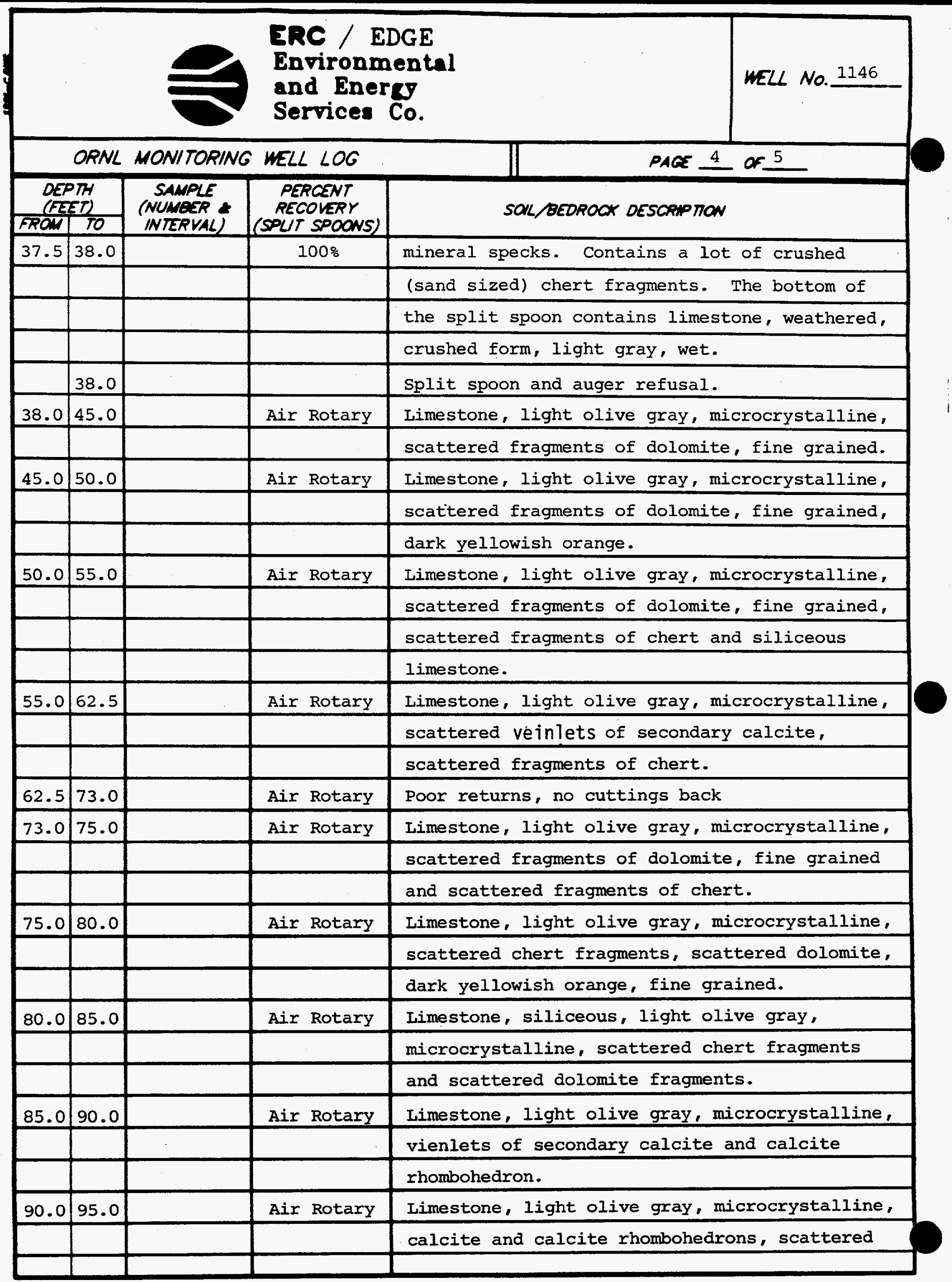




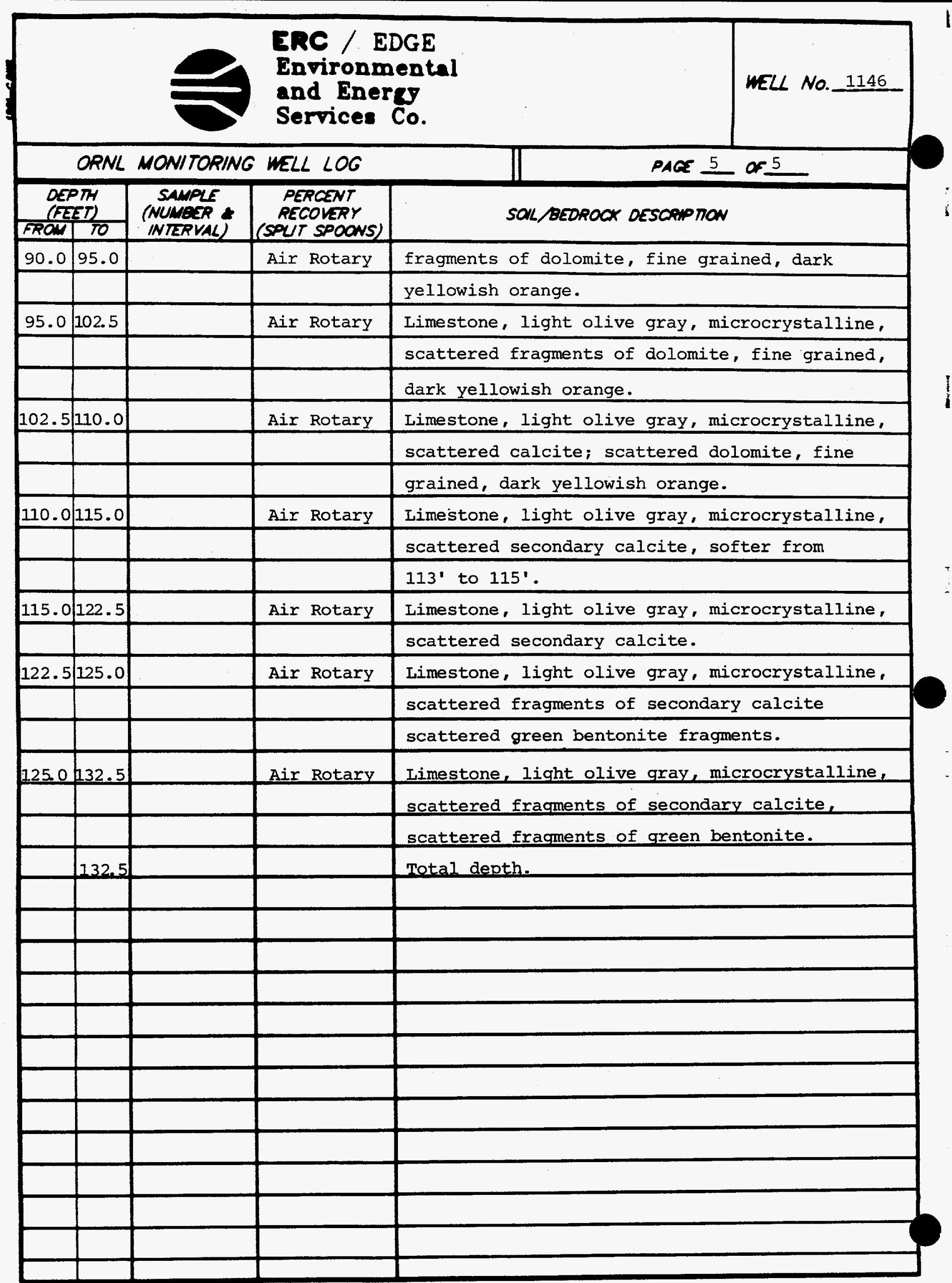




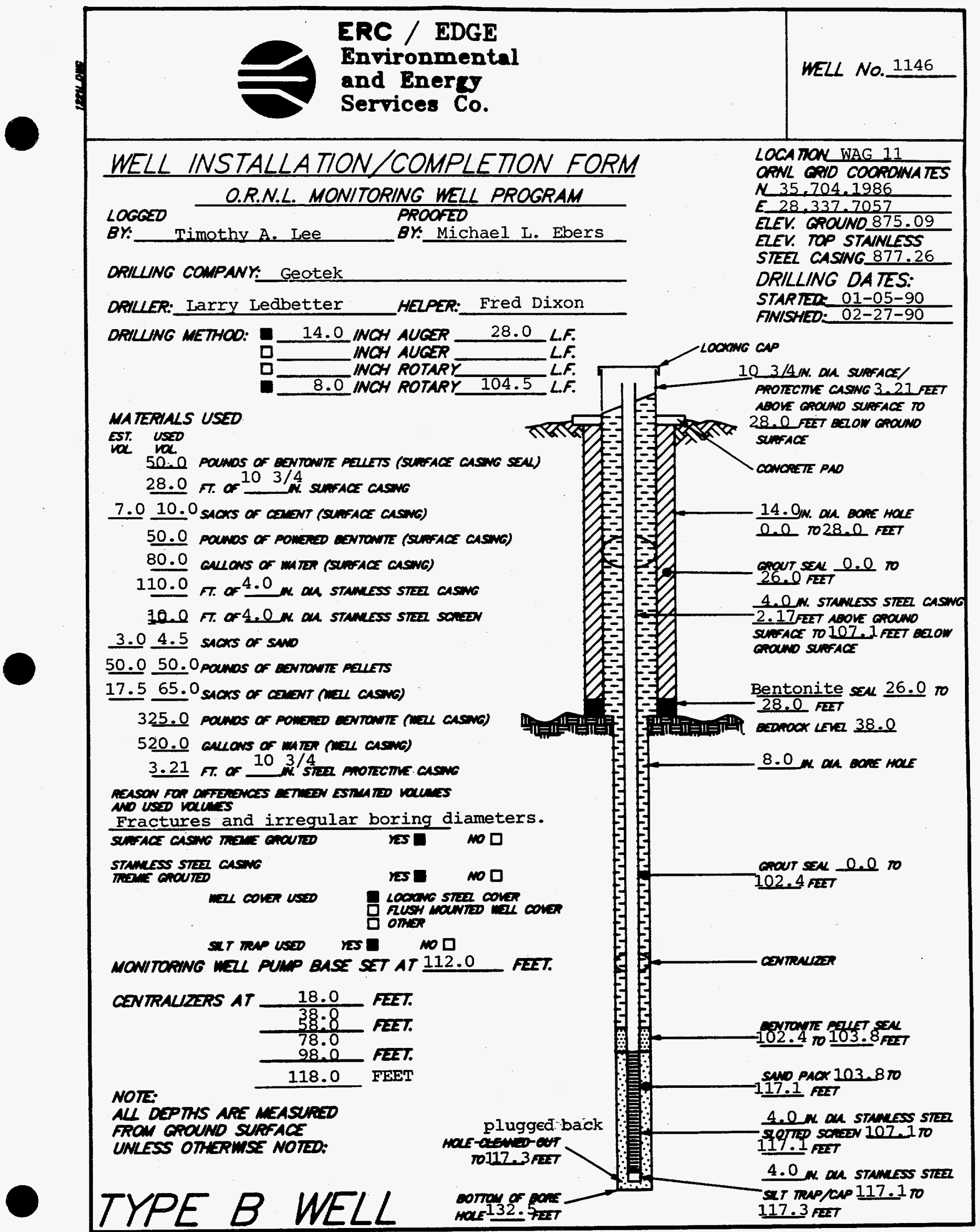

MATERIALS USED

EST. USED

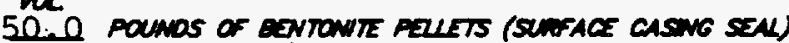

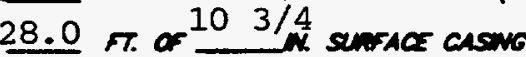

7.010 .0 suchs of canent (sumface caswo)

50.0 paunos of pomined aswrowre (senface caswo)

80.0 culews or miter (semorace caswa)

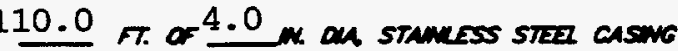

10.0 r. of 4.0 n. on stankess stez soned

3.04 .5 suars or sino

50.0 50.0 pounos of exvrowte peziets

17.565 .0 sucks of canent (uzz caswo)

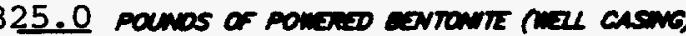

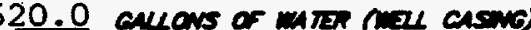

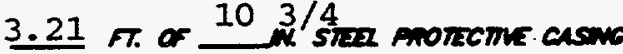

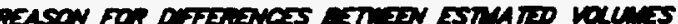

No used valuss

Fractures and irregular boring diameters.

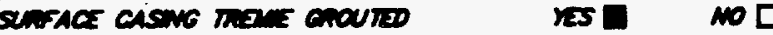

stamerss stez casevo

mest cover useo

Lacours 5737 const

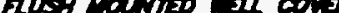

arrs?

IT

NONITORING "II PUNP BASE SET AT 112.0

FEIT.

ALI DSPTHS ARE MEASURED

FROW GROUNO SURFACE

UNEESS OTHERMSE NOTED.

TYPE $B$ WELL

Moxe $132.72 \pi$

PACE 15 or 24 
ERC / EDGE

Environmental

WELL No.1146

and Energy

Services Co.

DA TE: 02-27-90

\section{MONITORING WELL MATERIALS CERTIFICATION}

\begin{tabular}{|c|c|c|c|}
\hline ITEM/MA TERIAL & & DATE USED & BATCH NUMBER \\
\hline \multicolumn{2}{|l|}{ SAND } & $02-27-90$ & 2 \\
\hline \multirow{2}{*}{ BENTONITE } & Pellets & $01-08-90$ & 1 \\
\hline & Powder & $02-28-90$ & 5 \\
\hline STAINLESS STEEL SCREEN & $\left(\begin{array}{ll}\text { (PREPACKAGED } & \text { NES } \\
\text { NO }\end{array}\right)$ & $02-27-90$ & 3 \\
\hline STAINLESS STEEL CASING & (PREPACKAGED O NOS & $02-27-90$ & 3 \\
\hline STAINLESS STEEL CENTRALIZERS & $\left(\begin{array}{lll}\text { PREPACKAGED } & \text { GES } \\
\text { NO }\end{array}\right)$ & $02-27-90$ & 2 \\
\hline STAINLESS STEEL CAPS & $\left(\begin{array}{ll}\text { PREPACKAGED } & \text { VES } \\
\text { NO }\end{array}\right)$ & $02-27-90$ & 2 \\
\hline MONITORING WELL PUMP & $\left(\begin{array}{ll}\text { (PREPACKAGED } & \text { YES } \\
\text { NO }\end{array}\right)$ & $08-09-90$ & 8 \\
\hline \multirow{2}{*}{ GROUT } & Diverter & $01-08-90$ & 3 \\
\hline & Well Casing & $02-27-90$ & 6 \\
\hline \multicolumn{2}{|l|}{ WELL COVERS } & & \\
\hline \multicolumn{2}{|l|}{ SURFACE CASING/DIVERTER } & $01-08-90$ & 3 \\
\hline
\end{tabular}

COMMENTS:

OBSERVER SGNATURE OATE Sthuoth Th 02-27-90

PAGE 16 of 24 


\section{POST-WELL COMPLETION CHECKLIST}

\section{POST-WELL COMPLETION TASKS}

1. NUD SCRAPED FRON AUGERS, SMMPLERS, ANO ALL OTHER EOUIPMENT.

2. ALL WUO FRON ANG ANO EQUMPNENT SCRAPNGS ANO CUTINOS OSPOOSD OF IN ACCOROANCE WTH THE SPECAFCA MON PROWDED.

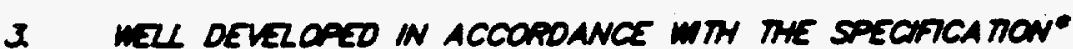

$08-09-90$ PROVIOED ANO DETAKS OF THE DEVEZOMENT ACTUTH RECOROED.

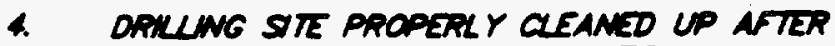
COMPLETION of nIL INSTALU HON.

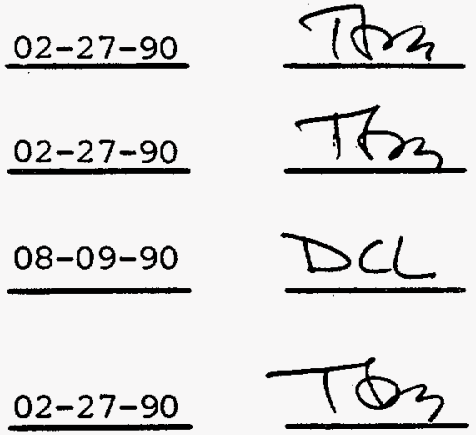

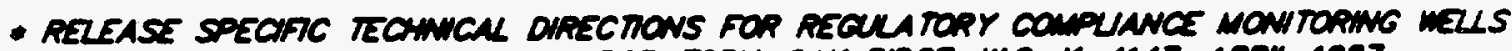
PHASE 1, OAK RIDCE NA TOWN LABOPATOPY, OAK RWDEE M. K-4147, APRK 1987.
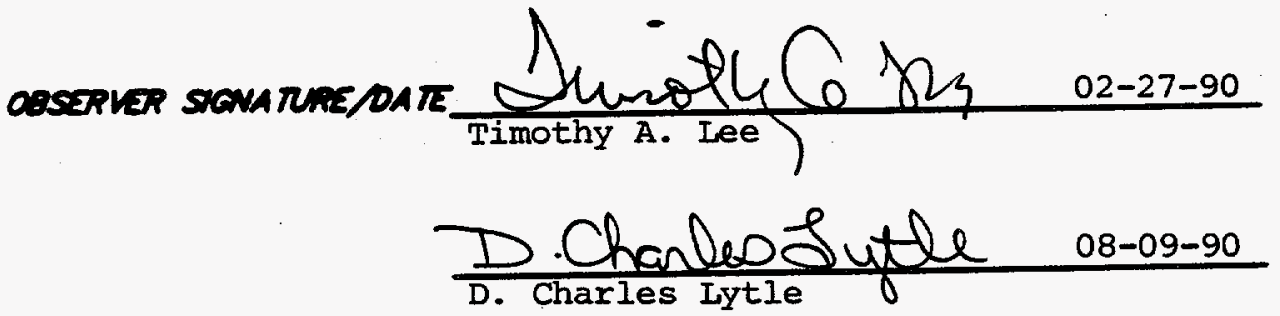


\section{MONITORING WELL DEVELOPMENT FORM}

DEVELOPMENT DETAILS

METHOO OF

DEVELPPMENT: Surging and Pumping

DEVELOPMENT

BEGAN DATE: $\quad 07-31-90$

TME:

DEVELOPMENT

ENDING DATE: 08-09-90

OEVELOPMENT

OBSERVED BY: D. Charles Iytle

ONE WELL VOLUME:_35.3_ GALLONS

TOTAL GALLONS PUMPED: 501 TOTAL WELL VOLUMES PUMPED: 14.2

INITAL PH: 8.7 FNAL PH: 8.6

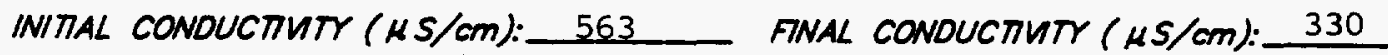

OESCRIPTION OF INITAL RURBIDITY: MuddY

DESCRIPTION OF FNAL RURBIDIT:_Clean

FNAL MEASURED TURBIDITY: $2.0 \mathrm{NTU}^{\prime} \mathrm{S}$

WELL APPROVED BY: R.C. WIIliams MMES

OOOR

QF WATER: None

WATER

DISCHARGED

TO:

GROUNO SURFACE

口 STORM SEWERS

D DRUMS
口 TANK TRUCK

口 STORAGE TANKS

口 OTHER

INITAL PRE-DEVELOPMENT

WA TER DEPTH: 79.4 feet from ground surface.

DEVELOPMENT OBSERVA TONS

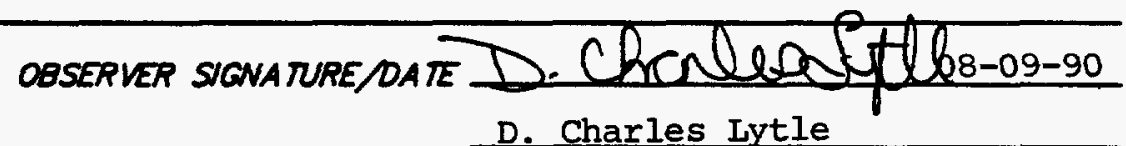




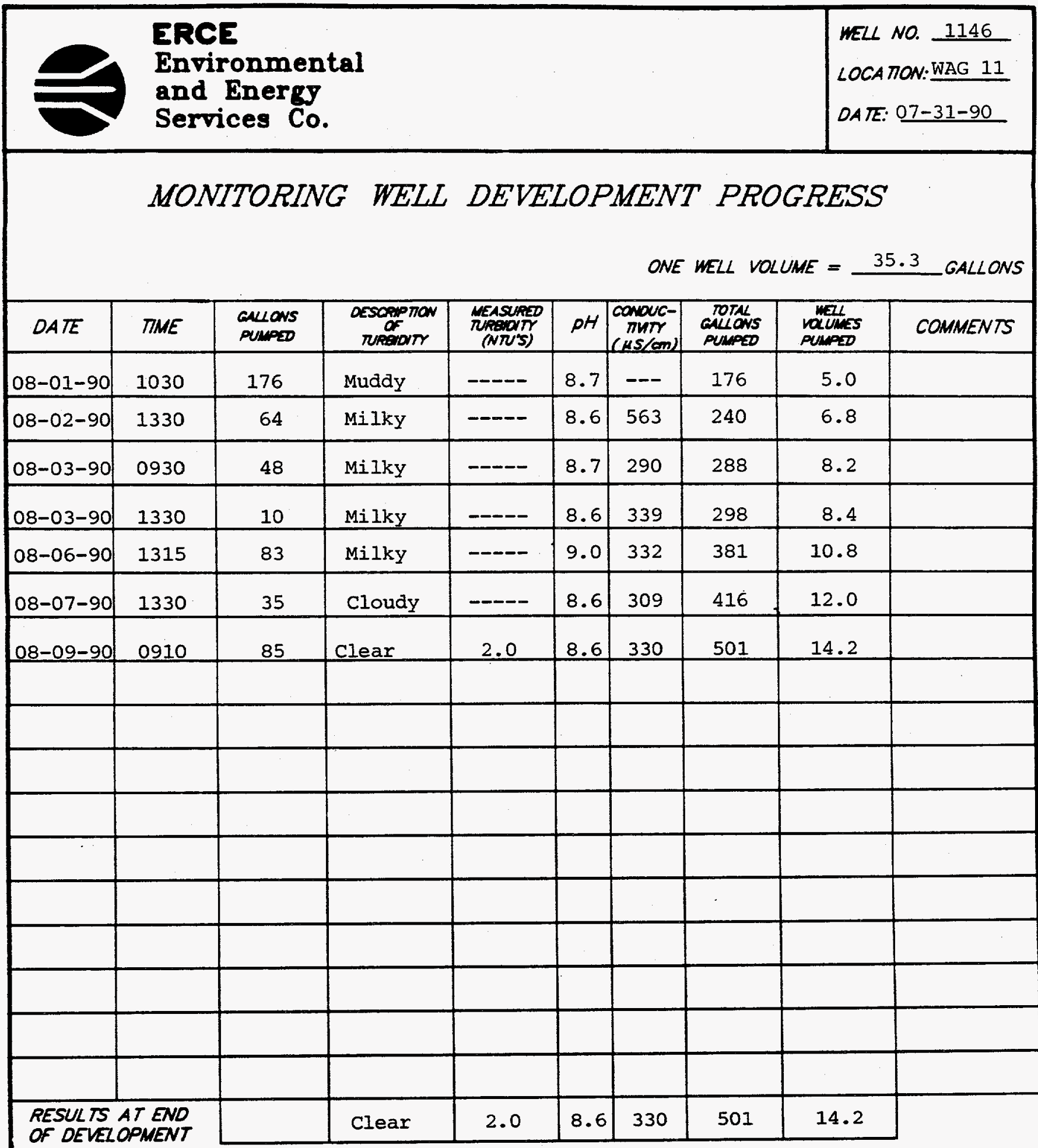

COMMENTS Good recharger and a good producer. Water cleaned to 2.0 NTU's and passed. Moved to next hole. 
ERC / EDGE

Environmental

and Energy

WELL NO. 1146

Services Co.

\section{HYDRAULIC CONDUCTIVTY CALCULATIONS}

PROGRAM SLUGT, VERSION 4.1, NOV. 1986

THIS PROGRAM CALCULATES MEAN TRANSMISSIVITIES FROM

SLUG-TEST DATA BASED ON TWO ANALYTICAL APPROACHES:

(1) METHOD OF COOPER, BREDEHOEFT AND PAPADOPULOS, 1967

(ARTICLE IN VOL.3, NO.1 OF WRR ENTITLED

"RESPONSE OF A FINITE DIAMETER WELL TO AN INSTANTANEOUS

CHARGE OF WATER")

(2) METHOD OF BOUWER AND RICE, 1976 (ARTICLE IN

VOL. 12, NO.3 OF WRR ENTITLED

"A SLUG TEST FOR DETERMINING HYDRAULIC CONDUCTIVITY

OF UNCONFINED AQUIFERS WITH COMPLETELY OR PARTIALLY

PENETRATING WELLS")

WELL NO.: 1146

DATE OF TEST: $9-21-90$

PROJECT NO.: E221-002

CLIENT: MMES

SITE LOCATION: WAG-11

EDGE, INC. FIELD INVESTIGATOR: JAMES W. CARUTHERS

INPUT DATA ARE:

INNER CASING DIAMETER $=4.00$ INCHES

INNER SCREEN OR OPEN-HOLE DIAMETER $=4.00$ INCHES

DIAMETER OF DRILLED HOLE $=8.00$ INCHES

LENGTH OF SCREEN OR INTAKE PORTION $=10.00$ FEET

DEPTH FROM STATIC LEVEL TO BOTTOM OF SCREEN $=34.72$ FEET

THICKNESS OF SATURATED AQUIFER ZONE $=10.00 \mathrm{FEET}$

DEPTH TO STATIC WATER LEVEL BELOW REF. POINT $=1.00$ FEET

ESTIMATED POROSITY OF GRAVEL PACK $=.20$

FALLING-HEAD INDEX $=1$ ("1" IF FALLING,"O" IF RISING)

NUMBER OF DEPTH-TIME DATA POINTS = 32

HO WAS COMPUTED FROM INTERCEPT OF PLOT OF LOG(H) VS. TIME

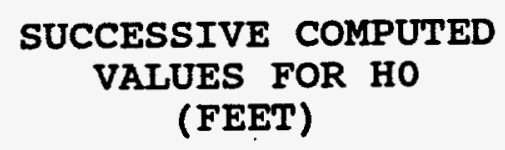

VALUES FOR HO

(FEET)

2.0339

2.0272 


\section{HYDRAULIC CONDUCTIVTY CALCULATIONS}

\begin{tabular}{|c|c|c|}
\hline$\left(\right.$ SEC $\left.^{\text {TIME }}\right)$ & $\begin{array}{l}\text { DEPTH TO WATER } \\
\text { (FEET) }\end{array}$ & $\begin{array}{r}\text { HEAD } \\
\text { (FEET) }\end{array}$ \\
\hline $\begin{array}{r}10.00 \\
20.00 \\
30.00 \\
40.00 \\
50.00 \\
60.00 \\
75.00 \\
90.00 \\
105.00 \\
120.00 \\
150.00 \\
180.00 \\
240.00 \\
300.00 \\
360.00 \\
420.00 \\
480.00\end{array}$ & $\begin{array}{l}3.060 \\
3.080 \\
3.060 \\
3.050 \\
3.040 \\
3.030 \\
3.010 \\
2.990 \\
2.950 \\
2.940 \\
2.880 \\
2.840 \\
2.730 \\
2.610 \\
2.540 \\
2.430 \\
2.360\end{array}$ & $\begin{array}{l}2.060 \\
2.080 \\
2.060 \\
2.050 \\
2.040 \\
2.030 \\
2.010 \\
1.990 \\
1.950 \\
1.940 \\
1.880 \\
1.840 \\
1.730 \\
1.610 \\
1.540 \\
1.430 \\
1.360\end{array}$ \\
\hline $\begin{array}{r}540.00 \\
600.00 \\
720.00 \\
840.00 \\
960.00 \\
1080.00 \\
1200.00 \\
1320.00 \\
1440.00 \\
1560.00 \\
1680.00 \\
1800.00 \\
1920.00 \\
2040.00 \\
2160.00\end{array}$ & $\begin{array}{l}2.260 \\
2.190 \\
2.060 \\
1.980 \\
1.890 \\
1.790 \\
1.740 \\
1.660 \\
1.580 \\
1.530 \\
1.640 \\
1.600 \\
1.550 \\
1.530 \\
1.360\end{array}$ & $\begin{array}{r}1.260 \\
1.190 \\
1.060 \\
.980 \\
.890 \\
.790 \\
.740 \\
.660 \\
.580 \\
.530 \\
.640 \\
.600 \\
.550 \\
.530 \\
.360\end{array}$ \\
\hline
\end{tabular}


ERC / EDGE

Environmental

WELL NO. 1146 and Energy

Services Co.

\section{HYDRAULIC CONDUCTIVTY CALCULATIONS}

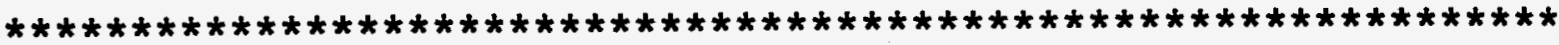

METHOD OF BOUWER AND RICE

COMPUTED RESULTS USING DIAMETER OF DRILLED HOLE:

PERMEABILITY $=3.47 \mathrm{E}-06 \mathrm{FT} / \mathrm{SEC} \quad=1.06 \mathrm{E}-04 \mathrm{CM} / \mathrm{SEC}$

TRANSMISSIVITY $=3.47 \mathrm{E}-05 \quad \mathrm{FT} * 2 / \mathrm{SEC}$

COMPUTED RESULTS USING DIAMETER OF CASING AND SCREEN:

$\begin{array}{ll}\text { PERMEABILITY }=4.11 \mathrm{E}-06 \mathrm{FT} / \mathrm{SEC} & =1.25 \mathrm{E}-04 \mathrm{CM} / \mathrm{SEC} \\ \text { TRANSMISSIVITY }=4.11 \mathrm{E}-05 \mathrm{FT} * * 2 / \mathrm{SEC} & \end{array}$


ERC / EDGE

Environmental

and Energy

WELL No. 1146

Services Co.

\section{HYORAULIC CONDUCTIUTY CALCULATIONS}

10.0
9.0

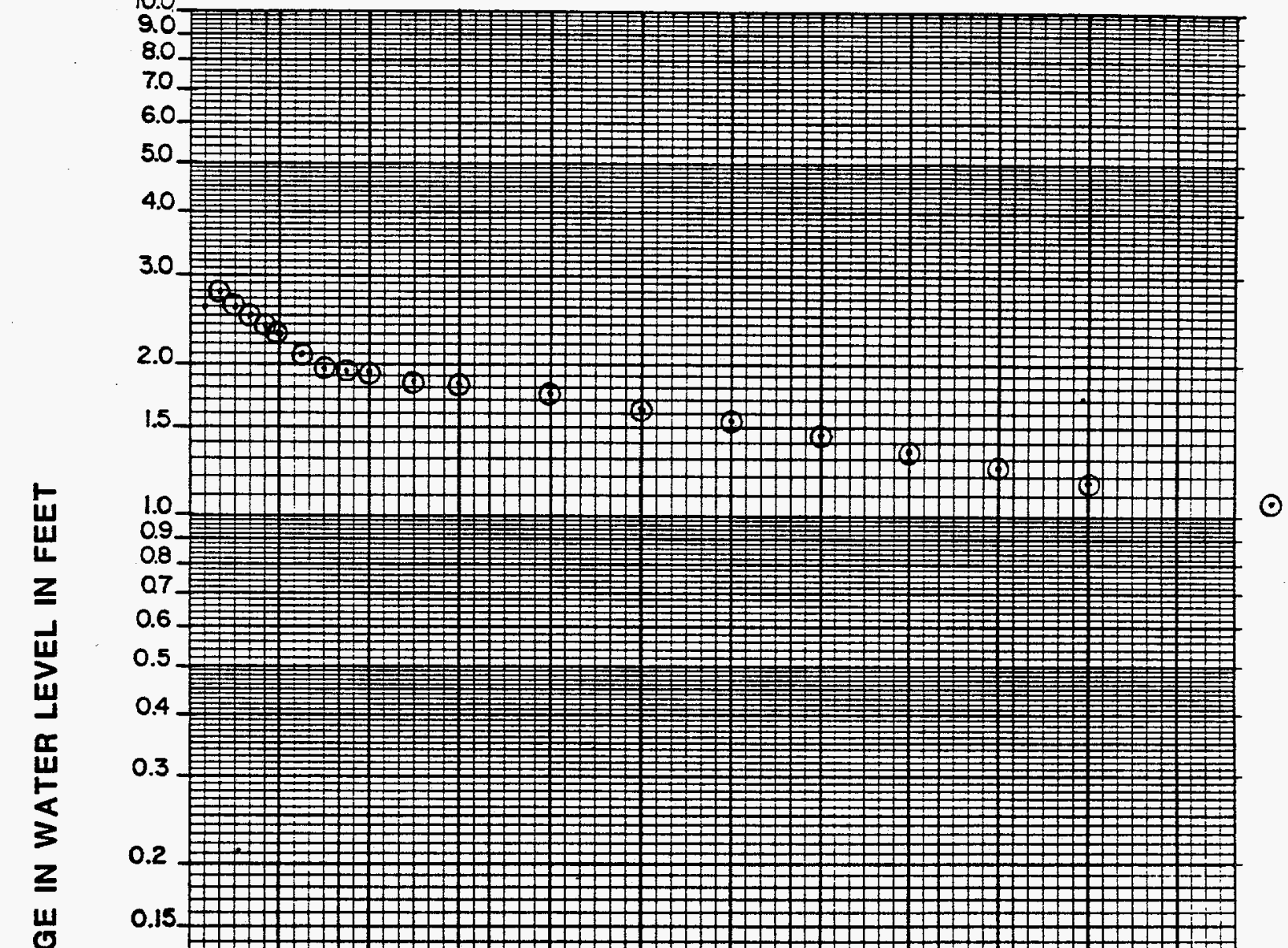

$\frac{1}{0}$

\subsection{8}

0.08

0.07

0.06

0.05

0.04

0.03

0.02

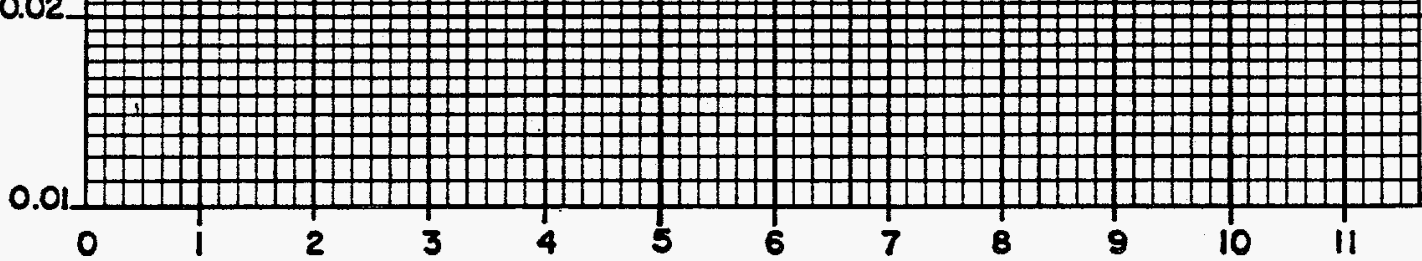

TIME IN MINUTES 


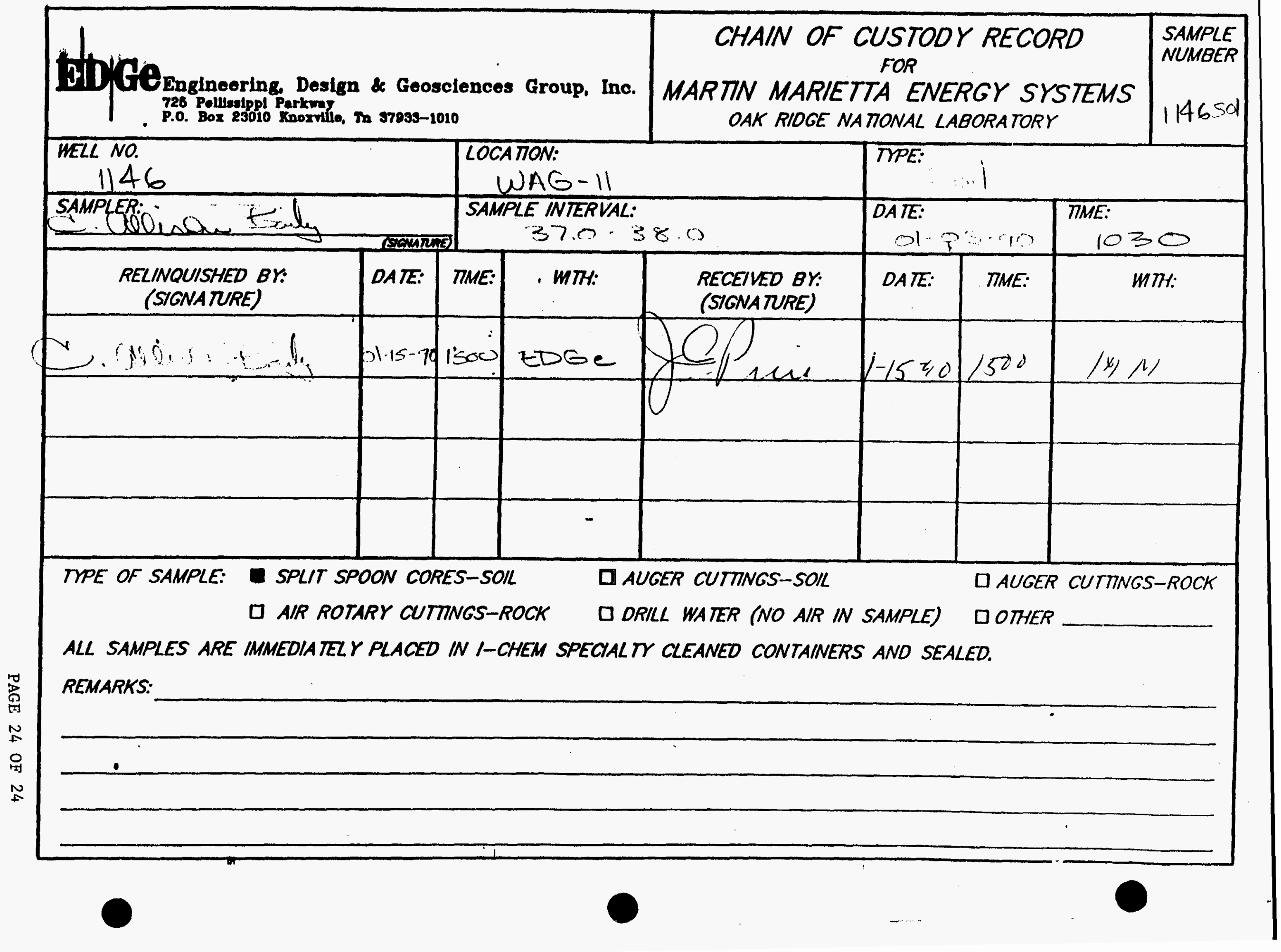




\subsection{General Information}

\subsection{Well Location}

Monitoring well number 1148 is located in WAG 11 . It is located in the southwest portion of White wing Scrap Yard. The location is shown on ORNL drawing number C3E20004A075. Survey coordinates for this well are N 35,000.4186, E 29,698.6994 (X-10 grid) or latitude $35^{\circ}-57^{\prime}-15.04^{\prime \prime}$ and longitude $84^{\circ}-20^{\prime}-42.18^{\prime \prime}$. Coordinate data were provided by Martin Marietta Energy Systems. The method used for conversion from $x-10$ grid to Tennessee-Lambert state Plane coordinates came from the publication "Tennessee Valley Authority Data Services Branch and Mapping Services Branch, Oak Ridge, Tennessee, DOE Plant Control, November 6, 1985, Field Book: ESS-3115, pp. 1-20." The latitude and longitude were calculated by Adams Craft Herz Walker Engineering, Inc., using methods from the U.S. Coast and Geodetic survey Publication 62-4, "State Plane Coordinates by Automatic Data Processing."

\subsection{Drilling Information}

Well number 1148 was drilled by Geotek Engineering Company. An Ingersoll Rand T-4 rig was used to drill this boring for monitor well installation under operation of Larry Ledbetter with the assistance of Fred Dixon. Drilling commenced on 1-16-90 and was finished on 3-1-90. Paragraph 2.4.1 includes a detailed discussion of the well installation and a well schematic is included on the well installation/completion form. A synopsis of the 
drilling activity follows. This information was typed directly from field notes and was edited only when necessary for clarification.

01-16-90 The rig was mobilized to the staked location and set up on plastic sheeting. Auger to 10.4 feet using a 14-inch auger. Set 10.4 feet of decontaminated 10 3/4-inch steel diverter casing and grouted surface.

02-14-90 Cut casing below ground level and plug well with cement due to crooked hole.

02-16-90 Auger to 6.0 feet using a 22-inch auger and grouted 6.0 feet of $15.3 / 4$-inch decontaminated steel diverter casing with 5 sacks cement.

02-21-90 Drill from 6.0 feet to 37.0 feet using a 14 $1 / 2$-inch air rotary tricone bit.

02-22-90 Set 36.8 feet of 10 3/4-inch decontaminated steel surface casing.

02-23-90 Grouted surface casing annulus with 16 sacks cement.

03-01-90 Drill to 67.5 feet using a 8.0-inch air ro ry tricone bit. Set 4-inch stainless steel well casing and screen with sand pack and bentonite seal.

03-02-90 Tremie grouted well casing annulus with 21 sacks cement with bentonite powder and flocele.

03-06-90 Tremie grouted to surface with 6 sacks cement with flocele.

Note: A stainless steel weighted tape broke and fell into hole at 49.6 feet. It was encapsula ed with bentonite pellets and grouted up. 
ERC / EDGE

Environmental

and Energy

Services Co.
MONITORING WELL PROGRAM

WELL DATA NARRATVE

WELL NO. 1148

This well was logged by ERC Environmental and Energy Services Co., Inc., hydrogeologist Timothy A. Lee. All well construction materials and supplies were from Martin Marietta Energy systems approved batches. The batch origin of individual items is shown on the included Monitoring Well Materials Certification form.

\subsection{Technical Information}

\subsection{Decontamination Procedures}

The drilling rig, down hole tools, surface casing, stainless steel screen, stainless steel casing, centralizers, and stainless steel silt trap underwent the cleaning decontamination procedures outlined in the drilling specifications (Release Specific Technical Directions for Regulatory Compliance Monitoring Wells Phase 1, Oak Ridge National Laboratory, Oak Ridge, w.o., K-4147, April 1987, pgs, 2-4). A checklist of the cleaned materials is included with this data package.

\subsection{Geology}

The northeastern half of WAG 11 is underlain by Chickamauga Limestone. The Rome Formation underlies the southwestern half of WAG 11. The Chickamauga Limestone is brought into contact with the Rome Formation by the White Oak Mountain thrust fault, the trace of which bisects WAG 11 from northwest to southeast. The lowermost beds of the Chickamauga are composed of thin bentonitic beds, gray clay shale, and maroon to gray calcareous siltstone. The majority of the chickamauga, approximately $1,500^{\prime}$ thick, is a dominantly gray, dense, finely crystalline, thin bedded limestone with varying 
amounts of chert. The uppermost beds consist of yellow and maroon calcareous siltstone and blue-gray limestone. The Rome Formation is composed of interbedded sandstone, siltstone, shale and locally, dolomite.

\subsection{Sample collection}

No soil samples were collected during drilling.

The Ingersoll Rand T-4 compressed air was sampled with a cloth filter inserted between drill rods on 3-1-90. The sample was examined with an ultraviolet light for the presence of hydrocarbons. The filter showed no detectable signs of hydrocarbons.

\subsection{Installation and Development}

\subsubsection{Installation}

This was a Type B well. A 22.0-inch diameter boring was augered from ground surface to 6.0 feet. A $153 / 4$-inch diverter casing was installed from surface to 6.0 feet below ground surface and grouted in place. The boring was then extended past the casing depth with a 14.0-inch air rotary tricone roller bit from 6.0 feet to 37.0 feet. A 10 3/4-inch diameter string of decontaminated steel surface casing was installed from 0.0 feet to 36.8 feet, sealed with a 2.0-foot bentonite pellet layer from 34.8 feet to 36.8 feet, and tremie grouted in place. The surface casing minimizes potential cross contamination between the regolith and bedrock water bearing zones. After the surface casing was installed, the air rotary method was used to drill an 8-inch diameter boring to a total depth of 67.5 feet. A 4-inch diameter stainless 
steel screen with threaded bottom cap was installed from 52.2 feet to 67.5 feet. A 4-inch diameter stainless steel casing was installed from the top of the screen at 52.2 feet and extended 2.8 feet above ground surface. A sandpack was then tremied into the annular space from 49.6 to 67.5 feet, with a 2.1-foot bentonite pellet seal poured into the annular space above the sandpack from 47.5 to 49.6 feet. The annular space from the top of the bentonite seal to the surface was tremie grouted with a cement/bentonite slurry. A detailed schematic of the well is included on the well installation/completion form.

\subsubsection{Well Development}

Well number 1148 was developed to remove drill cuttings, silt, and other fines. The monitoring was developed using a Geoguard pump with an air compressor. All pumps were cleaned prior to use according to specified cleaning procedures (see Paragraph 2.1). The well was developed until a measured total of 207 gallons of water had been evacuated and the clarity of the discharge water was approved by the company representative. The final turbidity value measured at completion was 2.0 NTU's. A development form showing the exact method of development and other pertinent data is appended.

2.4.3 Installation of Dedicated Monitoring Well Pump

After the well was developed, a Geoguard Model No. 5614 dedicated monitoring well pump was installed on $7 / 30 / 90$ at a depth of 65.8 feet below ground surface. These 
ERC / EDGE

Environmental

and Energy

Services Co.

pumps are decontaminated at American sigma and are sent prepackaged. A copy of the pump certification is kept on file at ORNL.

\subsection{Hydraulic Conductivity Testing}

Well number 1148 was tested for the determination of hydraulic conductivity of the aquifer in the vicinity of the well screen. This was accomplished by instantaneously adding a known quantity of water to the monitoring well and measuring the recovery of the water level over time. The changing water levels were measured using a Druck 15 psig pressure transducer and an Omnidata Datapod II data recorder. The hydraulic conductivity value of $1.40 \times 10^{-4} \mathrm{~cm} / \mathrm{second}$ (shown as permeability on the hydraulic conductivity calculations printout attached) was calculated using the Bouwer and Rice method. A computer printout of the hydraulic conductivity calculations is included in this data package. 


\section{PRE-DRILLING CHECKLIST FOR MONITORING WELLS}

PRE-DRILUNG TASKS

1. EXCAVTION PERMIT OBTAINED

2. ALL EQUIPMENT HAS BEEN CLEANED BEFORE DRILLING.

30. SCREEN AND CASING HAVE BEEN WASHED, STEAMED, RINSED WTH DE-IONIZED OR DISTILED WATER, RINSED WTH ISOPROPN ALCOHOL, WRAPPED WTH PROTECTVE COVERING AND STORED OFF THE GROUND.

36. PRE-PACKAGED SCREENS, CASING AND CENTRALIZERS WERE USED.

4. WORK AREA FOR SAMPLE EXAMINATION COVERED WTH CLEAN POL RETHRENE.

5. CLEAN KNIVES, GLOVES, SAMPLE JARS AND LABELS ON HAND.

6. POL YETHKENE COVER IN PLACE OVER HOLE.

7. AIR ROTARY COMPRESSED AIR SAMPLED.
COMPLIANCE
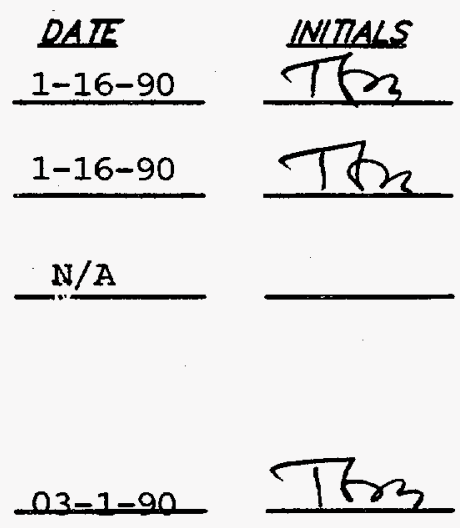

$01-16-90$

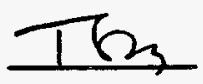

01-16-90

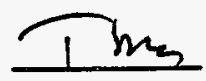

$\underline{01-16-90}$

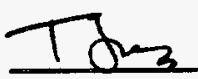

RESUL TS:

ADDITONAL NOTES/OBSERVATONS:

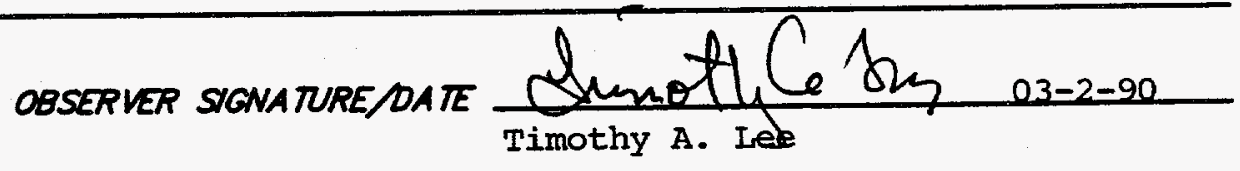


ERC / EDGE

Environmental

and Energy

WELL NO. 1148

Services Co.

$\frac{\text { DECONTAMINATION CHECKLIST }}{\text { DRILLING EQUIPMENT }}$

\begin{tabular}{|c|c|c|c|c|c|}
\hline EQUIPMENT & SCRAPE & $\begin{array}{l}\text { STEAN } \\
\text { CLEAN }\end{array}$ & $\begin{array}{l}\text { STEAM } \\
\text { RINSE }\end{array}$ & $\begin{array}{c}\text { ISOPROPYL } \\
\text { ALCOHOL } \\
\text { RINSE }\end{array}$ & $\begin{array}{c}\text { OEIONIZED } \\
\text { WATER } \\
\text { RINSE }\end{array}$ \\
\hline$R / G$ & $\mathrm{X}$ & $\mathrm{x}$ & $\mathrm{x}$ & $N / A$ & $N / A$ \\
\hline AUGERS & $x$ & $\mathrm{x}$ & $\mathrm{X}$ & $\mathrm{X}$ & $x$ \\
\hline BITS & $\mathrm{x}$ & $\mathrm{x}$ & $\mathrm{x}$ & $\mathrm{x}$ & $\mathrm{x}$ \\
\hline RODS & $\mathrm{x}$ & $\mathrm{x}$ & $\mathrm{x}$ & $\mathrm{x}$ & $\mathrm{x}$ \\
\hline SAMPLERS & $\mathrm{x}$ & $\mathrm{x}$ & $\mathrm{x}$ & $\mathrm{x}$ & $\mathrm{x}$ \\
\hline PIPES & $\mathrm{x}$ & $\mathrm{x}$ & $\mathrm{x}$ & $\mathrm{x}$ & $\mathrm{x}$ \\
\hline WORK TOOLS & $\mathrm{x}$ & $\mathrm{x}$ & $\mathrm{x}$ & $\mathrm{x}$ & $\mathrm{x}$ \\
\hline AUGER PINS & $\mathrm{x}$ & $\mathrm{x}$ & $\mathrm{x}$ & $\mathrm{x}$ & $\mathrm{X}$ \\
\hline & & & & 3 & \\
\hline & & & & & \\
\hline & & & & & \\
\hline & & & & & \\
\hline
\end{tabular}

OBSERVER SIGNATURE/DATE $\frac{\text { Ahmoth }}{\text { Timothy A. Iee }}$ 


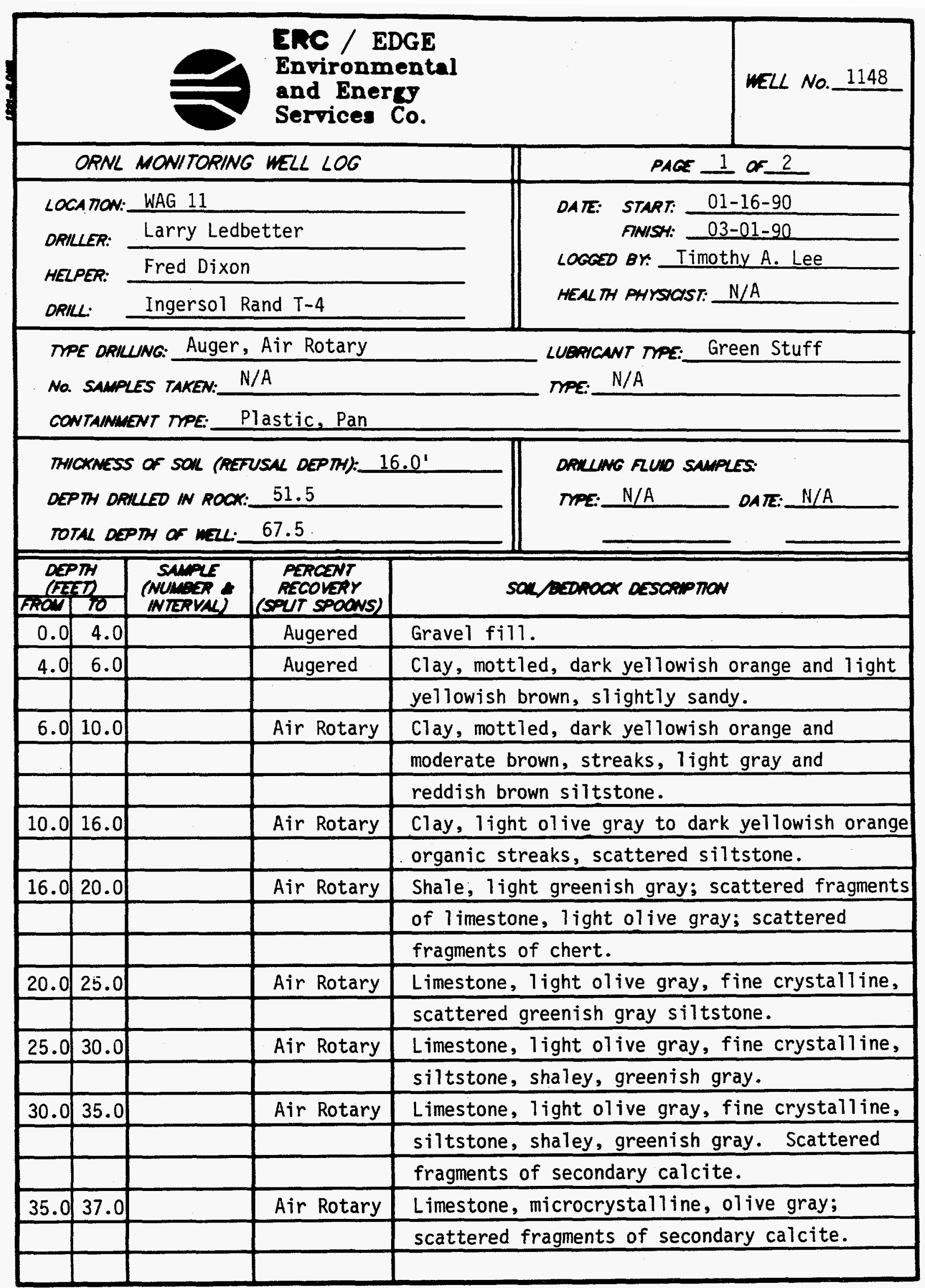




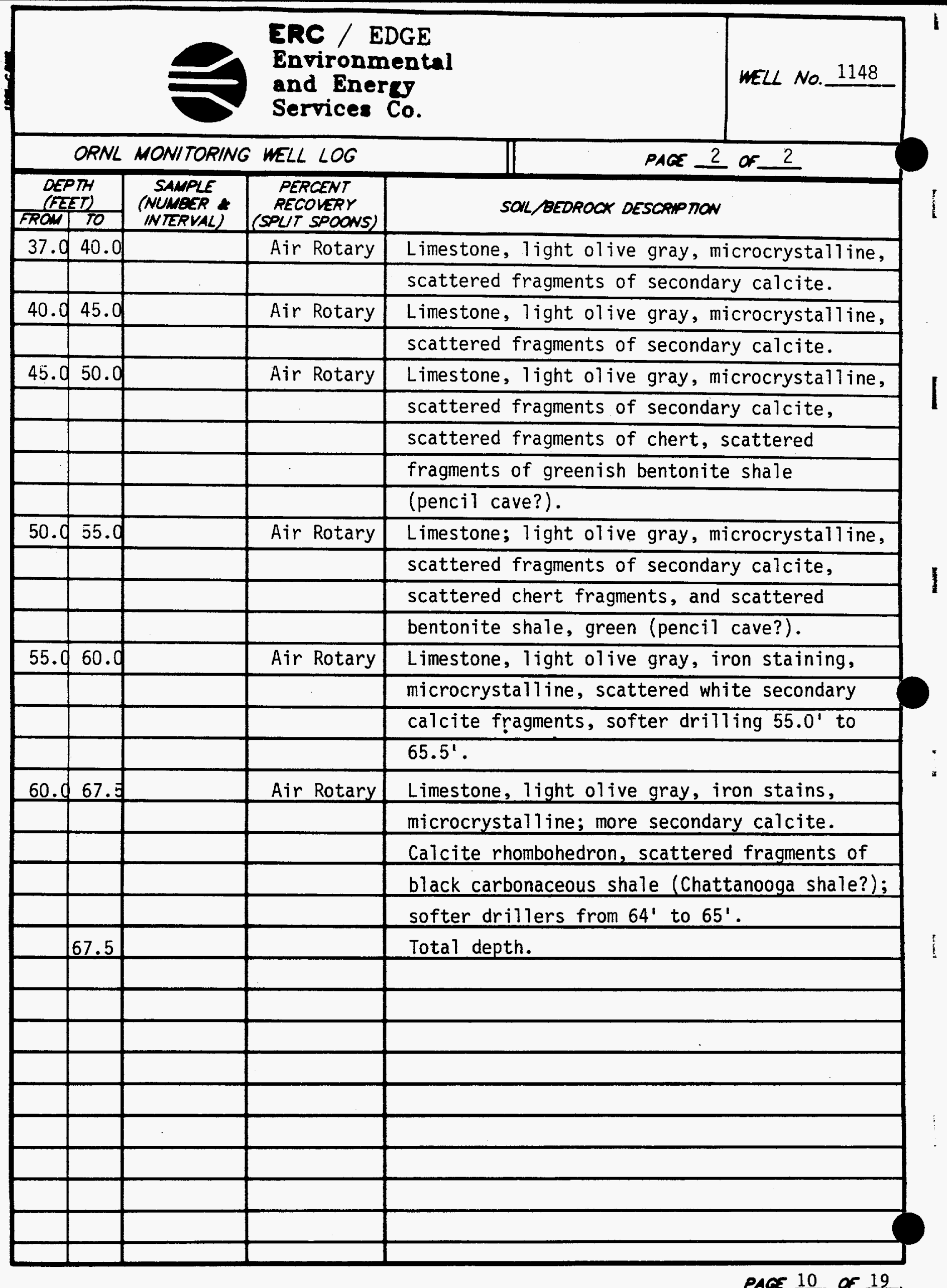




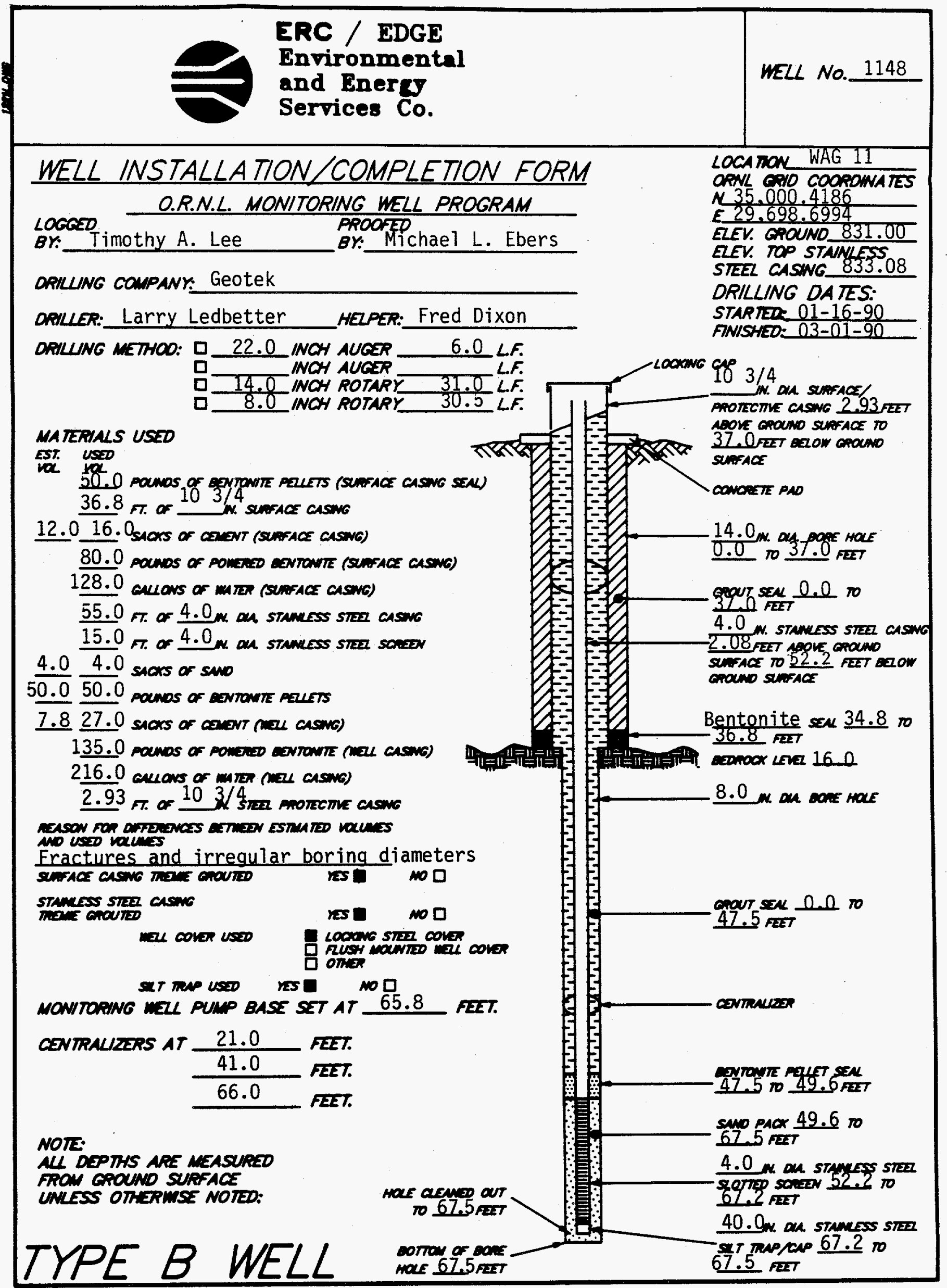

PACE 11 or 12 


\section{MONITORING WELL MATERIALS CERTIFICATION}

\begin{tabular}{|c|c|c|c|}
\hline ITEM/MA TERIAL & & DAIE USED & BATCH NUMEER \\
\hline \multicolumn{2}{|l|}{ SAND } & $03-01-90$ & 3 \\
\hline \multirow{2}{*}{ BENTONITE } & Pellets & $03-01-90$ & 1 \\
\hline & Powder & $03-02-90$ & 6 \\
\hline STAINLESS STEEL SCREEN & $\left(\begin{array}{ll}\text { PREPACKAGED } & \text { VES } \\
\text { NO }\end{array}\right)$ & $03-01-90$ & 3 \\
\hline STAINLESS STEEL CASING & $\left(\begin{array}{ll}\text { (PREPACKAGED } & \text { YES } \\
\text { NO }\end{array}\right)$ & $03-01-90$ & 3 \\
\hline STAINLESS STEEL CENTRALIZERS & $\left(\begin{array}{ll}\text { PREPACKAGED } & \text { YES } \\
\text { NO }\end{array}\right)$ & $03-01-90$ & 2 \\
\hline STAINLESS STEEL CAPS & $\left(\begin{array}{ll}\text { PREPACKAGED } & \text { TES } \\
\text { NO }\end{array}\right)$ & $03-01-90$ & 2 \\
\hline MONITORING WELL PUMP & $\left(\begin{array}{cc}\text { (PREPACKAGED } & \text { YES } \\
\text { NO }\end{array}\right)$ & $07-30-90$ & 8 \\
\hline \multirow{2}{*}{ GROUT } & \multirow{2}{*}{$\begin{array}{l}\text { Surface Casing } \\
\text { Well Casing }\end{array}$} & $02-23-90$ & 6 \\
\hline & & $03-02-90$ & 6 \\
\hline \multicolumn{4}{|l|}{ WELL COVERS } \\
\hline SURFACE CASING & & $02-22-90$ & 4 \\
\hline
\end{tabular}

COMMENTS:

OBSERVER SIGNATURE DATE $\frac{\mathrm{f} \text { tmothC. Jus 03-02-90 }}{\text { Timothy A. Lee) }}$ 
ERC / EDGE

Environmental

and Enerey

Services Co.

\section{POST-WELL COMPLETION CHECKLIST}

\section{ROST-MELL COMPLETON TASKS}

1. WO SCRAPED FRON AUGERS SMMPLERS ANO AL OTHER EOUIPMENT.

2. ALL WUD FRON ANG AND EQUPMENT SORAPWOS ANO CUTINOS OISPOSED OF IN ACCOPDANCE WIH THE secarich now" PRowozo.

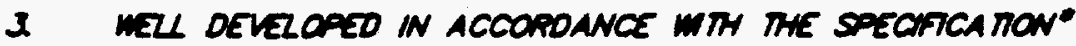
PROMOCO ANO OETALS OF THE OEVZZOPMENT ACTUT RECONOED.

4. DRWLNG STE PROPERTY CLEAMED UP AFTER CONPLETION of inzl INSTALLA ION.

$03-02-90$

$16 n_{1}$

$03-02-90$

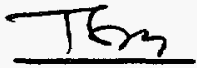

$07-30-90$

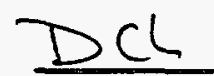

$03-02-90$

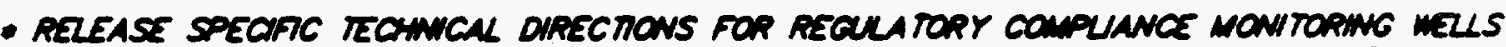

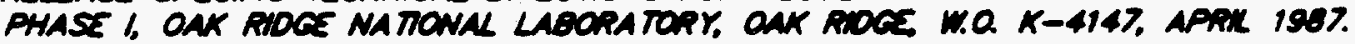

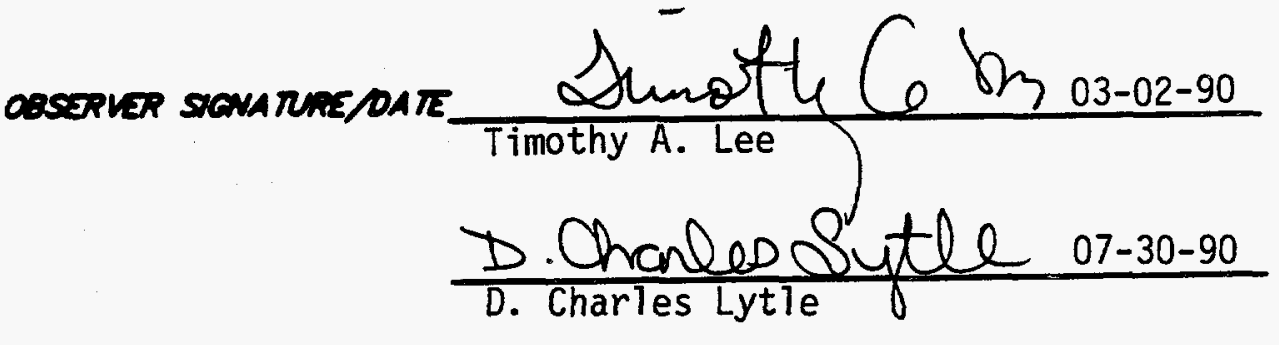




\section{MONITORING WELL \\ DEVELOPMENT FORM}

DEVELOPMENT DETAILS

METHOD OF
DEVELOPMENT: Surging and Pumping

DEVELOPMENT

BEGAN DATE: $\quad 07-30-90$

TME:

DEVELOPMENT

ENDING DATE:

$07-30-90$

DEVELOPMENT

OBSERVED BY: D. Charles Lytle

ONE WELL VOLUME: 16.3 GALLONS

TOTAL GALLONS PUMPED: 207 TOTAL WELL VOLUMES PUMPED: 12.7

INITAL PH: 8.7 FNAL PH: 8.7

INITAL CONOUCTUTY (KS/Cm): 598 FNAL CONOUCTUTH ( $\mathrm{HS} / \mathrm{cm}$ ): 598

OESCRIPTION OF INITAL TURBIOITY: Clear

DESCRIPTON OF FNAL TURBIOITY: Clear

FNAL MEASURED TURBIDITY: 2.0

WELL APPROVED BY: R.C. Will iams MMES

ODOR

OF WATER: None

WA TER

OISCHAREED

GROUNO SURFACE

口 STORM SEWERS

D DRUNS

口 TANK TRUCK

口 STORACE TANKS

TO:

$\square$ OTHER

INITAL PRE-DEVELOPNENT

WATER DEPTH: 9.5 feet from ground surface.

DEVELOPMENT OBSERVATIONS

OBSERVER SIGNATURE PATE D. Chonleesf fotle 07-30-90 


\section{MONITORING WELL DEVELOPMENT PROGRESS}

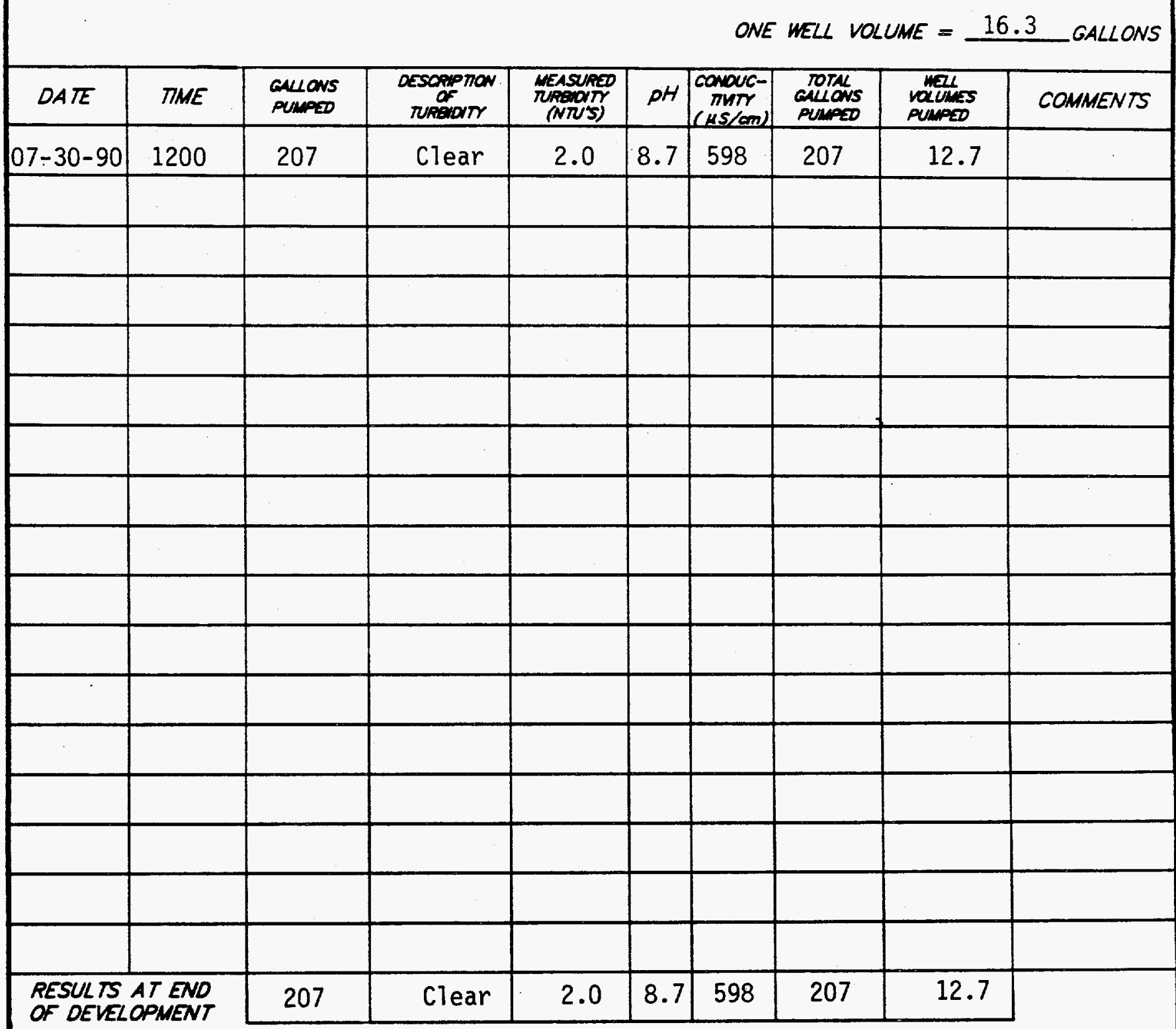

COMMENTS Fast recharger, made a lot of water in a short time. Passed with 2.0 NTU's and moved to another hole. 


\section{HYDRAULIC CONDUCTIVTY CALCULATIONS}

PROGRAM SLUGT, VERSION 4.1, NOV. 1986

THIS PROGRAM CALCULATES MEAN TRANSMISSIVITIES FROM SLUG-TEST DATA BASED ON TWO ANALYTICAL APPROACHES :

(1) METHOD OF COOPER, BREDEHOEFT AND PAPADOPULOS, 1967 (ARTICLE IN VOL.3, NO.1 OF WRR ENTITLED "RESPONSE OF A FINITE DIAMETER WELL TO AN INSTANTANEOUS CHARGE OF WATER")

(2) METHOD OF BOUWER AND RICE, 1976 (ARTICLE IN VOL. 12, NO.3 OF WRR ENTITLED

"A SLUG TEST FOR DETERMINING HYDRAULIC CONDUCTIVITY OF UNCONFINED AQUIFERS WITH COMPLETELY OR PARTIALLY PENETRATING WELLS")

WELL NO.: 1148

DATE OF TEST: $9-14-90$

PROJECT NO.: E221-002

CLIENT: MMES

SITE LOCATION: WAG-11

EDGE, INC. FIELD INVESTIGATOR: JAMES W. CARUTHERS

\section{INPUT DATA ARE:}

INNER CASING DIAMETER $=4.00$ INCHES INNER SCREEN OR OPEN-HOLE DIAMETER = 4.00 INCHES DIAMETER OF DRILLED HOLE $=8.00$ INCHES LENGTH OF SCREEN OR INTAKE PORTION $=15.00$ FEET DEPTH FROM STATIC LEVEL TO BOTTOM OF SCREEN $=59.77$ FEET THICKNESS OF SATURATED AQUIFER ZONE $=15.00$ FEET DEPTH TO STATIC WATER LEVEL BELOW REF. POINT $=1.00$ FEET ESTIMATED POROSITY OF GRAVEL PACK $=.20$

FALLING-HEAD INDEX $=1$ ("I" IF FALLING,"0" IF RISING) NUMBER OF DEPTH-TIME DATA POINTS = 32

HO WAS COMPUTED FROM INTERCEPT OF PLOT OF LOG(H) VS. TIME SUCCESSIVE COMPUTED

VALUES FOR HO

(FEET)

.4642

.4751 


\section{HYDRAULIC CONDUCTIVTY CALCULATIONS}

\begin{tabular}{|c|c|c|}
\hline$\left(S E C^{\text {TIME }}\right)$ & $\begin{array}{l}\text { DEPTH TO WATER } \\
\text { (FEET) }\end{array}$ & $\begin{array}{l}\text { HEAD } \\
\text { (FEET) }\end{array}$ \\
\hline $\begin{array}{r}10.00 \\
20.00 \\
30.00 \\
40.00 \\
50.00 \\
60.00 \\
75.00 \\
90.00 \\
105.00 \\
120.00 \\
150.00 \\
180.00 \\
240.00 \\
300.00 \\
360.00 \\
420.00 \\
480.00\end{array}$ & $\begin{array}{l}2.710 \\
2.260 \\
2.050 \\
1.860 \\
1.760 \\
1.650 \\
1.570 \\
1.510 \\
1.430 \\
1.390 \\
1.320 \\
1.260 \\
1.200 \\
1.170 \\
1.150 \\
1.120 \\
1.130\end{array}$ & $\begin{array}{r}1.710 \\
1.260 \\
1.050 \\
.860 \\
.760 \\
.650 \\
.570 \\
.510 \\
.430 \\
.390 \\
.320 \\
.260 \\
.200 \\
.170 \\
.150 \\
.120 \\
.130\end{array}$ \\
\hline $\begin{array}{r}540.00 \\
600.00 \\
720.00 \\
840.00 \\
960.00 \\
1080.00 \\
1200.00 \\
1320.00 \\
1440.00 \\
1560.00 \\
1680.00 \\
1800.00 \\
1920.00 \\
2040.00 \\
2160.00\end{array}$ & $\begin{array}{l}1.130 \\
1.100 \\
1.100 \\
1.080 \\
1.100 \\
1.070 \\
1.080 \\
1.070 \\
1.070 \\
1.180 \\
1.060 \\
1.060 \\
1.060 \\
1.040 \\
1.050\end{array}$ & $\begin{array}{l}.130 \\
.100 \\
.100 \\
.080 \\
.100 \\
.070 \\
.080 \\
.070 \\
.070 \\
.180 \\
.060 \\
.060 \\
.060 \\
.040 \\
.050\end{array}$ \\
\hline
\end{tabular}




\title{
HYORAULIC CONDUCTIVTY CALCULATIONS
}

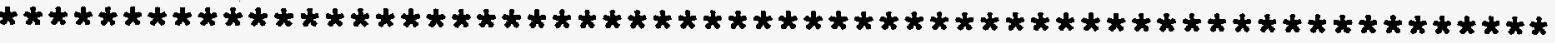

METHOD OF BOUWER AND RICE

COMPUTED RESULTS USING DIAMETER OF DRILLED HOLE:

PERMEABILITY $=4.60 \mathrm{E}-06 \mathrm{FT} / \mathrm{SEC} \quad=\quad 1.40 \mathrm{E}-04 \mathrm{CM} / \mathrm{SEC}$

TRANSMISSIVITY $=6.91 \mathrm{E}-05 \mathrm{FT} * * 2 / \mathrm{SEC}$
\end{abstract}

COMPUTED RESULTS USING DIAMETER OF CASING AND SCREEN:

$$
\text { PERMEABILITY }=5.36 \mathrm{E}-06 \mathrm{FT} / \mathrm{SEC} \quad=1.63 \mathrm{E}-04 \mathrm{CM} / \mathrm{SEC}
$$

TRANSMISSIVITY $=8.04 \mathrm{E}-05 \quad \mathrm{FT} * * 2 / \mathrm{SEC}$ 
ERC / EDGE

Environmental

and Energy

WELL NO. 1148

Services Co.

\section{HYDRAULIC CONDUCTVTY CALCULATIONS}

10.0

9.0工

8.0

7.0

6.0

5.0

4.0

3.0

2.0

1.5

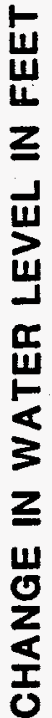

0.1

0.08

0.07

0.05

0.04

0.03

0.02

11212

$$
1+1+1+1212
$$

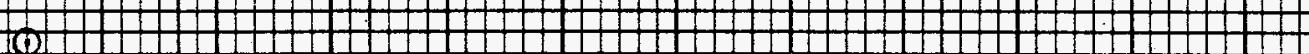

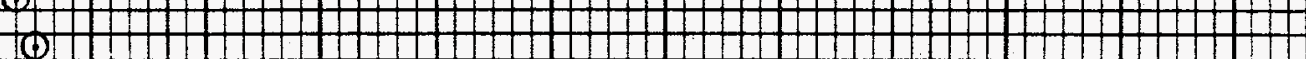

1

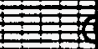

1

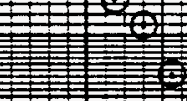

12

10

1

I
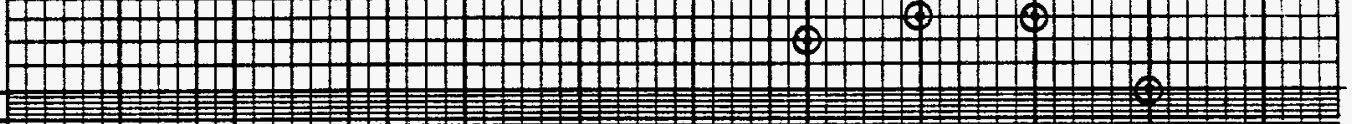

$+$

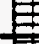
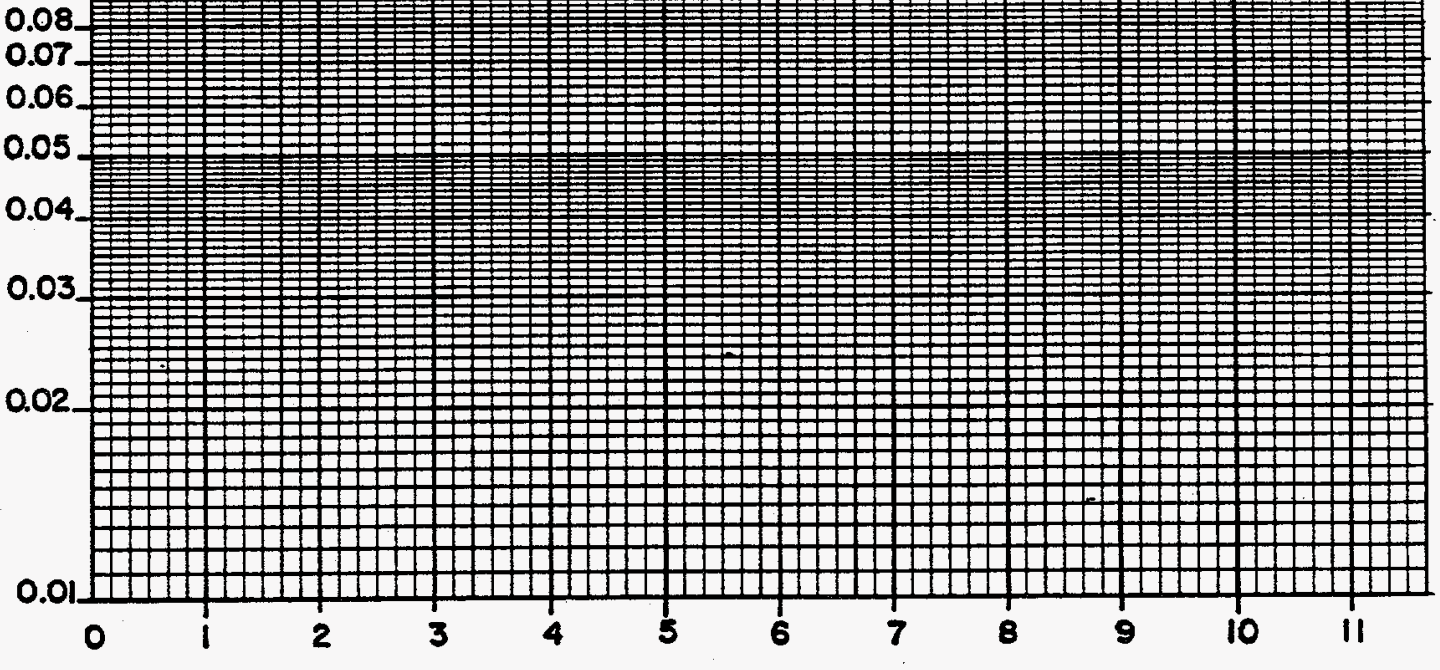

TIME IN MINUTES 
ERC / EDGE

Environmental

and Energy

Services Co.

1.0 General Information

\subsection{Well Iocation}

Monitoring well number 1246 is located in WAG 11. It is located on the western boundary of White wing scrap Yard. The location is shown on ORNL drawing number C3E20004A075. Survey coordinates for this well are N 35,090.0576, E 27,507.5298 (X-10 grid) or latitude $35^{\circ}-57^{\prime}-03.51^{\prime \prime}$ and longitude $84^{\circ}-21^{\prime}-05.21^{\prime \prime}$. Coordinate data were provided by Martin Marietta Energy systems. The method used for conversion from $\mathrm{x}-10$ grid to Tennessee-Lambert state Plane Coordinates came from the publication "Tennessee Valley Authority Data Services Branch and Mapping Services Branch, Oak Ridge, Tennessee, DOE Plant Control, November 6, 1985, Field Book: ESS-3115, pp. 1-20." The latitude and longitude were calculated by Adams Craft Herz Walker Engineering, Inc., using methods from the U.S. Coast and Geodetic Survey Publication 62-4, "State Plane Coordinates by Automatic Data Processing."

\subsection{Drilling Information}

Well number 1246 was arilled by Geotek Engineering Company. A Ingersoll Rand rig was used to drill this boring for monitor well installation under the operation of Larry Ledbetter with the assistance of Fred Dixon. Drilling commenced on 1-23-90 and was finished on 3-6-90. Paragraph 2.4.1 includes a detailed discussion of the well installation and a well schematic is included on the well installation/ completion form. A synopsis of the drilling activity follows. This information was typed directly from 


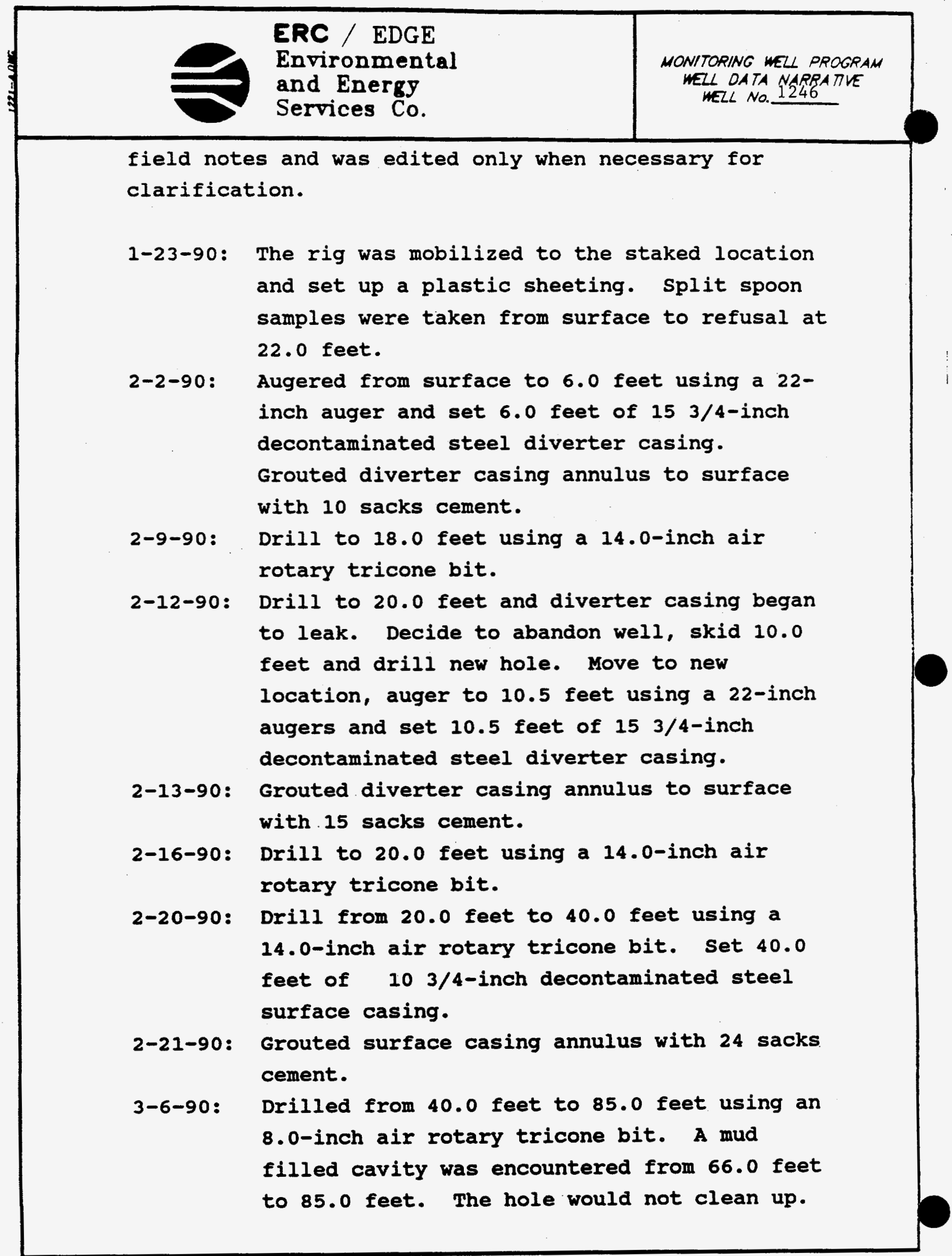


ERC / EDGE

Environmental

and Energy

Services Co.

9-20-90: Decontaminated drill rig, tools, and 100 feet of 8-inch hollow stem augers.

9-21-90: Mobilized rig to location and set up. Ran in 55 feet of 8-inch hollow stem augers.

9-24-90: Ran in 8-inch hollow stem augers to 85.5

feet. Auger refusal at 85.5 feet. Ran in 85 feet of AW drill rods and punched out stainless steel plug. Ran in 2-inch stainless steel screen and casing. Tremied in 12 sacks of sand through hollow stem augers.

9-25-90: Checked top of sand. Had dropped 2 feet overnight so tremied in one more sack of sand. Grouted annular space with two sacks of cement.

9-26-90: Finished grouting annular space with 19 sacks of cement.

This well was logged by ERC Environmental and Energy Services Co., Inc., hydrogeologist Bruce McMaster, Timothy A. Lee and Michael L. Ebers. All well construction materials and supplies were from Martin Marietta Energy Systems approved batches. The batch origin of individual items is shown on the included Monitoring Well Materials Certification form.

\subsection{Technical Information}

\subsection{Decontamination Procedures}

The drilling rig, down hole tools, surface casing, stainless steel screen, stainless steel casing, centralizers, and stainless steel silt trap underwent the cleaning decontamination procedures outlined in the 
drilling specifications (Release Specific Technical Directions for Regulatory Compliance Monitoring Wells Phase 1, Oak Ridge National Laboratory, Oak Ridge, W.O., K-4147, April 1987, pgs, 2-4). A checklist of the cleaned materials is included with this data package.

\subsection{Geology}

The northeastern half of WAG 11 is underlain by Chickamauga Limestone. The Rom Formation underlies the southwestern half of WAG 11. The Chickamauga Limestone is brought into contact with the Rome Formation by the White Oak Mountain thrust fault, the trace of which bisects WAG 11 from northwest to southeast. The lowermost beds of the chickamauga are composed of thin bentonitic beds, gray clay shale, and maroon to gray calcareous siltstone. The majority of the chickamauga, approximately 1,500 feet thick, is a dominantly gray, dense, finely crystalline, thin bedded limestone with varying amounts of chert. The uppermost beds consist of yellow and maroon calcareous siltstone and blue-gray limestone. The Rome Formation is composed of interbedded sandstone, siltstone, shale and locally, dolomite.

\section{3 sample collection}

No samples were collected during drilling. 
ERC / EDGE

Environmental

and Energy

Services Co.

\subsection{Installation and Development}

\subsubsection{Installation}

This was a Type B well. A 22.0-inch diameter boring was augered from ground surface to 6.0 feet. A 15 3/4inch diverter casing was installed from surface to 6.0 feet below ground surface and grouted in place. The boring was drilled with a 14.0-inch air rotary tricone roller bit from 6.0 feet to 40.0 feet and tremie grouted in place. The surface casing minimizes potential cross contamination between the regolith and bedrock water bearing zones. After the surface casing was installed, the air rotary method was used to drill an 8-inch diameter boring to a total depth of 86.63 feet. A 2-inch diameter stainless steel silt trap was installed from 71.4 feet to 86.63 feet. A 2inch diameter stainless steel screen was installed from 56.4 feet to 71.4 feet. A 2-inch diameter stainless steel casing was installed from the top of the screen at 56.4 feet and extended 2.05 feet above ground surface. A sandpack ws then tremied into the annular space from 86.63 up to 53.0 feet, with a 2.6 foot bentonite pellet seal poured into the annular space above the sandpack from 50.4 to 53.0 feet. The annular space from the top of the bentonite seal to the surface was tremie grouted with a cement/bentonite slurry. A detailed schematic of the well is included on the well installatin/completion form.

\section{4 .2 Well Development}

Well number 1246 was developed to remove drill cuttings, silt, and other fines. The monitoring was 
developed using a Geoguard pump with an air rotary.

All pumps were cleaned prior to use according to

specified cleaning procedures (see Paragraph 2.1). The well was developed until a measured total of 552 gallons of water had been evacuated and the clarity of the discharge water was approved by the company representative. The final turbidity value measured at completions was $4.0 \mathrm{NTU}$ 's. A development form showing the exact method of development and other pertinent data is appended.

\subsubsection{Installation of Dedicated Konitoring Well Dump}

After the well was developed, a Geoguard Model No. 5614 dedicated monitoring well pump was installed on $10 / 10 / 90$ at a depth of 62.0 feet below ground surface. These pumps are decontaminated at American Sigma and are sent prepackaged. A copy of the pump certification is kept on file at ORNL.

\subsection{Hydraulic conductivity Testing}

Well number 1246 was tested for the determination of hydraulic conductivity of the aquifer in the vicinity of the well screen. This was accomplished by instantaneously adding a known quantity of water to the monitoring well and measuring the recovery of the water level over time. The changing water levels were measured using a Druck 15 psi pressure transducer and an Omnidata Datapod II data recorder. The hydraulic 


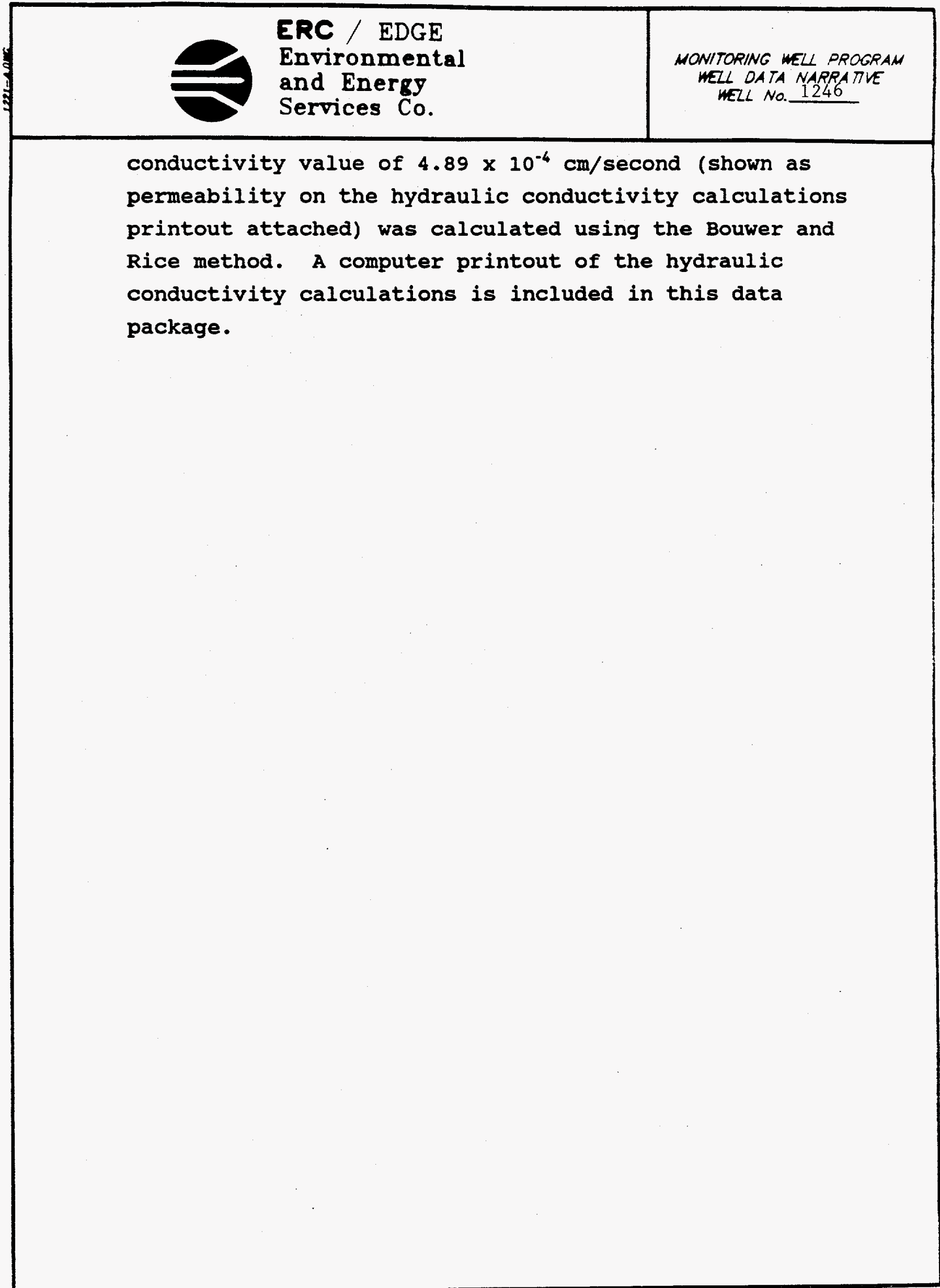




\section{PRE-DRILLING CHECKLIST FOR MONITORING WELLS}

\section{RRE-ORILUNG TASKS}

1. EXCAVTION PERMIT OBTAINED

2. ALL EQUIPMENT HAS BEEN CLEANED BEFORE DRILLING.

3a. SCREEN AND CASING HAVE BEEN WASHED, STEAMED, RINSED WIT DE-IONIZED OR DISTLLED WATER, RINSED WTH ISOPROPY ALCOHOL, WRAPPED WTH PROTECTVE COVERING AND STORED OFF THE GROUND.

36. PRE-PACKAGED SCREENS, CASING AND CENTRALIZERS WERE USED.

4. WORK AREA FOR SAMPLE EXAMINA TON COVERED WTH CLEAN POL YETHRENE.

5. CLEAN KNIVES, QLOVES, SAMPLE JARS AND LABELS ON HAND.

6. POLYETHRENE COVER IN PLACE OVER HOLE.

7. AIR ROTARY COMPRESSED AIR SAMPLED.
COMPLIANCE

$$
\frac{{ }_{1 / 23 / 90} \frac{\text { NIITLS }}{10 / 5}}{1 / 23 / 90}
$$$$
\mathrm{N} / \mathrm{A}
$$

$9 / 24 / 90$

$12 n$

$1 / 23 / 90$

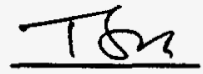

$1 / 23 / 90$

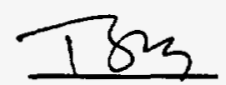

$1 / 23 / 90$

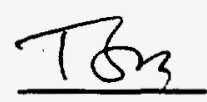

RESULTS:

ADOIMONAL NOTES/OBSERVATIONS:

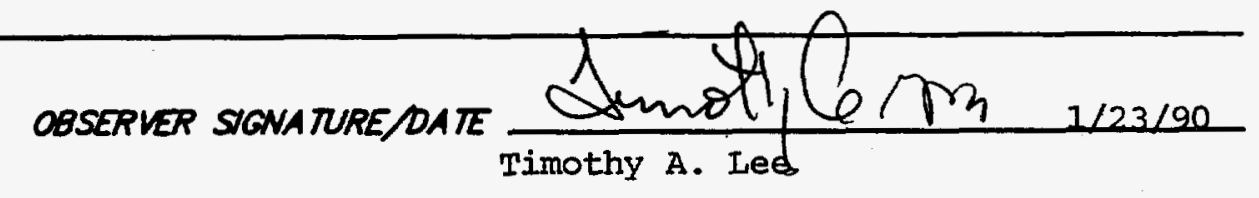

PAGE 8 of 21. 


\section{DECONTAMINATION CHECKLIST DRILLING EQUIPMENT}

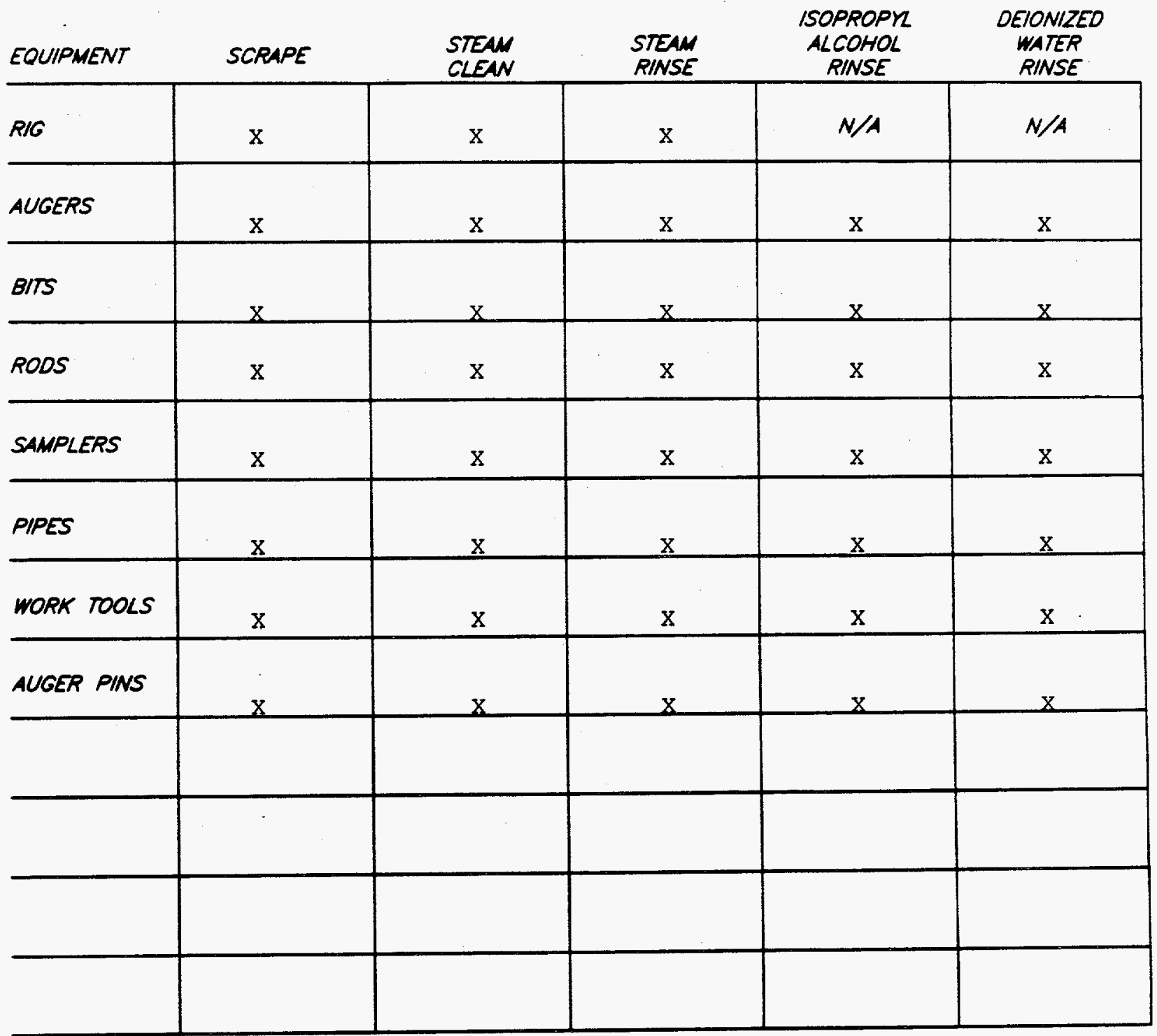

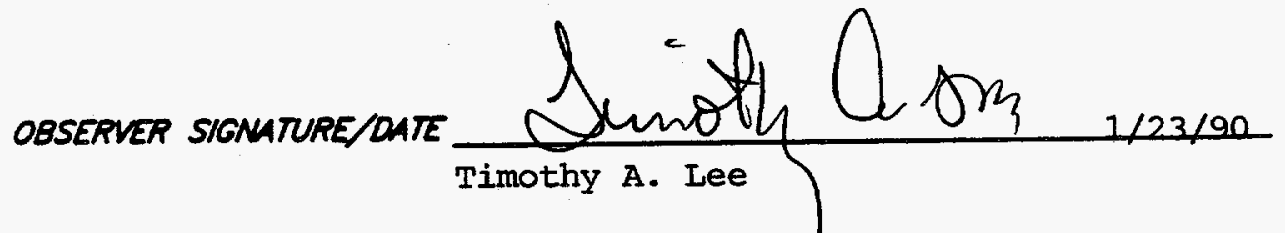




\begin{tabular}{|c|c|c|c|c|}
\hline \multicolumn{5}{|c|}{$\begin{array}{l}\text { ERe / EDGS } \\
\text { Environmental } \\
\text { and Energy } \\
\text { Services Co. }\end{array}$} \\
\hline \multicolumn{4}{|c|}{ ORNL MONITORING WELL LOG } & PACE $\perp$ or 3 \\
\hline \multirow{4}{*}{\multicolumn{2}{|c|}{$\begin{array}{l}\text { LOCA ION: } \\
\text { DRILLER: } \\
\text { HELPER: } \\
\text { ORKL: }\end{array}$}} & WAG 11 & & \multirow{4}{*}{$\begin{array}{l}\text { DATE: START: } \frac{1 / 23 / 90}{3 / 7 / 90} \\
\text { FINISH: } \frac{1}{\text { LOGGED BY: B_McMaster/Timathy A.IE }} \\
\text { HEALTH PHYSICIST: N/A }\end{array}$} \\
\hline & & Larry Led & etter & \\
\hline & & Fred Dixor & & \\
\hline & & IR-T-4 & & \\
\hline \multirow{2}{*}{\multicolumn{5}{|c|}{$\begin{array}{l}\text { THPE ORULUNG: Allger/Split Spon/Air } \\
\text { No. SAMPLES TAKEN: None } \\
\text { CONTANMENT MPE: Metal Pan/plastic }\end{array}$}} \\
\hline & & & & \\
\hline \multirow{2}{*}{\multicolumn{5}{|c|}{$\begin{array}{l}\text { THICKNESS OF SOH (REFUSAL DEPTH):- } \\
\text { OEPTH DRILED IN ROCK: } 62.5 \\
\text { TOTAL DEPTH OF WELL: } \frac{85.0}{1}\end{array}$}} \\
\hline & & & & \\
\hline \multicolumn{2}{|c|}{\begin{tabular}{|c|}
\multicolumn{2}{|c|}{ OEPTH } \\
(FEET) \\
FROW \\
FRO TO
\end{tabular}} & $\begin{array}{l}\text { SAMPLE } \\
\text { (NUMBER } \\
\text { INTERVAL) }\end{array}$ & $\begin{array}{c}\text { PERCEENT } \\
\text { RECOVERY } \\
\text { (SPLIT SPOONS) }\end{array}$ & SOL BEDROOK OESCRIPTION \\
\hline $\begin{array}{ll}0 \\
\end{array}$ & 30 & & & Grave ] pad \\
\hline \multirow[t]{2}{*}{3.0} & 5.0 & & $10 \%$ & Clay, moderate brown with minor light brown \\
\hline & & & & siltstone fragments. Sone dark organics \\
\hline 5.0 & 7.0 & & $0 \%$ & \\
\hline 7.0 & 8.0 & & $100 \%$ & Moderate yellowish-brown clay with light tan \\
\hline \multirow[t]{2}{*}{8.0} & 9.0 & & & Silty lenses-minor organics- minor maroon \\
\hline & & & & siltstone fragments \\
\hline 9.0 & 10.0 & & $100 \%$ & Dry grayish-red silty shale with minor tan \\
\hline \multirow[t]{2}{*}{10.0} & 10.5 & & & Silty lenses, pale brown silty clay with minor \\
\hline & & & & siltstone lenses-slightly damp \\
\hline \multirow[t]{2}{*}{10.5} & 11,0 & & & Moderate yellowish brown clay, slightly damp \\
\hline & & & & with minor light tan silty clay lenses \\
\hline 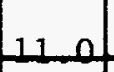 & 12 & & $100 \%$ & Dark yellowish oragne clay, wet \\
\hline \multirow[t]{2}{*}{120} & 13.0 & & & Pale brown silty shale with minor pale orange \\
\hline & & & & sandy lenses \\
\hline \multirow[t]{3}{*}{13.0} & 14.0 & & $100 \%$ & Wet, mottled clays with minor siltstone \\
\hline & & & & fragments ranging from dark yellowish orange \\
\hline & & & & to pale orange \\
\hline \multirow[t]{3}{*}{14.0} & 14.5 & & & Pale brown and light olive gray shales with \\
\hline & & & & minor orange yellow clays, bedding distinct1y \\
\hline & & & & dipped in spoon \\
\hline
\end{tabular}

PAGE 10 of 21. 


\section{ERC / EDGE \\ Environmental \\ and Energy \\ Services Co.}

\begin{tabular}{|c|c|c|c|c|}
\hline \multicolumn{4}{|c|}{ ORNL MONITORING WELL LOG } & PAGE 2 2- OF 3 \\
\hline \multicolumn{2}{|c|}{$\begin{array}{c}\text { DEPTH } \\
\text { (FEET) } \\
\text { FROM TO }\end{array}$} & $\begin{array}{l}\text { SAMPLE } \\
\text { (NUMBER \& }\end{array}$ & $\begin{array}{c}\text { PERCENT } \\
\text { RECOVERY } \\
\text { SPIT SPOONS }\end{array}$ & SOIL/BEDROCK DESCRIPTON \\
\hline \multirow[t]{2}{*}{14.5} & 15.0 & & $100 \%$ & Pale brown - maroon siltstone with minor clays. \\
\hline & & & & pale orange - light gray \\
\hline \multirow[t]{2}{*}{15.0} & 5.5 & & $100 \%$ & Moderate brown silty shale with fragments of \\
\hline & & & & blackish-red siltstone- damp \\
\hline \multirow[t]{3}{*}{15.5} & 17.0 & & $100 \%$ & Wet, moderate brown siltstones with pale \\
\hline & & & & greenish-yellow shaley clays. Minor pale \\
\hline & & & & yellow siltstone fragments to pale orange \\
\hline \multirow[t]{3}{*}{170} & 120 & & & Wet, pale brow silty shale, minor pale orange \\
\hline & & & & clays and greenish-yellow clays. Bulk density \\
\hline & & & & taken from $18.0^{\prime}$ to $18.4^{\prime}$ equals $2.00 \mathrm{~g} / \mathrm{cm}^{3}$ \\
\hline \multirow[t]{2}{*}{19.0} & 20. & & $100 \%$ & Wet, pale yellow brown-yellow orange silty shale \\
\hline & & & & with pale brown siltstone lenses \\
\hline \multirow[t]{2}{*}{20.0} & 21,0 & & $100 \%$ & Iight olive gray - yellowish gray silty shale; \\
\hline & & & & slightly calcareous at $20.7^{\prime}-\mathrm{dry}$ \\
\hline \multirow[t]{4}{*}{21.0} & 22.0 & & $50 \%$ & Dark yellowish orange silty clay with minor pale \\
\hline & & & & greenish yellow silty clay - wet \\
\hline & 220 & & & Split spoon refusal \\
\hline & 225 & & & Auger refusal \\
\hline \multirow[t]{3}{*}{22.5} & 25,0 & & Air Rotary & Siltstone, pale olive to grayish brown, black \\
\hline & & & & streaks, scattered fragments of sandstone, \\
\hline & & & & yellowish-gray medium grained \\
\hline \multirow[t]{2}{*}{25,0} & 30.0 & & Air Rotary & Siltstone, pale olive to grayish-brown. \\
\hline & & & & scattered, fragments of sandstone \\
\hline \multirow[t]{3}{*}{30.0} & 35.0 & & Air Rotary & Siltstone: pale olive to grayish brown, \\
\hline & & & & scattered fragments of yellowish gray, medium \\
\hline & & & & grained sandstones \\
\hline \multirow[t]{3}{*}{35.0} & 40.0 & & Air Rotary & Siltstone, pale olive to grayish brown, \\
\hline & & & & scattered fragments of yellowish gray. medium \\
\hline & & & & grained sandstomes \\
\hline \multirow[t]{2}{*}{45.0} & 50.0 & & Air Rotary & Tan - light gray calcareous siltstone - highly \\
\hline & & & & weathered, crumbly. Minor green siltstone \\
\hline 50.0 & 55.0 & & Air Rotary & Tan to light maroon siltstone, highly weathered, \\
\hline & & & & \\
\hline
\end{tabular}




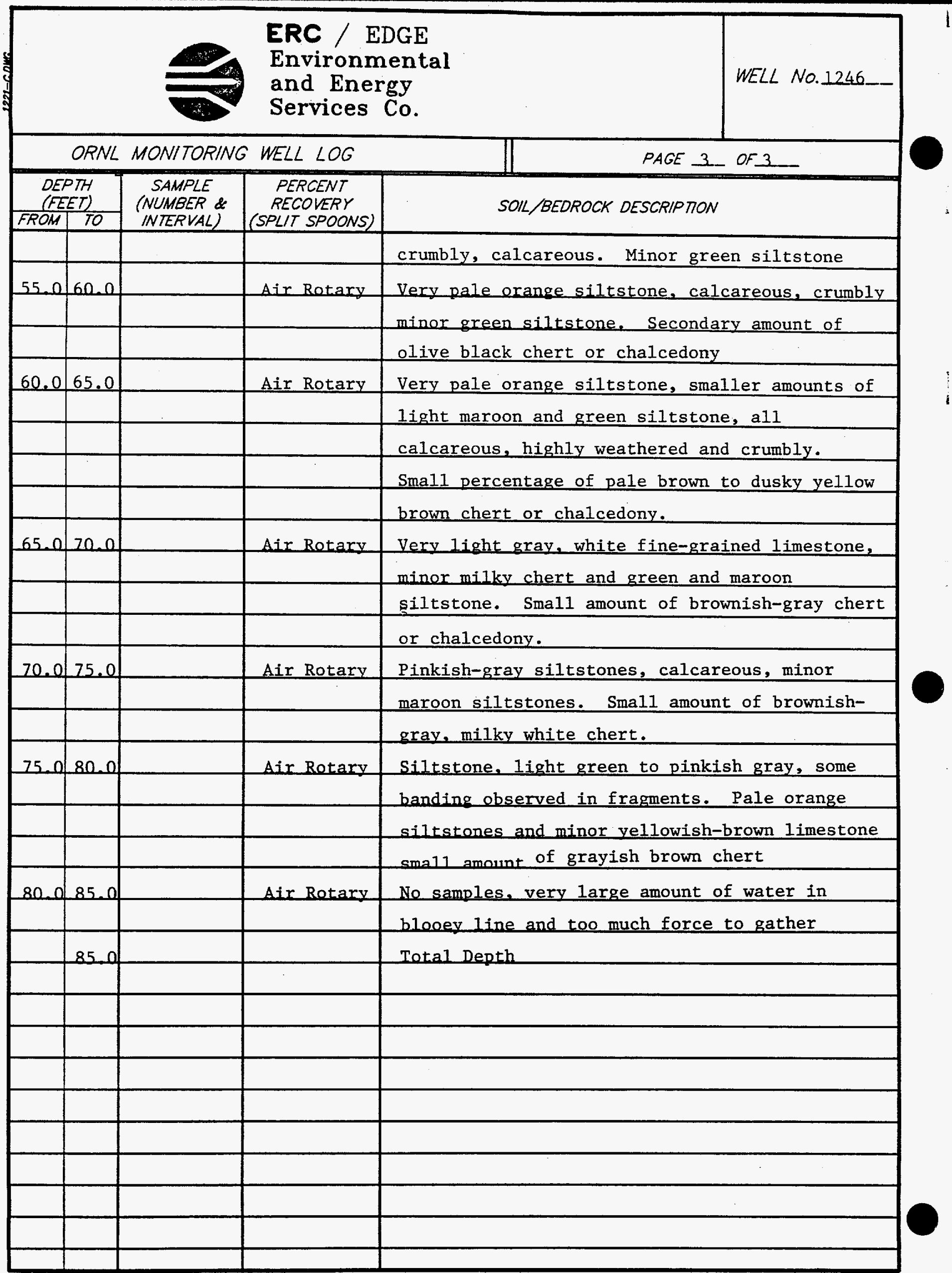


WELL INSTALLATION/COMPLETION FORM

\section{LOGGED}

BY: Michael I. Ebers

O.R.N.L. MONITORING WELL PROGRAM PROOFED

$B Y$ : James Caruthers
DRILING COMPANY: Geotek

DRILLER: Larry Ledbetter HELPER: Fred Dixon
LOCA ION WAGII ORNL GRID COORDINATES $N 35,090.0576$ E 27,507.5298 ELEV. GROUND 825.90 ELEV. TOP STAINLESS STEEL CASING 827.95 DRILLING DATES: STARTED: $1 / 23 / 90$ FINISHED: $9 / 26 / 90$

DRILLING METHOD:

$\square-22$
$\square \frac{14.5}{8.0}$
INCH AUGER 10.5 INCH AUGER INCH ROTARY 29.5 L.F. L.F. INCH ROTARY 46.63

MATERIALS USED

EST. USED

va vo

VIA POUNOS OF BENTONTE PEIETS (SURFACE CASNG SEN) 10.5 F. of 16 N. SURACE CASNG - Diverter

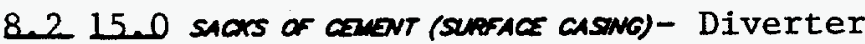
25.0 pounos of powered eovrowite (suesace caswg) 90.0 ancons of WATER (SUNACE CASNG) - Diverter 40.0 FT. of 10 _N. SURFACE CASNG

12.824 .0 sicts of congut (suprace casang) 120 pounos of POWERED BENTOWIE (SURFACE CASWG)

144 GNLOWS of WATER (SCRFACE CASING)

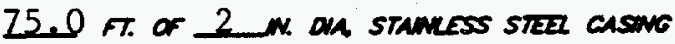

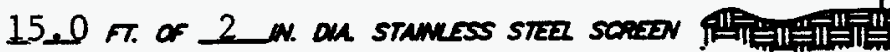
8.213 .0 sucrs of suno 50 50.0 pands of EOVTONTE PQUETS

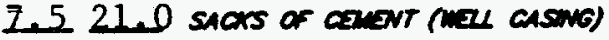
25.0 panos of powgres eovrowite (WZL CASNG)

126.0 ancons of watre (MEL caswa) 43.12 r. of $394 \mathrm{~N}$ stzel motecme caswo

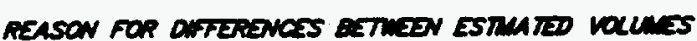
no used valuess

Large void at $60^{\prime}$ to $85^{\prime}$

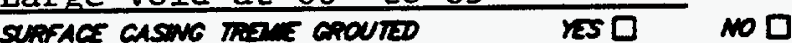
STANLESS ster caswo REUE GROUTLO wal cover used res $\quad$ No

L LOANus STIS COVER

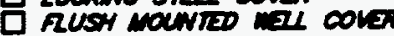
ORive

SRT The cose ves D NOC MONITORING WELL PUMP BASE SET AT 62.0 FEET. CENTRALIZERS AT N/A FEET.
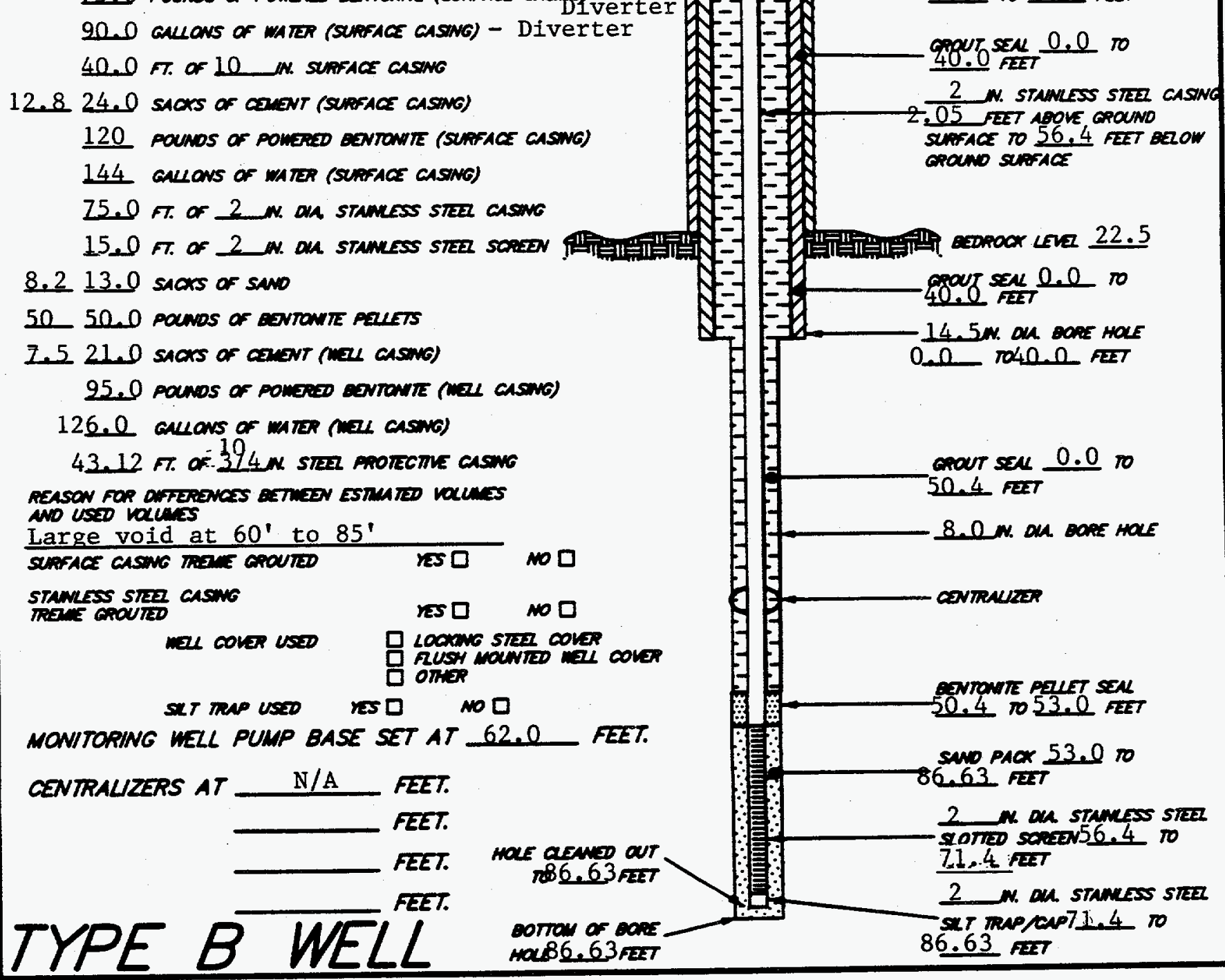

$16 "$ diverter casing 22.0N. OM Dore hoL 0.0 rollo. 5 FET Q70. 2 N. STAMEES STEZ GASNC 2.05 REET AOOVE GROUNO seriface to 56.4 FET BZOW crano surface

PROTECTIE GASARG 3 . 12 FEET APOKE GROUNO SURFACE TO 40.0 RET BezOW GRONO surface

CONDEETE PAO
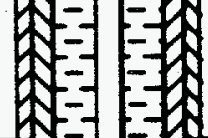

NOTE: 


\section{ERC / EDGE}

Environmental

WELL NO. 1246

and Energy

Services Co.

\section{MONITORING WELL MATERIALS CERTIFICATION}

ITEM/MA TERIAL

DAIE USED BATCH NUMBER

SAND

BENTONITE

Powder

Pellets

STAINLESS STEEL SCREEN

STAINLESS STEEL CASING

STAINLESS STEER CENTRALIZERS

STAINLESS STEEL CAPS

MONITORING WELL PUMP

GROUT

surface casing

well casing

\begin{tabular}{|c|c|c|}
\hline $\begin{array}{c}\text { reS } \\
\text { NO }\end{array}$ & $9 / 24 / 90$ & 4 \\
\hline$\left(\begin{array}{c}\text { res } \\
\text { NO }\end{array}\right.$ & $9 / 24 / 90$ & 4 \\
\hline $\begin{array}{c}\text { rES } \\
\text { NO }\end{array}$ & $9 / 24 / 90$ & 4 \\
\hline $\begin{array}{l}\text { rES } \\
\text { NO }\end{array}$ & $9 / 24 / 90$ & 4 \\
\hline $\begin{array}{cc}r E S \\
\text { NO }\end{array}$ & $10 / 10 / 90$ & 8 \\
\hline sing & $2 / 21 / 90$ & 7 \\
\hline 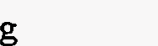 & $9 / 26 / 90$ & 7 \\
\hline
\end{tabular}

WELL COVERS

SURFACE CASING

$2 / 20 / 90$

4

COMMENTS:

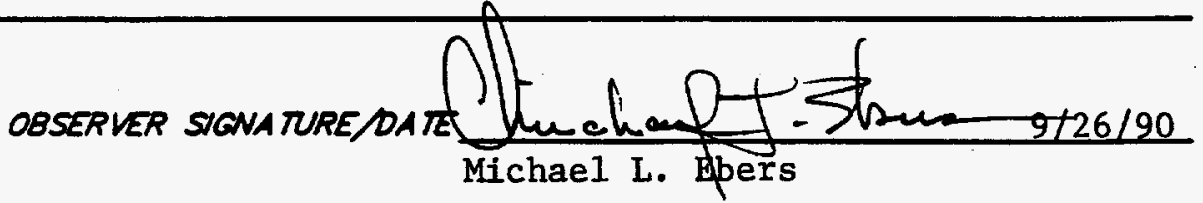

PAGE 14 of 21 . 


\section{POST-MELL COMPLETION CHECKLIST}

\section{POST-MELL COMPLETION TASKS}

\section{COMPLIANCE DA.E $\quad$ INITIALS}

1. WU SCRAPEO FROW AUCERS SAMPLERS ANO ALL $9 / 25 / 90 \quad$ ALE OTHER EQUPMENT.

2. ALL WUD FRON RIG ANO EOUPMENT SCRAPNGS ANO 9/25/90 MUE CUTTINOS DISPOSED OF IN ACCORDANCE WIH THE segarica now phonozo.

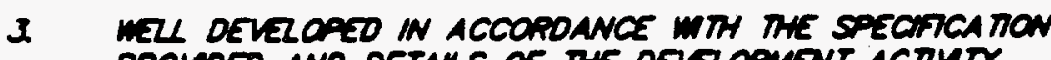

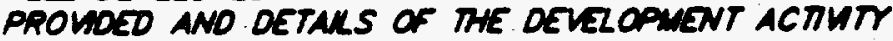
RECOROED.

4. DAKUNG SIE PROPERY CLANZD UP AFTER cOMPLETION of nZL WSTALLITON.

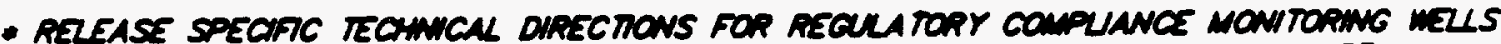

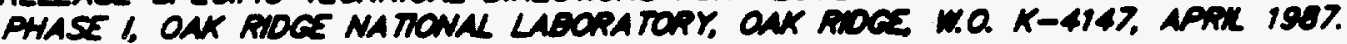

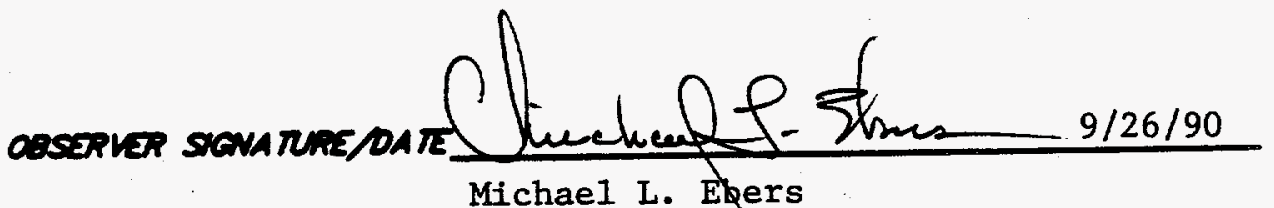

Michael L. Ekers

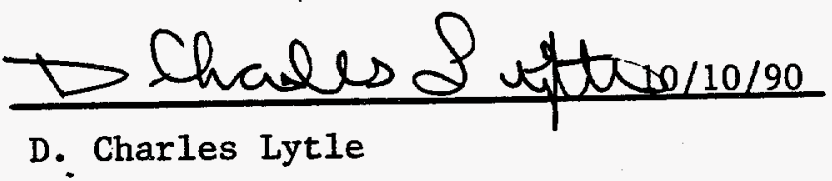




\section{ERCE}

Environmental

and Energy

WELL NO. 1246

Services Co.

\section{MONITORING WELL \\ DEVELOPMENT FORM}

DEVELOPMENT DETAILS

METHOD OF

DEVELOPMENT: Surging and pumping

DEVELOPMENT

BEGAN DATE: $\quad 10-04-90$

TME:

OEVELOPMENT

ENDING DATE: $\quad 10-10-90$

OEVELOPMENT

OBSERVED BY: D. Charles Lytle

ONE WELL VOLUME: 22.1 GALLONS

TOTAL GALLONS PUMPED: 552 TOTAL WELL VOLUMES PUMPED: 25.0

INITAL PH: 9.0 FNAL PH: 8.6

INITAL CONDUCTUTY (KS/Cm): 347 FNAL CONDUCHUTY ( $\mathrm{HS} / \mathrm{cm}): 373$

OESCRIPTION OF INIMAL TUREIDITY: MUddY

DESCRIPTION OF FNAL TURBIOITY: Clear

FINAL MEASURED TURBIOITY: 4.0 NTU'S

WEL APPROVED BY: R.C. Williams MMES

ODOR

QF WATRR. None

WATER GROUND SURFACE

DISCHARGED D STORW SEWERS

TO: $\quad$ DRUNS

TANK TRUCK

STORACE TANKS

口 OTHER

INITAL PRE-DEVELOPNENT

WATER DEPTH: $\quad 31.5$ feet from ground surface

DEVELOPMENT OBSERVATIONS

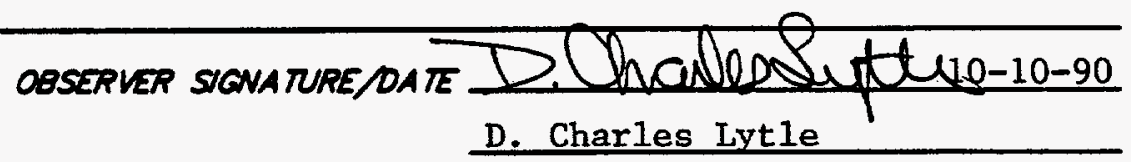




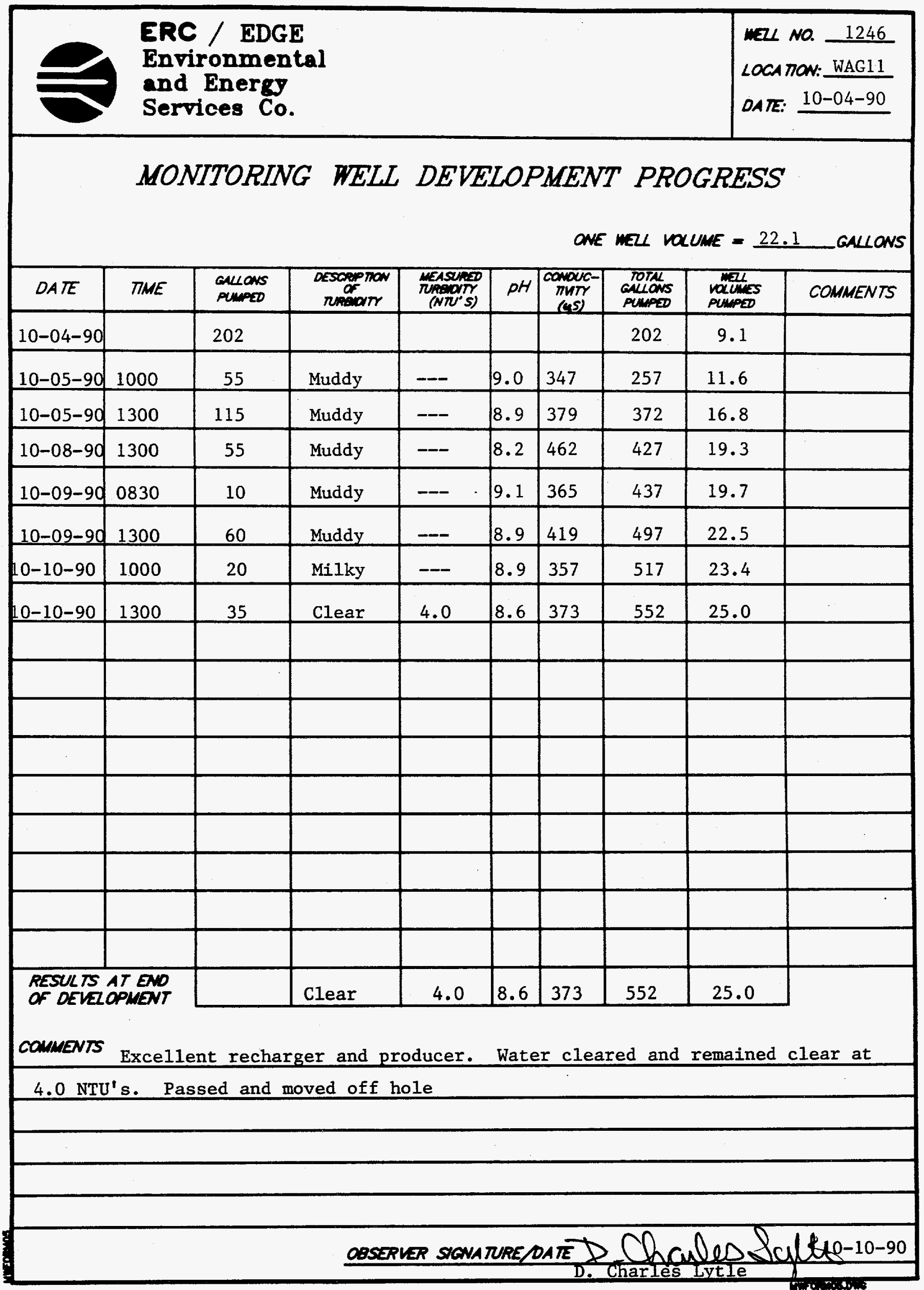

PACE 17 or 21 
ERC / EDGE

Environmental

and Energy

WELL NO. 1246

Services Co.

HYDRAULIC CONDUCTIVTY CALCULATIONS

PROGRAM SLUGT, VERSION 4.1, NOV. 1986

THIS PROGRAM CALCULATES MEAN TRANSMISSIVITIES FROM

SLUG-TEST DATA BASED ON TWO ANALYTICAL APPROACHES:

(1) METHOD OF COOPER, BREDEHOEFT AND PAPADOPULOS, 1967

(ARTICLE IN VOL.3, NO. 1 OF WRR ENTITLED

"RESPONSE OF A FINITE DIAMETER WELL TO AN INSTANTANEOUS

CHARGE OF WATER")

(2) METHOD OF BOUWER AND RICE, 1976 (ARTICLE IN

VOL. 12, NO.3 OF WRR ENTITLED

"A SLUG TEST FOR DETERMINING HYDRAULIC CONDUCTIVITY

OF UNCONFINED AQUIFERS WITH COMPLETELY OR PARTIALIY PENETRATING WELLS")

WELL NO.: 1246

DATE OF TEST: $10-12-90$

PROJECT NO.: E221-002

CLIENT: MMES

SITE LOCATION: WAG-11

EDGE, INC. FIELD INVESTIGATOR: JAMES W. CARUTHERS

INPUT DATA ARE:

INNER CASING DIAMETER $=2.00$ INCHES

INNER SCREEN OR OPEN-HOLE DIAMETER $=2.00$ INCHES

DIAMETER OF DRILLED HOLE $=8.00$ INCHES

LENGTH OF SCREEN OR INTAKE PORTION $=15.00$ FEET

DEPTH FROM STATIC IEVEL TO BOTTOM OF SCREEN $=55.40$ FEET

THICKNESS OF SATURATED AQUIFER ZONE $=15.00$ FEET

DEPTH TO STATIC WATER LEVEL BELOW REF. POINT $=1.00$ FEET

ESTIMATED POROSITY OF GRAVEL PACK $=.20$

FALLING-HEAD INDEX = 1 ("I" IF FALLING,"O" IF RISING)

NUMBER OF DEPTH-TIME DATA POINTS = 32

HO WAS COMPUTED FROM INTERCEPT OF PLOT OF LOG(H) VS. TIME

SUCCESSIVE COMPUTED

VALUES FOR HO

(FEET)

1.7625

1.7666 


\section{HYDRAULIC CONDUCTIVTY CALCULATIONS}

\begin{tabular}{|c|c|c|}
\hline$\left(\operatorname{SEC}^{\text {TIME }}\right)$ & $\begin{array}{l}\text { DEPTH TO WATER } \\
\text { (FEET) }\end{array}$ & $\begin{array}{l}\text { HEAD } \\
\text { (FEET) }\end{array}$ \\
\hline $\begin{array}{l}5.00 \\
10.00 \\
15.00 \\
20.00 \\
25.00 \\
30.00 \\
35.00 \\
40.00 \\
45.00 \\
50.00 \\
55.00 \\
60.00 \\
65.00 \\
70.00 \\
75.00 \\
80.00 \\
85.00\end{array}$ & $\begin{array}{r}3.560 \\
3.130 \\
2.730 \\
2.470 \\
2.270 \\
2.100 \\
1.940 \\
1.820 \\
1.690 \\
1.600 \\
1.520 \\
1.440 \\
1.410 \\
1.350 \\
1.300 \\
1.300 \\
1.280\end{array}$ & $\begin{array}{r}2.560 \\
2.130 \\
1.730 \\
1.470 \\
1.270 \\
1.100 \\
.940 \\
.820 \\
.690 \\
.600 \\
.520 \\
.440 \\
.410 \\
.350 \\
.300 \\
.300 \\
.280\end{array}$ \\
\hline $\begin{array}{r}90.00 \\
95.00 \\
100.00 \\
105.00 \\
110.00 \\
115.00 \\
120.00 \\
125.00 \\
130.00 \\
135.00 \\
140.00 \\
145.00 \\
150.00 \\
155.00 \\
160.00\end{array}$ & $\begin{array}{l}1.240 \\
1.230 \\
1.220 \\
1.210 \\
1.210 \\
1.200 \\
1.190 \\
1.190 \\
1.170 \\
1.160 \\
1.160 \\
1.150 \\
1.140 \\
1.130 \\
1.090\end{array}$ & $\begin{array}{l}.240 \\
.230 \\
.220 \\
.210 \\
.210 \\
.200 \\
.190 \\
.190 \\
.170 \\
.160 \\
.160 \\
.150 \\
.140 \\
.130 \\
.090\end{array}$ \\
\hline
\end{tabular}




\section{HYDRAULIC CONDUCTIVTY CALCULATIONS}

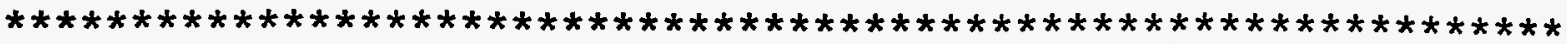

METHOD OF BOUWER AND RICE
}

COMPUTED RESULTS USING DIAMETER OF DRILLED HOLE:

$$
\begin{aligned}
& \text { PERMEABILITY }=1.61 \mathrm{E}-05 \mathrm{FT} / \mathrm{SEC}=4.89 \mathrm{E}-04 \mathrm{CM} / \mathrm{SEC} \\
& \text { TRANSMISSIVITY }=2.41 \mathrm{E}-04 \mathrm{FT} * 2 / \mathrm{SEC}
\end{aligned}
$$

COMPUTED RESULTS USING DIAMETER OF CASING AND SCREEN:

$$
\begin{aligned}
& \text { PERMEABILITY }=2.13 \mathrm{E}-05 \mathrm{FT} / \mathrm{SEC}=6.50 \mathrm{E}-04 \mathrm{CM} / \mathrm{SEC} \\
& \text { TRANSMISSIVITY }=3.20 \mathrm{E}-04 \mathrm{FT} * * 2 / \mathrm{SEC}
\end{aligned}
$$




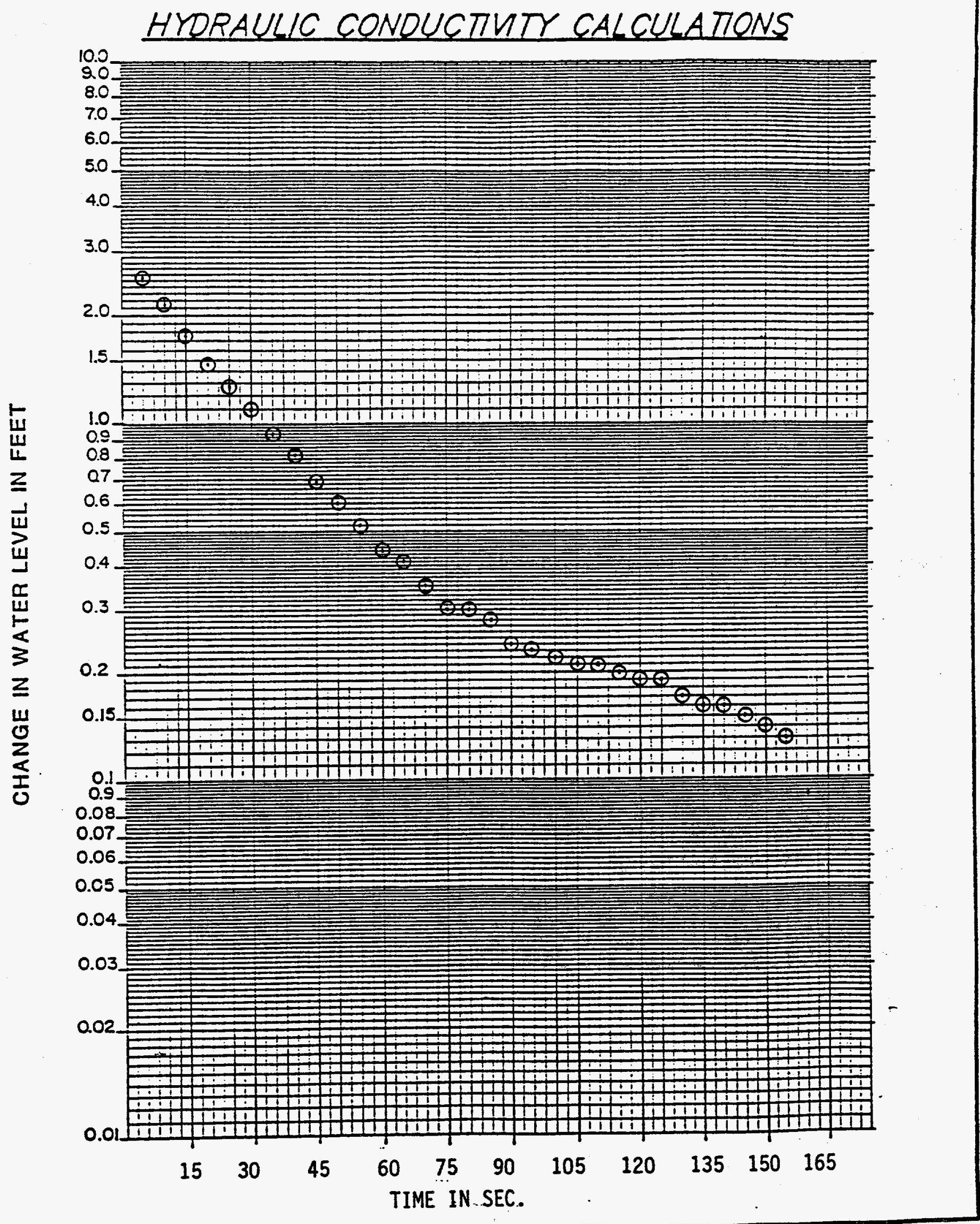


ERC / EDGE

Environmental

and Energy

Services Co.

\subsection{Well Location}

Monitoring well number 1149 is located in WAG 11. It is located in the southwestern portion of White Wing scrap Yard. The location is shown on ORNL drawing number C3E20004A075. Survey coordinates for this well are $N$ $34,973.5615$, E 29,702.2786 (X-10 grid) or latitude $35^{\circ}-57^{\prime}-14.83^{\prime \prime}$ and longitude $84^{\circ}-20^{\prime}-41.96^{\prime \prime}$. Coordinate data were provided by Martin Marietta Energy systems. The method used for conversion from $x-10$ grid to Tennessee-Lambert state Plane coordinates came from the publication "Tennessee Valley Authority Data Services Branch and Mapping Services Branch, Oak Ridge, Tennessee, DOE Plant Control, November 6, 1985, Field Book: ESS-3115, pp. 1-20." The latitude and longitude were calculated by Adams Craft Herz Walker Engineering, Inc., using methods from the U.S. Coast and Geodetic Survey Publication 62-4, "State Plane Coordinates by Automatic Data Processing."

\subsection{Drilling Information}

Well number 1149 was drilled by Geotek Engineering Company. An Ingersoll Rand T-4 rig was used to drill this boring for monitor well installation under operation of Larry Ledbetter with the assistance of Fred Dixon. Drilling commenced on 1-16-90 and was finished on 3-1-90. Paragraph 2.4.1 includes a detailed discussion of the well installation and a well schematic is included on the well installation/completion form. A synopsis of the 
drilling activity follows. This information was typed directly from field notes and was edited only when necessary for clarification.

01-16-90 The rig was mobilized to the staked location and set up on plastic sheeting. Split spoon samples were taken from surface to refusal at 12.5 feet. The boring was reamed using a 22inch auger to 7.2 feet. Set 7.2 feet of 15 3/4-inch decontaminated steel diverter casing and grouted it to surface. Move rig from location.

01-18-90 Move rig back to location. Drill from 7.2 feet to 18.5 feet using a 14 -inch air rotary tricone bit. Set 13.9 feet of $103 / 4$-inch decontaminated steel surface casing. Move rig from location.

01-19-90 Grouted surface casing annulus to surface iwth 8.0 sacks cement.

02-13-90 Move rig to location. Drill to 35.0 feet using an 8.0-inch air rotary.

03-01-90 Set 2-inch stainless steel well casing and screen with sand pack and bentonite seal.

03-02-90 Tremie grouted annulus with 4.0 sacks of cement.

This well was logged by ERC Environmental and Energy Services Co., Inc., hydrogeologists Timothy A. Lee and C. Allison Bailey. All well construction materials and supplies were from Martin Marietta Energy Systems approved batches. The batch origin of individual items is shown on the included Monitoring Well Materials Certification form. 


\subsection{Technical Information}

\subsection{Decontamination Procedures}

The drilling rig, down hole tools, surface casing, stainless steel screen, stainless steel casing, centralizers, and stainless steel silt trap underwent the cleaning decontamination procedures outlined in the drilling specifications (Release specific Tecinical Directions for Regulatory Compliance Monitoring Wells Phase 1, Oak Ridge National Laboratory, Oak Ridge, w.o., K-4147, April 1987, pgs, 2-4). A checklist of the cleaned materials is included with this data package.

\subsection{Geology}

The northeastern half of WAG 11 is underlain by Chickamauga Limestone. The Rome Formation underlies the southwestern half of WAG 11 . The Chickamauga Limestone is brought into contact with the Rome Formation by the White Oak Mountain thrust fault, the trace of which bisects WAG 11 from northwest to southeast. The lowermost beds of the Chickamauga are composed of thin bentonitic beds, gray clay shale, and maroon to gray calcareous siltstone. The majority of the Chickamauga, approximately 1,500' thick, is a dominantly gray, dense, finely crystalline, thin bedded limestone with varying amounts of chert. The uppermost beds consist of yellow and maroon calcareous siltstone and blue-gray limestone. The Rome Formation is composed of interbedded sandstone, siltstone, shale and locally, dolomite. 


\subsection{Sample collection}

One soil sample was collected during drilling, placed in an I-CHEM specialty cleaned glass container, sealed and submitted to Sample Receiving, Analytical Chemistry Division, Bldg. 4500S, ORNL. A chain of custody form for this sample is included with this data package. Soil sample 1149501 was collected in the split spoon interval from 10.3 feet to 10.7 feet on 1-16-90.

A bulk density soil sample was collected from the split spoon sample interval from 10.3 to 10.7 feet. The sample was measured, weighed and a bulk density of 1.78 grams $/ \mathrm{cm}^{3}$ was calculated.

The Ingersoll Rand T-4 compressed air was sampled with a cloth filter inserted between drill rods on 2-13-90. The sample was examined with an ultraviolet light for the presence of hydrocarbons. The filter showed no detectable signs of hydrocarbons.

\subsection{Installation and Development}

\subsubsection{Installation}

This was a Type B well. A 22.0-inch diameter boring was augered from ground surface to 7.2 feet. A 15 3/4-inch diverter casing was installed from surface to 7.2 feet below ground surface and grouted in place. The boring was then extended past the diverter casing depth with a 14.0-inch air rotary tricone. roller bit from 7.2 feet to 18.5 feet. A $103 / 4-$ inch diameter string of decontaminated steel surface casing was installed from 0.0 feet to 13.9 feet, sealed with a 2.0 -foot bentonite 
pellet layer from 11.9 feet to 13.9 feet, and tremie grouted in place. The surface casing minimizes potential cross contamination between the regolith and bedrock water bearing zones. After the surface casing was installed, the air rotary method was used to drill an eight-inch diameter boring to a total depth of 35.0 feet. A two-inch diameter stainless steel screen with threaded bottom cap was installed from 17.5 feet to 32.8 feet. A two-inch diameter stainless steel casing was installed from the top of the screen at 17.5 feet and extended 2.4 feet above ground surface. A sandpack was then tremied into the annular space from 16.0 to 32.8 feet, with a 1.9-foot bentonite pellet seal poured into the annular space above the sandpack from 14.1 to 16.0 feet. The annular space from the top of the bentonite seal to the surface was tremie grouted with a cement/bentonite slurry. A detailed schematic of the well is included on the well installation/completion form.

\subsubsection{Well Development}

Well number 1149 was developed to remove drill cuttings, silt, and other fines. The monitoring was developed using a Geoguard pump with an air compressor. All pumps were cleaned prior to use according to specified cleaning procedures (see Paragraph 2.1). The well was developed until a measured total of 221 gallons of water had been evacuated and the clarity of the discharge water was approved by the company representative. The final turbidity value measured at completion was 5.0 NTU's. A development form showing the exact method of development and other pertinent data is appended. 
ERC / EDGE

Environmental

and Energy

Services Co.
MONITORING WELL PROGRAM

WEZL DATA NARRATVE

WELL NO. 1149

\subsubsection{Installation of Dedicated Monitoring Well Pump}

After the well was developed, a Geoguard Model No. 5614 dedicated monitoring well pump was installed on $7 / 30 / 90$ at a depth of 31.3 feet below ground surface. These pumps are decontaminated at American Sigma and are sent prepackaged. A copy of the pump certification is kept on file at ORNL.

\subsection{Hydraulic conductivity Testing}

Well number 1149 was tested for the determination of hydraulic conductivity of the aquifer in the vicinity of the well screen. This was accomplished by instantaneously adding a known quantity of water to the monitoring well and measuring the recovery of the water level over time. The changing water levels were measured using a Druck $15 \mathrm{psi}$ pressure transducer and an Omnidata Datapod II data recorder. The hydraulic conductivity value of $4.62 \times 10^{-5} \mathrm{~cm} /$ second (shown as permeability on the hydraulic conductivity calculations printout attached) was calculated using the Bouwer and Rice method. A computer printout of the hydraulic conductivity calculations is included in this data package. 


\section{PRE-DRILLING CHECKLIST FOR MONITORING WELLS}

PRE-DRILUING TASKS

1. EXCAVTION PERMIT OBTAINED

2. ALL EOUIPNENT HAS BEEN CLEANED BEFORE DRILING.

30. SCREEN AND CASING HAVE BEEN WASHED, STEAMED, RINSED WTH DE-IONIZED OR DISTLLED WATER, RINSED WTH ISOPROPN ALCOHOL, WRAPPED WTH PROTECTVE COVERING AND STORED OFF THE GROUND.

36. PRE-PACKAGED SCREENS, CASING AND CENTRALIZERS WERE USED.

4. WORK AREA FOR SAMPLE EXAMINATION COVERED WTH CLEAN POLYETHRENE.

5. CLEAN KNIVES, GLOVES, SAMPLE JARS AND LABELS ON HAND.

6. POL YETHRENE COVER IN PLACE OVER HOLE.

7. AIR ROTARY COMPRESSED AIR SAMPLED.

GOMPLIANCE

\section{DAIE}

01-16-90

01-15-90

$N / A$

03-01-90

01-16-90

01-16-90

$01-16-90$

02-13-90
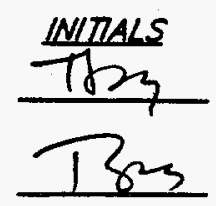

$N / A$
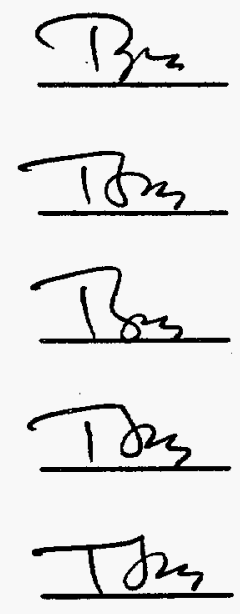

RESUL TS: No hydrocarbons detected under ultraviolet light.

ADDITONAL NOTES/OBSERVATIONS:

OBSERVER SIGNATURE DATE

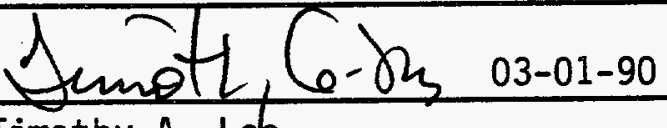

Timothy A. Lee 


\section{DECONTAMINATION CHECKLIST DRILLING EQUIPMENT}

\begin{tabular}{|c|c|c|c|c|c|}
\hline EQUIPMENT & SCRAPE & $\begin{array}{l}\text { STEAN } \\
\text { CLEAN }\end{array}$ & $\begin{array}{l}\text { STEAM } \\
\text { RINSE }\end{array}$ & $\begin{array}{c}\text { ISOPROPYL } \\
\text { ALCOHOL } \\
\text { RINSE }\end{array}$ & $\begin{array}{c}\text { OEIONIZED } \\
\text { WATER } \\
\text { RINSE }\end{array}$ \\
\hline$R / G$ & $x$ & $x$ & $x$ & $N / A$ & $N / A$ \\
\hline AUGERS & $x$ & $x$ & $x$ & $x$ & $x$ \\
\hline BITS & $x$ & $x$ & $x$ & $x$ & $x$ \\
\hline ROOS & $x$ & $x$ & $x$ & $x$ & $x$ \\
\hline SAMPLERS & $x$ & $x$ & $x$ & $x$ & $x$ \\
\hline PIPES & $x$ & $x$ & $x$ & $x$ & $x$ \\
\hline WORK TOOLS & $x$ & $x$ & $x$ & $x$ & $x$ \\
\hline AUGER PINS & $x$ & $x$ & $x$ & $x$ & $x$ \\
\hline & & & & & \\
\hline & & & & & \\
\hline & & & & & \\
\hline & & & & & \\
\hline
\end{tabular}

OBSERVER SIGMATURE/OATE Sumotle-Ce.Dhy 03-01-90 
ORNL MONITORING WELL LOG

LOCA MON: WAG-11

ORILER: Larry Ledbetter

HELPER: Fred Dixon

DRUL: Ingersol Rand T-4

TPE ORILLNG: Split Spoon, Auger

No. SAMPLES TAKEN: One

CONTANMENT TrPE: Plastic, Pan

THOKNESS OF SOL (RETUSN DEPTH): 12.5

OEPTH DRIULO IN ROOX: 22.5

TOTAL OEPTH OF MEL. 35.0

\section{PACE 1 of 2}

DATE: START: 01-16-90

FNISH: 03-01-90

LOOCEO Br. Timothy A. Lee

HEAL TH PHYSICIST: N/A

LUBRICANT MPE: Green Stuff TPE: Soil

\begin{tabular}{|c|c|c|c|c|}
\hline \multicolumn{2}{|c|}{$\begin{array}{l}\text { DEPNH } \\
\text { (FEEN) }\end{array}$} & $\begin{array}{l}\text { SAMFEE } \\
\text { (NUMESR } \\
\text { INTERVA) }\end{array}$ & $\begin{array}{c}\text { PERCENT } \\
\text { RECOVERY } \\
\text { (SPUT SPOONS) }\end{array}$ & sau beproak arscintion \\
\hline 0.0 & 4.0 & & & Gravel pad. \\
\hline \multirow[t]{4}{*}{4.0} & 4.9 & & $100 \%$ & Clay, mottled, dark yellowish orange, light \\
\hline & & & & brown and grayish; slightly sandy, silty, \\
\hline & & & & some organic material, dry to moist, clay \\
\hline & & & & matrix. \\
\hline \multirow[t]{2}{*}{4.9} & 6.0 & & & Light gray-moist, with grayish red siltstone \\
\hline & & & & with organics. \\
\hline \multirow[t]{2}{*}{6.0} & 8.0 & & $100 \%$ & Clay, mottled, dark yellowish to moderate \\
\hline & & & & brown streaks. Light gray-red siltstone. \\
\hline \multirow[t]{2}{*}{8.0} & 10.0 & & $100 \%$ & Sandy--sand lenses and organics--very hard \\
\hline & & & & and dense clay. Water out of spoon. \\
\hline \multirow[t]{4}{*}{10.0} & 12.0 & $1149 S 01$ & & Wet clay, light gray-dark yellowish orange; \\
\hline & & $10.3-10.7$ & & organics present with pale yellowish orange \\
\hline & & Bulk dens ity & & silty lenses of clay. Minor siltstone \\
\hline & & $10.3-10.7$ & & fragments. Bulk density $=1.78 \mathrm{grams} / \mathrm{cm}^{3}$. \\
\hline \multirow[t]{3}{*}{12.0} & 12.2 & & $100 \%$ & Wet clay--dark yellowish brown to brown with \\
\hline & & & & dark organics. \\
\hline & 12.2 & & & Spoon refusal. \\
\hline \multirow[t]{2}{*}{12.2} & 12.5 & & Augered & \\
\hline & 12.5 & & & Auger refusal. \\
\hline & & & & \\
\hline
\end{tabular}




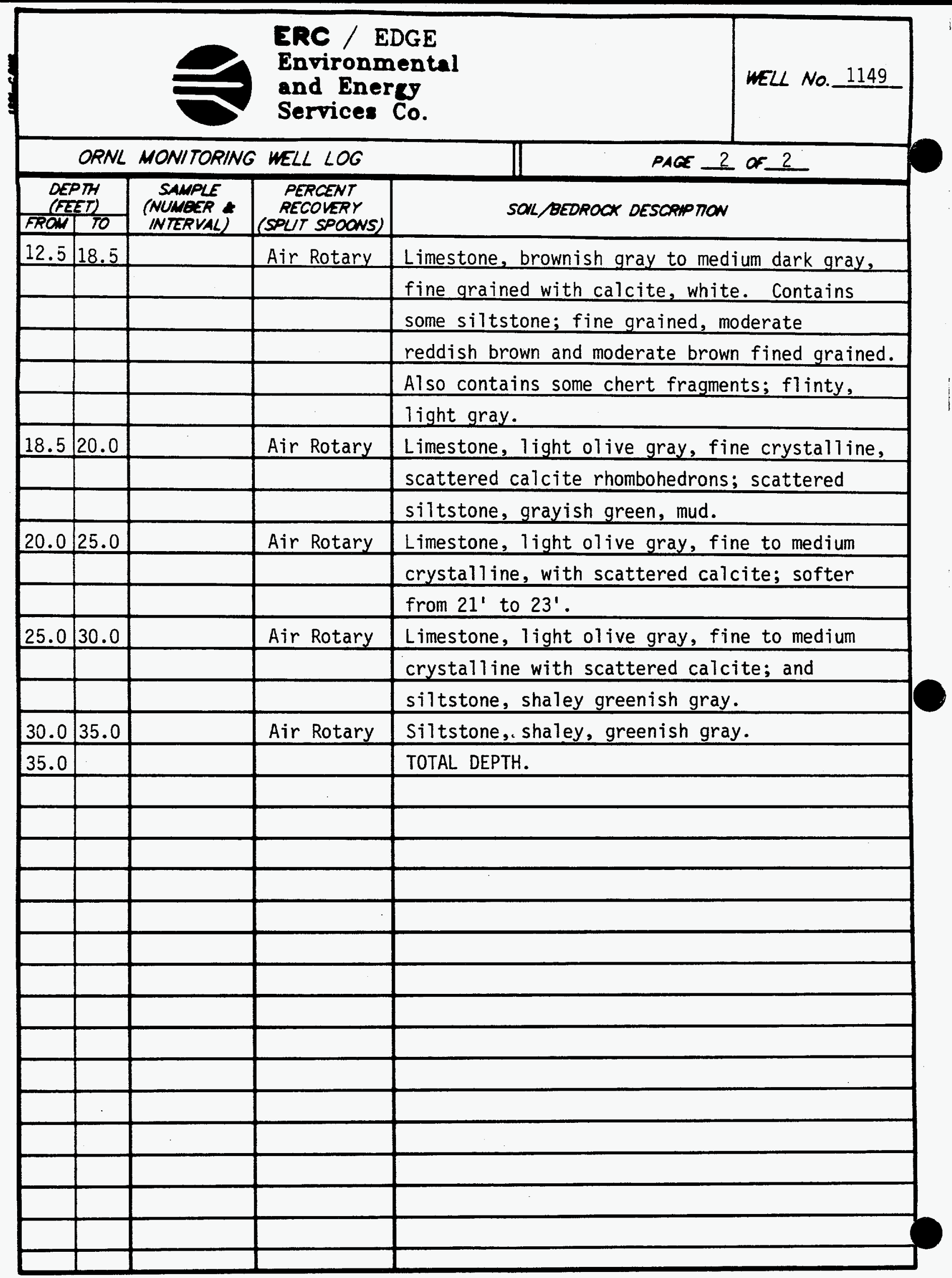




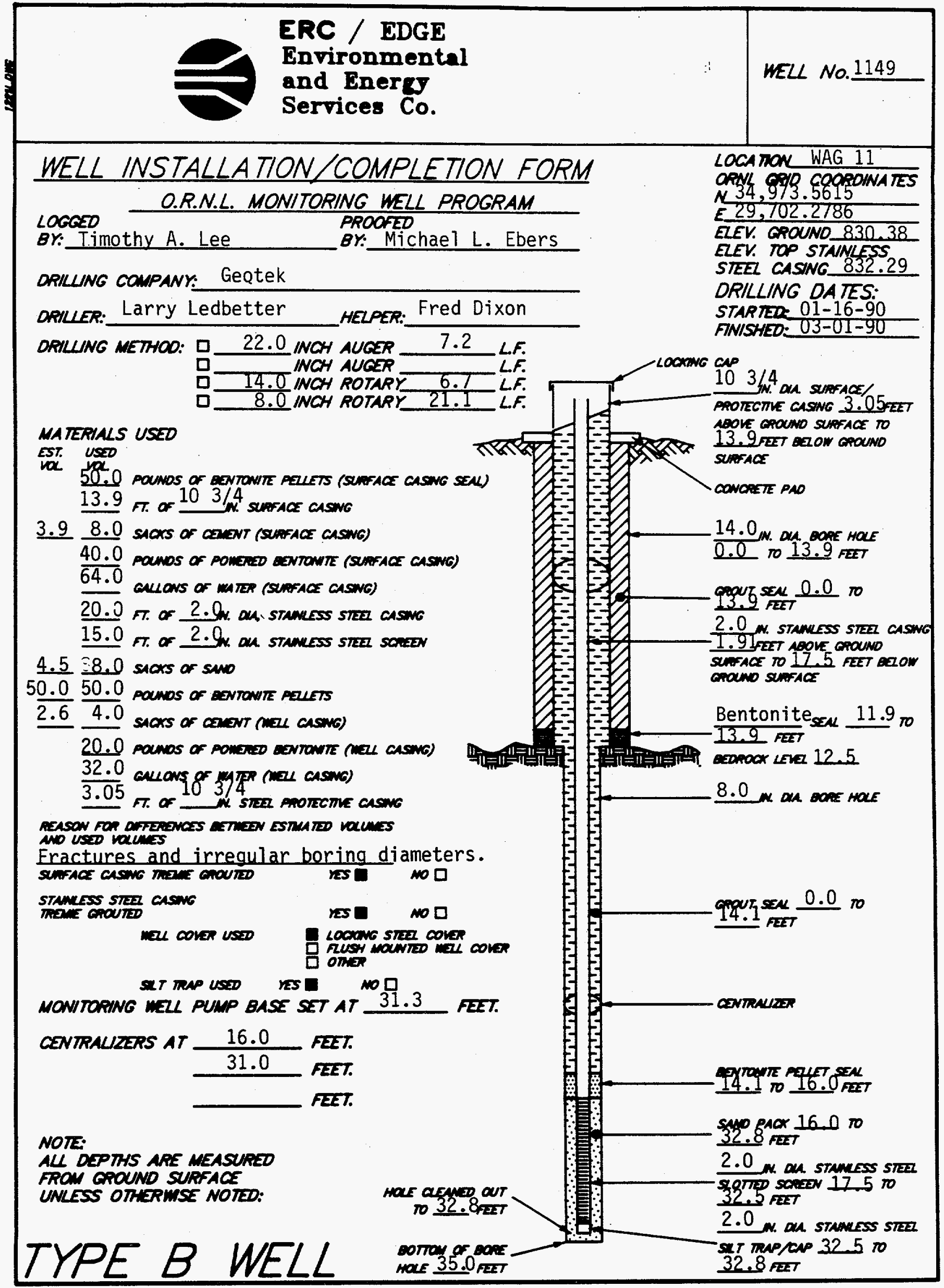

PACE 11 or 19 
ERC / EDGE

Environmental

WELL No._1149

and Energy

Services Co.

DA TE: $03-01-90$

\section{MONITORING WELL MATERIALS CERTIFICA TION}

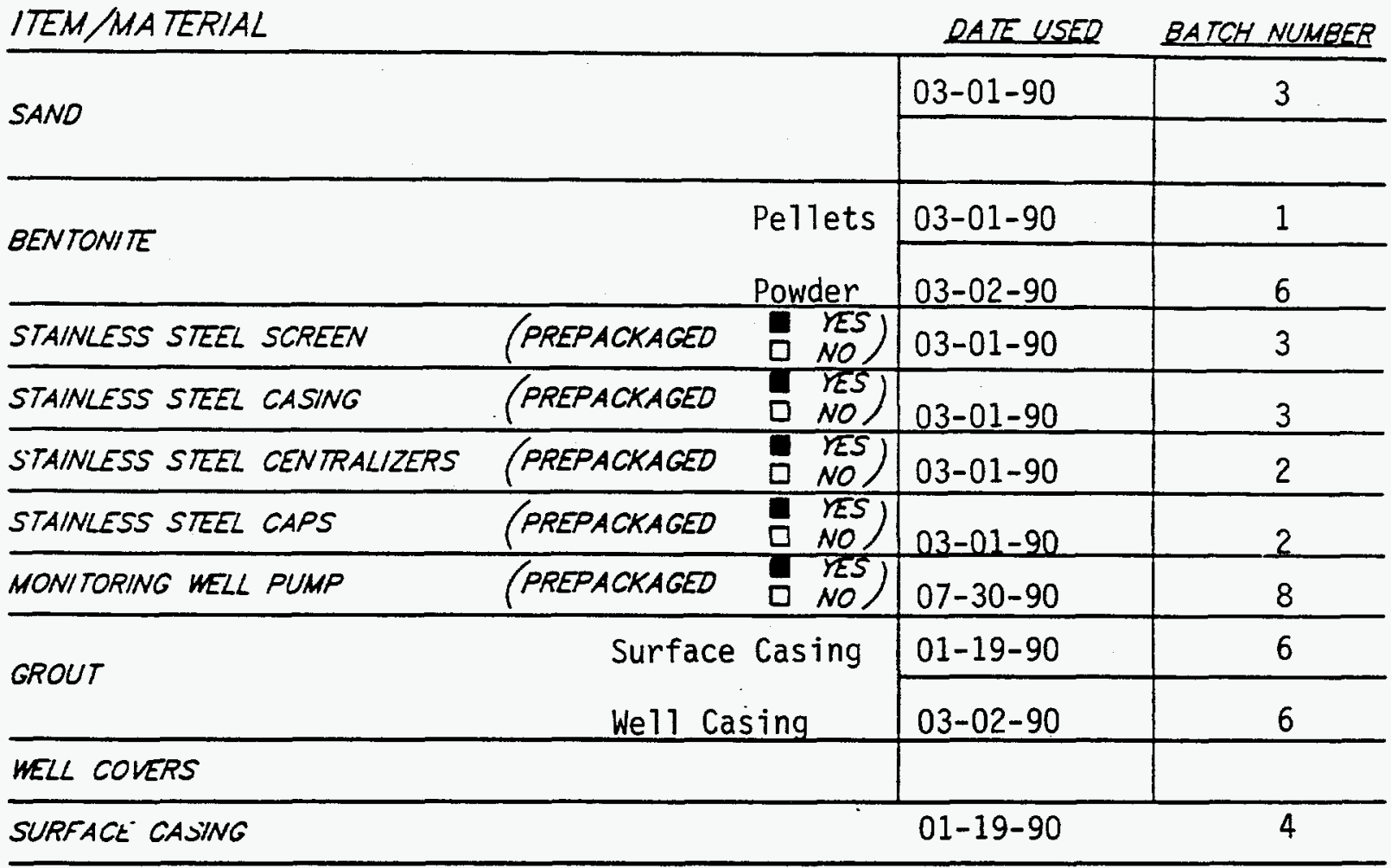

COMMENTS:

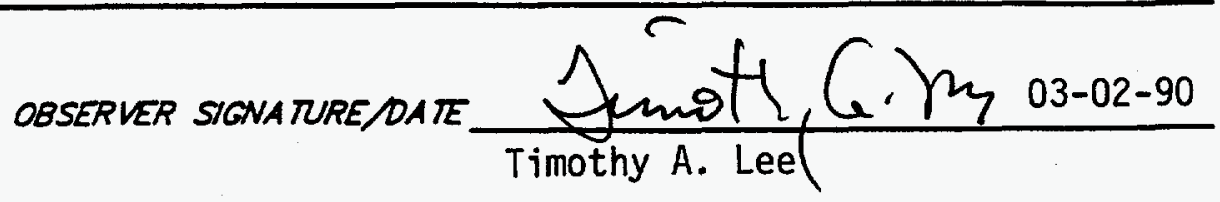




\section{POST-MELL COMPLETION CHECKLIST}

\section{POST-MELL COMPLETION TASKS}

1. MU SCRAPED FROW AUGERS SUMPLERS ANO ALL OTHER EOUIPMENT.

2. ALL WUD FRON RIG ANO EOUNIMENT SCRAPNGS ANO CUTINAS DISPOSED OF WN ACCOPDANCE WTH THE SPECYFCA ION" PROWOED.

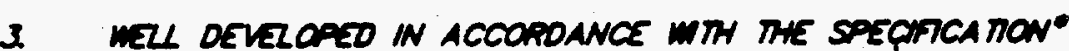
PRO WOED ANO DETAKS OF THE DEVZLOMENT ACHVT RECOROED.

4. DRULNG STE PROPERY QLEANED UP AFTER COMPLIANCE DA.E WIITALS COMPLETION OF MZL INSTALLATION.

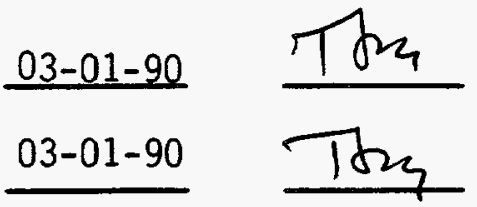

$07-30-90$

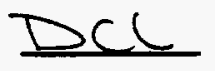

$03-01-90$

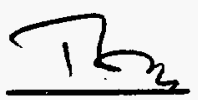

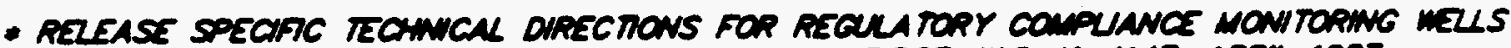

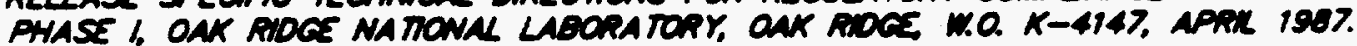

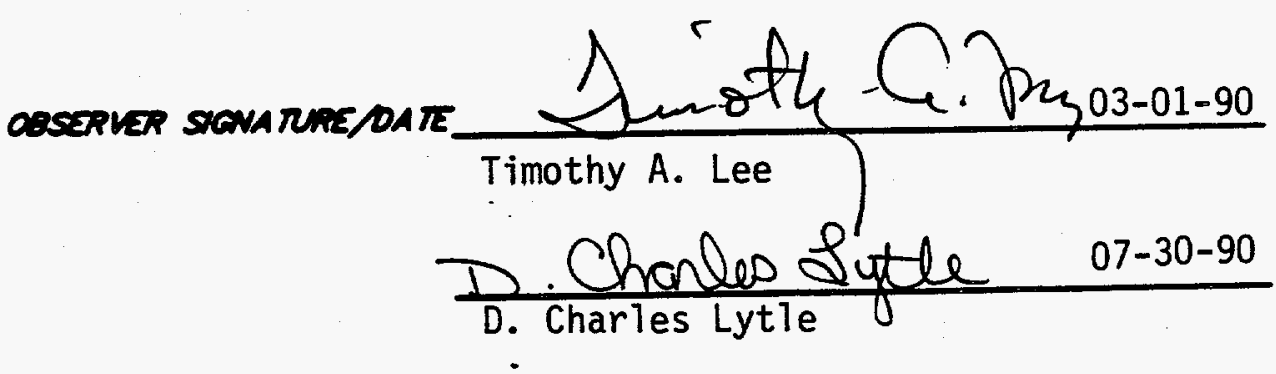




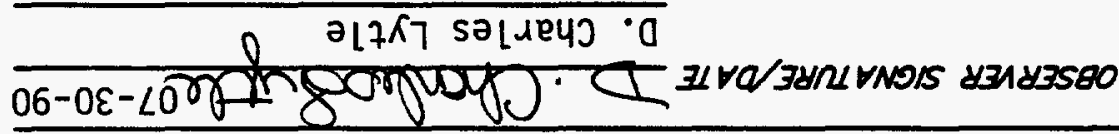

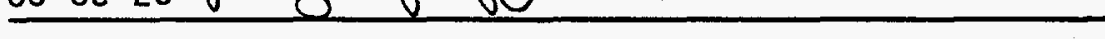

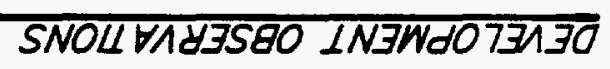

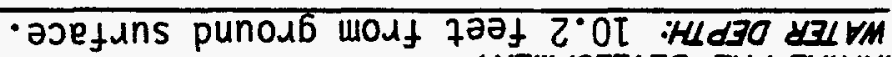
LNENDOTBU 30-33d TVUINI

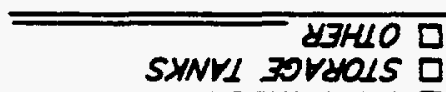

XON\& XNVI

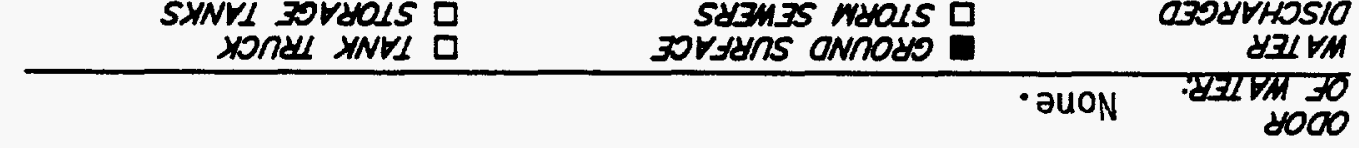

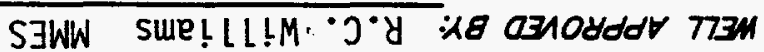

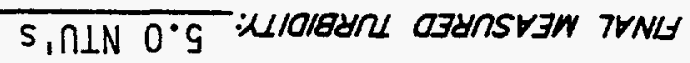

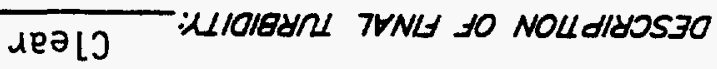
Kpno[J KLT4b!IS :HIOIaUR TVLINI to NoLd/YOS3O

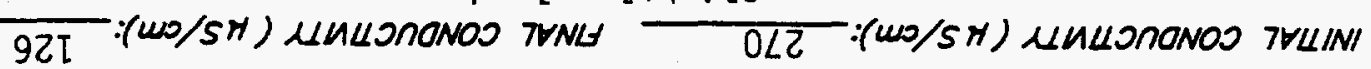
9.8 :HO 7HNL

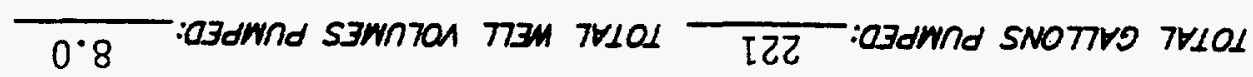

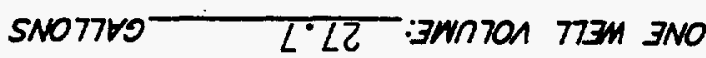

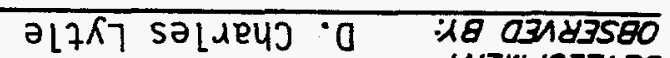
LNBWDO 33130

\begin{tabular}{|c|c|c|}
\hline & $06-0 \varepsilon-\angle 0$ & $\begin{array}{l}\text { ZIIVO DNIONG } \\
\text { INZWDOTZU } 30\end{array}$ \\
\hline$: 3 N 4$ & $06-0 \varepsilon-\angle 0$ & 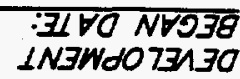 \\
\hline
\end{tabular}

6utdund pue 6ut6uns :IN3WdOT3 30 10 OOHLIW

$57 / 61301 N 3 W d 073130$

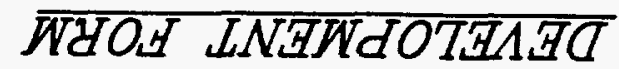
TTIM DNIAOLINOWT

II פHM $: N O U 6007$

66II:ON 773n 


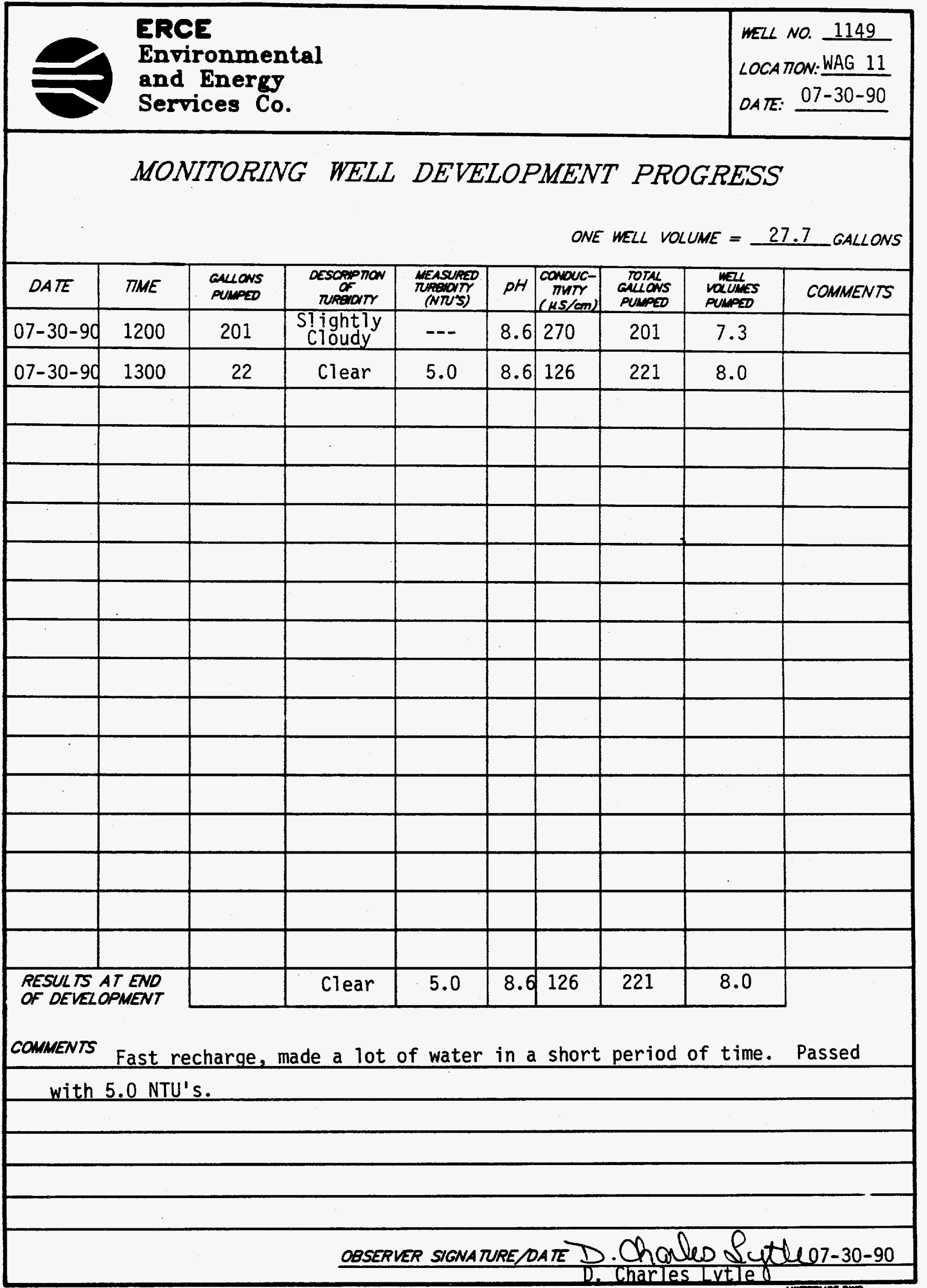




\section{HYDRAULIC CONDUCTIVTY CALCULATIONS}

PROGRAM SLUGT, VERSION 4.1, NOV. 1986

THIS PROGRAM CALCULATES MEAN TRANSMISSIVITIES FROM

SLUG-TEST DATA BASED ON TWO ANALYTICAL APPROACHES:

(1) METHOD OF COOPER, BREDEHOEFT AND PAPADOPULOS, 1967

(ARTICLE IN VOL. 3, NO.1 OF WRR ENTITLED

"RESPONSE OF A FINITE DIAMETER WELL TO AN INSTANTANEOUS CHARGE OF WATER")

(2) METHOD OF BOUWER AND RICE, 1976 (ARTICLE IN

VOL. 12, NO.3 OF WRR ENTITLED

"A SLUG TEST FOR DETERMINING HYDRAULIC CONDUCTIVITY

OF UNCONFINED AQUIFERS WITH COMPLETELY OR PARTIALLY PENETRATING WELLS")

WELI NO.: 1149

DATE OF TEST: $9-14-90$

PROJECT NO.: E221-002

CLIENT: MMES

SITE LOCATION: WAG-11

EDGE, INC. FIELD INVESTIGATOR: JAMES W. CARUTHERS

INPUT DATA ARE:

INNER CASING DIAMETER $=2.00$ INCHES

INNER SCREEN OR OPEN-HOLE DIAMETER $=2.00$ INCHES

DIAMETER OF DRILLED HOLE $=8.00$ INCHES

LENGTH OF SCREEN OR INTAKE PORTION $=15.00$ FEET

DEPTH FROM STATIC LEVEL TO BOTTOM OF SCREEN $=27.15$ FEET

THICKNESS OF SATURATED AQUIFER ZONE $=15.00$ FEET

DEPTH TO STATIC WATER LEVEL BELOW REF. POINT $=1.00$ FEET

ESTIMATED POROSITY OF GRAVEL PACK $=.20$

FALLING-HEAD INDEX $=1$ ("I" IF FALLING, "0" IF RISING)

NUMBER OF DEPTH-TIME DATA POINTS = 32

HO WAS COMPUTED FROM INTERCEPT OF PLOT OF LOG(H) VS. TIME

SUCCESSIVE COMPUTED

VALUES FOR HO

(FEET)

3.6130

3.7348 
Services Co.

\section{HYDRAULIC CONDUCTIVTY CALCULATIONS}

\begin{tabular}{|c|c|c|}
\hline$\left(\operatorname{SEC}^{\text {TIME }}\right)$ & $\begin{array}{l}\text { DEPTH TO WATER } \\
\text { (FEET) }\end{array}$ & $\begin{array}{l}\text { HEAD } \\
\text { (FEET) }\end{array}$ \\
\hline $\begin{array}{r}10.00 \\
20.00 \\
30.00 \\
40.00 \\
50.00 \\
60.00 \\
75.00 \\
90.00 \\
105.00 \\
120.00 \\
150.00 \\
180.00 \\
240.00 \\
300.00 \\
360.00 \\
420.00 \\
480.00 \\
540.00 \\
600.00 \\
720.00 \\
840.00 \\
960.00 \\
1080.00 \\
1200.00 \\
1320.00 \\
1440.00 \\
1560.00 \\
1680.00 \\
1800.00 \\
1920.00 \\
2040.00 \\
2160.00\end{array}$ & $\begin{array}{l}7.820 \\
7.240 \\
6.710 \\
6.290 \\
5.900 \\
5.580 \\
5.160 \\
4.790 \\
4.460 \\
4.190 \\
3.740 \\
3.380 \\
2.860 \\
2.490 \\
2.230 \\
2.050 \\
1.900 \\
1.770 \\
1.670 \\
1.520 \\
1.420 \\
1.360 \\
1.300 \\
1.260 \\
1.210 \\
1.190 \\
1.170 \\
1.170 \\
1.140 \\
1.130 \\
1.120 \\
1.120\end{array}$ & $\begin{array}{l}6.820 \\
6.240 \\
5.710 \\
5.290 \\
4.900 \\
4.580 \\
4.160 \\
3.790 \\
3.460 \\
3.190 \\
2.740 \\
2.380 \\
1.860 \\
1.490 \\
1.230 \\
1.050 \\
.900 \\
.770 \\
.670 \\
.520 \\
.420 \\
.360 \\
.300 \\
.260 \\
.210 \\
.190 \\
.170 \\
.170 \\
.140 \\
.130 \\
.120 \\
.120\end{array}$ \\
\hline
\end{tabular}




\section{HYDRAULIC CONDUCTIVTY CALCULATIONS}

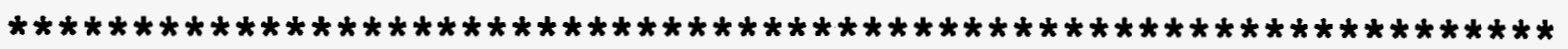
METHOD OF BOUWER AND RICE

COMPUTED RESULTS USING DIAMETER OF DRILLED HOLE:

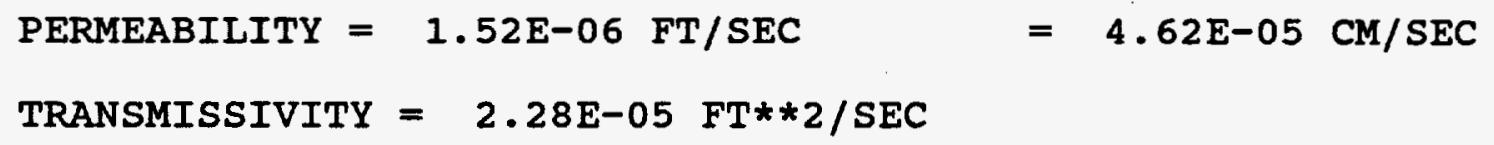


ERC / EDGE

Environmental

and Energy

WELL NO. 1149

Services Co.

\section{HYORAULIC CONDUCTIVTY CALCULATIONS}

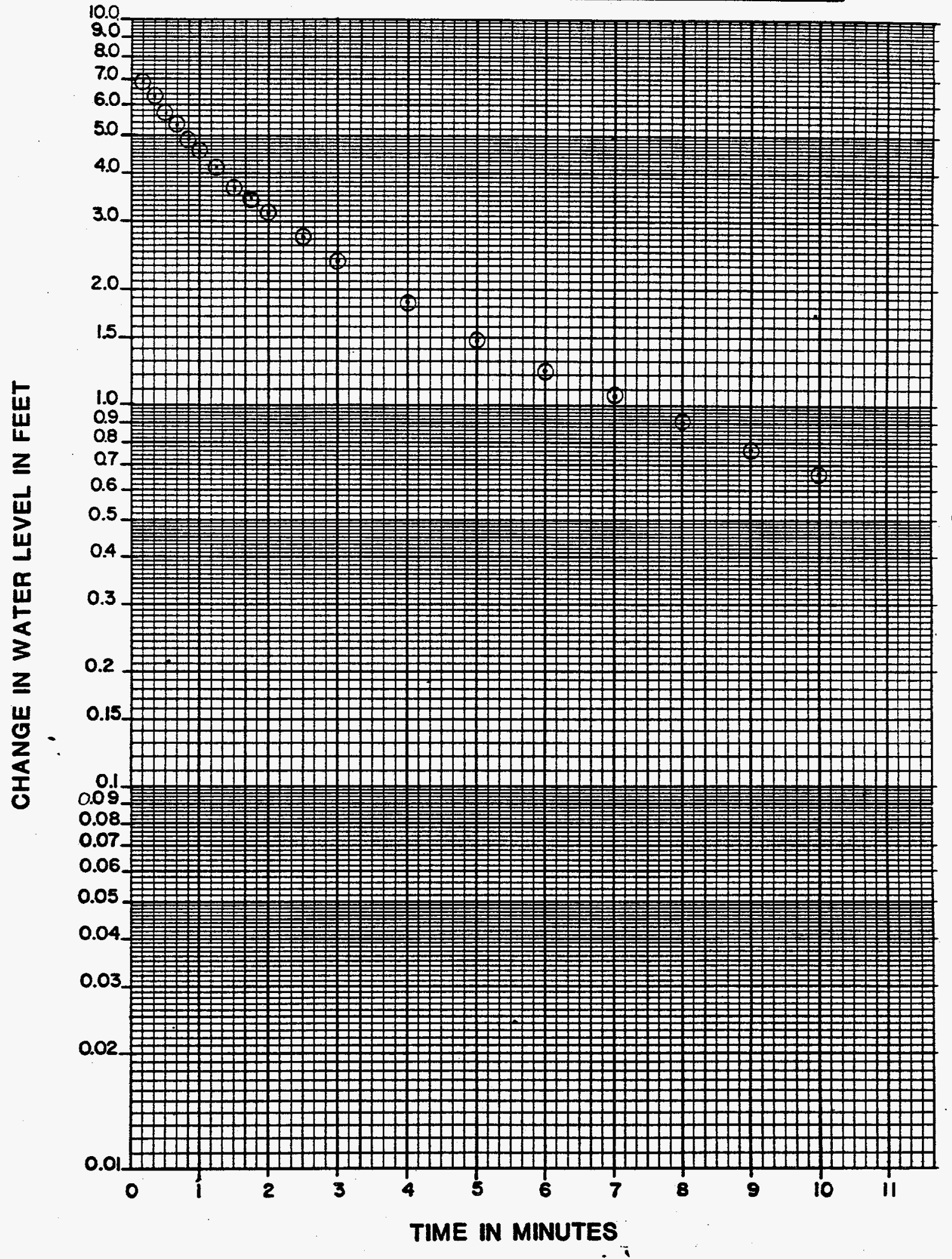

PACE 12 of 19 
ERCE

Environmental

and Energy

WELL NO. 1246

Services Co.

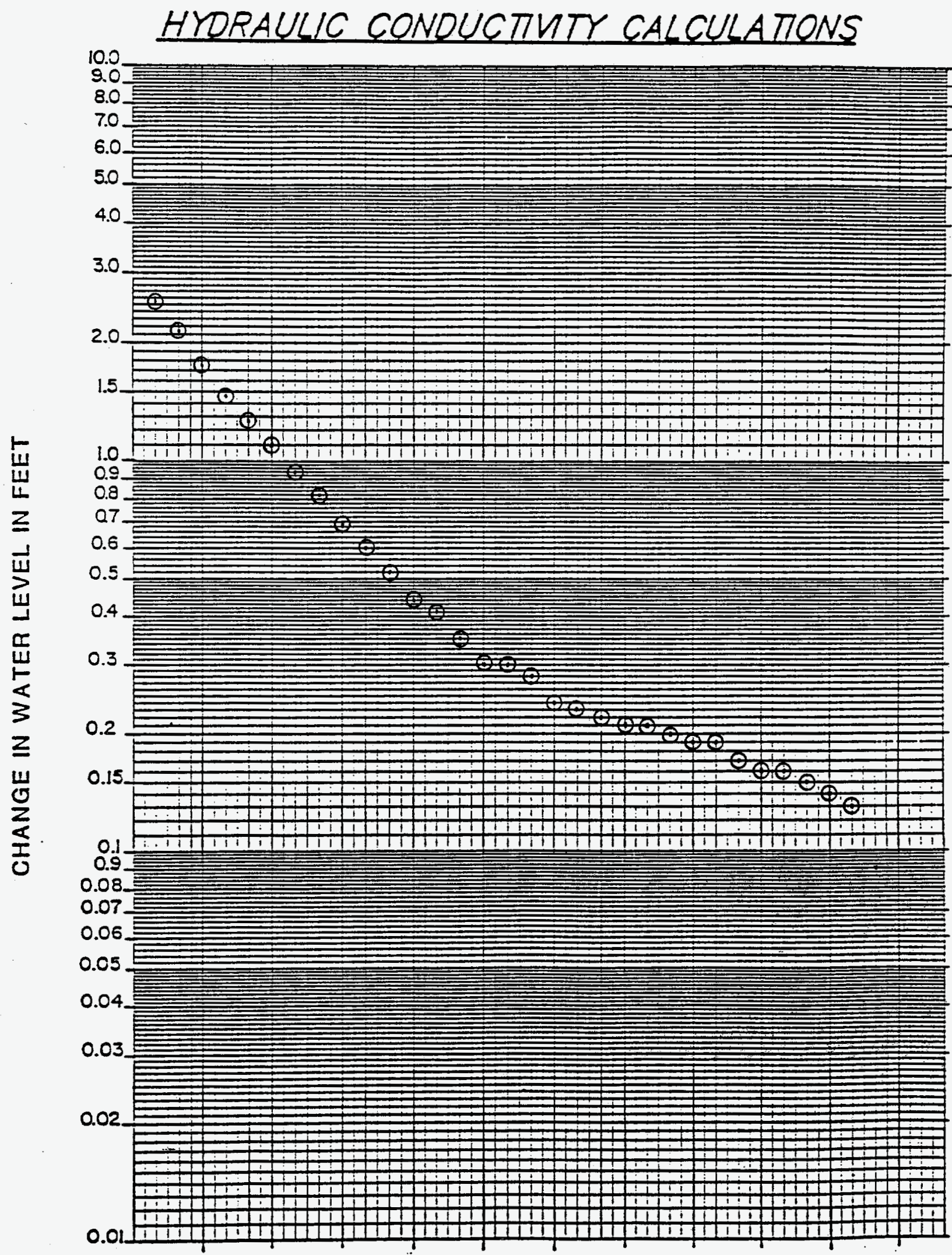
15
30
45
60
TIME IN SEC. 


\subsection{General Information}

\subsection{Nell Location}

Monitoring well number 1147 is located in WAG 11. It is located in the northeastern portion of "White wing scrap Yard" or WAG 11. The location is shown on ORNL drawing number C3E20004A075. Survey coordinates for this well are $\mathrm{N} 35,696.4970, \mathrm{E} 28,354.4126$ (X-10 grid) or latitude $35^{\circ}-57^{\prime}-13.36^{\prime \prime}$ and longitude $84^{\circ}-21^{\prime}-00.48^{\prime \prime}$. Coordinate data were provided by Martin Marietta Energy systems. The method used for conversion from $x-10$ grid to Tennessee-Lambert state Plane coordinates came from the publication "Tennessee Valley Authority Data Services Branch and Mapping Services Branch, Oak Ridge, Tennessee, DOE Plant Control, November 6, 1985, Field Book: ESS-3115, pp. 1-20." The latitude and longitude were calculated by Adams craft Herz Walker Engineering, Inc., using methods from the U.S. Coast and Geodetic survey Publication 62-4, "State Plane Coordinates by Automatic Data Processing."

\subsection{Drilling Information}

Well number 1147 was drilled by Geotek Engineering Company. An Ingersoll Rand T-4 rig was used to drill this boring for monitor well installation under operation of Larry Ledbetter with the assistance of Fred Dixon. Drilling commenced on 1-4-90 and was finished on 1-29-90. Paragraph 2.4.1 includes a detailed discussion of the well installation and a well schematic is included on the well installation/completion form. A synopsis of the 
drilling activity follows. This information was typed directly from field notes and was edited only when necessary for clarification.

1-4-90 Mobilize rig to staked location and set up on plastic sheeting. Augered from surface to 7.0 feet using a 22.0-inch auger. Set 6.0 feet of 14.0-inch decontaminated steel div ter casing. The rig was moved from location.

1-5-90 The diverter casing was grouted wit.. 5 sacks cement.

1-8-90 The rig moved over hole and augered to refusal at 39.5 feet with a 14.5 -inch auger.

1-9-90 The boring was deepened from 39.5 feet to 45.8 feet using air rotary method with a 14.5-inch air rotary tricone bit. Set 45.8 feet of 10 3/4-inch decontaminated steel surface casing and sealed with bentonite seal. Move rig from location.

1-10-90 Grouted surface casing annulus with 10 sacks of cement.

1-25-90 Move rig over hole.

1-26-90 Deepened boring from 45.8 feet to 97.9 feet using an 8.0-inch air rotary tricone bit.

1-29-90 Set stainless steel 4-inch screen and casing with sand pack and bentonite seal.

1-30-90 Grouted well casing with 19 sacks cement.

This well was logged by ERC Environmental and Energy Services Co., Inc., hydrogeologist Timothy A. Lee. All well construction materials and supplies were from Martin Marietta Energy Systems approved batches. The batch origin of individual items is shown on the included Monitoring Well Materials Certification form. 


\subsection{Technical Information}

\subsection{Decontamination Procedures}

The drilling rig, down hole tools, surface casing, stainless steel screen, stainless steel casing, centralizers, and stainless steel silt trap underwent the cleaning decontamination procedures outlined in the drilling specifications (Release Specific Technical Directions for Regulatory Compliance Monitoring Wells Phase 1, Oak Ridge National Laboratory, Oak Ridge, w.O., K-4147, April 1987, pgs, 2-4). A checklist of the cleaned materials is included with this data package.

\subsection{Geology}

The northeastern half of WAG 11 is underlain by Chickamauga Limestone. The Rome Formation underlies the southwestern half of WAG 11 . The Chickamauga Limestone is brought into contact with the Rome Formation by the White oak Mountain thrust fault, the trace of which bisects WAG 11 from northwest to southeast. The lowermost beds of the chickamauga are composed of thin bentonitic beds, gray clay shale, and maroon to gray calcareous siltstone. The majority of the Chickamauga, approximately 1,500' thick, is a dominantly gray, dense, finely crystalline, thin bedded limestone with varying amounts of chert. The uppermost beds consist of yellow and maroon calcareous siltstone and blue-gray limestone. The Rome Formation is composed of interbedded sandstone, siltstone, shale and locally, dolomite. 


\section{3 sample Collection}

One soil sample was collected during drilling, placed in an I-CHEM specialty cleaned glass container, sealed and submitted to Sample Receiving, Analytical Chemistry Division, Bldg. 4500s, ORNL. A chain of custody forms for this sample is included with this data package. Soil sample 1139501 was collected in the split spoon interval from $6.2^{\prime}$ to $6.5^{\prime}$ on $1-19-90$.

A drill water sample was collected from the water pump on the drill rig on 1-29-90. Analytical results for the Ingersoll Rand T-4 drill water samples described above can be obtained from the Remedial Action Program data base at ORNL.

The Ingersoll Rand T-4 compressed air was sampled with a cloth filter inserted between drill rods on 1-29-90. The sample was examined with an ultraviolet light for the presence of hydrocarbons. The filter showed no detectable signs of hydrocarbons.

\subsection{Installation and Development}

\subsubsection{Installation}

This was a Type B well. A 22.0-inch diameter boring was augered from ground surface to 6.0 feet. A $151 / 4$-inch diverter casing was installed from surface to 6.0 feet below ground surface and grouted in place. A 14.0-inch diameter boring was augered from 6.0 feet to 39.5 feet (auger refusal). The boring was then extended past the refusal depth with a 14.0-inch air rotary tricone roller bit from 0.0 feet to 45.8 feet. A 10.0-inch diameter 
string of decontaminated steel surface casing was installed from 0.0 feet to 45.8 feet, sealed with a 2.0 foot bentonite pellet layer from 43.8 feet to 45.8 feet, and tremie grouted in place. The surface casing minimizes potential cross contamination between the regolith and bedrock water bearing zones. After the surface casing was installed, the air rotary method was used to drill an 8-inch diameter boring to a total depth of 97.9 feet. A 4-inch diameter stainless steel screen with threaded bottom cap was installed from 77.7 feet to 97.9 feet. A 4-inch diameter stainless steel casing was installed from the top of the screen at 7.77 feet and extended 2.2 feet above ground surface. A sandpack was then tremied into the annular space from 73.5 to 97.9 feet, with a 1.3 foot bentonite pellet seal poured into the annular space above the sandpack from 72.2 to 73.5 feet. The annular space from the top of the bentonite seal to the surface was tremie grouted with a cement/bentonite slurry. A detailed schematic of the well is included on the well installation/completion form.

\subsubsection{Well Development}

Well number 1147 was developed to remove drill cuttings, silt, and other fines. The monitoring was developed using a Geoguard pump with an air compressor. All pumps were cleaned prior to use according to specified cleaning procedures (see Paragraph 2.1). The well was developed until a measured total of 550 gallons of water had been evacuated and the clarity of the discharge water was approved by the company representative. The final 
ERC / EDGE

Environmental

and Energy

Services Co.

turbidity value measured at completion was 1.0 NTU's. A development form showing the exact method of development and other pertinent data is appended.

\subsubsection{Installation of Dedicated Monitoring Well Pump}

After the well was developed, a Geoguard Model No. 5614 dedicated monitoring well pump was installed on $8 / 10 / 90$ at a depth of 93.3 feet below ground surface. These pumps are decontaminated at American sigma and are sent prepackaged. A copy of the pump certification is kept on file at ORNL.

\subsection{Hydraulic Conductivity Testing}

Well number 1147 was tested for the determination of hydraulic conductivity of the aquifer in the vicinity of the well screen. This was accomplished by instantaneously removing a known quantity of water from the monitoring well and measuring the recovery of the water level over time. The changing water levels were measured using a Druck 15 psi pressure transducer and an Omnidata Datapod II data recorder. The hydraulic conductivity value of $9.18 \times 10^{-5} \mathrm{~cm} / \mathrm{second}$ (shown as permeability on the hydraulic conductivity calculations printout attached) was calculated using the Bouwer and Rice method. A computer printout of the hydraulic conductivity calculations is included in this data package. 
ERC / EDGE

Environmental

and Energy

WELL No.11 147

Services Co.

\section{PRE-DRILLING CHECKLIST FOR MONITORING WELLS}

\section{PRE-ORILLING TASKS}

1. EXCAVATION PERMIT OBTAINED.

2. ALL EOUIPMENT HAS BEEN CLEANED BEFORE DRILLING.

3o. SCREEN AND CASINGS HAVE BEEN WASHED, STEAMED, RINSED WTH DE-IONIZED OR DISTILLED WATER, RINSED WTH ISOPROPV ALCOHOL WRAPPED WTH PROTECTVE COVERING AND STORED OFF THE GROUND.

36. PRE-PACKAGED SCREENS, CASINGS AND CENTRALIZERS WERE USED.

4. WORK AREA FOR SAMPLE EXAMINA IION COVERED WTH CLEAN POL YETHKENE.

5. CLEAN KNIVES, GLOVES, SAMPLE JARS AND LABELS ON-HAND.

6. POL VETHYENE COVER IN PLACE OVER HOLE.

7. AIR ROTARY COMPRESSED AIR SAMPLED.

AOOITONAL NOTES/OBSERVATIONS:

RESULTS: No hydrocarbons detected under ultra violet light.

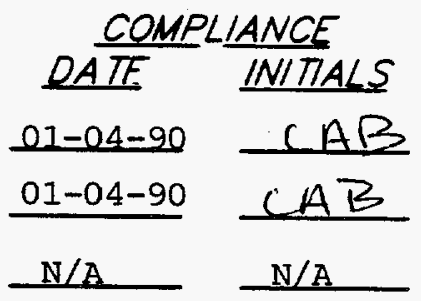

$\underline{01-29-90} \subset A B$

01-04-90 CAB

$01-04-90<A B$

01-04-90 C.AS

01-29-90:T7m

\section{Resuls: No hydrocarbons detected under ultra violet light.}


ERC / EDGE

Environmental

and Energy

Services Co.

\section{DECONTAMINATION CHECKLIST \\ DRILLING EQUIPMENT}

\begin{tabular}{|c|c|c|c|c|c|}
\hline EQUIPMENT & SCRAPE & $\begin{array}{l}\text { STEAN } \\
\text { CLEAN } \\
\end{array}$ & $\begin{array}{l}\text { STEAM } \\
\text { RINSE }\end{array}$ & $\begin{array}{c}\text { ISOPROPY } \\
\text { ALCOHOL } \\
\text { RINSE }\end{array}$ & $\begin{array}{c}\text { OEIONIZED } \\
\text { WATER } \\
\text { RINSE }\end{array}$ \\
\hline$R / G$ & $x$ & $x$ & $x$ & $N / A$ & $N / A$ \\
\hline AUGERS & $x$ & $x$ & $x$ & $x$ & $x$ \\
\hline BITS & $x$ & $x$ & $X$ & $X$ & $x$ \\
\hline RODS & $x$ & $x$ & $X$ & $x$ & $x$ \\
\hline SAMPLERS & $x$ & $x$ & $x$ & $x$ & $x$ \\
\hline PIPES & $X$ & $x$ & $x$ & $x$ & $x$ \\
\hline WORK TOOLS & $x$ & $x$ & $x$ & $x$ & $x$ \\
\hline AUGER PINS & $x$ & $x$ & $x$ & $x$ & $x$ \\
\hline & & & & & \\
\hline & & & & & \\
\hline & & & & & \\
\hline & & & & & \\
\hline
\end{tabular}

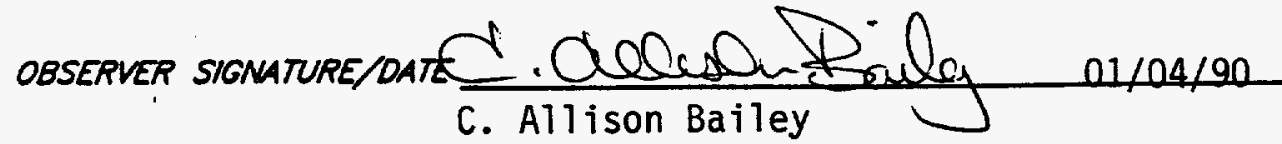




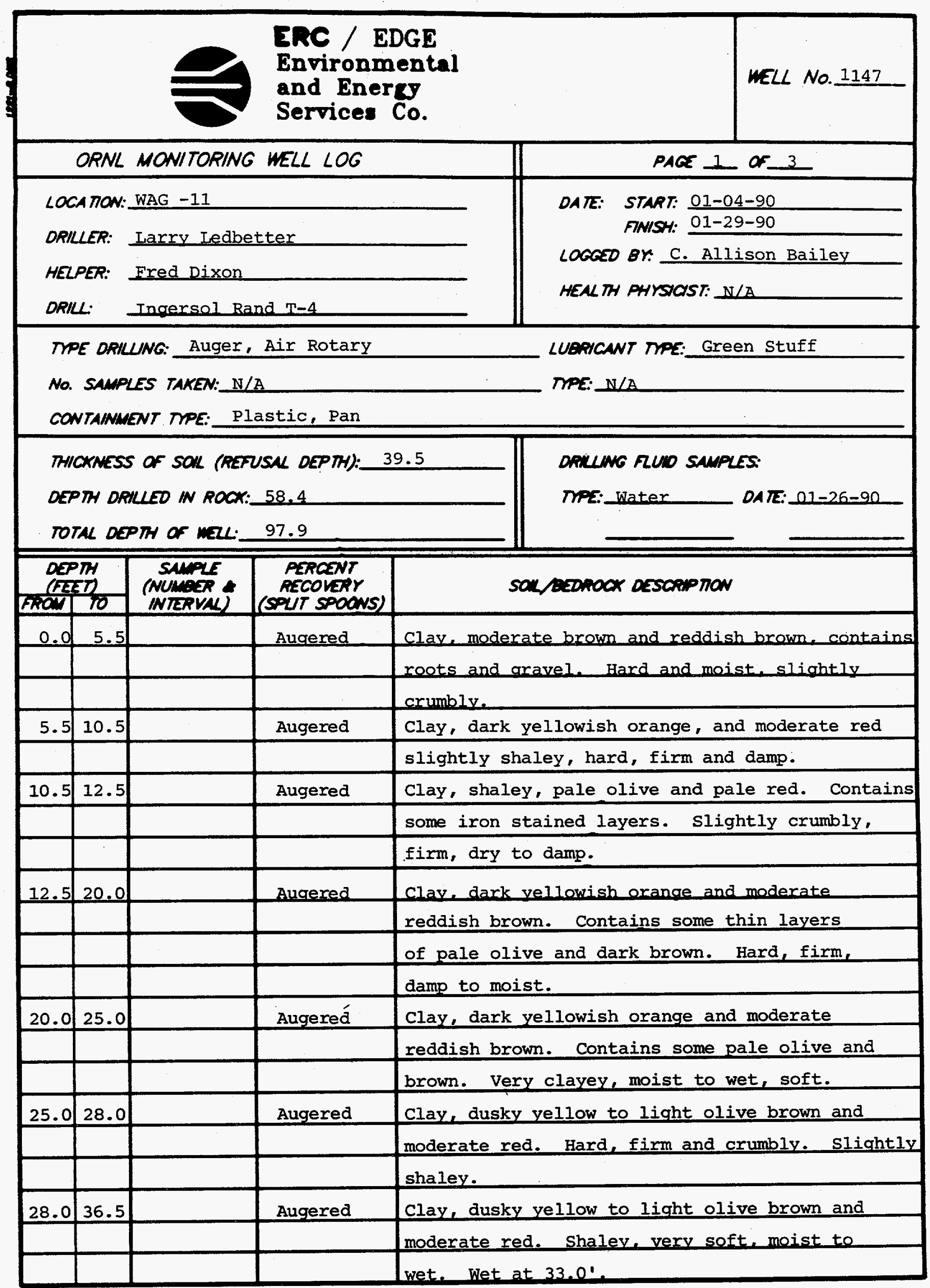




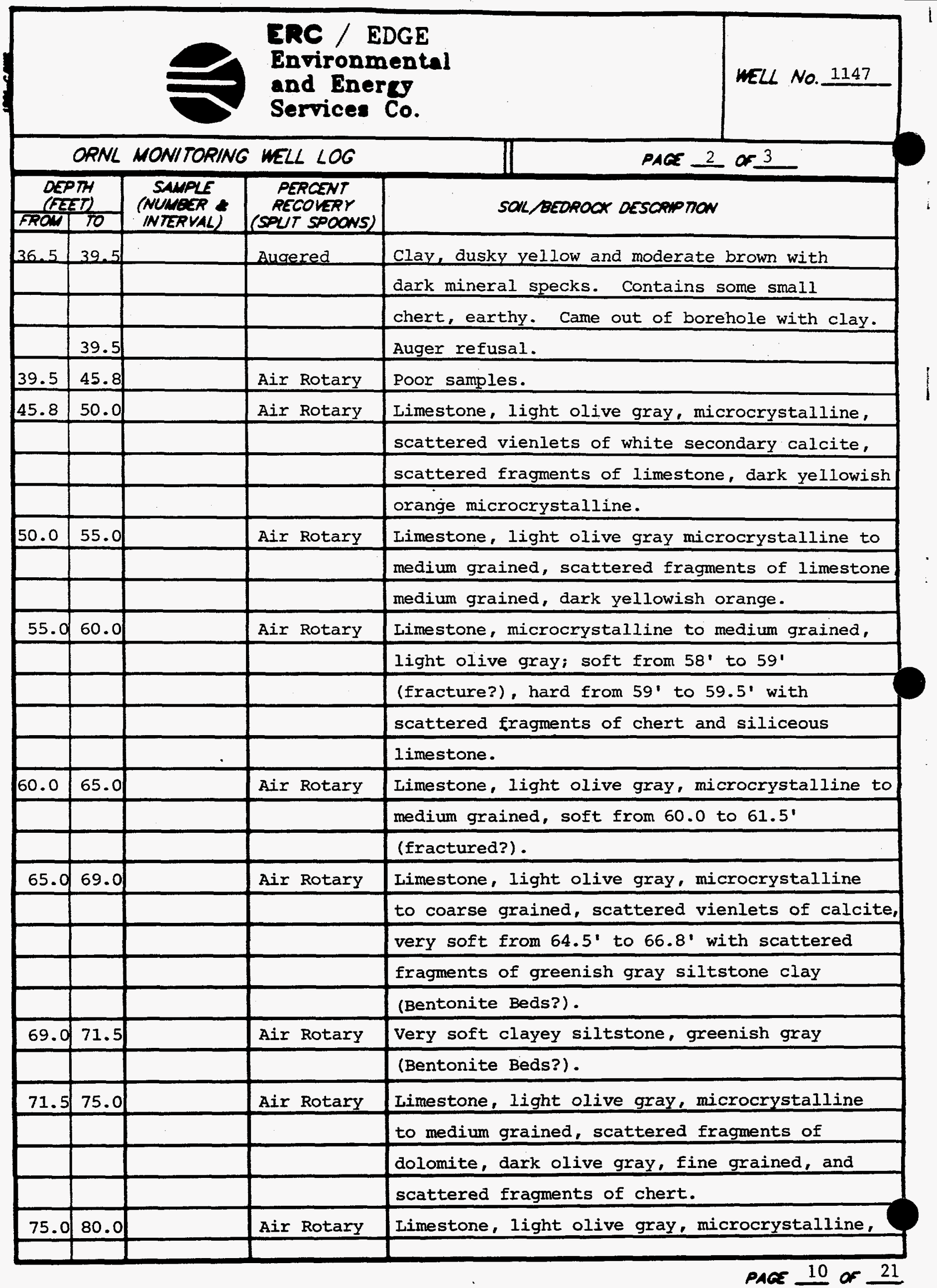




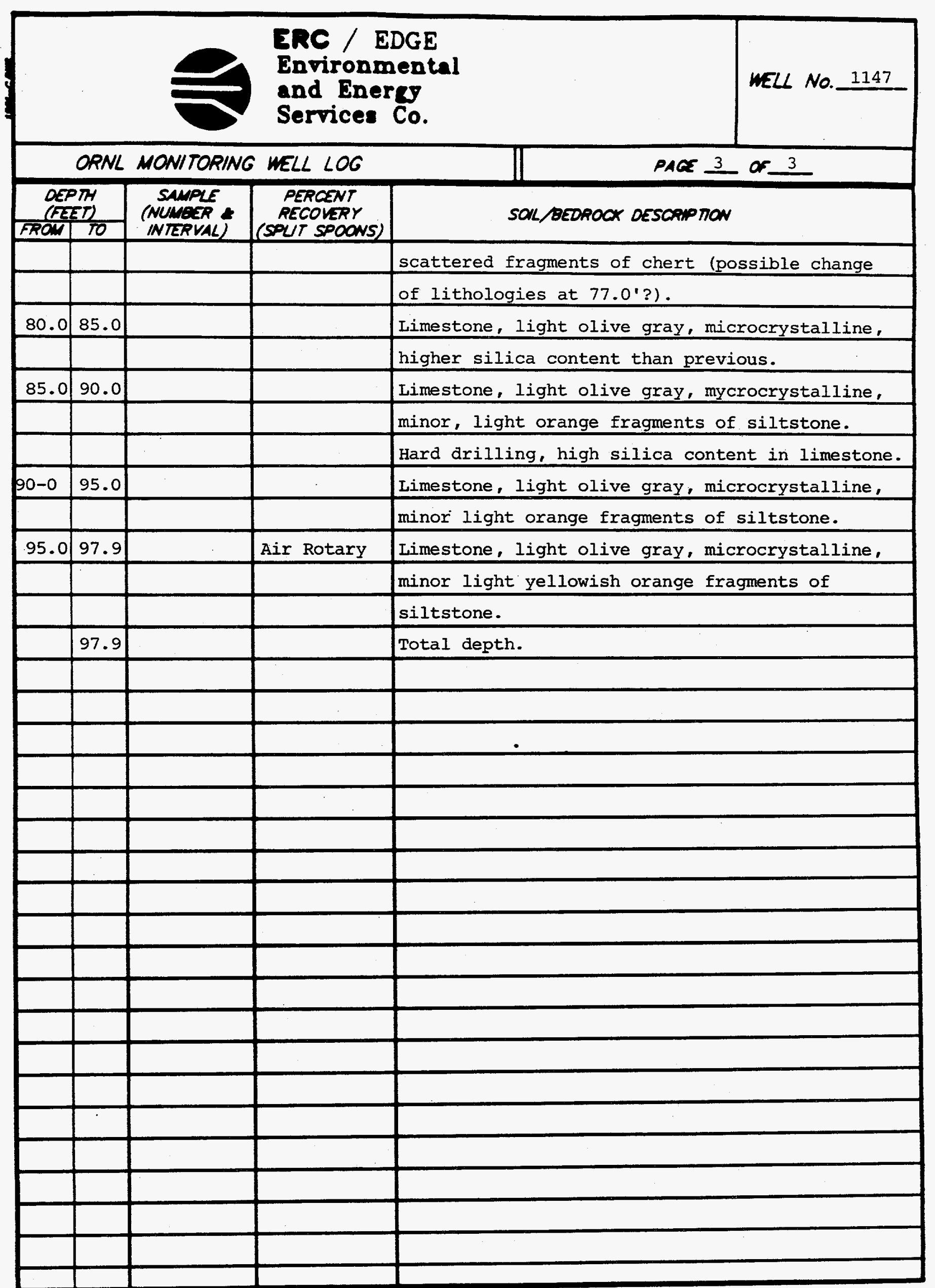




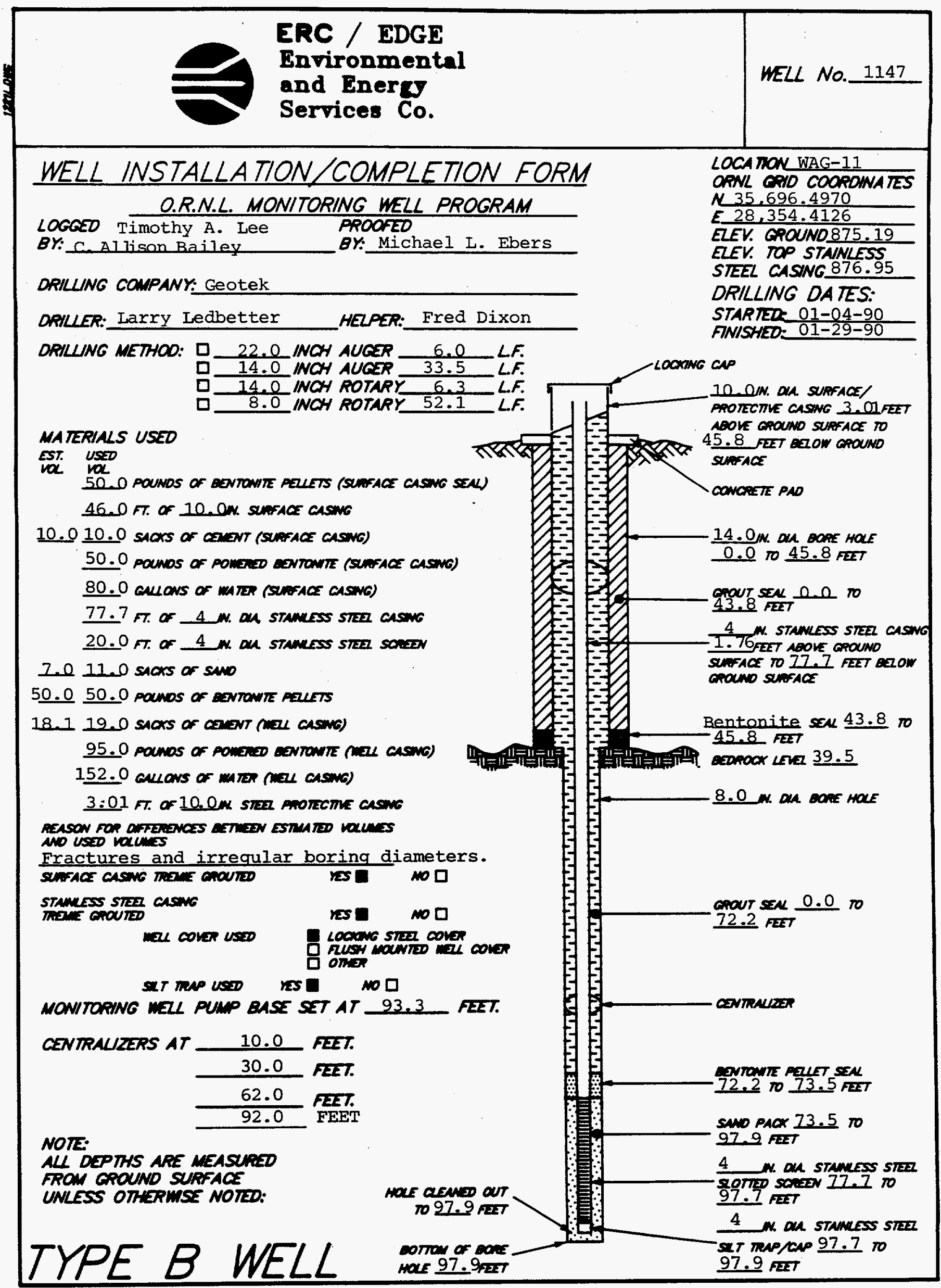


ERC / EDGE

Environmental

WELL NO. 1147

and Energy

Services Co.

\section{MONITORING WELL MATERIALS \\ CERTIFICATION}

ITEM/MA TERIAL

DATE USED BATCH NUMBER

SAND

BENTONITE

Powder

STAINLESS STEEL SCREEN

STAINLESS STEEL CASING

STAINLESS STEEL CENTRALIZERS

STAINLESS STEEL CAPS

MONITORING WELL PUMP

GROUT

Surface Casing

(PREPACKAGED

(PREPACKAGED

(PREPACKAGED

(PREPACKAGED

(PREPACKAGED

\begin{tabular}{|c|c|c|}
\hline & DATE USED & BATCH NUMBER \\
\hline & $01-29-90$ & 2 \\
\hline owder & $01-09-90$ & 4 \\
\hline ellets & $01-29-90$ & 1 \\
\hline$\left(\begin{array}{c}\text { YES } \\
\text { NO }\end{array}\right.$ & $01-29-90$ & 3 \\
\hline$\left(\begin{array}{cc}\text { YES } \\
\text { NO }\end{array}\right.$ & $01-29-90$ & 3 \\
\hline $\begin{array}{cc}\text { NES } \\
\text { NO }\end{array}$ & $01-29-90$ & 2 \\
\hline $\begin{array}{c}\text { YES } \\
\text { NO }\end{array}$ & $01-29-90$ & 2 \\
\hline $\begin{array}{c}\text { VES } \\
\square \text { NO }\end{array}$ & $08-10-90$ & 8 \\
\hline \multirow[t]{2}{*}{ Casing } & $01-09-90$ & 5 \\
\hline & $01-29-90$ & 5 \\
\hline & $01-09-90$ & $\begin{array}{l}\text { MMES } \\
\text { Stores }\end{array}$ \\
\hline
\end{tabular}

COMMENTS:

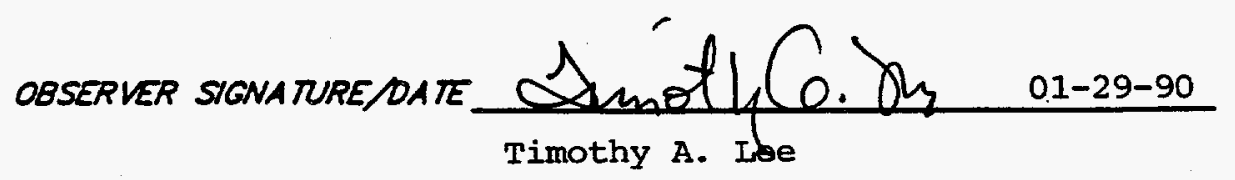

PAGE 13 of 21. 


\section{POST-MELL COMPLETION CHECKLIST}

\section{POST-WELL COMPLETON TASKS}

1. MUD SCRAPCD FROW AUGERS SMMPLERS ANO ALI

COMPIIANCE

DA.E INITALS

\section{OTHER EQUIPIENT.}

2. ALL WUO FRON RIG AND EQUIPMENT SORAPINGS NNO CUTMNOS OSSPOSEO OF $W$ ACCOROANCE MTH THE SPECARCA IION PROWOED.

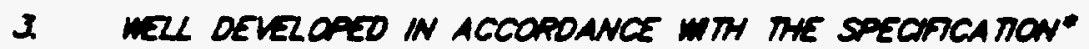
PROVOED ANO DETAKS OF THE OEVZLOPENT ACTUTY RECOROSO.

4. DRULNG STE PROPERLY QLANED UP AFTRR

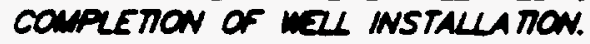

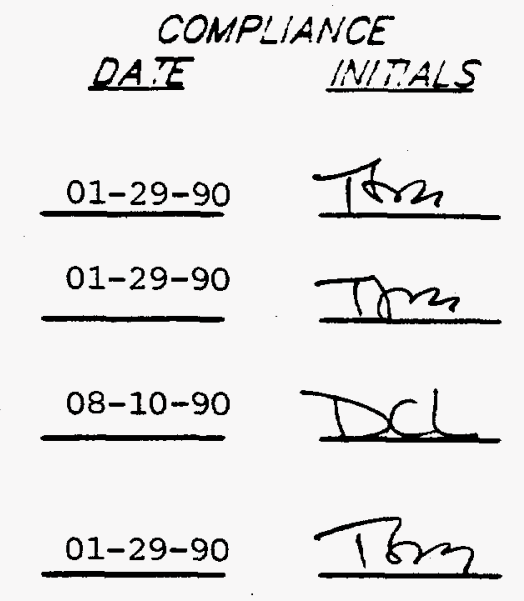

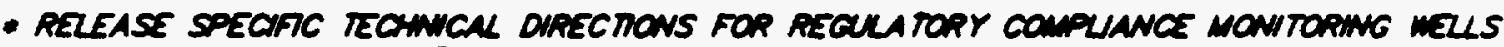

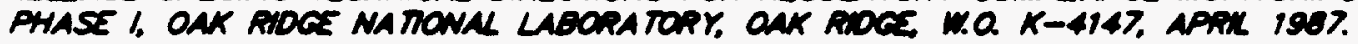

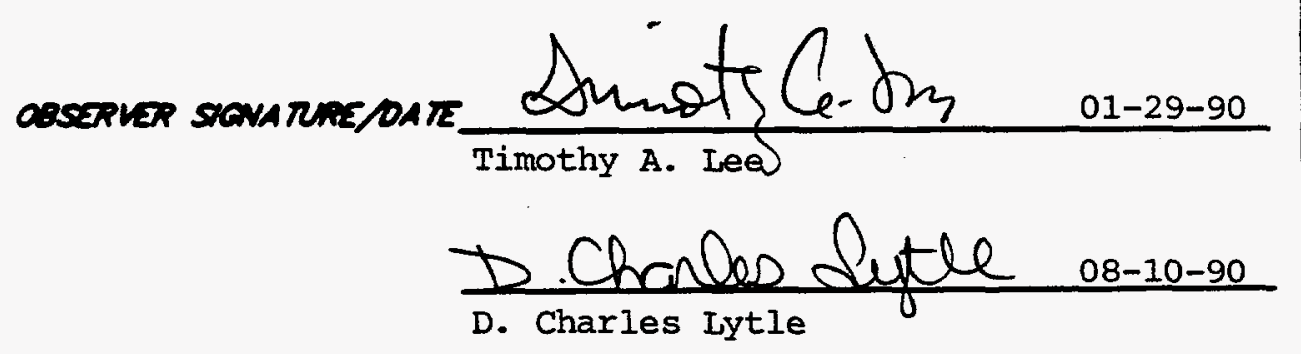




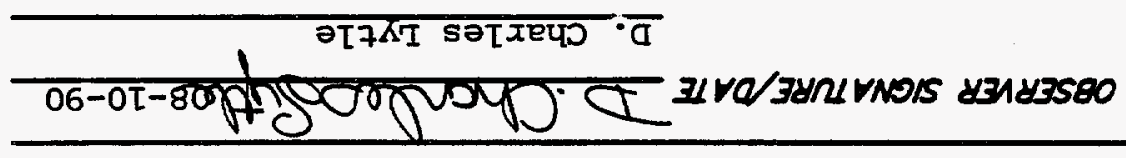

SNOLV1D3S80 IN3WDO73130

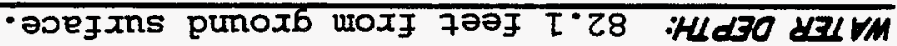
LNEMOOZZ430-3Xd $71 U$ IN

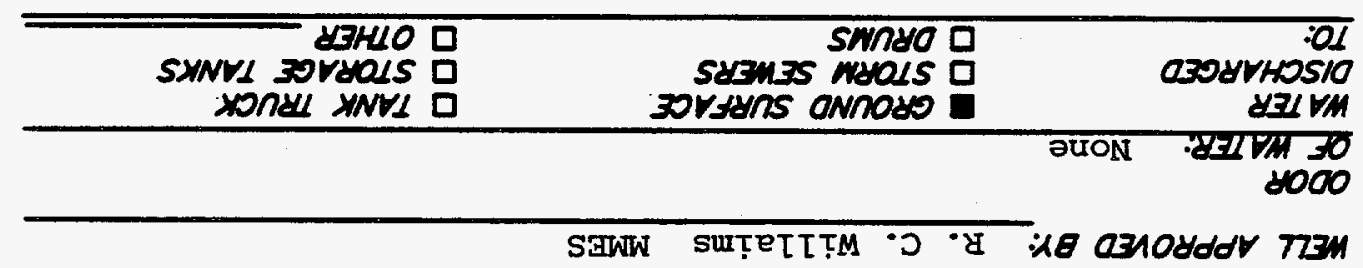

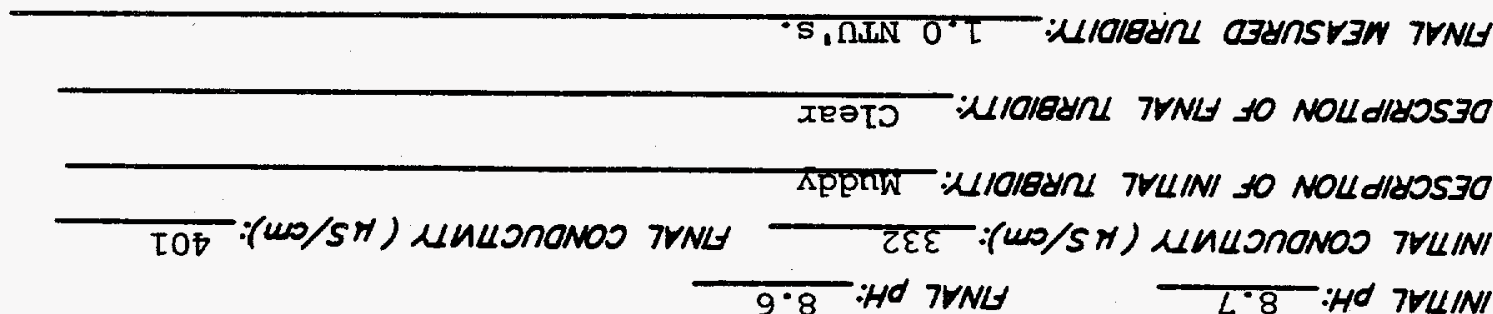

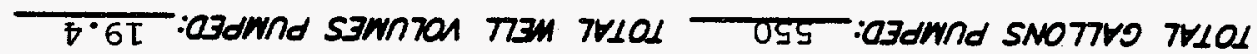
SNO77V9

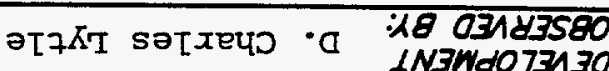
06-0I-80 TIVO ONIONG $06-\varepsilon 0-80$ :31 $1 N 3 N 2073130$

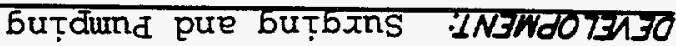
so OOH $3 W$

$57 / 71301 N 3 W d 073130$

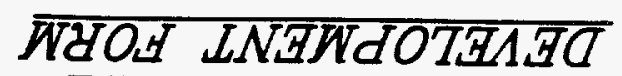

TTZM DNIZOLINOW

IT פसM $: N O U \forall O O 7$

- os sooţasos

LEIT ON 773 M

alsoug pure

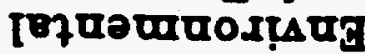

3043 


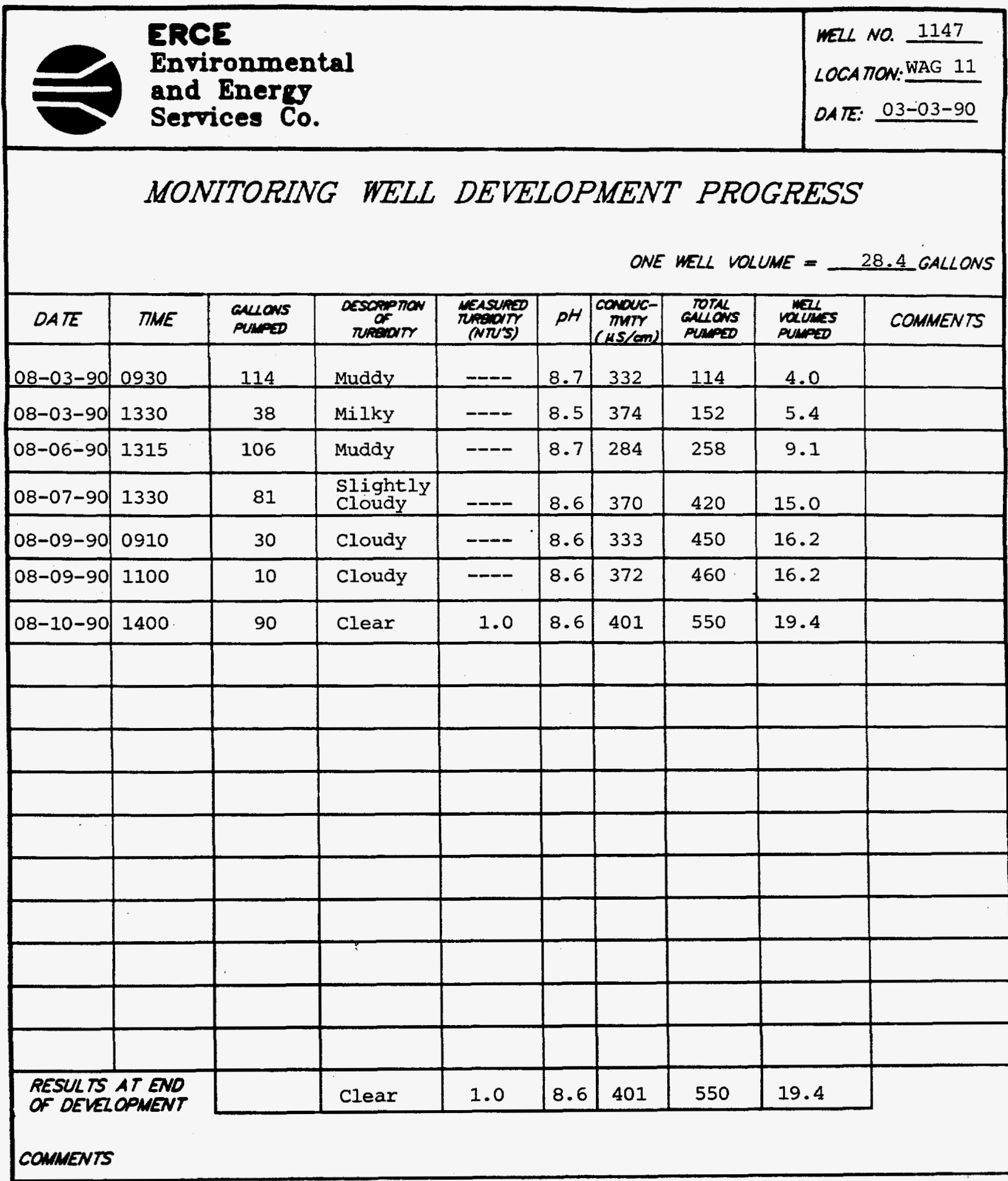




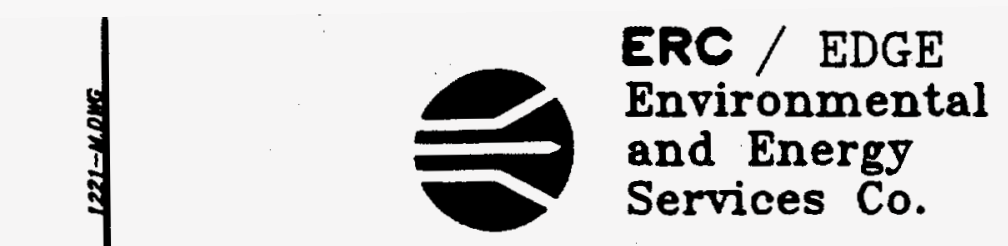

\section{HYORAULIC CONDUCTIVTY CALCULATIONS}

PROGRAM SLUGT, VERSION 4.1, NOV. 1986

THIS PROGRAM CALCULATES MEAN TRANSMISSIVITIES FROM SLUG-TEST DATA BASED ON TWO ANALYTICAL APPROACHES:

(1) METHOD OF COOPER, BREDEHOEFT AND PAPADOPULOS, 1967 (ARTICLE IN VOL.3, NO. 1 OF WRR ENTITLED "RESPONSE OF A FINITE DIAMETER WELL TO AN INSTANTANEOUS CHARGE OF WATER")

(2) METHOD OF BOUWER AND RICE, 1976 (ARTICLE IN VOL. 12, NO.3 OF WRR ENTITLED

"A SLUG TEST FOR DETERMINING HYDRAULIC CONDUCTIVITY OF UNCONFINED AQUIFERS WITH COMPLETELY OR PARTIALLY PENETRATING WELLS")

WELL NO.: 1147

PROJECT NO.: E221-002

SITE LOCATION: WAG-11

EDGE, INC. FIELD INVESTIGATOR: JAMES $W$. CARUTHERS
DATE OF TEST: $9-28-90$

CLIENT: MMES

\section{INPUT DATA ARE:}

INNER CASING DIAMETER $=4.00$ INCHES

INNER SCREEN OR OPEN-HOLE DIAMETER $=4.00$ INCHES

DIAMETER OF DRILLED HOLE $=8.00$ INCHES

LENGTH OF SCREEN OR INTAKE PORTION $=20.00$ FEET

DEPTH FROM STATIC LEVEL TO BOTTOM OF SCREEN $=17.00$ FEET THICKNESS OF SATURATED AQUIFER ZONE $=20.00$ FEET

DEPTH TO STATIC WATER LEVEL BELOW REF. POINT $=14.60$ FEET ESTIMATED POROSITY OF GRAVEL PACK $=.20$

FALLING-HEAD INDEX $=0$ ("1" IF FALLING, "0" IF RISING)

NUMBER OF DEPTH-TIME DATA POINTS = 32

HO WAS COMPUTED FROM INTERCEPT OF PLOT OF LOG(H) VS. TIME

SUCCESSIVE COMPUTED

VALUES FOR HO

(FEET)

.6513

.6559 


\section{HYDRAULIC CONDUCTIVTY CALCULATIONS}

\begin{tabular}{|c|c|c|}
\hline$\left(\operatorname{SEC}^{\text {TIME }}\right)$ & $\begin{array}{l}\text { DEPTH TO WATER } \\
\text { (FEET) }\end{array}$ & $\begin{array}{r}\text { HEAD } \\
\text { (FEET) }\end{array}$ \\
\hline $\begin{array}{r}10.00 \\
20.00 \\
30.00 \\
40.00 \\
50.00 \\
60.00 \\
75.00 \\
90.00 \\
105.00 \\
120.00 \\
150.00 \\
180.00 \\
240.00 \\
300.00 \\
360.00 \\
420.00 \\
480.00\end{array}$ & $\begin{array}{l}13.250 \\
13.500 \\
13.680 \\
13.780 \\
13.880 \\
13.930 \\
13.980 \\
14.040 \\
14.070 \\
14.090 \\
14.110 \\
14.160 \\
14.190 \\
14.200 \\
14.200 \\
14.240 \\
14.240\end{array}$ & $\begin{array}{r}1.350 \\
1.100 \\
.920 \\
.820 \\
.720 \\
.670 \\
.620 \\
.560 \\
.530 \\
.510 \\
.490 \\
.440 \\
.410 \\
.400 \\
.400 \\
.360 \\
.360\end{array}$ \\
\hline $\begin{array}{r}540.00 \\
600.00 \\
720.00 \\
840.00 \\
960.00 \\
1080.00 \\
1200.00 \\
1320.00 \\
1440.00 \\
1560.00 \\
1680.00 \\
1800.00 \\
1920.00 \\
2040.00 \\
2160.00\end{array}$ & $\begin{array}{l}14.260 \\
14.230 \\
14.250 \\
14.280 \\
14.290 \\
14.330 \\
14.340 \\
14.390 \\
14.410 \\
14.430 \\
14.430 \\
14.440 \\
14.400 \\
14.450 \\
14.460\end{array}$ & $\begin{array}{l}.340 \\
.370 \\
.350 \\
.320 \\
.310 \\
.270 \\
.260 \\
.210 \\
.190 \\
.170 \\
.170 \\
.160 \\
.200 \\
.150 \\
.140\end{array}$ \\
\hline
\end{tabular}




\section{Services Co.}

\section{HYDRAULIC CONDUCTIVTY CALCULATIONS}

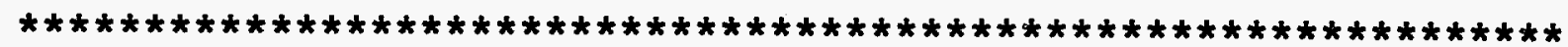
METHOD OF BOUWER AND RICE

COMPUTED RESULTS USING DIAMETER OF DRILLED HOLE:

$$
\begin{aligned}
& \text { PERMEABILITY }=3.01 \mathrm{E}-06 \mathrm{FT} / \mathrm{SEC}=9.18 \mathrm{E}-05 \mathrm{CM} / \mathrm{SEC} \\
& \text { TRANSMISSIVITY }=6.03 \mathrm{E}-05 \mathrm{FT} * 2 / \mathrm{SEC}
\end{aligned}
$$

COMPUTED RESULTS USING DIAMETER OF CASING AND SCREEN:

$$
\begin{aligned}
& \text { PERMEABILITY }=2.25 \mathrm{E}-06 \mathrm{FT} / \mathrm{SEC}=6.86 \mathrm{E}-05 \mathrm{CM} / \mathrm{SEC} \\
& \text { TRANSMISSIVITY }=4.50 \mathrm{E}-05 \mathrm{FT} * 2 / \mathrm{SEC}
\end{aligned}
$$


ERC / EDGE

Environmental

and Energy

WELL No. 1147

Services Co.

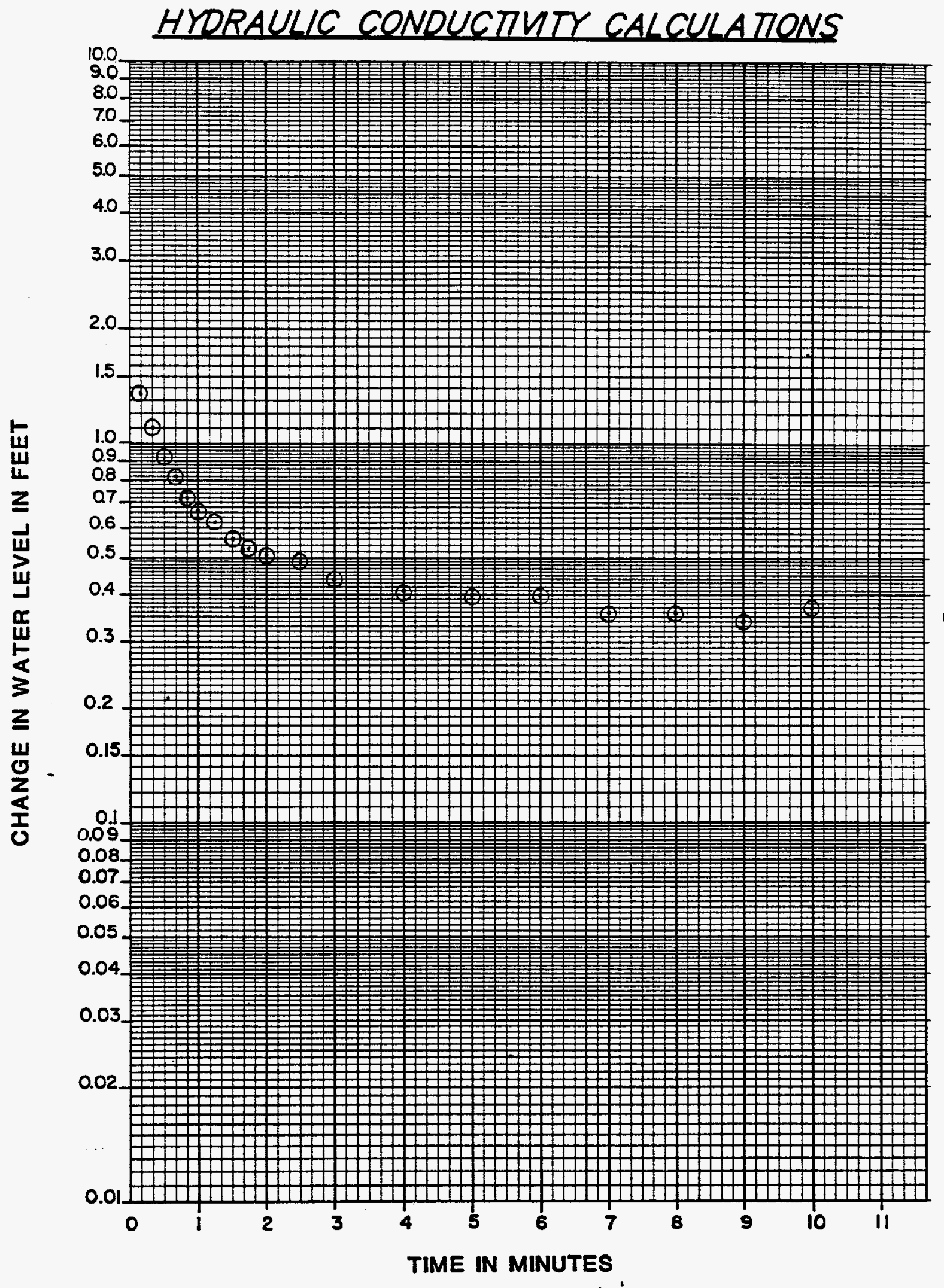

PACE 20 of 21. 


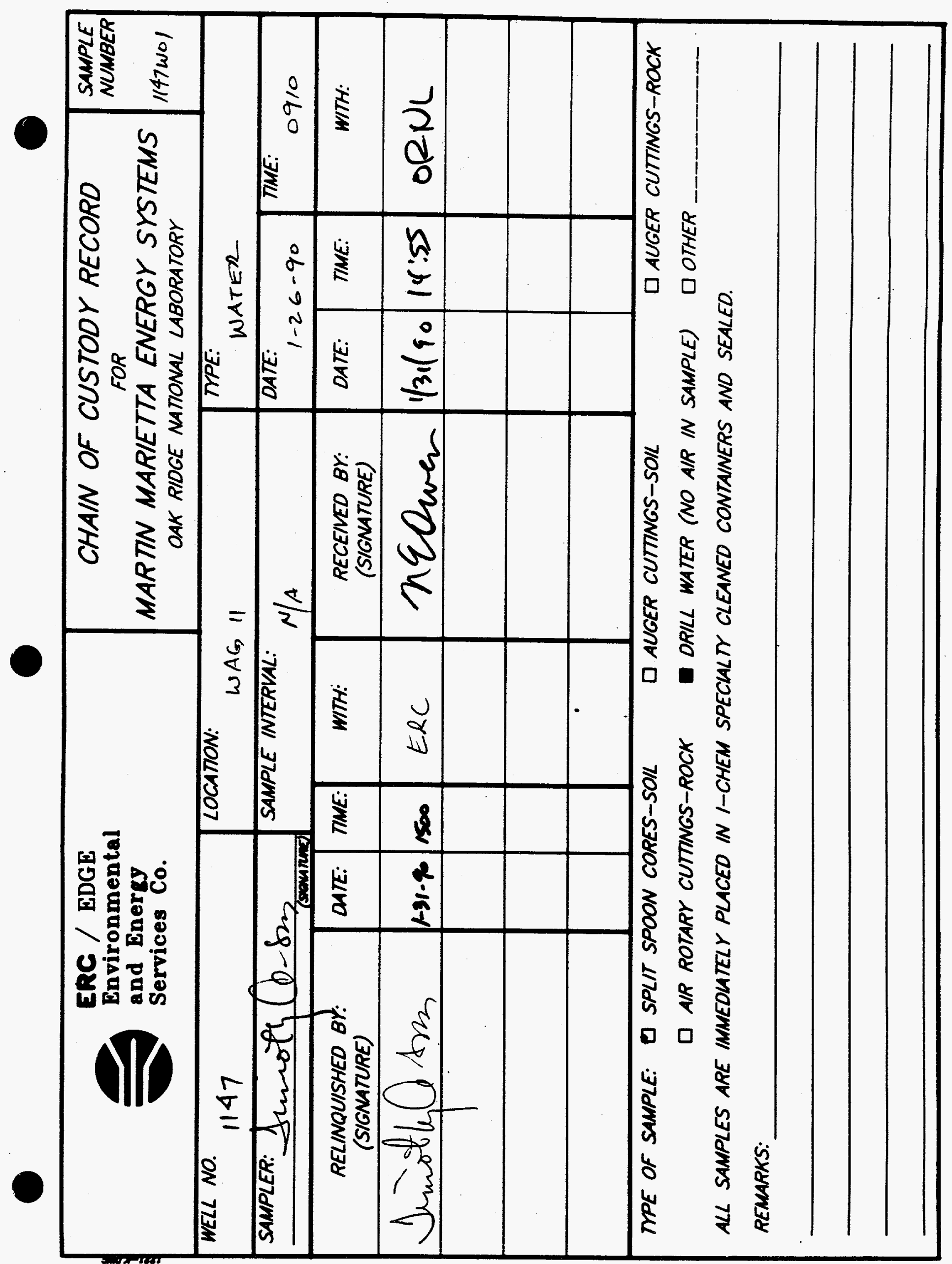


Appendix B

Operating Instructions for Handling Water and Cuttings from Well Drilling and Development of Groundwater Quality Monitoring Wells 


\section{OPERATING INSTROCTIONS FOR HANDLING CUTTINGS AND WATER FROM EROM VELL DRILIINE AND DEVELOPLENT OR THE GROUNDWATER QOALITY GONITORING WELLS}

Prepared by

J. A. Greene 


\section{PROCEDURE REVIEW AND APPROVAL Form}

\section{Environmental and Health Protection Division}

Operating Instructions for Handing Cuteings and hater from

Procedure Tille hell Drilling and Development of the Groundwater Gualitv

Procedure No. Monitoring Wells

Author

REVIEW AND APPROVALAt a minimum. procedures are approved by the manager of the implementing unit end the nexi nigher level mansoer. SOP must be reviewed by OA stall to asure Inat oA requlremento are mel and to verlly inat appllcable standerda are apecilled. slenatures of the epprovers wUST appear on the llret pepe of esech approved procedure. The requited approvere and the OA revlewer muot elon below. Approved by:
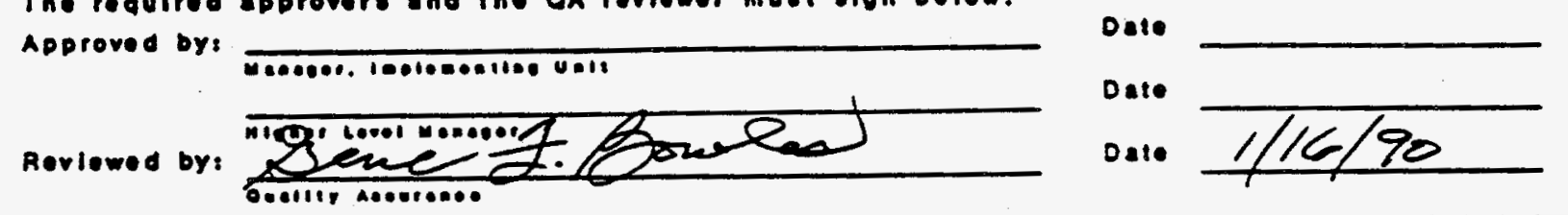

In the epaces below indleafe sdditlonal forlewe (R) or approvals (A). All reviewers ond epprovere muat slon and date thle torm before the procedure can bo llnally approved. if more than one prooeudre is belng revtewed, attach list.

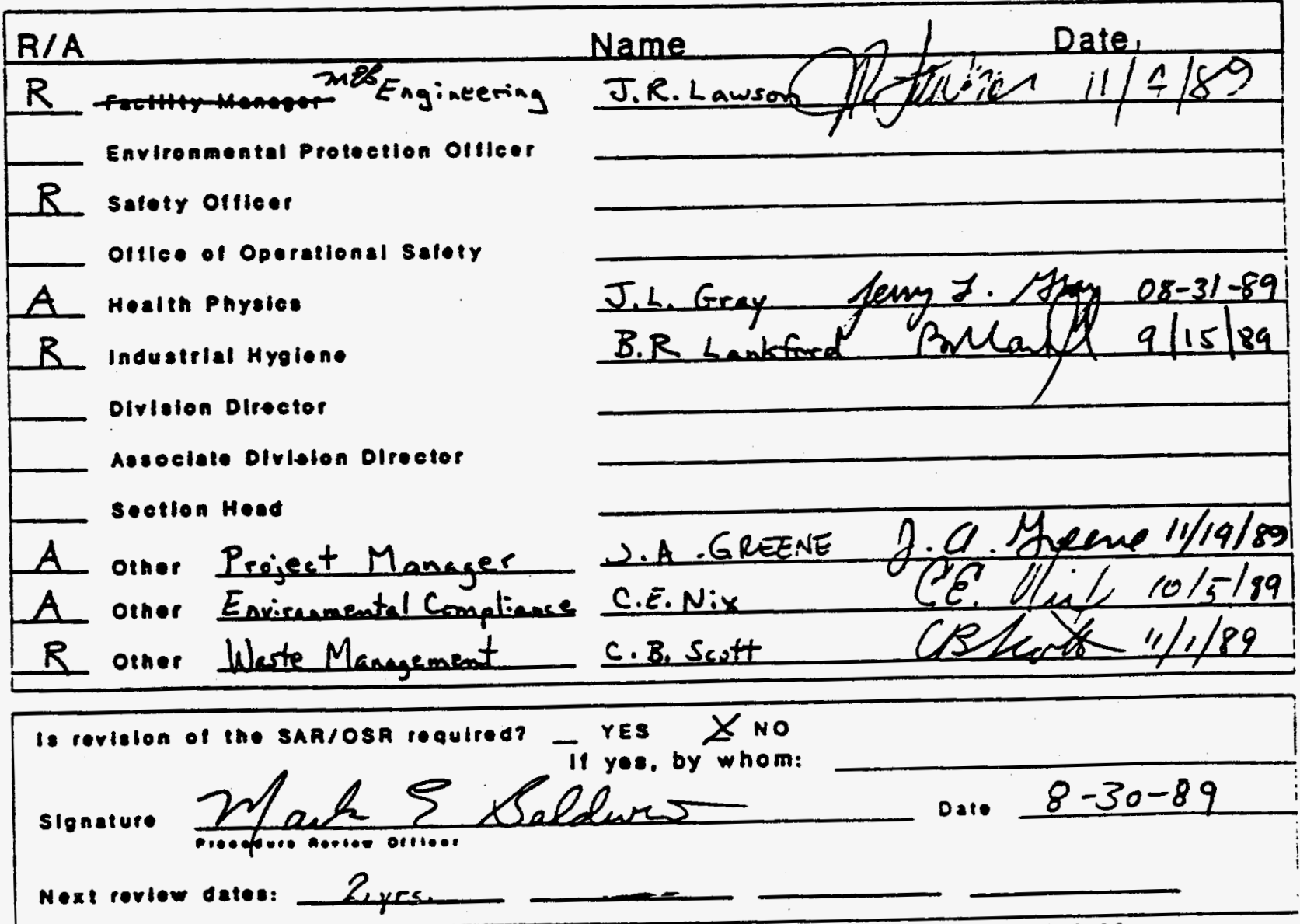

forwerd completed cooy of thls lorm to ine division on office. $1500 \mathrm{~N}$. MS-6186. 


\section{OPERATING INSTRUCTIONS FOR HANDLING CUTTINGS AND WATER FROM FROM WELL DRILLING AND DEVELOPMENT OF THE GROUNDWATER QUALITY MONITORING WELLS}

\subsection{PURPOSE}

The purpose of this document is to cite the steps that are followed to handle water and soil produced during the installation and development of wells.

\subsection{SCOPE}

This document applies to well drilling and development associated with the Groundwater Quality Monitoring Wells Installation Program at Oak Ridge National Laboratory.

\subsection{REFERENCE}

Health, Safety, and Environmental Protection Procedures for Excavating Operations, ORNL/M-116/Rl, Oak Ridge National Laboratory, March 3, 1988.

\subsection{DEFINITIONS}

Well Ratings. Ratings assigned during the excavation permit cycle by Radiation Protection (RP) and Industrial Hygiene (IH) to indicate the probability of encountering radioactive and chemical contamination, respectively. These ratings are based on historical information or from previous drilling or excavation activity. The ratings are marked on the excavation permits. (RP ratings on permits may sometimes be called "HP" for "Health Physics." The two designations are interchangeable.) Protective measures required for the three categories are stated in Table 1, "Excavation-classification categories," ORNL/M-116/R1. The categories for soil handling are stated in Appendix B, 'Radiological Soil Handling Criteria,"' in ORNL/M-116/R1.

RP Category 1. A rating assigned by RP which indicates that the probability of encountering radioactive contamination is low and that intermittent monitoring is required by $R P$.

IH Category 1. A rating assigned by IH which indicates that the probability of encountering chemical contamination (1.e., organics) is low and that monitoring is not required by IH. An IH and/or Environmental Monitoring and Compliance (EM\&C) representative will be called in any time chemical or hazardous contamination is suspected.

RP Category 2. A rating assigned by RP which indicates that the probability of encountering radioactive contamination is moderate and that continuous monitoring is required. The RP representative will determine the necessary level of protective clothing to be worn.

IH Category 2. A rating assigned by Ill which indicates that the probability of encountering chemical contamination is moderate and that respirators must be on-site and ready for use by the workers when 
indicated by the IH or RP representative on-site. Location will be checked periodically with an IH field instrument, such as a Photovac or Organic Vapor Organizer (OVA).

RP Category 3. A rating assigned by $R P$ which indicates that there is a high probability of encountering radioactive contamination. Therefore, continuous monitoring by an RP representative is required, and protective clothing must be worn. In addition to the training listed above, workers must have successfully completed the Category 3 Driller Training course that is administered by Environmental and Health Protection Division (E\&HP) personnel.

IH Category 3. A rating assigned by IH which requires the workers to wear respirators as a minimum. Additional protection deemed appropriate by IH will be designated for each location. Continuous monitoring by IH personnel is required.

Training Requirements. Training requirements for workers include the Basic Radiation Training administered by E\&HP personnel and the $40 \mathrm{~h}$ of training required by the Superfund Amendment Reauthorization Act (SARA) through a company-approved course. There is an additional training course required for Category 3 drilling.

Air rotary containment box. A box specially designed to contain the cuttings and water that are blown from the borehole during air rotary drilling. The box is equipped with a high-efficiency particulate air (HEPA) filter to prevent particles that possibly contain contaminants from being dispersed into the air. Air rotary drilling is generally used only for drilling into bedrock.

Auger pan. A metal catch pan with a hole cut in the middle. The pan surrounds the borehole and contains soil cuttings as they are augered up.

Proper On-Site Disposal. Disposal of noncontaminated soil and water produced from work on a well at a location near the well that is not openly visible to the public and has no risk of causing erosion or direct discharge into a stream. The construction engineer (CE) will indicate to the drillers which areas are acceptable for on-site disposal. The $\mathrm{pH}$ will have been checked and adjusted to the 5-to.9 range before releasing. This precise definition is intended wherever this term is used in this procedure.

Proper Contaminated Waste Disposal. Generally, radioactively contaminated soil will be packaged in drums and tagged by the RP representative for disposal by ORNL Waste Operations. However. Category-2-level soil may be used on site as backfill in remote areas when covered by $1 \mathrm{ft}$ of noncontaminated soil as stipulated in ORNL/M$116 / R 1$. The CE will specify to the drillers when a well location has been approved by EM\&C for on-site dispesal of contaminated soll. This definition is intended wherever this term is used in this procedure. 
Temporary Drilling Equipment Cleaning Fac1lity. An outdoor area located in Melton Valley for steam cleaning of drill rigs and associated equipment, referred to as the steam cleaning area.

Containment Box Holding Pit. A lined pit at the Temporary Drilling Equipment Cleaning Facility. The contents of the pit will be sampled and tested for gross alpha, gross beta, pH, and tritium*, before being released through a silt fence. Contents that have a potential for containing hazardous materials (i.e., IH Category 2 and 3 locations) will have been checked with an IH field instrument before being released into the pit.)

Steam Cleaning Pits. Two lined pits at the Temporary Drilling Equipment Cleaning Facility that collect runoff from the steam cleaning operations. The contents of the pits will be sampled and tested for gross alpha, gross beta, pH, and tritium*, before being released through a silt fence. Contents that have a potential for containing hazardous materials (i.e., IH Category 2 and 3 locations) will have been checked with an IH field instrument before being released into the pit.)

\subsection{RESPONSIBILITIES}

5.1 Radiation Protection Personnel monitor and determine the presence of detectable radioactive contamination in drill cuttings during well-drilling activities. They provide guidance to ensure that exposures to the workers, public, and environment are kept as low as reasonably achievable. They also provide radiation monitoring during the precursory cleaning by the drillers.

5.2 Well-Drilling Personnel perform well drilling and completion activities. They package soil and water in appropriate containers and transport it, if necessary; perform precursory cleaning of low-level contaninated equipment; and perform cleaning of equipment between the drilling of each well.

5.3 EDGe Hydrogeologists observe all crucial well installation activities and record data for all boreholes drilled. They do a visual inspection of the cuttings produced during augering and note any unususl occurrences and obvious deleterious material encountered during the drilling process. They check the cuttings and water with a Photovac or OVA or similar instrument and check $\mathrm{pH}$ of water when necessary.

5.4 Construction Engineer serves as the field contact and provides guidance to the drillers during field activities.

\subsection{PROCEDURE}

6.1 EXPLANATION OF THE WELL RATING SYSTEM

Each well is assigned a rating by RP and IH before drilling begins. Because additional information is gained during drilling. 
well ratings may be changed by $R P$ and $I H$ as the work progresses. A lower RP Category rating will be changed to a Category 3 rating upon encountering radioactive contamination within the Category 3 range defined in ORNL/M-116/R1. Likewise, an IH Category 3 may result if chemical contamination is detected in a well with a lower rating. The RP and/or IH representative on site will notify the on-site personnel when conditions warrant a rating change. Any additional actions or modifications in protective clothing required by the rating change will be executed at that time. The change will be documented immediately by the on-site hydrogeologist in the well data package and as soon as possible by the RP and/or IH representative by a signed written statement stating the well number, the old and new ratings, and the rationale supporting the change. The statement will be sent by the RP and/or IH representative to the Construction Engineer (CE) for filing with the original excavation permit. A copy will be sent to the RAP Well Installation Manager by the CE.

A well category also may be changed from a higher rating to a lower rating. For example, if no contamination is encountered while drilling a Caregory 2 or 3 well, it may be changed to a lower rating after drilling to a certain depth or for development purposes, depending on the history of the area. The documentation procedure stated above for an increase in rating must also be followed for a decrease in rating.

\subsection{CATEGORY 1 WELLS (RP OR IH)}

\subsubsection{Category 1 Drilling}

\subsubsection{Category 1 Auger Cuttings}

a. Auger cuttings will be collected in a catch pan.

b. An RP representative will scan the cuttings intermittently to check for radioactive contamination. Cuttings will be inspected for any unusual discoloration or odor by the hydrogeologist.

c. If there is no contamination detected, proper on-site disposal or disposal at the steam cleaning area will be done.

\subsubsection{Category 1 Air Rotary Drilling}

a. Cuttings will be collected in a containment box.

b. When the containment box is full, one of the following will be done to empty cuttings and/or decant water from the containment box:

(1) proper on-site disposal. 
(2) disposal at the containment box holding pit.

6.2.2 Category 1 Well Development

6.2.2.1 Water removed from the well will be contained in drums.

6.2.2.2 The pH of the water will be measured and will be adjusted to be between $S$ and 9 by the CE if it is above or below that range.

6.2.2.3 Drums of water will be discarded by proper on-site disposal or disposal at the steam cleaning area will be done.

\subsection{CATEGORY 2 WELLS (RP AND IH)}

\subsubsection{Category 2 Drilling}

6.3.1.1 Category 2 Auger Cuttings

a. Auger cuttings will be collected in a catch pan.

b. An RP representative will scan the cuttings continuously to check for radioactive contamination. Cuttings will be inspected for any unusual discoloration or odor and tested with a Photovac or OVA by the hydrogeologist for presence of RCRA materials.

c. If there is no contamination detected, proper on-site disposal or disposal at the steam cleaning area will be done.

d. Cuttings will be contained in drums if contamination is detected. Proper disposal will be arranged by Martin Marietta Energy Systems through Waste Operations.

\subsubsection{Category 2 Air Rotary Drilling}

a. Rock cuttings and drill water will be collected in a containnent box.

b. When the containment box becomes full, the RP representative will perform a wet towel smear to detect the presence of radioactive contamination. An inspection for unusual discoloration or odor and tests with an OVA will be conducted for the presence of RCRA materials by the hydrogeologist. 
c. If no contamination is detected, one of the following will be done to empty cuttings and/or decant water from the containment box:

(1) proper on-site disposal.

(2) disposal at the containment box holding pit.

d. If contamination is detected by the tests, arrangements will be made by Martín Marietta Energy Systems through Waste Operations to properly dispose of the water. Further laboratory testing of the box contents may be done.

\subsubsection{Category 2 Development}

6.3.2.1 Water removed from the well will be contained in drums.

6.3.2.2 When the drums are ready to be emptied, the RP representative will perform a wet towel smear to detect the presence of radioactive contamination. An inspection for unusual discoloration or odor and tests with an OVA will be conducted for presence of RCRA materials by the hydrogeologist. The $\mathrm{pH}$ will be adjusted if necessary.

6.3.2.3 If no contamination is detected, the water will be discarded by proper on-site disposal or disposal at the steam cleaning area will be done.

6.3.2.4 If contamination is detected by the tests, arrangements will be made by Martin Marietca Energy Systems to properly dispose of the water. Further laboratory testing may be done.

\subsection{CATEGORY 3 WELLS (RP AND IH)}

\subsubsection{Category 3 Drilling}

\subsubsection{Category 3 Augering}

a. When a well is classifled as an RP Category 3 or an IH Category 3, continuous monitoring will be required by $R P$ and $I H$. Wearing of respirators will be required. Cuttings will be inspected for any unusual discoloration or odor. Tests for chemical contamination (i.e., organics) will be performed with IH field instruments by an IH representative for IH Category 3 wells:- Specially trained personnel will be required to do the drilling. 
b. If no contamination is detected by $R P$ or IH while augering through soil to bedrock, a rating may be changed by RP or IH to a Category 2 depending on the depth, the type of contamination expected, and the history of the area.

c. If contamination is detected during augering, cuttings will be drummed. Proper disposal of all cuttings and water will be arranged by Martin Marietta Energy Systems.

\subsubsection{Category 3 Air Rotary Drilling}

a. Rock cuttings and drill water will be collected in a containment box.

b. When the containment box becomes filled with water and/or cuttings, a sample will be collected by EM\&C and will be tested by the Analytical Chemistry Division for gross alpha, gross beta, tritium*, for an RP Category 3. If it is an IH Category 3, the IH representative on-site will determine which (if any) laboratory testing is necessary for chemical contaminants.

c. Proper disposition of the containment box contents will be decided by consensus of E\&HP, the IH or RP representative, EM\&C, and the CE, based on the results from Analytical Chemistry Division of the above tests.

\subsubsection{Category 3 Development}

6.4.2.1 Water pumped from Category 3 wells will be contained in drums. Samples will be collected by EM\&C and will be tested by Analytical Chemistry Division for gross alpha, gross beta, tritium*, and pH. It will be tested with IH field instruments by IH representatives for the presence of RCRA materials.

6.4.2.2 A decision based on the test results will be made between E\&HP and Engineering whether to continue development.

\subsection{BOREHOLE CLEANING}

When sludge and water have accumulated in the bottoms of boreholes drilled in soil, the boreholes must be cleaned out prior to setting casings. A decision based on the location of the borehole and its rating will be made between the RP and/or IH representatives whether the sludge and water from the borehole must be contained in a drum. Water and sludge from a Category 2 well will be drummed, and a wet towel smear will be done by RP to 
determine proper disposal of the drum contents. Laboratory testing of the drum contents for gross alpha, gross beta, tritium*, and $\mathrm{pH}$ will be done if recommended by the RP or IH representative. Water and sludge removed from an RP Category 3 well will be drumed, and laboratory testing will be done for gross alpha, gross beta, tritium*, and pH. EM\&C will be consulted to determine proper disposal based on the test results. Further laboratory testing to determine actual contaminants will be done if recommended by EM\&C.

-Testing for tritium will be done for wells located in areas where tritium contamination is suspected. This decision will be made between RP and EMte. 


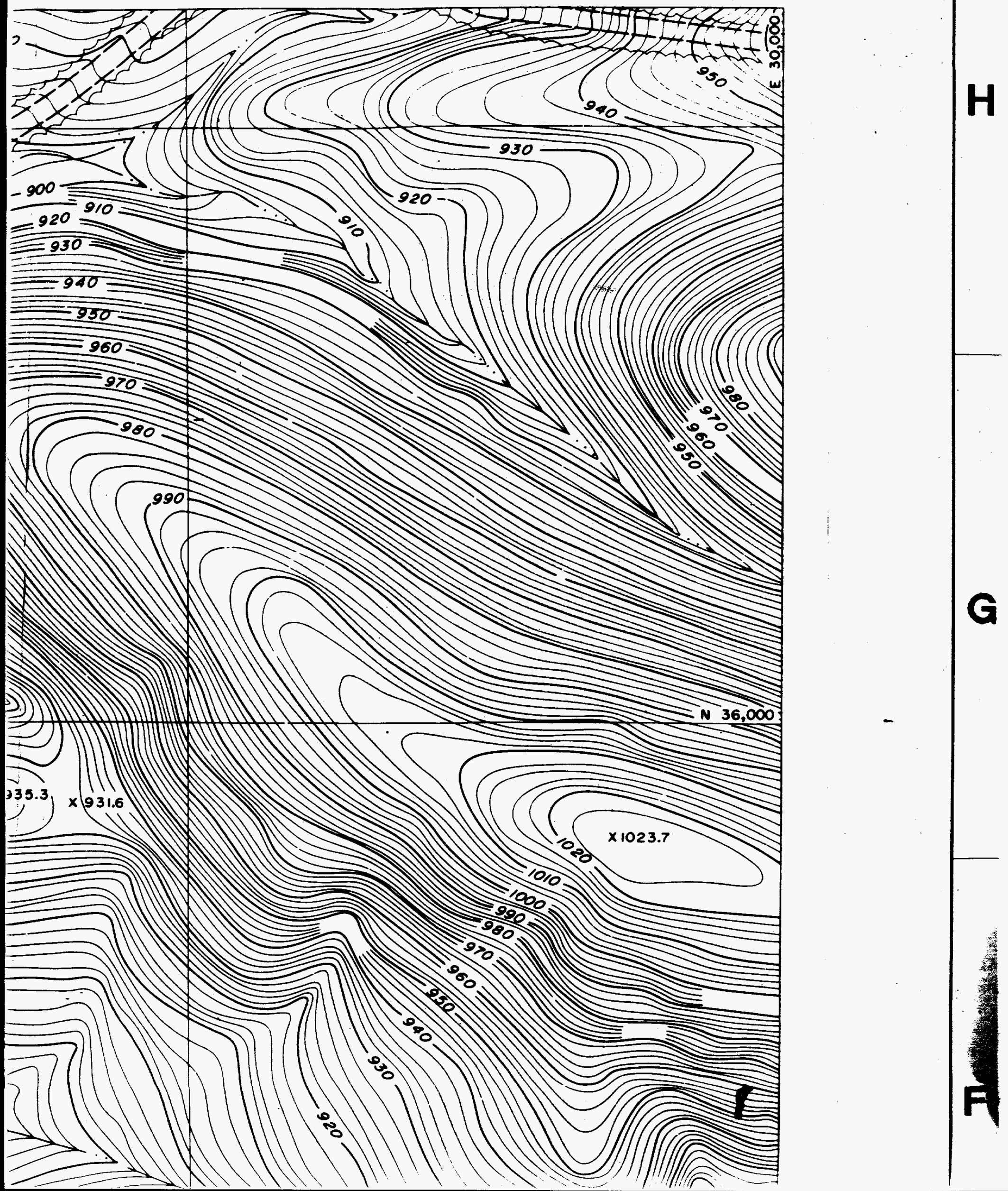




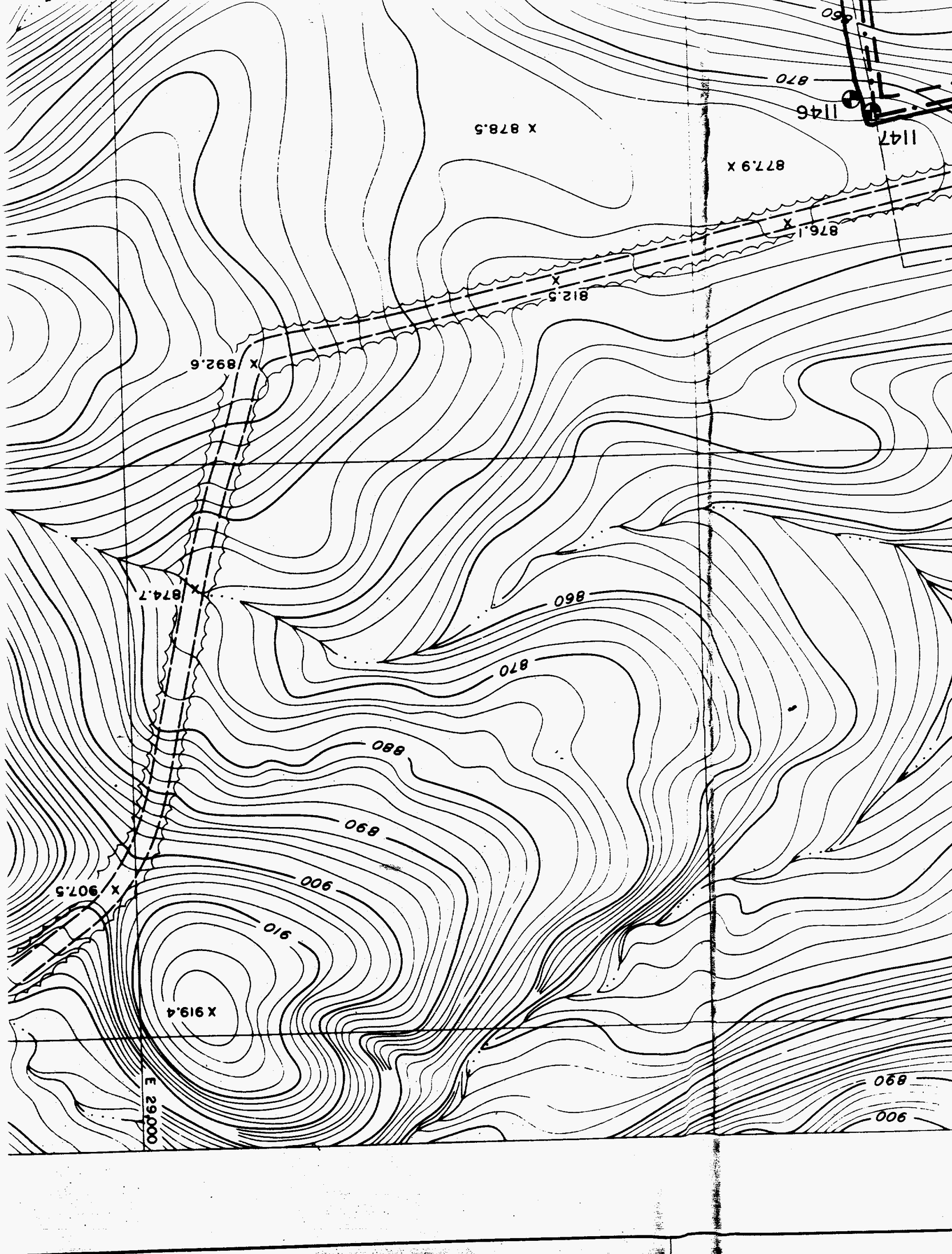




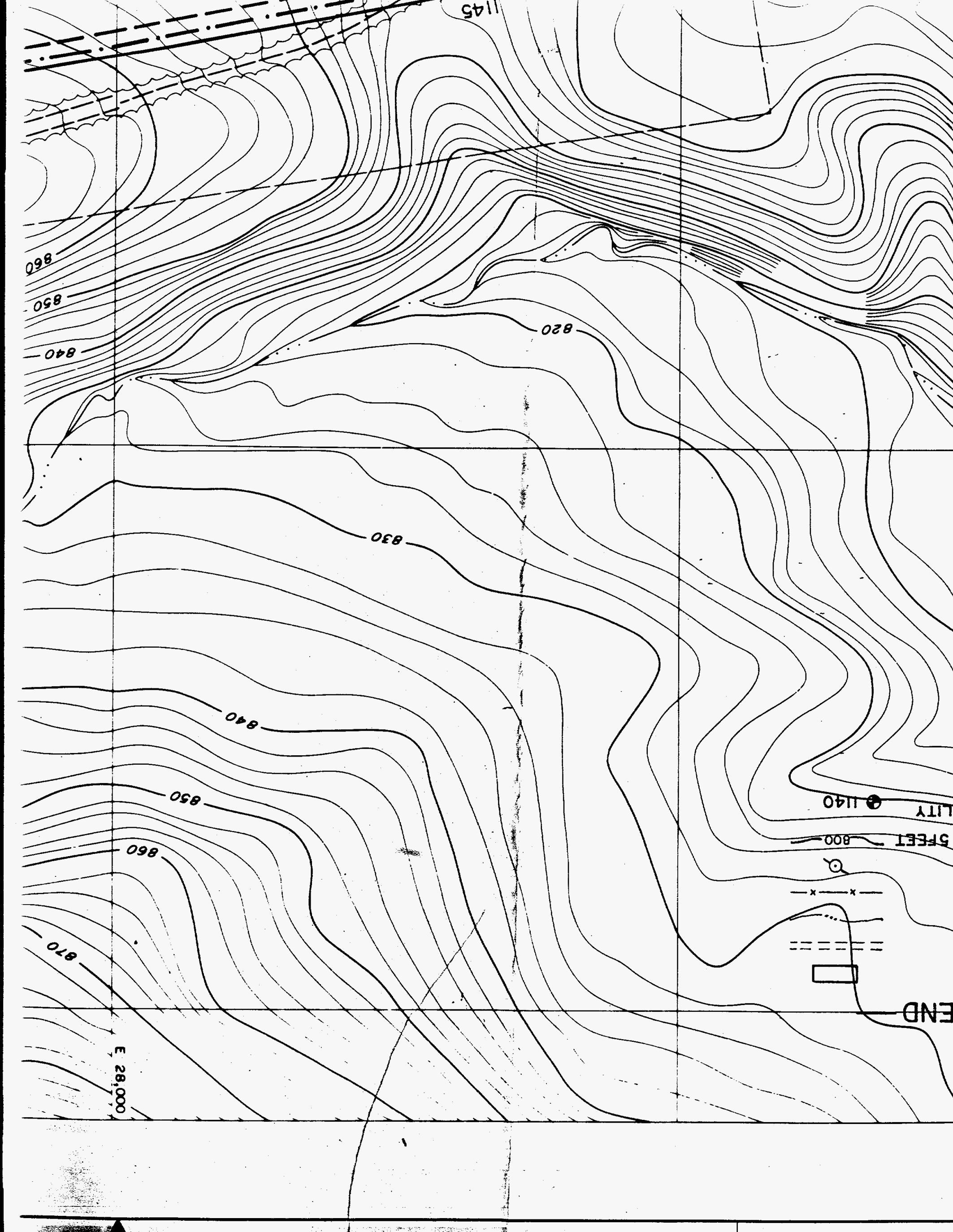




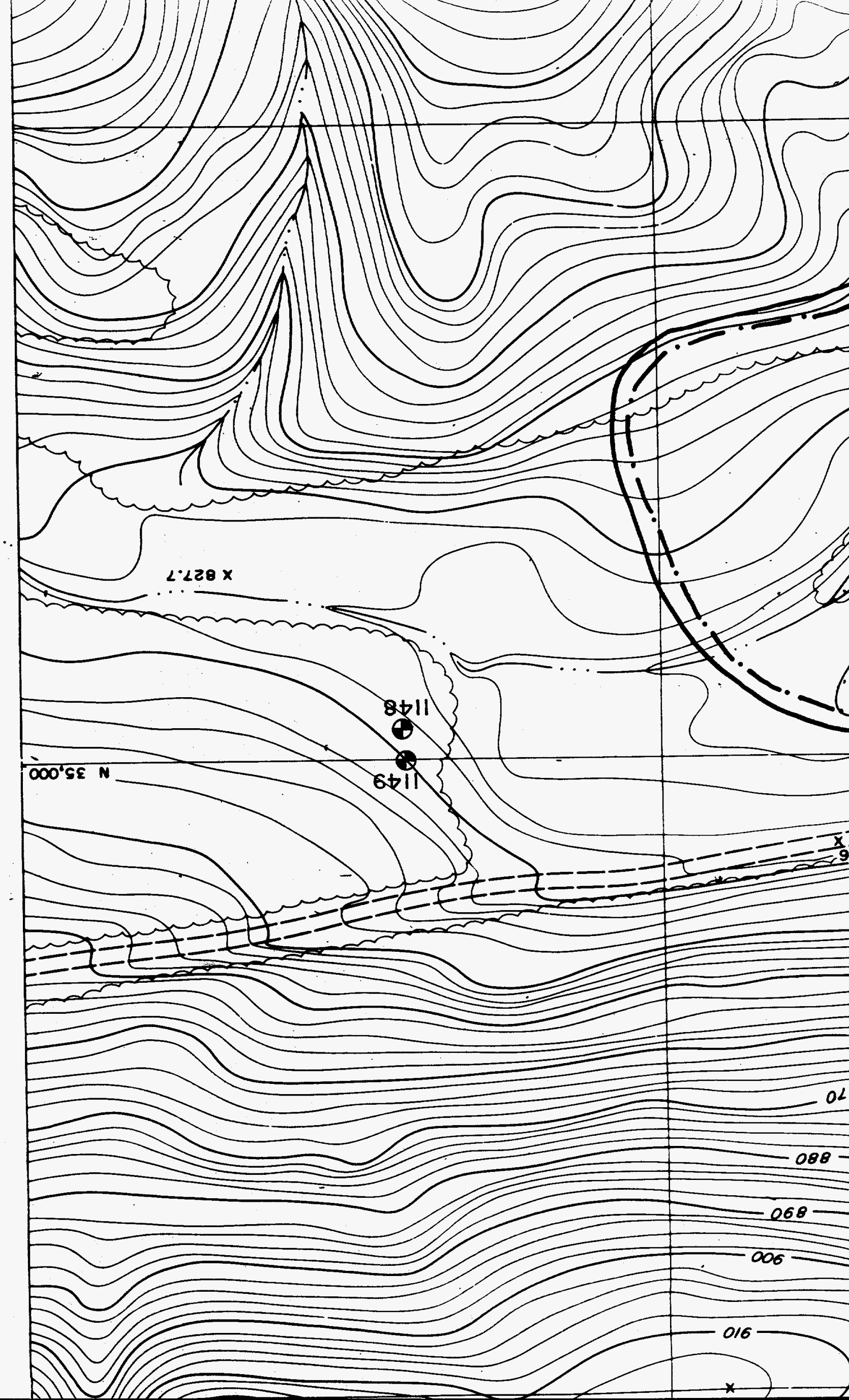




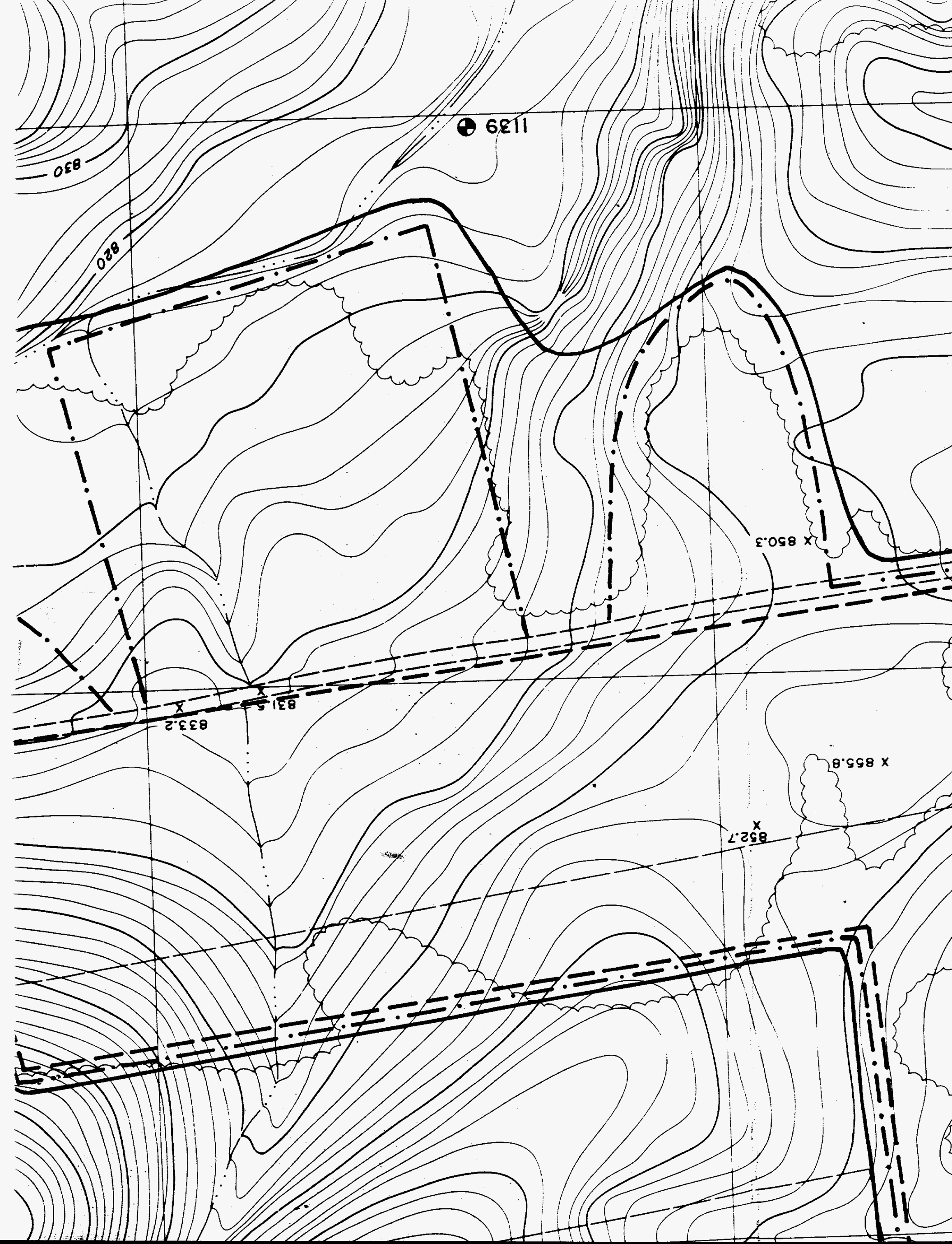




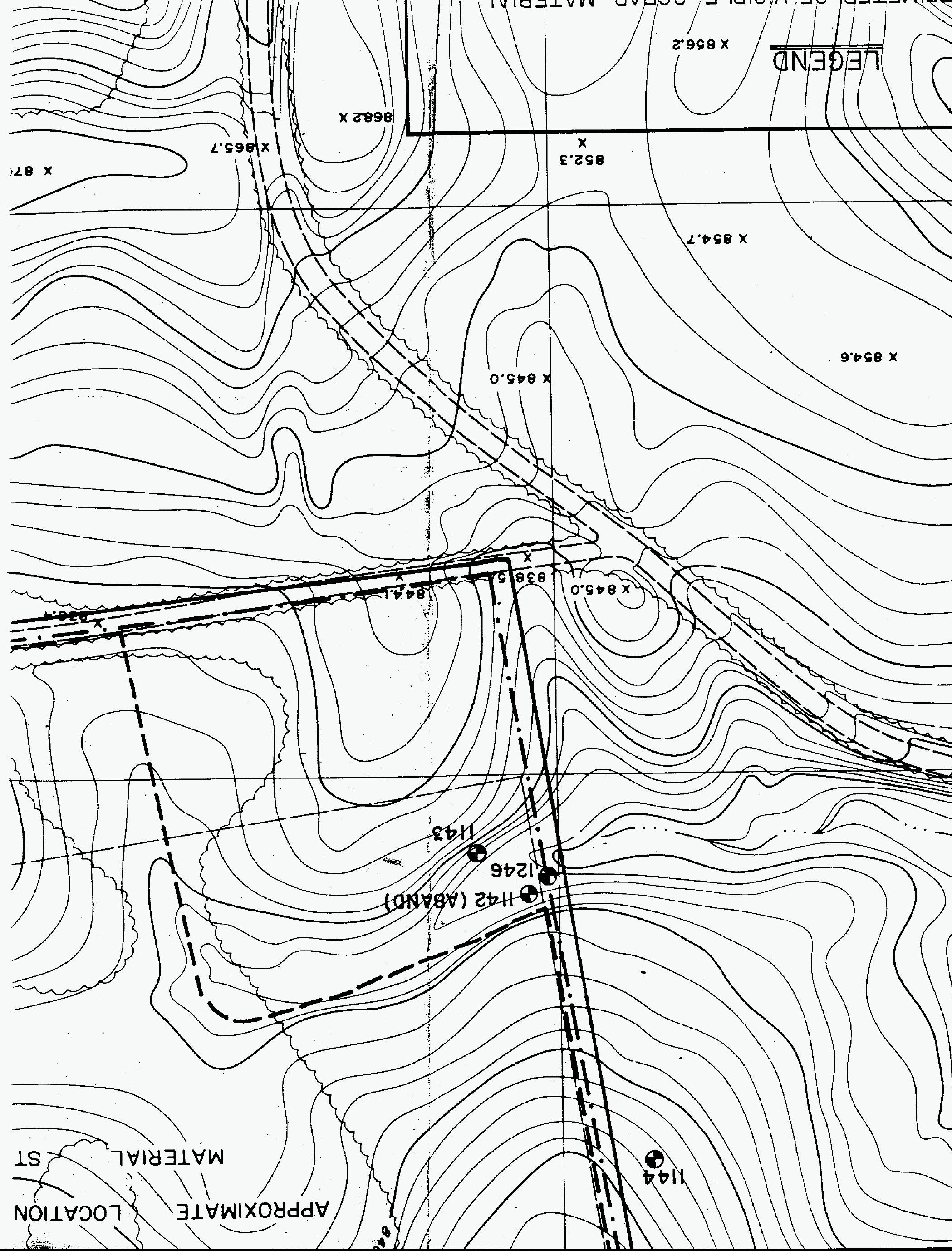




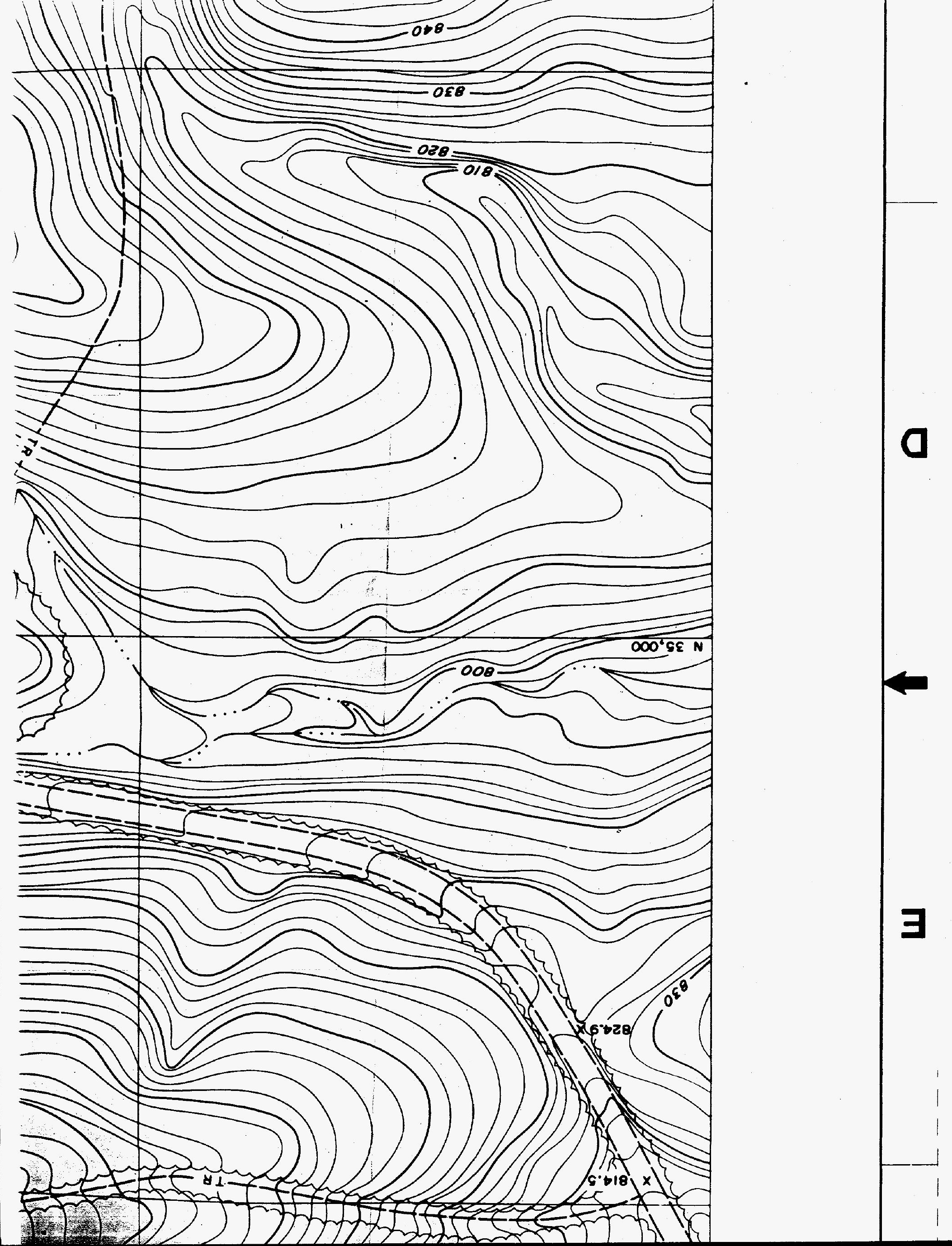




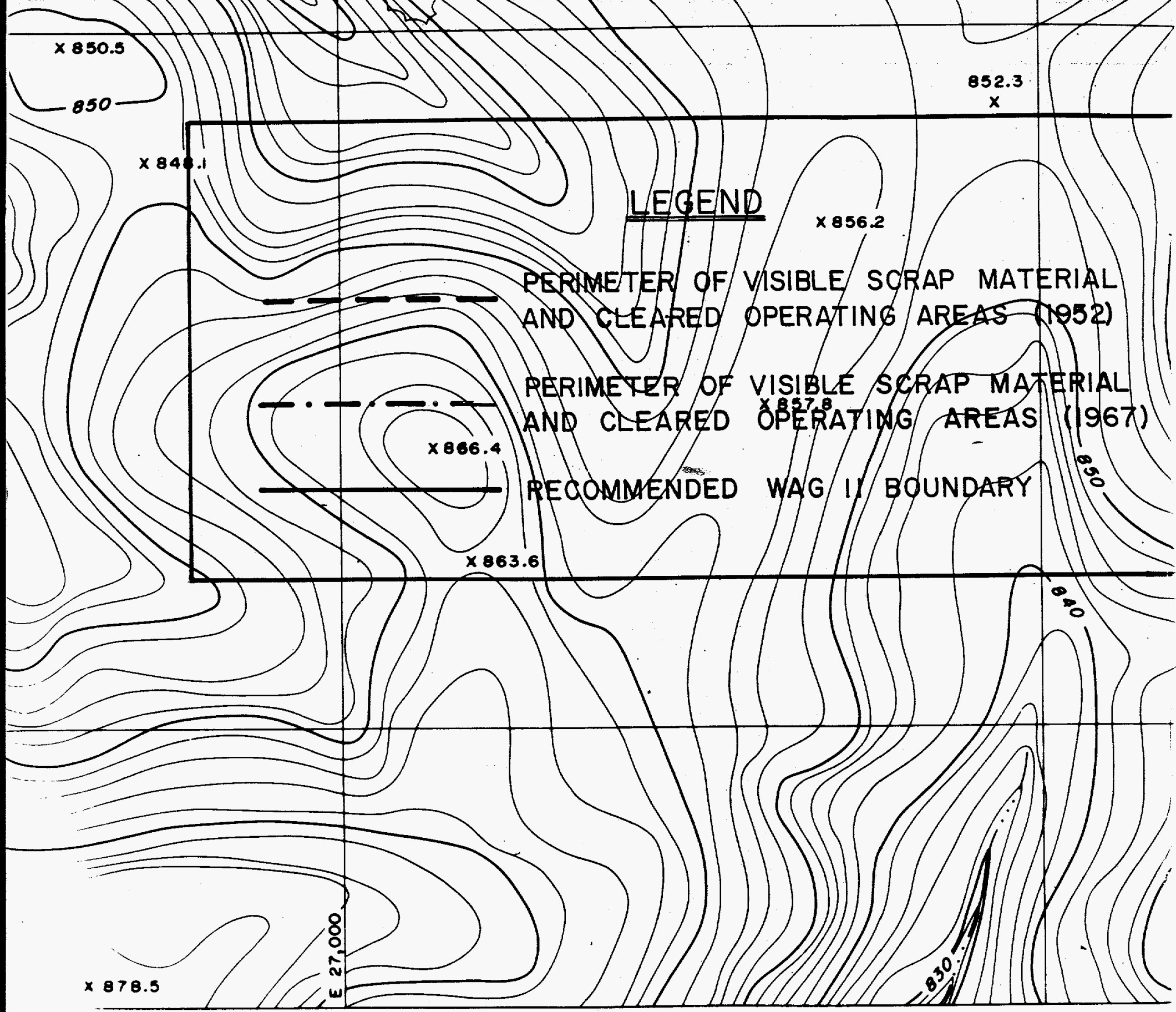




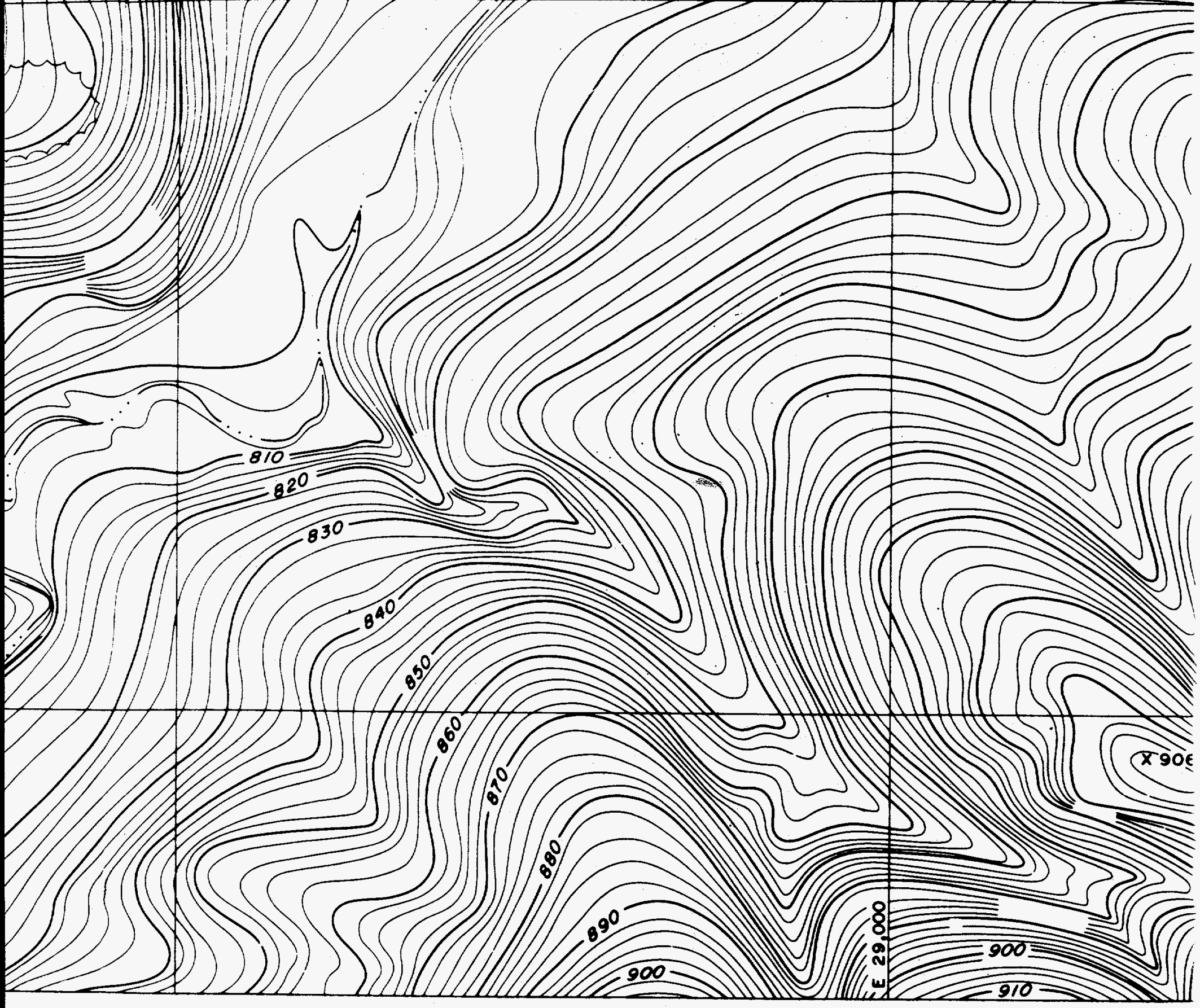

TOLERANCES

UNLESS OTHERWISE SPECIFI: FRACTIONS

$X X$ DECIMALS

$X X X$ DECIMALS

ANGLES

FINISH

ADAMS CRAFT HERZ WALKE

\begin{tabular}{|l|l|l|l|l|l|}
\hline & & & & & \\
\hline
\end{tabular}




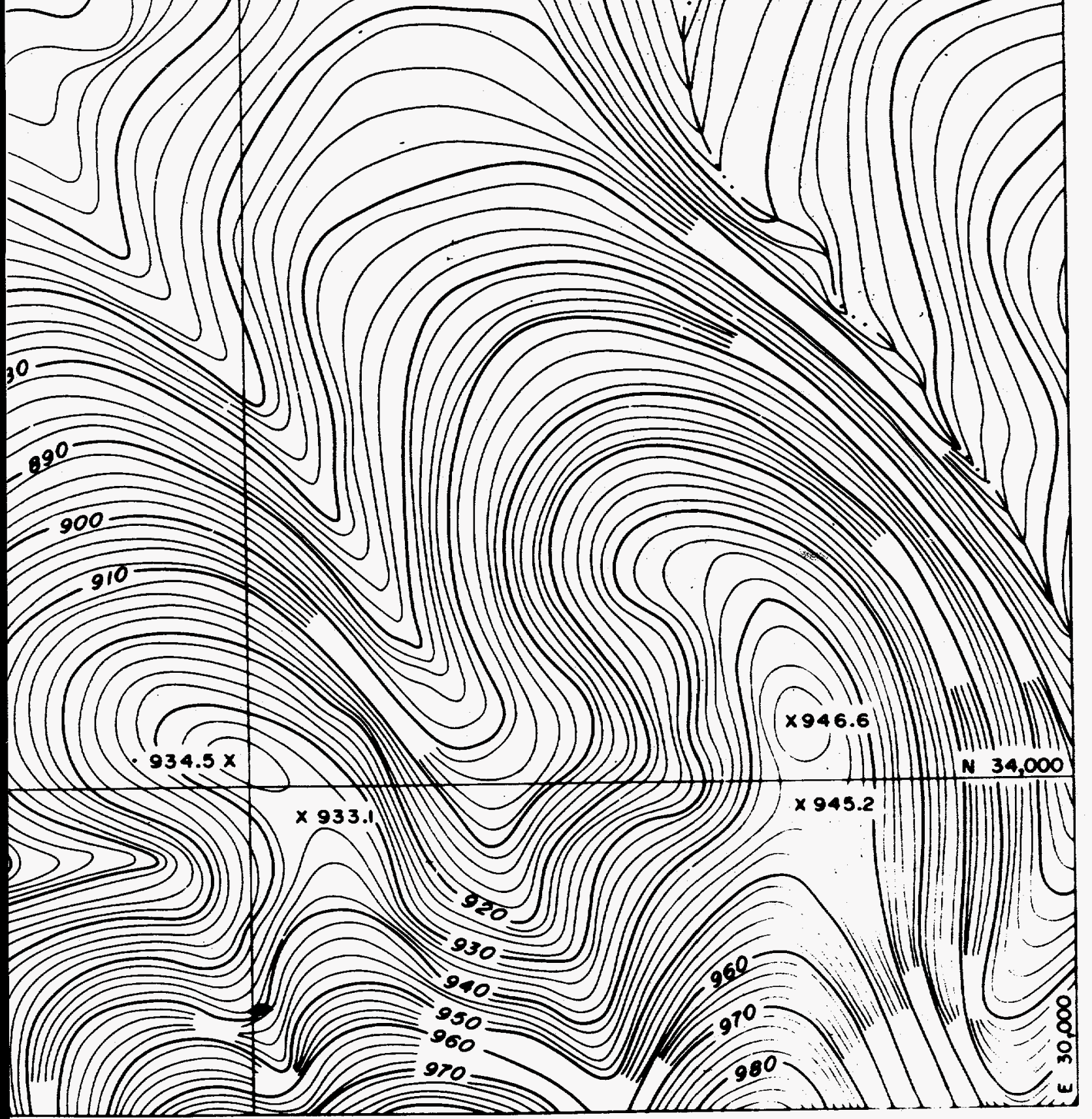

NOTE: Y-I2 COORDINATE GRID SYSTEM

\begin{tabular}{|c|c|c|c|c|c|c|c|c|}
\hline AMS & $4-1-9 \mid$ & \multirow{3}{*}{\multicolumn{7}{|c|}{ 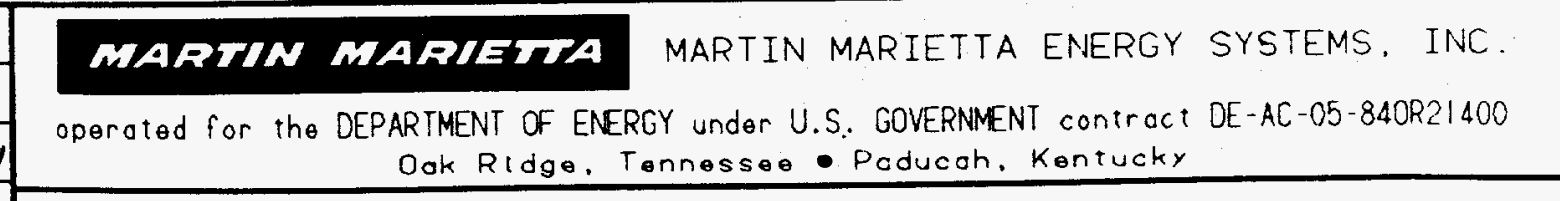 }} \\
\hline AMS & $4-|-9|$ & & & & & & & \\
\hline$\frac{\operatorname{lgm}}{4}$ & $\begin{array}{l}8 / 22 / 91 \\
8 / 22191\end{array}$ & & & & & & & \\
\hline \multirow{5}{*}{ l. } & & \multirow{2}{*}{\multicolumn{7}{|c|}{$\begin{array}{c}\text { GROUNDWATER QUALITY MONITORING WELLS } \\
\text { WAG II LOCATION MAP } \\
\text { WHITEWING SCRAPYARD }\end{array}$}} \\
\hline & $8 / 22 / 91$ & & & & & & & \\
\hline & & $W A G$ & & $10 \mathrm{~N}$ & WELL & 00 & MAP & $\mathrm{MPPE}^{\mathrm{TY}}$ \\
\hline & & \begin{tabular}{l|l}
48 & 49 \\
$\mathbf{C}$ & $\mathbf{M}$
\end{tabular} & $\frac{50}{T}$ & $\begin{array}{l}P L A N T \\
Y-12\end{array}$ & $\underline{B L D G}$ & $\underline{F L}$ & SHEET 1 OF 1 & $U^{C L A S}$ \\
\hline & DATE & $\begin{array}{l}\text { SCALE } \\
I^{\prime \prime}=100^{\prime}\end{array}$ & \multicolumn{2}{|c|}{ PKX81202 } & \multicolumn{3}{|c|}{ C $3 E 020004 A_{123}$} & $\begin{array}{l}\text { REV } \\
0\end{array}$ \\
\hline
\end{tabular}




\section{DISTRIBUTION}

1. F. P. Baxter

2. C. A. Bednarz

3. H. L. Boston

4. T. A. Early

5. M. L. Ebers

6. R. H. Ketelle

7-9. D. M. Matteo

10. J. A. Mortimore

11-12. P. T. Owen

13. P. A. Schrandt

14. M. M. Stevens

15. P. S. Wood

16-18. ORNL ER Document Management Center

19. ORNL Patent Section

20-22. Central ER Document Management Center

23. Laboratory Records Department

24. Central Research Library

25. Office of Assistant Manager for Energy Research and Development, DOE Oak Ridge Operations Office, P.O. Box 2001, Oak Ridge, TN 37831-8600

26-27. Office of Scientific and Technical Information, P.O. Box 62, Oak Ridge, TN 37831 